\title{
The East Greenland rifted volcanic margin
}

C. Kent Brooks 


\section{Geological Survey of Denmark and Greenland Bulletin 24}

\section{Keywords}

East Greenland, North Atlantic, rifted volcanic margin, large igneous province, LIP, Palaeogene, basalt, syenite, nephelinite, carbonatite, uplift.

\section{Cover}

Sundown over the nunataks in the Main Basalts (Skrænterne Fm) to the south of Scoresby Sund. Camped on the glacier, the 1965 Oxford University East Greenland Expedition travelled and collected from this area on foot, manhauling equipment on the sledge to the left. The expedition results were published in Fawcett et al. (1973).

\section{Frontispiece: facing page}

Mountains of horizontally layered basalt flows rising to about $2000 \mathrm{~m}$ on the south side of Scoresby Sund. Typical trap topography as found throughout most of the Kangerlussuaq-Scoresby Sund inland area.

Chief editor of this series: Adam A. Garde

Editorial board of this series: John A. Korstgård, Department of Geoscience, Aarhus University; Minik Rosing, Geological Museum, University of Copenhagen; Finn Surlyk, Department of Geography and Geology, University of Copenhagen

Scientific editor of this volume: Adam A. Garde Editorial secretaries: Jane Holst and Esben W. Glendal

Referees: Dennis K. Bird (USA) and Christian Tegner (DK)

Illustrations: Eva Melskens with contributions from Adam A. Garde

Digital photographic work: Benny Schark

Graphic production: Kristian A. Rasmussen

Printers: Rosendahls - Schultz Grafisk A/S, Albertslund, Denmark

Manuscript received: 1 March 2011

Final version approved: 20 September 2011

Printed: 22 December 2011

ISSN 1604-8156

ISBN 978-87-7871-322-3

\section{Citation of the name of this series}

It is recommended that the name of this series is cited in full, viz. Geological Survey of Denmark and Greenland Bulletin. If abbreviation of this volume is necessary, the following form is suggested: Geol. Surv. Den. Green. Bull. 24, 96 pp.

\section{Available from}

Geological Survey of Denmark and Greenland (GEUS)

Øster Voldgade 10, DK-1350 Copenhagen K, Denmark

Phone: +4538 142000, fax: +45381420 50, e-mail:geus@geus.dk

or at

$$
\text { www.geus.dk/publications/bull }
$$

(C) De Nationale Geologiske Undersøgelser for Danmark og Grønland (GEUS), 2011

For the full text of the GEUS copyright clause, please refer to www.geus.dk/publications/bull 


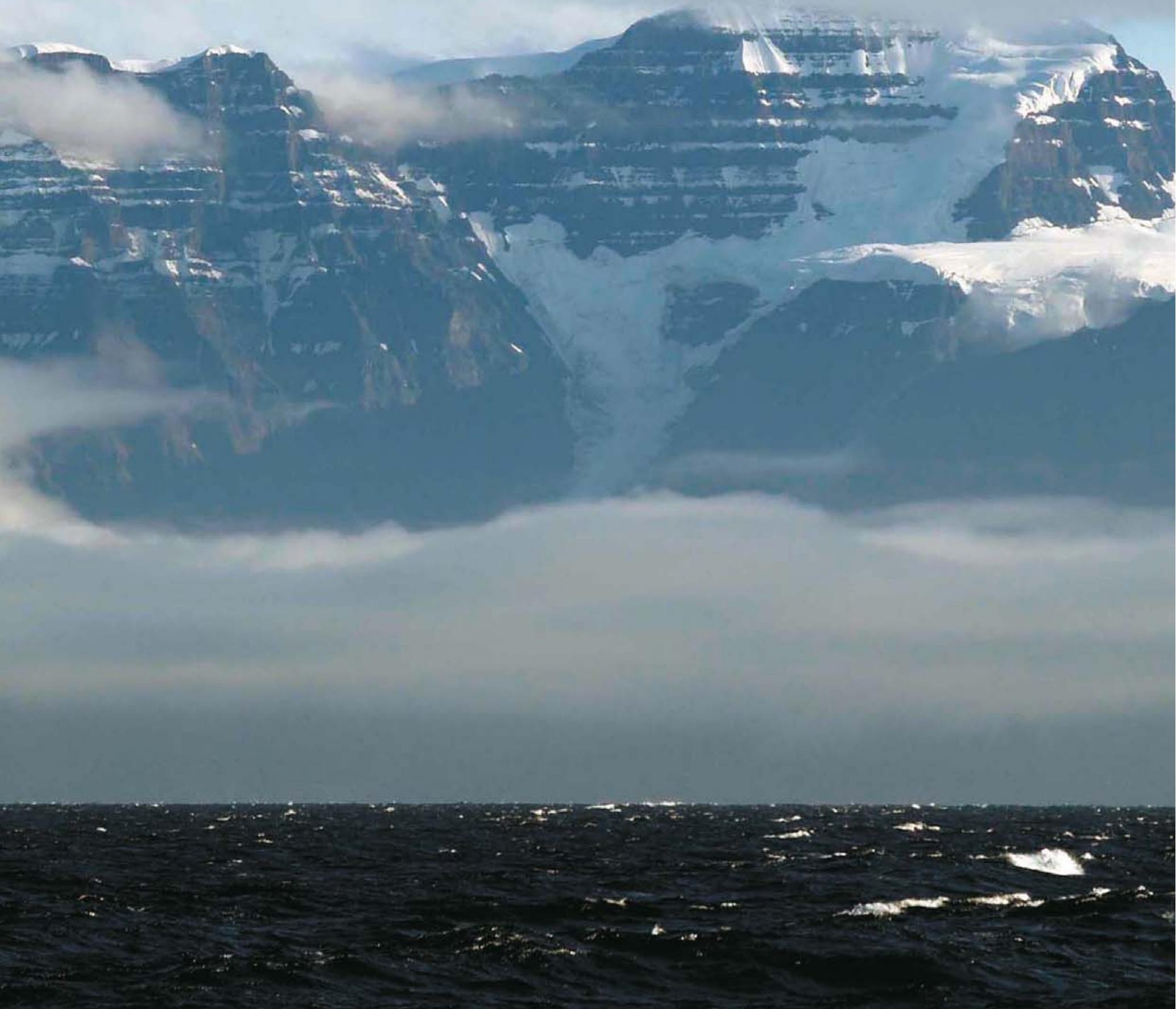




\section{Contents}

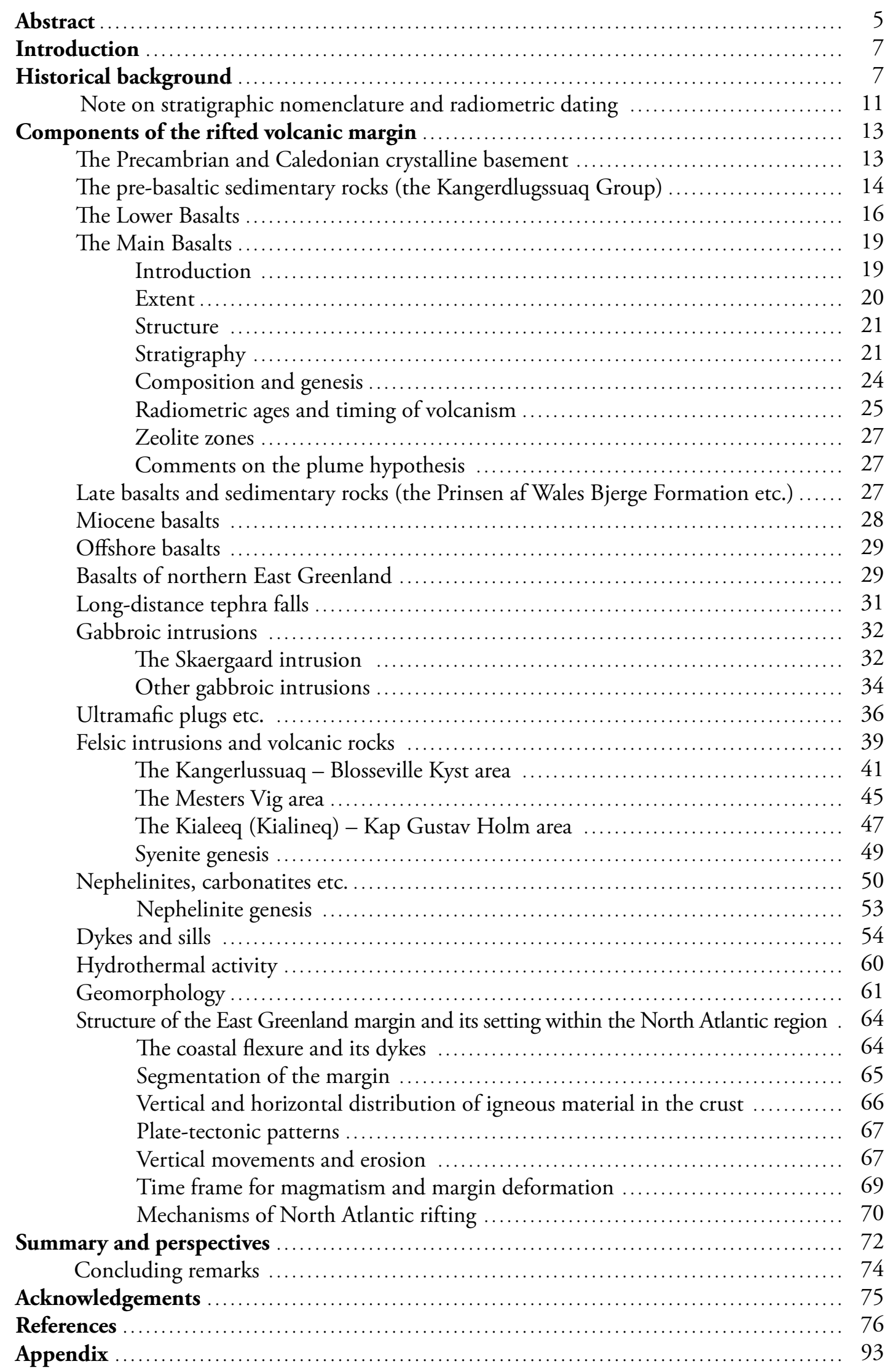




\section{Abstract}

Brooks, C.K. 2011: The East Greenland rifted volcanic margin. Geological Survey of Denmark and Greenland Bulletin 24, 96 pp.

The Palaeogene North Atlantic Igneous Province is among the largest igneous provinces in the world and this review of the East Greenland sector includes large amounts of information amassed since previous reviews around 1990 .

The main area of igneous rocks extends from Kangerlussuaq $\left(c .67^{\circ} \mathrm{N}\right)$ to Scoresby Sund $(c$. $\left.70^{\circ} \mathrm{N}\right)$, where basalts extend over $c .65000 \mathrm{~km}^{2}$, with a second area from Hold with Hope $(c$. $\left.73^{\circ} \mathrm{N}\right)$ to Shannon $\left(c .75^{\circ} \mathrm{N}\right)$. In addition, the Ocean Drilling Project penetrated basalt at five sites off South-East Greenland. Up to $7 \mathrm{~km}$ thickness of basaltic lavas have been stratigraphically and chemically described and their ages determined. A wide spectrum of intrusions are clustered around Kangerlussuaq, Kialeeq $\left(c .66^{\circ} \mathrm{N}\right)$ and Mesters Vig $\left(c .72^{\circ} \mathrm{N}\right)$. Layered gabbros are numerous (e.g. the Skaergaard and Kap Edvard Holm intrusions), as are under- and oversaturated syenites, besides small amounts of nephelinite-derived products, such as the Gardiner complex (c. $69^{\circ} \mathrm{N}$ ) with carbonatites and silicate rocks rich in melilite, perovskite etc. Felsic extrusive rocks are sparse. A single, sanidine-bearing tuff found over an extensive area of the North Atlantic is thought to be sourced from the Gardiner complex.

The province is famous for its coast-parallel dyke swarm, analogous to the sheeted dyke swarm of ophiolites, its associated coastal flexure, and many other dyke swarms, commonly related to central intrusive complexes as in Iceland. The dyke swarms provide time markers, tracers of magmatic evolution and evidence of extensional events. A set of dykes with harzburgite nodules gives unique insight into the Archaean subcontinental lithosphere.

Radiometric dating indicates extrusion of huge volumes of basalt over a short time interval, but the overall life of the province was prolonged, beginning with basaltic magmas at $c .60 \mathrm{Ma}$ and continuing to the quartz porphyry stock at Malmbjerg $\left(c .72^{\circ} \mathrm{N}\right)$ at $c .26 \mathrm{Ma}$. Indeed, activity was renewed in the Miocene with the emplacement of small volumes of basalts of the Vindtoppen Formation to the south of Scoresby Sund.

Although the basalts were extruded close to sea level, this part of East Greenland is a plateau raised to $c .2 \mathrm{~km}$, but the timing of uplift is controversial. Superimposed on the plateau is a major dome at Kangerlussuaq.

East Greenland presents a rich interplay between magmatic and tectonic events reflecting the birth of the North Atlantic Ocean. It was active over a much longer period (36 Ma) than other parts of the province ( $5 \mathrm{Ma}$ in the Hebrides, Northern Ireland and the Faroe Islands) and contains a wider range of products, including carbonatites, and felsic rocks tend to be granitic rather than syenitic. As expected, there are many similarities with Iceland, the present-day expression of activity in the province. Differences are readily explained by higher production rates and the thicker lithospheric lid during the early stages of development in East Greenland. The igneous and related activity clearly results from plate-tectonic factors, but the relationship is not understood in detail. In particular, the nature of the underlying mantle processes, primarily the presence or absence of a plume, is still not resolved.

Author's address

Natural History Museum of Denmark, Øster Voldgade 5-7, DK-1350 Copenhagen K, Denmark.

E-mail:kent2039@live.com 


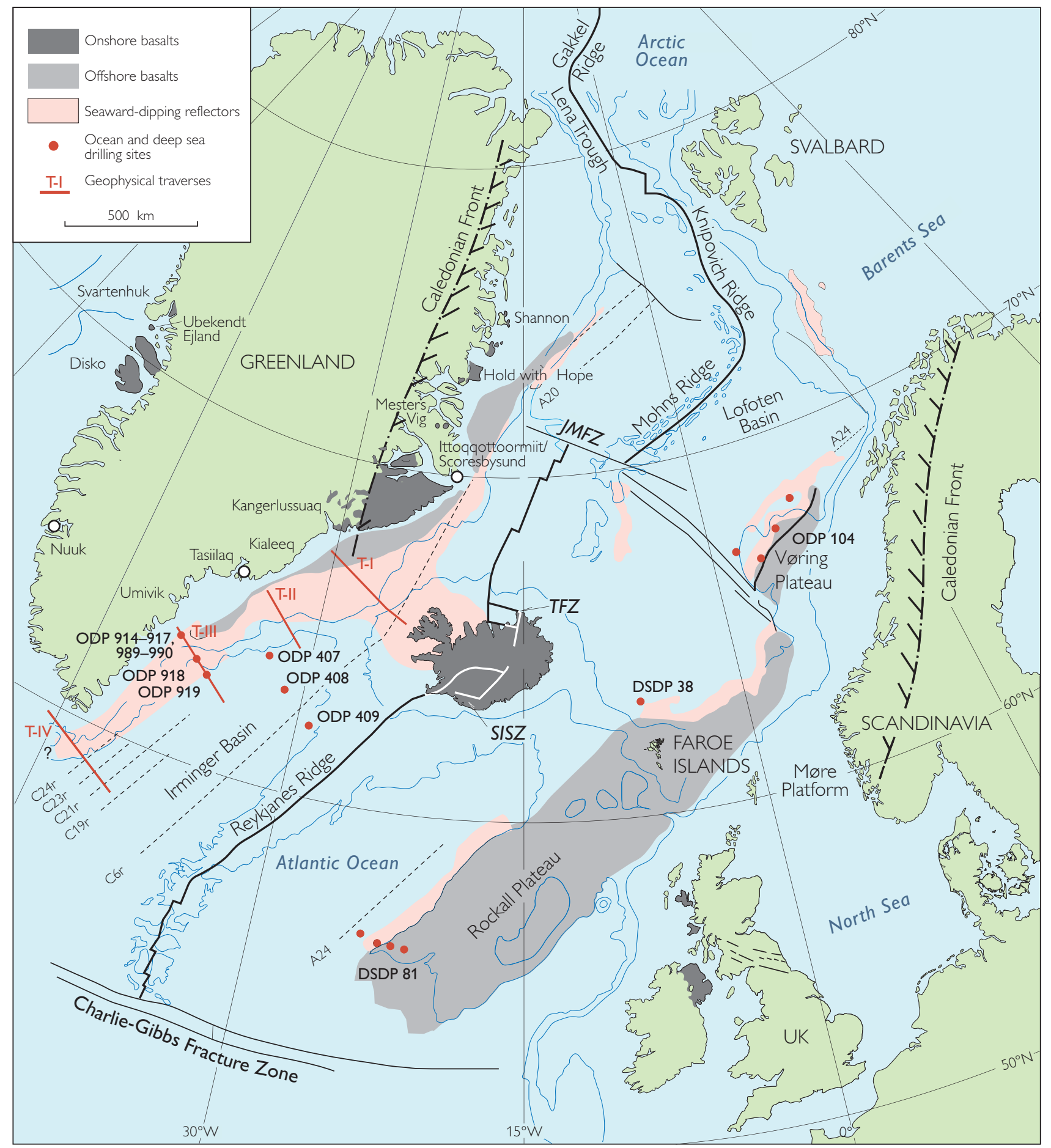

Fig. 1. The North Atlantic Igneous Province, showing onshore and offshore basalts, dipping reflector sequences, the Caledonian front and offshore magnetic anomalies. Sites of the Ocean Drilling Program (with prefix ODP), its precursor the Deep Sea Drilling Project (DSDP) and geophysical traverses of the SIGMA project (T-I to T-IV) are also shown on the East Greenland margin, H.C. \& Duncan 1996; Holbrook et al. 2001). A small area of basalt in Baffin Island (Canada) is not shown. SISZ: South Iceland Seismic Zone. TFZ: Tjörnes Fracture Zone. JMFZ: Jan Mayen Fracture Zone. 


\section{Introduction}

In 1874, J.W. Judd, a leading British geologist, wrote: "In the Hebrides I will now show that we have supplied to us that great geological desideratum - a number of volcanoes so dissected by the scalpel of denudation as to constitute, as it were, a series of anatomical preparations, from which we may learn directly the internal structure of the piles, and obtain bases for reasoning on the causes to which that structure owes its origin." (Judd 1874, p. 232). How much more ecstatic he would have been had he been able to work on the equivalent rocks on the western side of the Atlantic Ocean, in East Greenland, where exposures are orders of magnitude more extensive, more varied and more deeply dissected with vertical topography about three times greater due to subsequent greater uplift. Moreover, outcrops are often scoured clean by recent glaciers, and obscuring vegetation and superficial deposits are frequently lacking. The uplift and consequent vertical exposure make the area ideal for an analysis of the interplay of magmatism and tectonism during continental extension and subsequent lithospheric rupture.

This paper presents an overview of the East Greenland part of the North Atlantic Igneous Province, one of the Earth's largest igneous manifestations (Fig. 1). The justification for this overview is that vast amounts of work have been published since previous reviews by Wager (1934, 1947), Deer (1976), Noe-Nygaard (1976), Brooks \& Nielsen (1982a). In addition, Nielsen (1987)

\section{Historical background}

Previously, East Greenland was effectively out of reach of ordinary geologists due to its remoteness, its lack of any infrastructure and the almost impenetrable sea ice constantly drifting down from the Arctic Ocean. Expeditions had to be major, self-sufficient undertakings which were often isolated for months or even years at a time. For example, L.R.Wager led a year-long expedition here as late as 1935-1936, during which there was no contact with the outside world (Wager 1937). Today dealt specifically with the alkaline rocks, and Upton (1988) and Saunders et al. (1997) covered the entire North Atlantic Igneous Province. This work also points to the now voluminous literature of the East Greenland part. At the present time, abundant research is continuing on the Skaergaard intrusion, although details of this largely fall outside the subject of this paper. The North Atlantic Igneous Province is best known for the extensive literature on its British part. The East Greenland sector is much less known, although it is by far the most voluminous and diverse part of the province and deserves to be better documented.

This review focuses on published work mainly pertaining to the area between Kangerlussuaq and Scoresby Sund (Kangertittivaq) which is clearly the most productive part of the North Atlantic Igneous Province in terms of volumes of magma, with innumerable major intrusions and over $65000 \mathrm{~km}^{2}$ of lavas attaining a maximum thickness of over $7 \mathrm{~km}$. Also included are the areas to the north of Scoresby Sund and to the south as far as Tuttilik, as shown in Fig. 2. It does not consider the offshore geology in detail, except where relevant to the overall picture. Offshore geology can be found in Larsen, H.C. $(1984,1990)$ and the two volumes from the Ocean Drilling Program dealing with the drilling off South-East Greenland (Proceedings of the Ocean Drilling Program, Scientific Results, vols 152 and 163).

the main obstacles for scientists are financial. Access in recent years has been by air, using STOL aircraft on gravel airstrips as well as helicopters, thus eliminating the uncertainty of ship navigation in ice-filled waters. Consequently, many individual geologists and small groups have been fortunate to work in the area (albeit generally under the umbrella of well-organised expeditions), and great strides have been made in the description and understanding of the Palaeogene ge- 
ology. Moreover, mining companies have been active since 1986 (in fact since the 1950s north of Scoresby Sund), greatly expanding the logistical opportunities for scientists.

The earliest studies of Cenozoic igneous rocks in East Greenland were those of Nordenskjöld (1909), Backlund \& Malmquist (1932) and Krokström (1944). These publications dealt with rocks north of Scoresby Sund (see Fig. 2) as there was reportedly an agreement that the land to the south was to be left to British geologists, who were establishing a presence there during the 1930s. These publications are now of historical interest only, but note that Holmes (1918) obtained information for his classical description of basaltic rocks of the Arctic region from Nordenskjöld (1909).

Knowledge of the area has greatly expanded in recent years, largely due to major expeditions in 1994, 1995 and 2000 under the auspices of the Danish Lithosphere Centre (see below). As many as 60 geologists in a season took part in these expeditions, working from remote field camps, usually in two-man groups.

This review is not intended to dig deeply into the petrogenesis of the rocks - most of the references contain speculations as to the origins of the features described. Probably, it is true to say that rarely has a consensus emerged and it is not the intention to overburden the literature with more speculation: conclusions tend to vary with time but observations are hopefully largely fixed. This paper serves as a guide to the currently rather voluminous literature and aims to answer the questions: 'What's there, where is it and when did it happen?' Only to a lesser extent is asked the question 'why?'

Although broadly connected with the genesis of the North Atlantic Ocean (e.g. Brooks 1973), the East Greenland rifted volcanic margin formed over a much more protracted period (c. $26 \mathrm{Ma}$ ) in the Palaeogene and produced magmas spanning an extremely broad spectrum of rock types such as tholeiitic and alkali basalts, nepheline- and quartz-syenites, nephelinites and carbonatites, all contributing to making it an attractive research object. The rocks potentially contain a wealth of information on the interplay of processes of magma genesis, rifting, continental break-up and early ocean-floor formation; information extending in both time and space. Although it was widely accepted for
Facing page:

Fig. 2. Geology of the East Greenland margin showing the crystalline basement (Precambrian and Caledonian), Palaeozoic/ Mesozoic basins, the extent of plateau basalts and the locations of the main intrusive centres. (Of the following geological localities: Aputitêq - Aputiteeq; Igtutarajik - Ittutarajik; Kialineq - Kialeeq; Nûgâlik - Nuugaalik; Pátûlâjivit - Pattuulaajivit, the second name is given in modern spelling. See also Fig. 10).

many years that the North Atlantic Igneous Province is the surface manifestation of a deep mantle plume still active today in Iceland (Morgan 1971; Brooks 1973; White \& McKenzie 1989) and possibly the same which gave rise to the Siberian Traps (Smirnov \& Tarduno 2010), the subject has recently become much more controversial (e.g. DePaolo \& Manga 2003; Foulger \& Natland 2003; Foulger et al. 2005 reviewed by Class 2008; Foulger 2010). It is worth recalling that the general mantle plume hypothesis was so widely accepted at its time of proposal because it elegantly explained many observed and hitherto enigmatic features, e.g. hot spots, the chain of Hawaiian islands, aseismic ridges and many more. More recently, seismologists have claimed to be able to identify the hot roots of both Iceland and Hawaii extending deep into the mantle (Wolfe et al. 1997, 2009; Ritsema et al. 2011). Thus any rejection of the mantle plume hypothesis must provide very convincing alternative explanations. Ultimately, it may emerge that both views have merit, in that several plumes have been shown to have a gabbroic signature (e.g. Sobolev et al. 2000; Stroncik \& Devey 2011), suggesting the presence in the source regions of subducted ocean floor as required by the plume opponents. Whatever the truth, the enormous volumes of igneous rock produced over a very short period count as one of the major geological events in our planet's history, possibly with global implications to the biosphere (e.g. Eldholm $\&$ Thomas 1993). An understanding of the causes and effects of such large igneous provinces is essential to our understanding of the Earth system, and the presence or absence of mantle plumes remains a central question.

The North Atlantic Igneous Province, as it is generally known today ${ }^{1}$, is one of the largest igneous provinces

\footnotetext{
${ }^{1}$ Originally studied by Holmes (1918), who called it the 'Brito-Arctic Province', it has also been called the 'Thulean Province', a name to be discouraged as it has precedence for extensive Proterozoic rocks in northern West Greenland (Wenk 1961).
} 


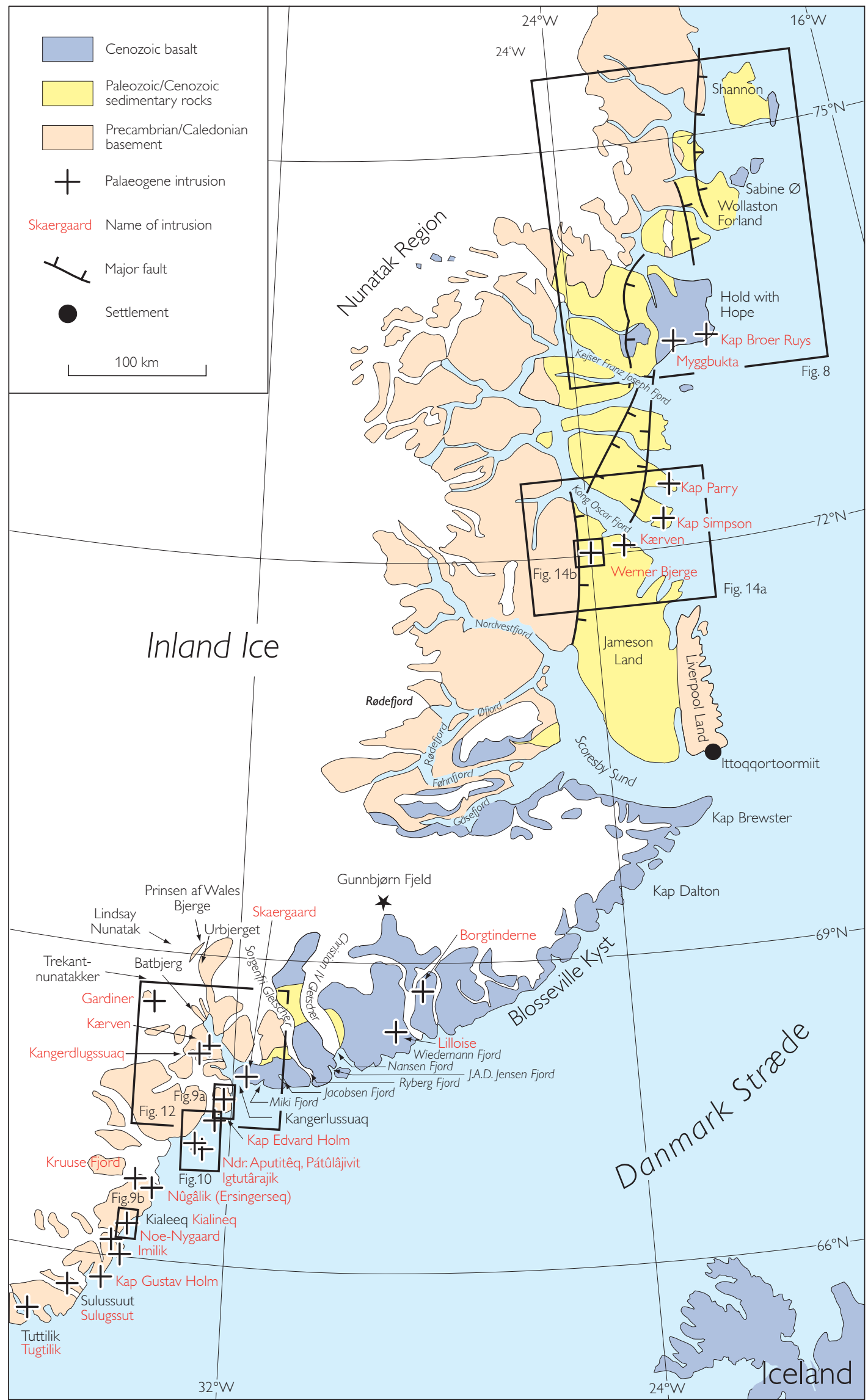


in the world (Fig. 1; for an overview see Upton 1988 and Saunders et al. 1997). It has produced c. $10 \times 10^{6} \mathrm{~km}^{3}$ of magma (Eldholm \& Grue 1994; Holbrook et al. 2001). The Greenland sector contains by far the largest amount of onshore, exposed magmatic material in the form of an extensive lava plateau, intense dyke swarms and numerous plutonic complexes. While the vast bulk of the lavas and dykes are tholeiites, and some of the intrusions have a similar composition, many major felsic intrusions also occur which are both under- and over-saturated with silica, but mainly just saturated (i.e. syenites). In addition, subvolcanic complexes, dykes and extrusives belonging to the nephelinite/carbonatite suite are also found, possibly related to fractures or accommodation zones at a high angle to the continental margin (Karson \& Brooks 1999). Extensive offshore areas of igneous rocks also occur, both as extensions of onshore lava plateaux and as seismic seaward-dipping reflectors (Larsen, H.C. \& Jakobsdóttir 1988), interpreted and subsequently confirmed by drilling as lava flows. The occurrence of these various rock types is clearly related not only to the horizontal movement of continental break-up, but is also intimately connected to vertical movements of the lithosphere, which are responsible for the pronounced present-day topography. Thus the highest mountain within the Arctic Circle, the $c .3700 \mathrm{~m}$ Gunnbjørn Fjeld (Fig. 2), is found here. L.R. Wager, who had previously been close to the summit of Mt. Everest, led the Anglo-Danish first ascent of Gunnbjørn Fjeld and used the opportunity for important geological observations on the plateau basalts and underlying sedimentary beds (see Courtauld 1936).

Uplift is thought to have continued into the Neogene and is subject to an ongoing study (Miss Green Project, Geological Survey of Denmark and Greenland), but its cause is still obscure. Vertical movements, especially uplift, are difficult to quantify both in magnitude and timing, but have been addressed in recent years both by landscape analysis and fission-track dating. As noted above, this uplift of East Greenland gives substantial vertical exposure providing great advantages to geologists. Similarly, the exposure is superb. Essentially, only ice fields and glaciers block exposure and where the rocks are seen they often present clean, glacially polished surfaces. This contrasts to many similar areas around the world that have subsided and become covered with younger sediments or thick regolith.

The conjugate, eastern margin of the North Atlantic Igneous Province (Fig. 1), which includes the Vøring Plateau, Faroe Islands, Rockall and Hatton Bank and the British Hebridean Province ${ }^{2}$, is not uplifted to the same extent as in East Greenland; in fact it is largely submerged except for the Faroe Islands. Consequently, it is not dissected to the same extent and only exposes a relatively limited range of rock types. Furthermore, it was only active for a fraction of the period exhibited in East Greenland. Only the isolation of the East Greenland sector has worked against the very numerous and comprehensive studies seen in the Hebrides, which, with the notorious exception of the Skaergaard intrusion, makes them the most studied igneous rocks in existence.

Previously, most geologists' knowledge of East Greenland would have been limited to the work of Wager \& Deer (1939) and Wager \& Brown (1968) on the Skaergaard intrusion, which rapidly became the best documented igneous body in the world (see Young 2003, pp. 309-326). Lately, also the regional geology has come to the attention of geologists worldwide, largely due to the work of the now defunct Danish Lithosphere Centre (Larsen, H.C. et al. 1995; Brooks et al. 1996; Nielsen et al. 2001). Moreover, in the 1980s and 1990s there was a worldwide surge of interest in large igneous provinces (LIPs) and what such provinces might tell us about the interior workings of the Earth (e.g. the validity of the plume hypothesis and the nature of mantle convection), their role in planetary geochemical cycles and their possible role in global extinctions.

The Skaergaard intrusion became so well known not only due to the work of L.R. Wager and W.A. Deer, but also because of the fortunate juxtaposition of good exposure and uplift, creating a good stratigraphic section, and the fact that the intrusion crystallised as a closed system, i.e. with a single injection of magma and no extrusion of lava. Only a broad outline of its history and research is given here, as any comprehensive description would require its own voluminous memoir. Indeed, about 500 papers have been published on the intrusion, and a collection of abstracts can be found at http://www.skaergaard.org. Although L.R. Wager and

\footnotetext{
${ }^{2}$ Note that the Hebridean Province is far removed from the shelf edge: the true conjugate margins for southern/central East Greenland are the Faroe Islands and the Hatton Bank.
} 
his companions concentrated on the Skaergaard intrusion, they also made remarkably fine maps and descriptions of the geology of the surrounding area (Wager 1934, 1947), which they covered on protracted dogsledge trips (Wager 1937). Wager also provided the first descriptions of the geology from south of Ammassalik (now Tasiilaq) to Scoresbysund (now Ittoqqortoormi$\mathrm{it}^{3}$ ), a distance of over $800 \mathrm{~km}$ (Fig. 2); descriptions and maps which have subsequently been shown to be essentially correct. In the 1970s and early 1980s, this work was extended by small university groups (e.g. Brooks $\&$ Nielsen 1982a). In the 1980s and early 1990s, collaboration with mineral exploration activity focused on mafic intrusions: Skaergaard, Kruuse Fjord and Kap Edvard Holm (Bird et al. 1991, 1995; Arnason et al. 1997a, b; Arnason \& Bird 2000), which in turn provided a boost to the university studies. For an overview of the Skaergaard mineral deposit, see Nielsen et al. (2005). In the period 1994 to 2002, the Danish Lithosphere Centre was active in the area with major, helicopter-supported expeditions in 1994, 1995 and 2000 (Larsen, H.C. et al. 1995; Brooks et al. 1996; Nielsen et al. 2001). During these expeditions the prime targets were a comprehensive, flow-by-flow collection from eight composite sections of the lavas backed up by oblique stereoscopic aerial photography covering more than $1600 \mathrm{~km}$ of the mountain sides, a new collection covering the entire stratigraphy of the Skaergaard intrusion and new collections from several other intrusions including the major Kangerdlugssuaq alkaline complex $\left(c .800 \mathrm{~km}^{2}\right)$. This field work was supplemented by major and minor element analysis, isotopic studies and an extensive ${ }^{40} \mathrm{Ar} /{ }^{39} \mathrm{Ar}$ dating programme, while the aerial photography allowed 3D photogrammetric interpretation of the architecture of the lava pile. The structure of the margin was investigated in an offshore, multi-channel, seismic survey (SIGMA Project, Holbrook et al. 2001) and several sites were successfully drilled by the Ocean Drilling Program (Leg 152: Larsen, H.C. \& Saunders 1998; Leg 163: Larsen, H.C. \& Duncan 1996). This was a major data-gathering period, the results of which are likely still being digested, especially since the demise of the DLC and dispersal of interested researchers.
Likewise, mapping and collecting from the areas north of Scoresby Sund were made from the 1970s onwards under the auspices of the Geological Survey of Greenland (presently the Geological Survey of Denmark and Greenland; see later sections).

\section{Note on stratigraphic nomenclature and radiometric dating}

The stratigraphic nomenclature adopted in the following text and shown in Fig. 3 is largely due to Wager (1947), who divided the sequence into four main units. The Kangerdlugssuaq Group comprising the pre-basaltic sedimentary rocks (the Sorgenfri and Ryberg Formations) was overlain by the Lower Basalts consisting of the Vandfaldsdalen and Mikis Formations (mainly lavas) and the Main Tuffs (predominantly pyroclastics; now called the Hængefjeldet Formation). Above this came the Main Basalts, comprising the bulk of the lavas along Blosseville Kyst and its hinterland, and finally the Prinsen af Wales Lavas succeeding the Main Basalts.

Soper et al. (1976a) used a slightly different nomenclature. They called the entire volcanic succession the Blosseville Group and divided it into the same three formations of the Lower Basalts, plus the Irminger Formation, which corresponds to the Main Basalts of Wager (1947) and this work.

On the basis of very detailed work in the Scoresby Sund area and later to the south, these Main Basalts were subdivided by Larsen, L.M. et al. (1989) into the Magga Dan, Milne Land, Geikie Plateau, Rømer Fjord and Skrænterne Formations (Fig. 3) - note that The Magga Dan Formation, which is of rather localised extent, has subsequently been incorporated into the Milne Land Formation (L.M. Larsen, personal communication 2002). The Nansen Fjord Formation (currently thought to be the uppermost division of the Lower Basalts) was added later as a result of the Danish Lithosphere Centre's work in the Nansen Fjord area (Larsen, L.M. et al. 1999). Some uncertainty about this

\footnotetext{
${ }^{3}$ As far as possible, spelling of place names follow the current orthography for the Greenlandic language. Geological names maintain the older spelling, as they were first reported. A complication arises because some place-name spellings are in the local East Greenlandic dialect, others in the official West Greenlandic. Equivalent Danish names may also occur. In the final instance, the names on the latest editions of the 1:250 000 scale topographic maps (Kort \& Matrikelstyrelsen, Denmark) are used. North of Scoresby Sund, Higgins (2010) has comprehensively covered all place names.
} 


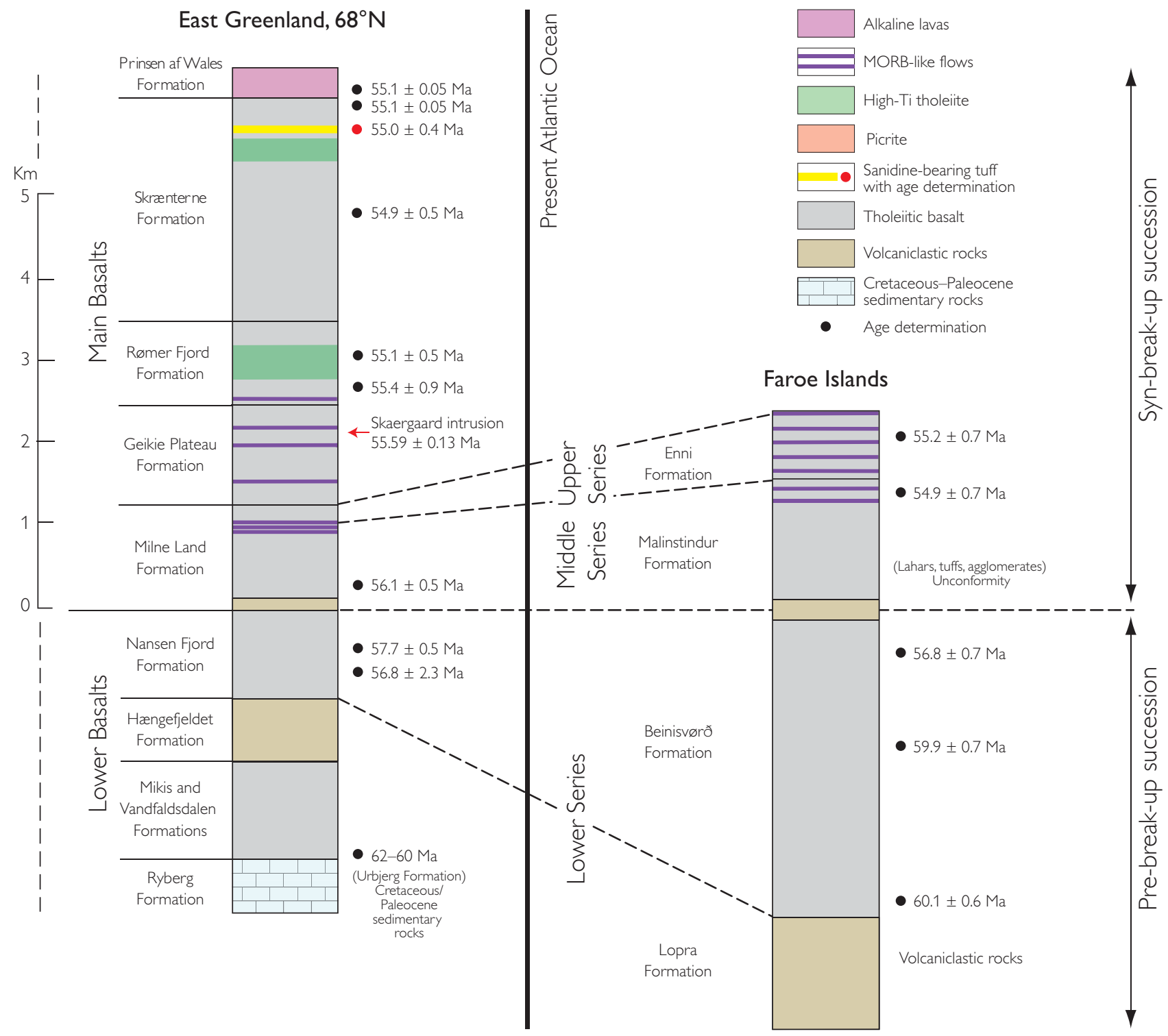

Fig. 3. Correlation of the lava formations in East Greenland and on the Faroe Islands (from Larsen, L.M. et al. 1999), showing stratigraphic divisions and ages from Storey et al. (2007b). Chemical types indicated by different colours, as labelled. Stratigraphy of the Faroe Islands from Passey \& Jolley (2009), but correlation in detail uncertain. Position of the Skaergaard intrusion in this stratigraphy from Larsen, R.B. \& Tegner (2006).

area remains, largely due to the gap caused by the 20 $\mathrm{km}$ wide Christian IV Gletscher (Fig. 2). Overlying the Main Basalts are the Prinsen af Wales lavas inland and the limited remnants of the Igtertivâ Formation on the coast, where the post-basaltic sedimentary rocks of the Kap Dalton and Kap Brewster Formations are found. Later, also the Miocene Vindtoppen Formation of only restricted extent was discovered (Story et al. 2004). The latter four formations are not shown in Fig. 3.
Geology is a historical science, and an accurate knowledge of timing is essential. In the present context, correlations between igneous activity in different places and between this activity and plate-tectonic events require accurate radiometric dates. Most of the older geochronological work on the East Greenland rifted margin was done using the K-Ar method, but this has subsequently proved to be unreliable. The history of dating of the Kræmer $\varnothing$ syenite is taken as an example. Geological investigations show that this is a single in- 
Table 1. K/Ar age data, Kræmer $\varnothing^{\dagger}$

\begin{tabular}{lll}
\hline sample number & mineral dated & result (Ma) \\
\hline Group 1 & & \\
8045 & amphibole & $60.2 \pm 1.9$ \\
8041 & biotite & $64.2 \pm 2.4$ \\
8026 & amphibole & $58.0 \pm 1.0$ \\
8025 & amphibole & $63.1 \pm 1.2$ \\
average (mineral ages) & & 60.4 \\
& isochron age & $49.5 \pm 0.06$ \\
Group 2 & & \\
8032 & amphibole & $54.9 \pm 1.0$ \\
8029 & amphibole & $54.3 \pm 1.0$ \\
8027 & amphibole & $54.4 \pm 1.1$ \\
average (mineral ages) & & 54.5 \\
& isochron age & $49.3 \pm 0.2$ \\
\hline
\end{tabular}

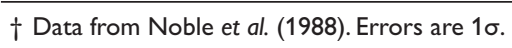

trusion, so a single crystallisation age is expected. Noble et al. (1988) reported the results shown in Table 1, which fell into two groups. It is clear that the authors have gone to great lengths to establish the true age, but we are left in a quandary: Is the age c. $69 \mathrm{Ma}, c .54$ $\mathrm{Ma}$, or $c .49 \mathrm{Ma}$ as shown by the isochrons? (Note: this locality is one of the few where data allow the calculation of isochron ages; in other cases, one has to make do with one or two K-Ar ages which can hardly be assessed). Tegner et al. (2008) obtained a ${ }^{40} \mathrm{Ar} /{ }^{39} \mathrm{Ar}$ date on biotite of $50.4 \pm 0.1 \mathrm{Ma}$, which is close to the two isochron ages and is also most reasonable geologically. The oldest age of Noble et al. (1988) is unacceptable for geological reasons. This example shows that no confidence should be placed on K-Ar ages although they are still frequently quoted in the literature about the East Greenland rifted volcanic margin. A selection of newer and reliable age determinations from different parts of the region is presented in the Appendix. The data come from several different sources and are mainly ${ }^{40} \mathrm{Ar} /{ }^{39} \mathrm{Ar}$ determinations.

\section{Components of the rifted volcanic margin}

\section{The Precambrian and Caledonian crystalline basement}

No detailed study of the Precambrian basement in the Kangerlussuaq area has been published. The area largely consists of quartzo-feldspathic orthogneisses and local paragneisses, in amphibolite, locally granulite, facies typical of such rocks in the North Atlantic craton and other parts of Greenland. These rocks are generally assumed to be the eastward continuation of the Archaean craton on the northern side of the Palaeoproterozoic Nagssugtoqidian fold belt of West Greenland (e.g. Henriksen 2008, p. 30; Nutman et al. 2008). A ${ }^{207} \mathrm{~Pb} /{ }^{206} \mathrm{~Pb}$ isochron on rocks from the Skaergaard area published by Leeman et al. (1976) gave an age of 2980 $\pm 20 \mathrm{Ma}(1 \sigma)$. This age is consistent with $\mathrm{K}-\mathrm{Ar}$ ages by Wager \& Hamilton (1964) and a Rb-Sr whole-rock isochron from Kræmer $\varnothing$ giving a similar age (C.K. Brooks, unpublished data), confirming that the basement in the Kangerlussuaq area is Archaean.

In detail, these rocks are extremely complex as described by Leeman et al. (1976), who distinguished at least three major events assumed to be earlier than their radiometric age. The events include deposition, deformation and metamorphism of interbedded volcanic and sedimentary units on a pre-existing basement that includes disrupted peridotite bodies, intrusion of granitic and trondhjemitic bodies, which in turn were strongly folded, intrusion of mafic as well as potassiumrich granites and pegmatites and finally a metamorphic event closing with pervasive shearing. The metapelites contain sillimanite, biotite, garnet and quartz, and crystallised at c. $650-700^{\circ} \mathrm{C}$ and $3-4$ kbar pressure.

Some observations on the Precambrian basement from the same area were given by Bird et al. (1985). They noted deformed dolerite dykes and a prominent red shear zone which has acted as a major conduit for meteoric water at some unknown time, but prior to the intrusion of the Palaeogene dykes.

For details of the Caledonian terranes of central and northern East Greenland, the reader is referred to the 
memoirs by Higgins \& Kalsbeek (2004) and Higgins et al. (2008), the paper by Higgins et al. (2004), and the semi-popular works by Henriksen (2008) and Brooks (2009). To the south, the western boundary of the Caledonian fold belt (Fig. 2) is located somewhere in the unexposed area between Scoresby Sund and Nansen Fjord according to Wager \& Hamilton (1964). However, a Caledonian intrusive complex was located at Batbjerg beyond the head of Kangerlussuaq by Brooks et al. (1976a, 1981). In many ways this rather enigmatic occurrence resembles the high-potassium intrusions of Assynt in north-west Scotland by containing pseudoleucite as well as unaltered leucite (Brooks et al. 1975; Gittins et al. 1980). The Scottish intrusions likewise occur in the foreland region of the Caledonian fold belt, being absent from the overlying metasedimentary thrust sheets. Perhaps the question of the location of the Caledonian front in this area needs to be re-assessed.

A swarm of strongly alkaline dykes occurring in the western part of Liverpool Land (Kalkdal) were originally suspected of being Cenozoic in age, perhaps due to their freshness. They are rich in mica and have been called monchiquites. A thorough description of the dykes was made in an unpublished masters project (Kofoed 1998), and they were shown to be of lower Triassic age (Ar-Ar data: isochron age $245 \pm 2 \mathrm{Ma}$; plateau age $243 \pm 5.17 \mathrm{Ma})$. They are witness to an extensional event at this time.

Palaeogene igneous rocks north of Scoresby Sund largely intrude or overlie rift basins in the Caledonian region. These basins are well described (e.g. Surlyk 1990) and are filled with Palaeozoic and Mesozoic sediments, beginning with Devonian deposits. To the west, basalts overlie an uneven crystalline surface of Precambrian and Caledonian age, as can be clearly seen in the inner parts of Scoresby Sund (e.g. Føhnfjord and Gåsefjord). Magmas were thus exposed to contamination from quite different materials. It is clear that after the Caledonian compression events, most of East Greenland underwent protracted, but limited and probably intermittent, extension. In the Kangerlussuaq area, basin formation apparently did not take place until the latest Mesozoic to earliest Cenozoic (although the oldest part of the succession is not exposed). The situation changed dramatically in the Palaeogene when continental rupture occurred with the production of voluminous magmas and subsequent sea-floor spreading during $\mathrm{C} 24 \mathrm{r}$ time which began at c. $57 \mathrm{Ma}$ and lasted $3 \mathrm{Ma}$ (Westerhold et al. 2007). Thus there was a repetition of the opening and spreading of the Iape- tus Ocean (the precursor to the present-day Atlantic Ocean), which had formed the Caledonian mobile belt $500 \mathrm{Ma}$ earlier, and this is a classical example of the Wilson cycle (Wilson 1966).

\section{The pre-basaltic sedimentary rocks (the Kangerdlugssuaq Group)}

Both the pre- and post-basaltic sedimentary rocks are extremely important as they give a clear insight into the environmental conditions before and after the volcanic event, not least the vertical movements that would be expected to be associated with a mantle plume. The picture is complicated. The latest pre-basaltic sedimentary rocks do record an uplift, but this was short-lived and limited, as thick hyaloclastites are found in the base of the basaltic succession.

The following account is largely confined to the basin located in the southern part of the province (Fig. 2), just to the east of Kangerlussuaq (Miki Fjord to Nansen Fjord), a basin which has been little studied until recently. Three outliers are also included: at Kap Gustav Holm, at Kap Brewster and the Palaeogene sedimentary rocks underlying the basalts to the north (i.e. Hold with Hope, Wollaston Forland and Sabine Ø). The northern basalts lie on thick Palaeozoic-Mesozoic basins whose nature is well described elsewhere (e.g. Surlyk 1990; Stemmerik et al. 1993), and it is only the Palaeogene sedimentary rocks that are briefly mentioned here. The post-basaltic sedimentary rocks at Kap Brewster and Kap Dalton are treated in a subsequent section on p. 28.

Studies of the sedimentary rocks (known as the Kangerdlugssuaq Group) and overlying volcanic sequence have been published by Wager $(1934,1947)$, Soper et al. (1976a, b), Higgins \& Soper (1981), Nielsen et al. (1981) and Larsen, M. et al. (1996, 1999a, 1999b, 2001). Traditionally, the sedimentary deposits under the volcanic rocks were divided into the Sorgenfri Formation, now known to be Aptian to Coniacian in age and first identified on the eastern side of the Sorgenfri Gletscher, and the Ryberg Formation, which is Campanian to Danian (Fig. 4). The base of the succession is not exposed, so the oldest sedimentary rocks will be Aptian or older. The earliest sedimentary deposits of the Sorgenfri Formation are estuarine sandstones. The basin then gradually deepened and became increasingly marine, first with marine sandstones, later abundant mudstones. Deep-water conditions lasted 


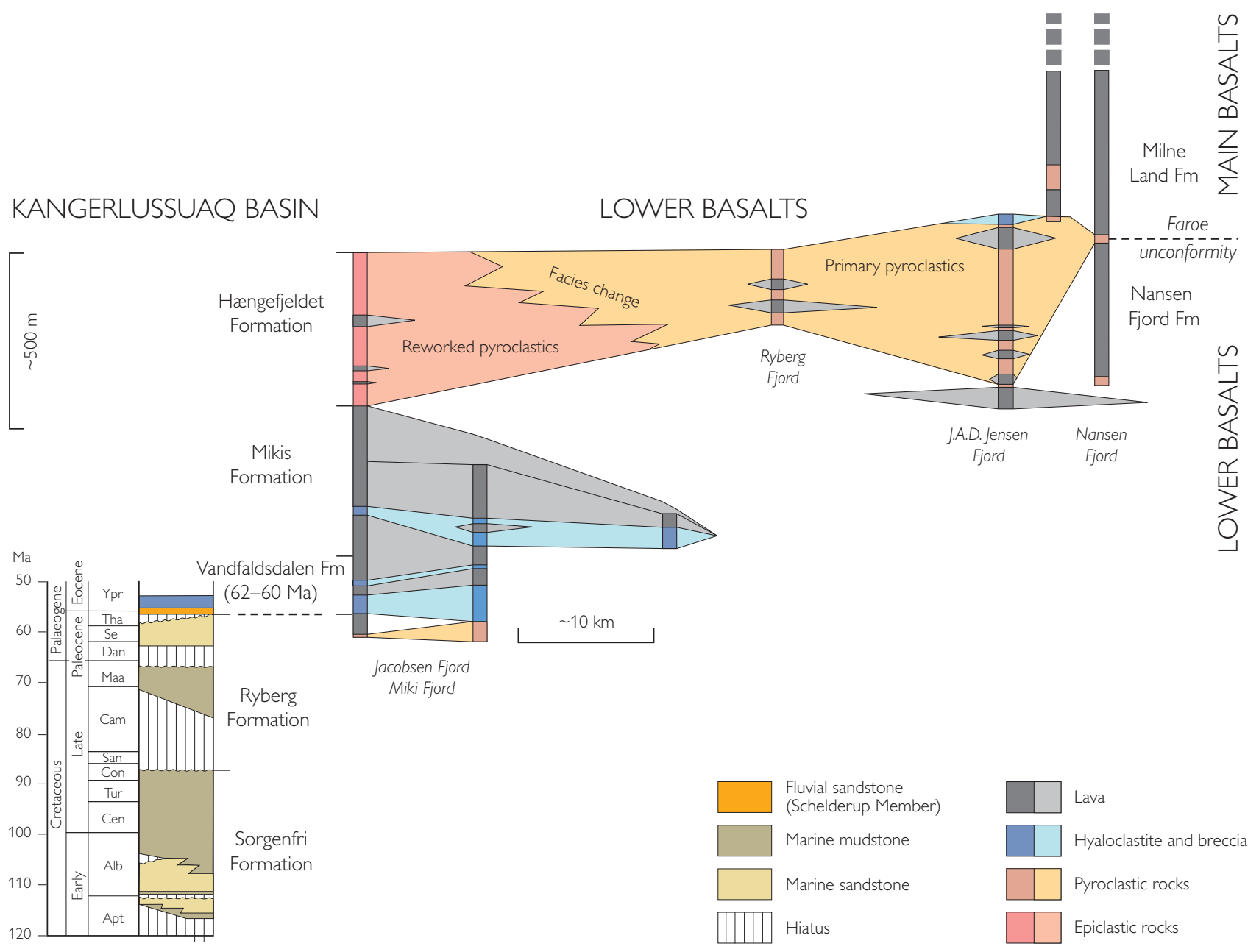

Fig. 4. The pre-basaltic sedimentary succession, redrawn from Larsen, M. et al. (2006), and the Lower Basalts, redrawn from Peate, I.U. et al. (2003), showing the large proportions of fragmental material and the facies changes across the basin. Correlation across the Lower Basalts is hampered by the lack of clear stratigraphic markers and the marked changes in facies. The age of the Vandfaldsdalen Formation relies on a correlation to lavas inland dated by the ${ }^{40} \mathrm{Ar} /{ }^{39} \mathrm{Ar}$ method (Hansen et al. 2002). Note the conflict with the age of the oldest basalts (as determined by radiometric dating and known basalt stratigraphy, see main text), implying that the transition from the Ryberg Formation to the Vandfaldsdalen Formation should be revised to the period 62-60 Ma (see main text).

until the Paleocene (Danian) when uplift occurred, and marine sandstones reappeared in the upper Ryberg Formation. In the mid-Paleocene, an extensive, up to $10-20 \mathrm{~m}$ thick quartz conglomerate sheet, the 'Schjelderup Member' (Fig. 5a), was laid down in an extensive, braided river system over the entire area and is assigned to the overlying Vandfaldsdalen Formation. This was closely followed by basaltic volcanism. Subsidence must then have been renewed, as thick, foresetbedded hyaloclastites indicate a water depth of $>100 \mathrm{~m}$. Similarly, coarse polymict breccia units probably derive from submarine slides. The basin sediments attain a thickness of $c .1 \mathrm{~km}$. The base of the sequence is not exposed in coastal regions where it is thickest, but elsewhere rests on Archaean gneisses; the unconformity is thus diachronous.

The top of the Kangerdlugssuaq Group is set at the base of the fluvial conglomerate known as the Schelderup Member. This is part of a return to siliciclastic sedimentation caused by uplift in the early Paleocene and closely followed by the earliest volcanic deposits. These vertical movements were discussed by 
Clift et al. (1998) - but see the reservations of Dam et al. (1999) - as manifestations of the arriving head of the supposed mantle plume.

Most of the exposed sedimentary rocks belong to the Ryberg Formation. Rich fossiliferous horizons are reported (Soper et al. 1976a; Larsen, M. et al. 2006), including belemnites, shark's teeth (Hoch 1992), ammonites and plants (Ginkgo and Metasequoia have been identified). Earlier workers were hampered by only having access to a few coastal localities, although L.R. Wager examined inland localities during his mountaineering excursion. Increased field coverage has recently revealed a much more complete sedimentary succession, albeit with several significant hiatuses. Several more recent articles (Larsen, M. et al. 1996, 1999a, b) are both extensive and up to date and essentially replace previous work. In a further study, Larsen, M. \& Whitham (2005) suggested that the Kangerlussuaq area was the source of thick sands, which are present in the Faroe-Shetland Basin. This is a significant conclusion regarding petroleum prospectivity. While the onshore Greenland rocks are overmature, traces of hydrocarbons suggest that other offshore basins with sub-basaltic sedimentary rocks are promising (Jonk et al. 2005). A subsequent provenance study (Larsen, M. et al. 2006) using whole-rock chemistry and dating of detrital zircons concluded that the Kangerlussuaq and West Shetland basins were fed from different sources. The pre-basaltic sedimentary rocks and those interbedded with the lowermost of the Lower Basalts were used by Larsen, L.M. et al. (1999a) and Vosgerau et al. (2010) as field analogues for other offshore basins around the North Atlantic Ocean, i.e. the Vøring, Møre, Rockall etc.

A problem remains regarding the timing of the transition from the pre-basaltic sedimentary succession (Ryberg Formation) to the oldest basalts (Vandfaldsdalen Formation). Larsen, M. et al. (2006, fig. 2) showed this as lowest Eocene, but this is the same age as the top of the Main Basalts as determined by radiometric dating and basalt stratigraphy (c. $55 \mathrm{Ma}$, see below). This implies that the transition from the Ryberg Formation to the Vandfaldsdalen Formation should be revised to the period 62-60 Ma.

At Kap Gustav Holm, Wager (1934) reported c. 150 $\mathrm{m}$ of arkosic sandstones overlain by pillow lavas, hyaloclastite tuffs and epiclastic mafic tuffs (see also Myers et al. 1993). The rocks are strongly hornfelsed, and fossil evidence only allowed Wager to conclude that they were not older than Cretaceous. Myers et al. (1993, p.
260) reported that "Late Cretaceous and early Tertiary lamellibranchs occur near the top of the sequence".

A tiny exposure of pre-basaltic sedimentary rocks occurs to the north at Kap Brewster. Nøhr-Hansen \& Piasecki (2002), the latest researchers to examine this exposure, concluded on the basis of dinoflagellate cysts that the lower part of the succession is late Danian while the uppermost part is early Selandian in age, corresponding to $c$. $58 \mathrm{Ma}$. As the immediately overlying basalts belong to the Milne Land Formation of the Main Basalts, there is a hiatus of several million years, although no angular unconformity is seen on seismic profiles (Larsen, H.C. \& Marcussen 1992). The Lower Basalts (Hansen et al. 2002) or their equivalents recorded in offshore boreholes (Sinton \& Duncan 1998) have not been found in the Scoresby Sund area.

On Hold with Hope, Wollaston Forland and Sabine $\varnothing$, small exposures of Palaeogene sedimentary rocks have been described by Nøhr-Hansen et al. (2011). One of the interesting observations reported by these authors is that the exposures in Haredal on Wollaston Forland may contain the Paleocene-Eocene Thermal Maximum which is well dated at $c .55 .8 \mathrm{Ma}$ (Charles $e t$ al. 2011), thus constraining all the overlying basalts to be younger than this. In fact, the topmost sedimentary rocks at this locality are biostratigraphically dated to "not younger than mid-Ypresian" (Nøhr-Hansen et al. 2011, p. 63) which is compatible with the age of the oldest basalt $\left({ }^{40} \mathrm{Ar} /{ }^{39} \mathrm{Ar}\right.$ age $55.02 \pm 0.49 \mathrm{Ma}$ quoted by these authors from L.M. Larsen's personal communication 2008). The underlying sedimentary rocks are of Early to Middle Campanian age, and the Palaeogene sedimentary rocks show a hiatus that probably spans most of the Selandian and Thanetian. The presence of coarse sands and conglomerates free from basaltic clasts and abundant reworked Cretaceous palynomorphs testify to an uplift immediately prior to basalt extrusion.

\section{The Lower Basalts}

As noted above, the entire basaltic sequence (i.e. Lower and Main Basalts, Fig. 3) has been called the Blosseville Group by Soper et al. (1976a, b). The Lower Basalts (informal name) were first recognised by Wager (1934, 1947) in the southern part of Blosseville Kyst from Kangerlussuaq to Nansen Fjord. In this work, the Lower Basalts are taken to include both the Lower Basalts and the Main Tuffs of Wager (1947) or the Vandfalds- 
dalen, Mikis, Jacobsen and Hængefjeldet Formations of Soper et al. (1976a). The more recently introduced Nansen Fjord Formation (Larsen, L.M. et al. 1999) is also tentatively included as it has not yet had its affinities adequately documented, and the correlation across Nansen Fjord is still unclear. The Main Basalts as defined in this work (see below) are the Irminger Formation of Soper et al. 1976a). It is clear that a formalised stratigraphy such as that established by Larsen, L.M. et al. (1989) for the Main Basalts is also needed for the Lower Basalts, although rapid facies changes and lack of marker horizons complicate the picture.

The Lower Basalts have been described by Soper $e t$ al. (1976a, b) and Nielsen et al. (1981), their chemical and isotopic relationships by Holm (1988), Fram \& Lesher (1997) and Hansen \& Nielsen (1999), and their eruptive style by Peate, I.U. et al. (2003). They have a maximum thickness of $c .2 \mathrm{~km}$, with marked facies changes over their exposed area (Fig. 4), which is not seen in the Main Basalts. Furthermore, they contain some prominent picrite flows, which are rare in the Main Basalts.

On the basis of very few samples, the Lower Basalts were first shown by Brooks et al. (1976b) to differ from the overlying Main Basalts in both mode of occurrence and composition, and this has subsequently been confirmed. The lava flows are generally thin, compound pahoehoe flows (Fig. 5b), often with well-preserved pahoehoe structures (Fig. 5c), and hyaloclastites (Fig. $5 \mathrm{~d})$. Compound flows in the sense of Walker (1972) are much more common than in the succeeding Main Basalts. See also Passey \& Jolley (2009) for a description of these lava types in the Faroe Islands. Breccias (probable debris flows), pyroclastic and epiclastic deposits and subaerial scoria cones are common. Much of the observed explosive activity seems to be hydromagmatic in origin. In contrast, fragmental and near-vent facies are relatively rare in the overlying Main Basalts. In general, the Lower Basalts differ from the overlying Main Basalts in being much less voluminous or extensive, and in containing large amounts of pyroclastic and epiclastic material (35-50\%). Isotopic studies (Holm 1988; Hansen \& Nielsen 1999) also show that they are more contaminated with continental material. Perhaps the later, more voluminous magmas overwhelmed the aqueous reservoirs and erupted through channelways armoured by the earlier passage of magmas, reducing their explosivity and contamination. The Lower Basalts also contain some prominent picrite flows and sills, especially in the lower part of the Vandfaldsdalen For- mation. A photomicrograph of a picritic sill emplaced into Lower Basalts is shown in Fig. 5e. Furthermore, there are some interbedded sandstones in the lowermost parts of the Lower Basalts, one of which has been documented in detail by Vosgerau et al. (2010).

It has proved very difficult to obtain a reliable radiometric date for the Lower Basalts due to alteration by burial (prehnite-pumpellyite and greenschist facies: Bird et al. 1986), but they are thought to be contemporaneous with the lowermost lavas drilled offshore SouthEast Greenland (Tegner \& Duncan 1999), with some onshore dykes to the far south (Storey et al. 2007b) and with the lowermost lavas in the inland Urbjerg area, which fall in the range 62-60 Ma (formalised as the Urbjerget Formation: Hansen et al. 2002). This would make them penecontemporaneous with the Vaigat Formation lavas of West Greenland (Storey et al. 1998) and with the lavas of the Small Isles of the Hebrides (Pearson et al. 1996) and place them in magnetochron C26r, well predating any identifiable ocean-floor spreading in the area. There appears to have been a hiatus of several million years between the eruption of these lavas and the overlying Main Basalts, although the transition is not well documented. A similar hiatus occurs in West Greenland, offshore East Greenland and the Faroe Islands, which allows a correlation of these localities (see Fig. 3). In the Hebrides, all volcanism appears to be earlier than $58 \mathrm{Ma}$ (Saunders et al. 1997 and references therein; Chambers et al. 2005) or $55 \mathrm{Ma}$ in the Faroe Islands. However, intrusive activity continued longer (e.g. to $51.5 \pm 1.8 \mathrm{Ma}$ in the case of the granitic Mourne Mountains of Ireland: Meighan et al. 1988). Extrusive activity also continued longer in West and East Greenland, as described below.

Compositionally, the Lower Basalts are variable, with both primitive picrites (Fig. 5e) studied from the point of view of melt inclusions in olivine by Nielsen et al. (2006) and others which have become contaminated with continental crust (Holm 1988; Hansen \& Nielsen 1999), perhaps by the mechanism studied by Blichert-Toft et al. (1992), although their study was based on the later macrodyke. The most recent chemical and isotopic studies by Hansen \& Nielsen (1999) identified Iceland-like lavas contaminated with crustal material: amphibolite facies gneiss in the lower part and granulite facies gneiss in the upper part. The lavas are similar to those drilled offshore to the south on ODP Leg 152, where dacites occur (absent onshore). Also, contamination is more dramatic and its sequence was the reverse (granulite facies contaminants initially, fol- 

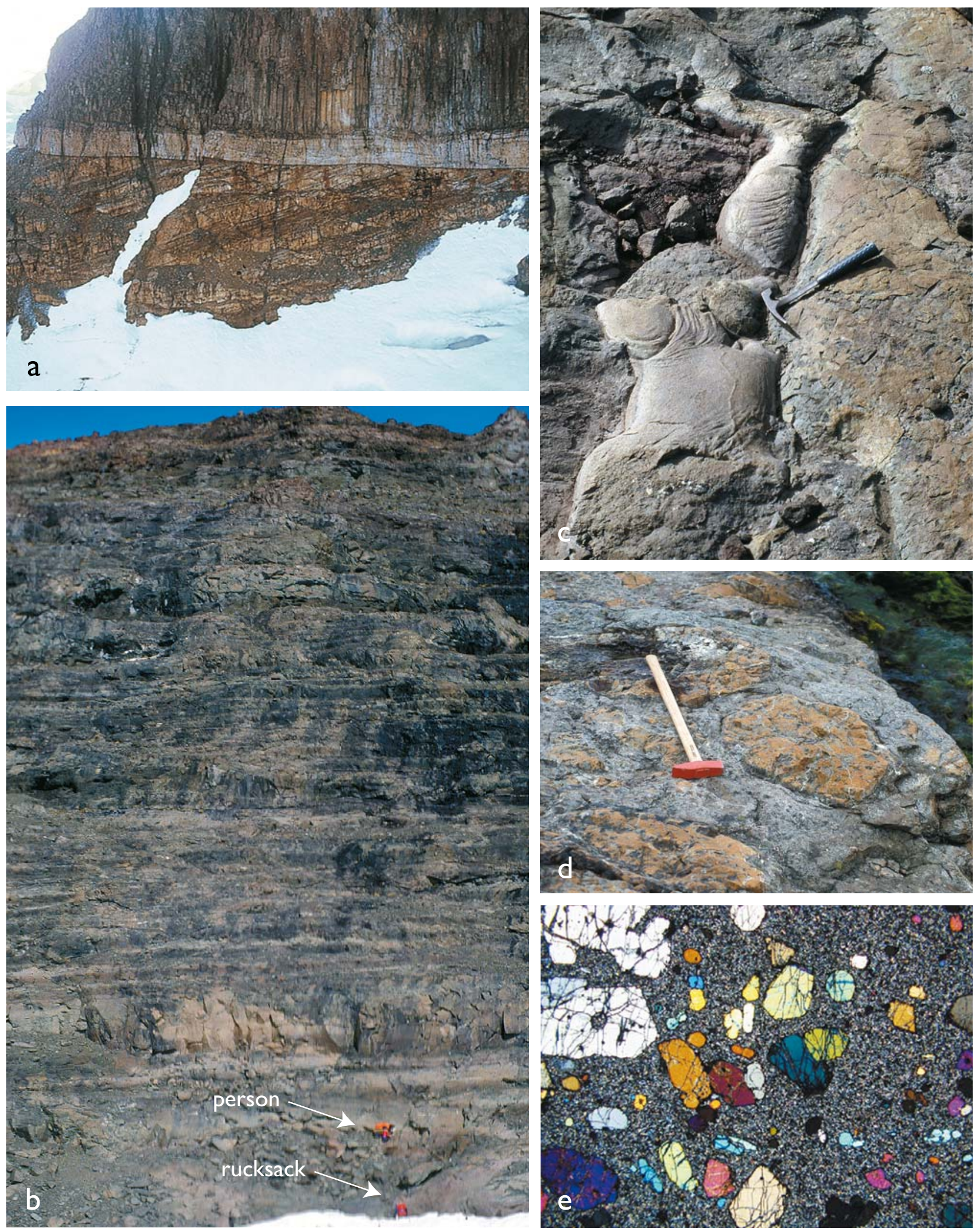
lowed upwards by amphibolite-facies contaminants). It is worthwhile to bear in mind that such contamination studies (including those referred to later) are hampered by the extreme heterogeneity of the likely contaminants (mainly Precambrian rocks), a point stressed by Jensen (1998). The compositional variation in the local gneisses has never been systematically studied, and authors seeking contaminants for basaltic magmas have used available, scattered data acquired for other purposes.

It is thought (Peate, I.U. et al. 2003) that the lower Vandfaldsdalen and Mikis Formations formed shield volcanoes in the Miki Fjord area. These subsequently subsided and created space for epiclastic deposits eroding from new vent areas to the east in the J.A.D. Jensen Fjord area and also, although to a lesser extent, the Nansen Fjord area (Figs 2, 4) where the deposits are largely pyroclastic. These two facies make up the Hængefjeldet Formation of previous authors.

The formation of voluminous hyaloclastic, pyroclastic and epiclastic deposits (which include pillow lavas, breccias, pyroclastic surge deposits, bomb beds and tuffs) is due to three factors: (1) the presence of underlying water-saturated, high-porosity sediment (particularly coarse sands and conglomerates, as seen in both the Sorgenfri and Ryberg Formations), (2) submarine activity and (3) the proximity to vents. For the lower two formations, these vents are thought to have been located to the north of Miki Fjord, and for the uppermost Hængefjeldet Formation in the J.A.D. Jensen Fjord area, where an extensive vent area has been de-

\section{Facing page}

Fig. 5. Lower Basalts and their base. a: Sandstones of the Ryberg Formation overlain by a conglomeratic sheet (the 'Schjelderup Member'), $1 \mathrm{~m}$ thick, which is identified as the 'break-up unconformity' by Larsen, H.C. \& Saunders (1998, fig. 14). Above this is the first columnar basalt flow. The unconformity at the top of the Ryberg Formation is quite small, but appears exaggerated due to the cross-bedding in the underlying sandstones. b: Typical thin, vesicular compound flows in the Mikis Formation (person and rucksack for scale). c: Exhumed pahoehoe toes in the Vandfaldsdalen Formation. d: Hyaloclastite breccia with pillows in Sødalen, from a $300 \mathrm{~m}$ thick unit with foreset bedding. Chilled margins and radial structure of the pillows are clearly seen. e: Photomicrograph of a picrite from sill in the Lower Basalts $(c .0 .5 \mathrm{~cm}$ across, crossed polarizers). Such rocks also occur in the Main Basalts, but rarely as fresh as this sample. scribed. Thus according to Peate, I.U. et al. (2003) the activity seems to have moved with time from the west at Miki Fjord to the east at Nansen Fjord (Fig. 4).

The transition to the overlying Main Basalts is poorly documented. It is largely concealed by the $c .20$ $\mathrm{km}$ wide Christian IV Gletscher, a main outlet from the Inland Ice. It is in this area that the Nansen Fjord Formation occurs, separated from the overlying Milne Land Formation by a breccia horizon. An orthopyroxene-bearing suite promises to be a useful marker horizon (Nielsen et al. 2001). Similar lavas are found in the Faroe Islands (Hald \& Waagstein 1983).

\section{The Main Basalts}

\section{Introduction}

This section deals with outcrops of basalts in the area between Kangerlussuaq and Scoresby Sund $\left(67-70^{\circ} \mathrm{N}\right)$. It covers the extent and structure of the lava pile and its stratigraphy, composition, genesis and timing of eruption. The basalts farther to the north in the Hold with Hope - Shannon area are discussed in a separate section.

There has been an immense augmentation of data on all the basalts since the Oxford expedition (Fawcett et al. 1973) began a second phase of work on them over 40 years ago, when they were only known from the pioneering work of L.R. Wager in the 1930s. The basalt plateau has now been mapped, sampled systematically and in detail, analysed for a wide range of elements and isotopes and dated both biostratigraphically and radiometrically. Previously, such basalt plateaux were seen as boring and uniform. With the benefit of an armoury of geochemical techniques and improved understanding of deep-Earth systems, they are now seen as incomparable windows to the inner workings of the planet.

The Main Basalts (so named by Wager 1947, but as the Irminger Formation by Soper et al. 1976a) are greater than $6 \mathrm{~km}$ in thickness, probably more than 7 $\mathrm{km}$ in places, and are exposed over a vertical distance of almost $4 \mathrm{~km}$ from sea level to the top of Gunnbjørn Fjeld (Fig. 2). Magnificent trap topography abounds, e.g. on the southern side of Scoresby Sund and inland nunataks (see frontispiece and Fig. 6a) and is particularly enhanced when snow lies on the weathered inter- 
flow horizons. Along the southern Blosseville Kyst, trap topography is less evident or absent due to dyke intrusion and incipient metamorphism in this deeper part of the succession which causes flows and dykes to weather as one unit (Fig. 6b).

These lavas are the most extensive in the North Atlantic area and dominate the $400 \mathrm{~km}$ coastline of Blosseville Kyst, imparting its forbidding black aspect, where a succession of high, vertical headlands rise from the inhospitable waters of Danmark Stræde (Fig. 2). As a result of its reputation for impenetrable drift ice, strong currents, thick fogs and high cliffs, this has become Greenland's most feared coastline. The Danish Lithosphere Centre, whose aim was primarily to investigate the basalt plateau, operated using helicopters in 1994, 1995 and 2000 measuring and collecting on a flow-by-flow basis from a comprehensive series of profiles through the entire lava plateau, backed up with airborne stereoscopic imagery (Larsen, H.C. et al. 1995; Brooks et al. 1996; Nielsen et al. 2001). The Cambridge Arctic Shelf Project (CASP) has also operated in the area using snowmobiles. Their aim was probably petroleum-related, but no publications are forthcoming. In recent years, the Miss Green Project (Geological Survey of Denmark and Greenland) has focussed on the evolution of the topography.

The Main Basalts are regarded as contemporaneous with continental break-up. They have an age which corresponds to the earliest offshore magnetic anomalies, they are all reversely magnetised (so far as is known), they contain some compositions typical of oceanic spreading zones, and the great increase in magma productivity is consistent with such a major event. This means that the Lower Basalts are pre-break-up. Magmatic activity at this time extended from eastern Canada to the Hebrides, but according to the widely acclaimed views of Lawver \& Müller (1994), the plume was located under the middle of the Greenland ice sheet. Similarly, when the Main Basalts erupted, the supposed plume was still under the ice sheet, and it was not until at 40-30 Ma that it crossed the coastline east of Kangerlussuaq. These events are not immediately reconcilable with the classic plume model with its broad mushroom-like head and narrow tail as expounded by e.g. Campbell \& Griffiths (1990), and special conditions must be invoked. Moreover, other views on the likely position of the plume head exist. Brooks (1973) placed it under Kangerlussuaq at the time of basalt extrusion, for the simple reason that this was where the magmatic activity was highest, presum- ably the same reason for White \& McKenzie (1989) to place it in the same location. In addition, a completely different plume track was proposed by Forsyth et al. (1986), based on outcrops of volcanic rocks. It must be concluded that the location of the centre of the supposed plume $60-50 \mathrm{Ma}$ ago is in doubt, although its present position is widely agreed to be under Vatnajökull in Iceland.

\section{Extent}

The basalt plateau is described by Wager $(1934,1947)$, Fawcett et al. (1973), Brooks et al. (1976b) and Larsen, L.M. et al. (1989) - the last is by far the most thorough description - and extends from Scoresby Sund to Kangerlussuaq, covering c. $65000 \mathrm{~km}^{2}$. It attains more than $6 \mathrm{~km}$ in thickness, perhaps more than $7 \mathrm{~km}$ locally (Brooks \& Nielsen 1982a; Pedersen et al. 1997), although it is thinner in the Scoresby Sund region $(c$. $3 \mathrm{~km}$ ) and thins inland. However, its original extent was much greater as shown by minor basalt outcrops as far south as the Kialeeq area (formerly Kialineq in the geological literature) and Kap Gustav Holm c. $200 \mathrm{~km}$ south of Kangerlussuaq. Fission track studies show that its thickness south of Kangerlussuaq cannot have exceeded $3 \mathrm{~km}$ (Hansen 2000). Its original extent to the north is unknown, although a substantial basalt plateau exists in the Hold with Hope and Wollaston Forland areas (Fig. 2 and discussed below). Whether these dispersed areas were once united is unknown. Sills and dykes in the intervening area suggest that surface flows may originally have been present here, too (e.g. Larsen, H.C. \& Marcussen 1992; Hald \& Tegner 2000). There is no doubt that igneous activity was present over the entire area, covering more than ten degrees of latitude. It extends offshore forming the shelf in some areas, and in others seaward-dipping reflectors occur directly offshore as a continuation of the coastal flexure (Fig. 1). They eventually pass into Iceland-type oceanic crust (Larsen, H.C. \& Saunders 1998).

It is considered unlikely that the basalts pass under the Inland Ice and connect with those around Disko Bugt in West Greenland, as the basalts are everywhere seen to thin inland, as indeed do those on the west coast. Nevertheless, according to Dawes (2009) there is still a probability that basalts underlie the Inland Ice, though the rationale for this is unclear. 


\section{Structure}

The general impression of the basalt area is one of approximately flat-lying flows forming the classic trap topography (see frontispiece and Fig. 6a). Many of these flows are of immense size: up to hundreds of cubic kilometres in volume (Larsen, L.M. et al. 1989; Pedersen et al. 1997). In detail, however, the plateau has been deformed as described by Pedersen et al. (1997), who used multi-model photogrammetrical analysis using the images obtained in 1995. These authors identified the following features, in part confirming previous reports:

(1) An inland plateau with lava dips of $<2^{\circ}$ (Fig. 6a).

(2) A coastal flexure zone, associated with an intense dyke swarm, with dips of $30-60^{\circ}$ towards the ocean (as originally described by Wager \& Deer (1938), and seen in Fig. 6c).

(3) A prominent, heavily fractured zone, c. $10 \mathrm{~km}$ wide and trending roughly $\mathrm{N}-\mathrm{S}$, approximately colinear with a major Caledonian fault in the area north of Scoresby Sund. This may represent an abortive location of break-up, used by the earlier basalt formations before an eastwards jump to the present margin (Larsen, L.M. \& Watt 1985).

(4) A local point source uplift c. $50 \mathrm{~km}$ inland where lavas are fragmented into blocks dipping centripetally. This structure, although larger, is perhaps similar to the one described by Matthews (1979) in the Watkins Bjerge area, which he thought might represent the roof of an unexposed intrusive body.

(5) A half-graben preserving mildly alkaline basalts (Igtertivâ Formation) above the main lava pile in the northern Blosseville Kyst area.

(6) A structurally complex zone of tilted blocks paralleling the coast but inland of feature 2 and bordered by feature 5 to the north-west.

(7) The Kangerlussuaq dome as originally recognised by Brooks (1979), now heavily dissected, but with eroded basaltic flanks still reaching up to $c .3700 \mathrm{~m}$ altitude.
Naturally, flows vary considerably in thickness and morphology, a fact helpful to mapping. Thus distinct packages of flows, identifiable by characteristic thicknesses, colours etc., can sometimes be followed from nunatak to nunatak. In general, these flows are simple flows in the sense of Walker (1972), implying very much higher extrusion rates than for the largely compound flows of the underlying Lower Basalts (Figs 5b, 6b). Nevertheless, compound flows do occur, as do limited hyaloclastites, especially in the north where flows have filled valleys in the underlying gneisses. Some hyaloclastites also occur in the uppermost lavas (Skrænterne Formation) that may have formed in lakes. Red boles (fossil soil horizons, Fig. 6d) are not common except towards the top of the pile, reinforcing the observation from radiometric dating and biostratigraphy that the eruptions followed each other rapidly, only slowing towards the top of the succession. Likewise, intrabasaltic sedimentary rocks have only been found close to the top of the succession. Their marine fossils (Fig. 6e) show that the thickening of the lava pile was balanced by deepening of the basin. Common textures are aphyric to microphenocrystic, although many flows with large phenocrysts of plagioclase, often forming star-shaped aggregates, are quite common. Vesicular flow bases and pipe amygdules are common (Fig. 6f). Picrites are relatively rare compared to the Lower Basalts and the overlying Prinsen af Wales lavas.

\section{Stratigraphy}

The stratigraphy of the Main Basalts (Fig. 3) was originally established in the Scoresby Sund area by Larsen, L.M. et al. (1989) after many years of detailed field and laboratory work. Mapping of the basalts requires sophisticated techniques as flows can rarely be followed far and marker horizons are few, with the exception of the distinctive Hjørnedal marker horizon (Larsen, L.M. et al. 1989). Otherwise, correlations are established by distinctive flow packages and backed up by sampling on a flow-by-flow basis and chemical fingerprinting. Certain lava types and successions of types may have quite distinctive chemical characteristics. This work established six formations, of which two, Magga Dan and Igtertivâ, are not regionally developed. As already mentioned, more recent work to the south has identified a seventh formation: the Nansen Fjord Formation, which is $c .1300 \mathrm{~m}$ thick in the Nansen Fjord area, 


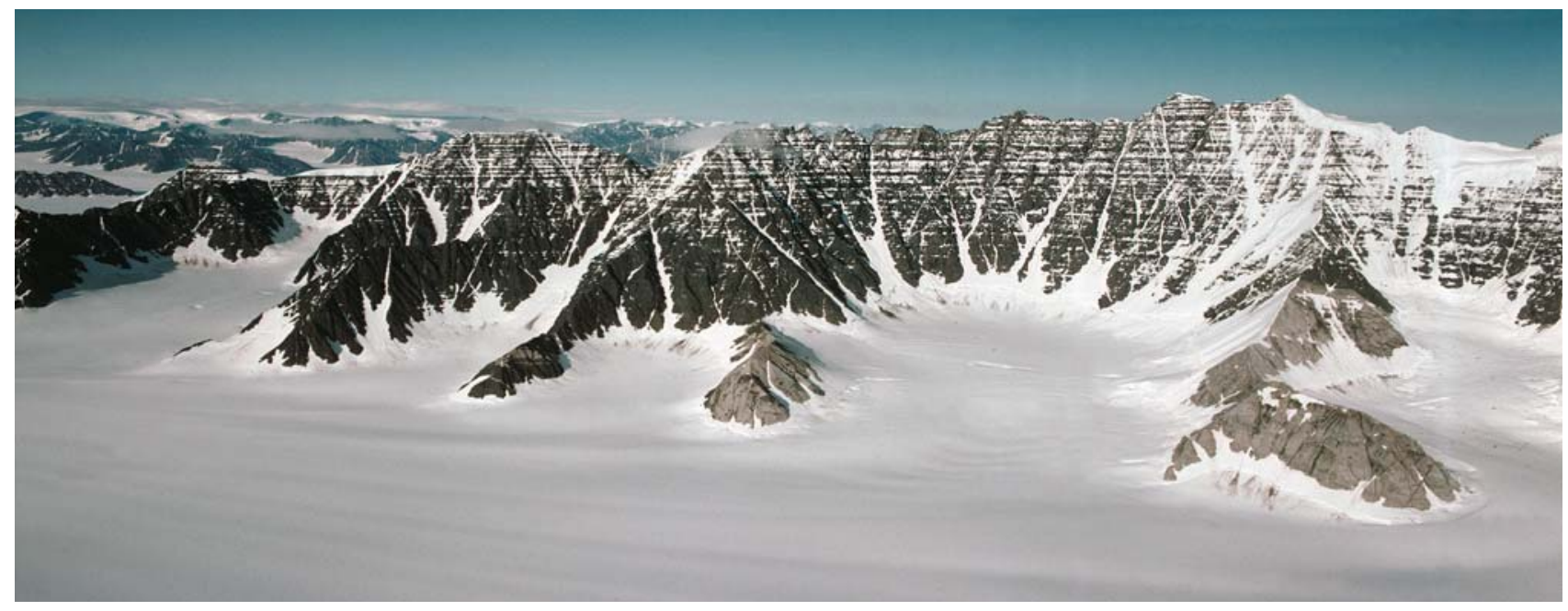

Fig. 6. Main Basalts. a: The basalts inland (height of wall about $1100 \mathrm{~m}$ ) at Borgtinderne intruded by the Borgtinderne syenite in the lower spurs (Brown et al. 1978). Here, the flows are almost horizontal, lacking the seaward dip (the coastal flexure) seen in coastal areas.

\section{Facing page:}

b: Cliffside in Miki Fjord (height $c .500 \mathrm{~m}$ ) showing massive appearance of basalts due to incipient metamorphism. Photo from Eskimonæs by A.A. Garde. c: Cliff in Rømer Fjord typical of the Main Basalts, viewed towards north. The dip of the lava flows is due to the coastal flexure. Both simple flows (thick, rusty-coloured units) and compound flows (thinly bedded, greyish brown units - at upper right) are present. Dykes (arrows), approximately perpendicular to the flows and with bleached margins dip inland, also as a result of the flexure. Height of cliffside $c .100 \mathrm{~m}$. d: Detail of a red bole (fossil soil horizon, possibly weathered tephra) and the overlying basalt flow at Kap Dalton, with chilled lower contact of the flow and lower part of colonnade (prismatically jointed) zone. The author for scale. e: Specimen of the crab, Coeloma bicarinatum, a distinctive Eocene fossil from the post-basaltic Kap Dalton Formation (sample $9 \mathrm{~cm}$ across). f: Lower part of a basaltic flow unit showing vesicular base and pipe amygdales above. White material is zeolite. g: Main Basalts at Wiedemann Fjord, little affected by flexuring. They are cut by a large dyke filled with hydrothermally deposited minerals, mainly calcite with minor copper sulphides. Note its continuation in the distant mountains (arrow).

but which is now assigned to the Lower Basalts. It is divided from the overlying Milne Land Formation by a prominent sedimentary horizon that itself rests on Paleocene sedimentary rocks or gneisses inland. This horizon can be correlated to the Faroe Islands (Larsen, L.M. et al. 1999 - see also Søager \& Holm 2009). The relationship of the Nansen Fjord Formation, from where it was established to the east of Nansen Fjord to the exposures on the western side of Nansen Fjord, is unclear, and thus there is a corresponding lack of clarity regarding the precise relationships of the succession to the underlying Lower Basalts on each side of the fjord. Radiometric dating suggests a substantial hiatus of several million years but not yet clearly defined.

According to Larsen, L.M. \& Watt (1985), the Main Basalts comprise two major cycles. The lowest and variable Milne Land Formation is succeeded by the relatively uniform Geikie Plateau Formation. Above this comes the variable Rømer Fjord Formation and, above this, the uniform Skrænterne Formation. This division at the base of the Rømer Fjord Formation was also apparent in the work of Tegner et al. (1998a) where it was seen to signal a change in the melting regime. The main difference between the two cycles is that the lower one is largely quartz normative, while the upper is overwhelmingly olivine normative, suggesting reduced crustal influence with time.

In the Scoresby Sund area and inland, the basalts rest on Precambrian or Caledonian gneisses where a considerable palaeo-topography of $c .300 \mathrm{~m}$ exists (seen in fig. 5 of Larsen, L.M. et al. 1989). This relationship is perhaps best seen in Gasefjord and Føhnfjord in the interior of the Scoresby Sund fjord system (Fig. 2), where the underlying rocks are the Krummedal paragneisses of the Niggli Spids and Hagar Bjerg Caledonian nappes and the Precambrian foreland (Higgins et al. 2004). 

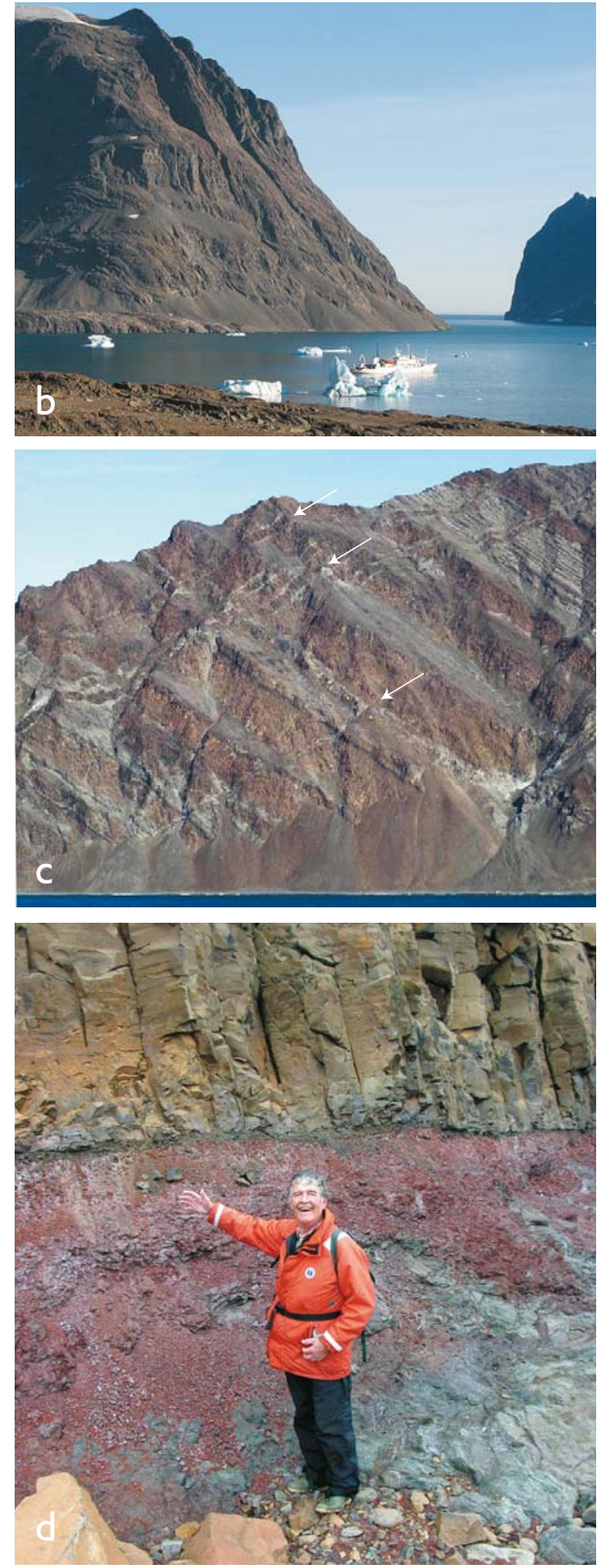
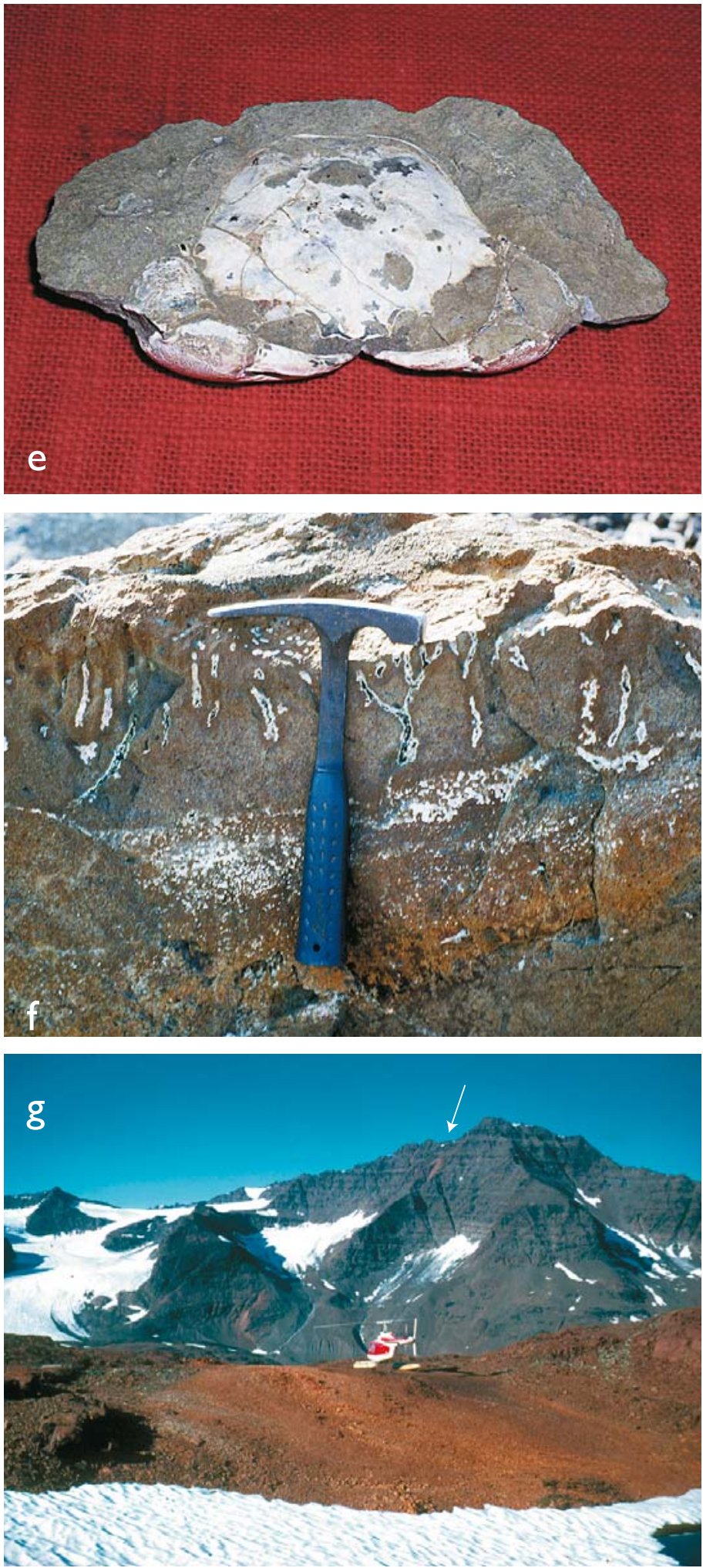


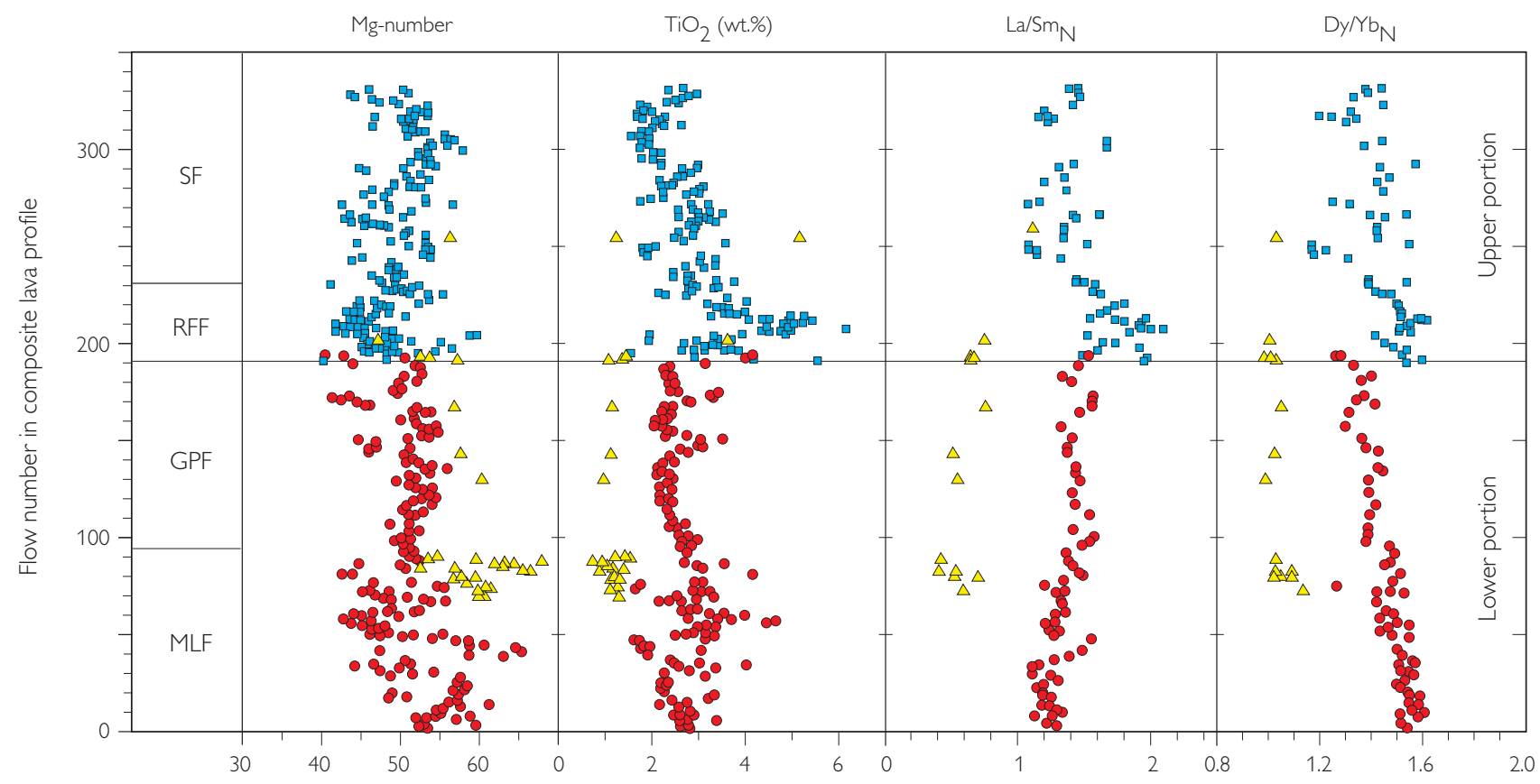

Fig. 7. Chemical stratigraphy of the Plateau Basalts based on 331 flows covering a vertical section of 6 km. Red symbols: lower unit of high-Ti lavas. Blue symbols: upper unit. Yellow symbols: low-Ti lavas. From Tegner et al. (1998a); reprinted by permission from Nature, Macmillan Publishers.

\section{Composition and genesis}

The predominant composition of the lavas is described as high- $-\mathrm{TiO}_{2}$ ferrotholeiites. Picrites also occur in minor amounts, often found in certain horizons, besides orthopyroxene-phyric ankaramites interpreted as products of magmas contaminated with continental crust (Gras et al. 2004) and low- $\mathrm{TiO}_{2}$ flows interpreted as similar to MORB. In general, it seems that the lowermost part of the post-break-up succession is most variable.

In the Sydbræ area of Scoresby Sund, a nephelinite tuff, up to $12 \mathrm{~m}$ thick, was identified by Larsen, L.M. et al. (1989) at the base of the Rømer Fjord Formation. As it does not occur in other profiles, it is probably quite local; Larsen, L.M. et al. (1989) stated that it covers $20 \mathrm{~km}^{2}$. This and a thin sanidine-bearing tuff in the uppermost Skrænterne Formation are unique as all other extrusives in the Main Basalts are tholeiitic, except for the uppermost, very restricted, Igtertivâ Formation which is poorly characterised but known to include some alkaline flows. The sanidine-bearing tuff at Skrænterne is thought to be sourced in the Gardiner complex (Fig. 2) and is extremely extensive, and has proved useful for radiometric dating (Heister $e t$ al. 2001 and see below).
Tegner et al. (1998a) showed that the Main Basalts can be divided into minor, low-titanium flows (0.82-1.96\% $\mathrm{TiO}_{2}$ ), those which resemble MORB, and high-titanium flows (1.63-6.18\% $\left.\mathrm{TiO}_{2}\right)$ - a type that is widespread in the North Atlantic Igneous Province. Their key diagram is reproduced here as Fig. 7. The former type, regarded as being MORB-like, was thought to reflect the early phases of sea-floor spreading, while the latter group has been subdivided into a high-Ti group and a very high-Ti group. Two major units make up the sequence (Fig. 7). Tegner et al. (1998a) discussed a genetic model in which the high-Ti lavas of the Milne Land and Geikie Plateau Formations were produced by segregation at decreasing temperatures whereas those of the Rømer Fjord and Skrænterne Formations segregated at near-constant temperature but over a wide range of pressures. Alternatively, the low-Ti lavas, which resemble mid-ocean ridge basalts, may simply have originated in local, depleted regimes of the mantle rather than being sourced at a true ocean ridge. In any case, their presence shows that the source region for the Main Basalts was heterogeneous.

Andreasen et al. (2004) made a flow-by-flow study of the relatively homogeneous Geikie Plateau Formation, identifying fractional crystallisation as the dominant process of variation and proposing a model for 
the plumbing system. Contamination by amphibolitefacies gneiss in the main flows and granulite-facies gneiss in the evolved flows was minor, but indicated that the differentiation took place in relatively shallow magma chambers. They suggested that these lavas are contemporaneous with the Skaergaard intrusion, although Peate, D.W. et al. (2008), in an extension and refinement of this study, pointed out that $\mathrm{Pb}, \mathrm{Nd}$ and $\mathrm{Sr}$ isotopic data indicate that the Skaergaard magma is more contaminated with crust. This correlation was later used in an estimate of the timing of the basalt extrusion relative to the Skaergaard intrusion by Larsen, R.B. \& Tegner (2006) as noted below.

Peate, D.W. \& Stecher (2003) studied a suite of least contaminated lavas representing the main types and determined their $\mathrm{Pb}$ isotopic signatures. They found that the samples were indeed minimally contaminated with continental crust, and that there was a correlation with type (e.g. ${ }^{206} \mathrm{~Pb} /{ }^{204} \mathrm{~Pb}$ increasing from low-Ti to very high-Ti, mirrored by $\left.\varepsilon_{\mathrm{Nd}}\right)$. They concluded that the East Greenland volcanics sampled source regions similar to those now being tapped in Iceland.

A comparison of the East Greenland basalts with those of Iceland was undertaken by Barker et al. (2006) to investigate in more detail the nature of the mantle sources being tapped through time. Many recent studies have shown that the Icelandic sources are heterogeneous (e.g. Thirlwall et al. 2004) and can be explained by mixing of several sources enriched and depleted in $\mathrm{Pb}$ and $\mathrm{Nd}$ space. Barker et al. (2006) found that indeed the Greenlandic lavas show similar components, although differing in detail, allowing the authors to make some inferences on the nature of the mantle plume, which they thought best explained the volcanicity.

Precious metals in East Greenland basaltic rocks were first investigated by Nielsen \& Brooks (1995), who found elevated levels in some rock types. Later, two detailed studies (Momme et al. 2002, 2006) catalogued the platinum-group element (PGE) behaviour in a representative suite of Main Basalts. Combining their PGE results with concentrations of rare-earth elements, they were able to show that the low-Ti lavas had formed by high degrees of melting (c. 20\%) in a cylindrical melting regime of the mantle, while the high-Ti lavas had formed from a more sulphur-poor source by lower degrees of melting (c. 6\%) in a mantle melting regime of triangular shape.

Three additional suggestions for the origin of the distinctive features of the Main Basalts (i.e. enrich- ment with respect to MORB basalts) should be noted. Bernstein et al. (2001) suggested that the enriched component in these basalts may represent melts of recycled ocean crust, which could be represented by the inland occurrences of melilitites and nephelinites (see below). Only $c$. $7 \%$ of the nephelinite needs to be incorporated into normal mid-ocean ridge basalt. The suggestion that recycled oceanic crust may be involved is, of course, favourable to the idea that formation of the basalts involved melting of a subducted slab, as contended by the opponents of the mantle plume hypothesis (Foulger et al. 2005). Gabbro signatures suggesting earlier subducted material have been identified at other postulated plume locations (e.g. Sobolev et al. 2000; Stroncik \& Devey 2011).

Studies by Hogg et al. (1988, 1989) and Larsen, L.M. et al. (1989) showed that substantial compositional variation within the basalts can be accounted for by refilling-tapping-fractionation processes as described by O'Hara \& Matthews (1981). Finally, in a study of the composition of likely primary melts, Korenaga $\&$ Kelemen (2000) showed that the North Atlantic source regions have been heterogeneous in terms of $\mathrm{Fe} / \mathrm{Mg}$ ratios since the inception of activity up to the present day. Much compositional variation is thus attributable to variation in the source of the magmas.

\section{Radiometric ages and timing of volcanism}

Biostratigraphic methods relying on the pre-basaltic Ryberg Formation and the post-basaltic Kap Dalton Formation established that the basalts were emplaced in the interval between the latest Paleocene and the earliest Eocene (Soper et al. 1976a, b). At that time, radiometric dating was difficult and results inspired little confidence. Worse, there was little chance of appraising the quality of the results. The only method available at that time was $\mathrm{K}-\mathrm{Ar}$ and this suffered from variable and indeterminate $\mathrm{Ar}$ loss from altered material (probably mesostasis glass). In other cases, excess $\mathrm{Ar}$ was present (i.e. some ${ }^{40} \mathrm{Ar}$ had been present from the start, due to imperfect degassing). The first K-Ar results were reported by Beckinsale et al. (1970) and later by Noble et al. (1988), not only on basalts, but also on the intrusions (see p. 13). Results spread so widely that little conclusion could be reached except that the basalts were Paleocene/Eocene, and this was already known from biostratigraphy. 
The ${ }^{40} \mathrm{Ar} /{ }^{39} \mathrm{Ar}$ method is both more accurate and allows an appraisal of the quality of the results using internal checks (e.g. nature of plateau age, correspondence between plateau and isochron ages, approach to atmospheric values for common $\mathrm{Ar}$ ). Its main weakness is that it relies on calibration to known samples rather than yielding an absolute age as do $\mathrm{U}, \mathrm{Th}-\mathrm{Pb}$ methods. The first attempt to use the ${ }^{40} \mathrm{Ar} /{ }^{39} \mathrm{Ar}$ method was undertaken by Hansen et al. (1995) with some, but limited, success. Extensive ${ }^{40} \mathrm{Ar} /{ }^{39} \mathrm{Ar}$ studies (Storey et al. $2007 \mathrm{a}, \mathrm{b})$ show that the age range of the Main Basalts is $c .58$ to $55 \mathrm{Ma}$; results are shown in Fig. 3. The lower age is corroborated by a date of $c .55 \mathrm{Ma}$, reported by Heister et al. (2001), for the sanidine-bearing tuff near the top of the Skrænterne Formation (Fig. 3), which is the same as that obtained by Storey et al. (2007a) on the same material. The age data show that the basalts were extruded at around the time of continental break-up in this area, consistent with the presence of magnetic anomaly $24 \mathrm{r}$ offshore and the occurrence of MORBtype lavas within the succession. As noted previously, chron $24 \mathrm{r}$ is centred at $c .56 \mathrm{Ma}$ with a duration of $c$. $3 \mathrm{Ma}$ (Westerhold et al. 2007). The sequence from the lowest Milne Land Formation to the uppermost Skrænterne Formation extends from $56.1 \pm 0.5$ to $55.0 \pm 0.4$ $\mathrm{Ma}$, confirming the suspicion that this $>6 \mathrm{~km}$ thick sequence of lavas was erupted very rapidly, as has been found in other large igneous provinces (e.g. the Deccan: Chenet et al. 2007; Yemen-Ethiopia: Coulie et al. 2003). Unfortunately, the results do not rigorously define the length of the hiatus marked by the sedimentary/pyroclastic horizon at the base of the Milne Land Formation, and which is present as coal and volcaniclastic rocks in the Faroe Islands. Two samples from the underlying Nansen Fjord Formation give $56.8 \pm 2.3$ and $57.7 \pm 0.05 \mathrm{Ma}$. Combined with determinations from the Urbjerget Formation (Hansen et al. 2002) and the Faroese Lower Series (Storey et al. 2007a, b), the age of the Lower Basalts in East Greenland is $c .60$ to $c .57$ $\mathrm{Ma}$, and the earliest Milne Land Formation flows are c. $56 \mathrm{Ma}$. The best estimate for the length of the hiatus is only $c .1 \mathrm{Ma}$, but this may yet be revised as no study has specifically focused on this problem.

Storey et al. (2007b) discussed the rate of magma production in the East Greenland -Faroe sector of the North Atlantic Igneous Province. They showed that volcanism began at $61 \mathrm{Ma}$ and continued to just after $57 \mathrm{Ma}$ over an area $2000 \mathrm{~km}$ across from Baffin Island to Britain. This early stage is represented by the Lower Basalts. An average production rate of $163 \mathrm{~km}^{3} / \mathrm{Ma}$ per kilometre of rift length was estimated (allowing for estimated underplated and intruded material), although this decreased slightly with time. After the volcanic hiatus at the base of the Milne Land Formation in East Greenland and the base of the Middle Series in the Faroes, this value jumped to $3000 \mathrm{~km}^{3} / \mathrm{Ma}$ per kilometre of rift length, later decreasing to half of this. Essentially, this is in agreement with the seismic results from offshore East Greenland reported by Holbrook et al. (2001), based on the traverses shown in Fig. 1. Storey et al. (2007b) considered models of edge-driven upwelling, meteorite impact and start-up mantle plume to explain these amazing rates of magma production and concluded that only the plume model is a likely explanation.

In a novel argument, Larsen, R.B. \& Tegner (2006) used estimated pressures in Skaergaard gabbro pegmatites to show how the thickening of the overlying plateau basalts had taken place during the evolution of the Skaergaard intrusion, confirming the very rapid rate of several kilometres of lava extrusion, perhaps taking as little as 300000 years. Note that red boles (or intra-flow weathered tephras), which indicate substantial periods between eruptions, are rare in the lower parts of the Main Basalts, although specific observations are undocumented. That shown in Fig. $6 \mathrm{~d}$ is near the top of the pile when extrusion rates were apparently waning. Sporadic palaeomagnetic observations (Tarling et al. 1988; Abrahamsen \& Nordgerd 1994) also supported a rapid extrusion, as all the lavas examined so far are reversely magnetised and were therefore probably emplaced during magnetochron C24r. According to Westerhold et al. (2007), who used astronomical tuning in addition to radiometric methods, magnetochron C24r lasted 3.118 $\pm 0.05 \mathrm{Ma}$. Note, however, that palaeomagnetic studies only cover a short section of the pile.

There are now reliable radiometric ages for the Main Basalts and also for the sanidine-bearing tuff in the Skrænterne Formation (shown in Fig. 3). Heister et al. (2001) argued that this tuff is represented at many distant sites including Deep Sea Drilling Project Site 550, where it occurs just above the Paleocene-Eocene Thermal Maximum, albeit with an intervening hiatus in deposition. Passey \& Jolley (2009) suggested that the Nansen Fjord Formation and its equivalent in the Faroe Islands post-date the Paleocene-Eocene Thermal Maximum. This could possibly be true, although the dating and rates of lava extrusion still lack the necessary precision and accuracy to support this. Larsen, R.B. \& Tegner (2006) estimated that 5.3-6.3 \pm 2.7 $\mathrm{km}$ of basalt stratigraphy were produced in less than 
300000 years, while Westerhold et al. (2007) estimated that 672000 years had elapsed between the inception of the Paleocene-Eocene Thermal Maximum and ash layer -17 in Denmark, which is correlated to the sanidine-bearing tuff layer at the top of the Skrænterne Formation. Thus the entire $c .7 \mathrm{~km}$ of lava could easily have been formed in this interval. However, Storey et al. (2007a), relying on their radiometric dates, especially for the sanidine-bearing tuff originally dated by Heister et al. (2001), place the Paleocene-Eocene Thermal Maximum in the Geikie Plateau Formation and the associated carbon isotope excursion around the top of the Milne Land Formation. On a separate, but related note, the claim by Jolley et al. (2002) that the geological time scale for the Palaeogene is seriously in error should be ignored for the reasons stated by Aubrey et al. (2003), Wei (2003) and others.

The long-standing question as to the possible connection between the Paleocene-Eocene Thermal Maximum and volcanism in the North Atlantic region (e.g. Svensen et al. 2004, 2010; Hansen 2006) is very significant in the light of the present interest in the climatic changes and will be addressed below. The best estimate range for the age of the Paleocene-Eocene Thermal Maximum is currently 55.964 to $55.728 \mathrm{Ma}$ (Charles et al. 2011).

\section{Zeolite zones}

Zeolites were reported by Fawcett et al. (1973) and Larsen, L.M. et al. (1989), but the most comprehensive treatment was presented by Neuhoff et al. (1997). They recognised the following zones with depth: no zeolites ( 0 to $c .400 \mathrm{~m}$ ), chabazite + thompsonite (c. 400 to $c$. $1400 \mathrm{~m}$ ), analcime (c. 1400 to $c .1600 \mathrm{~m})$, mesolite + scolecite $(c .1600$ to $c .2250 \mathrm{~m})$, heulandite + stilbite $(c$. 2250 to $c .2500 \mathrm{~m}$ ) and laumontite (down to $c .2650$ $\mathrm{m})$. Below this, prehnite $+\mathrm{K}$-feldspar + quartz are stable. They correlated these zones with similar ones in Iceland and were able to set temperatures on the different isograds that are consistent with a geothermal gradient of c. $40 \pm 5 \% \mathrm{~km}$. Detailed mapping showed that zeolite isograds transgress the stratigraphy but are earlier than both plutons and the dyke swarm, and reflect synvolcanic deformation. The lack of zeolites in the uppermost $400 \mathrm{~m}$ suggests that the top of the lava pile inland is close to the original palaeosurface, i.e. erosion has been minimal here.

\section{Comments on the plume hypothesis}

Since the present author first proposed the application of the plume hypothesis to the area (Brooks 1973), numerous attempts have been made to confirm this idea, but in spite of all the information now available, the question is still unanswered. Most workers agree that there are close ties between the East Greenland Main Basalts and modern Icelandic lavas, in particular evidenced by the similar isotopic signatures. It is still the consensual opinion that the vast outpourings of lava over a very short period and the continuing activity over close to $60 \mathrm{Ma}$ are best explained as the result of a plume, where the initial huge outpourings represent a mushroom-like head, and continuing activity in Iceland is sustained by the plume stem, following the classic model of Campbell \& Griffiths (1990).

It should be remembered that when the plume theory was first discussed in the early 1970s, the internal structure, composition and age distribution of flood basalt provinces were poorly known, such provinces not then being attractive research targets. The plume hypothesis changed this situation radically, and large igneous provinces rapidly became a major focus of earth scientists. Nevertheless, such provinces remain enigmatic and are not explained by standard platetectonic scenarios. Furthermore, the suggestion that plumes have been associated with global extinctions as championed by several workers (e.g. Eldholm \& Thomas 1993; Courtillot 2002) has gained increasing support and attracted researchers from many fields. East Greenland, with its outstanding exposure of part of one of the Earth's largest igneous provinces, represents an unequalled opportunity for the study of this hypothesis.

\section{Late basalts and sedimentary rocks (the Prinsen af Wales Bjerge Formation etc.)}

Originally described by Wager (1947) and Anwar (1955) and more recently by Hogg et al. (1988, 1989), Brown et al. (1996, 2000), Hansen et al. (2002) and Peate, D.W. et al. (2003), a series of variably dipping lavas occur in the nunataks of the Prinsen af Wales Bjerge (Fig. 2). They sometimes show angular discordance with the underlying plateau basalts and are thought to be late volcanic edifices unconformably overlying the plateau 
basalts. Lavas also occur on the Trekantnunatakker situated in the middle of Kangerlussuaq Gletscher (Fig. 2). However, Anwar (1955) and Peate, D.W. et al. (2003) showed that these lavas are partially intercalated with the uppermost plateau lavas. They suggested that there is no sharp transition between the Main Basalts and the overlying Prinsen af Wales Formation, the latter originating from more inland, central eruption sites, which became active as the production of the plateau lavas (Main Basalts) was waning.

These basalts are alkaline and often strongly olivineand pyroxene-phyric: very different from the underlying Main Basalts, which are tholeiitic and typically aphyric to plagioclase-phyric. Some of these flows are basanites and melanephelinites (Nielsen et al. 2001), representing the type of magma from which the Gardiner complex evolved. Several eruption sites have been identified accounting for the tilted flows, i.e. they are draping the sides of a volcanic edifice. On Lindsey Nunatak (west of the Prinsen af Wales Bjerge, Fig. 2), there are intervals of polymict conglomerates containing a variety of clasts, most notably some containing eudialyte, a mineral otherwise only known from the Gardiner complex (Nielsen 1989). Also on this nunatak, the Prinsen af Wales Bjerge lavas are overlain by picritic tholeiites whose affinity is unknown. There is some evidence that the sedimentary rocks here were deposited in rivers running west, perhaps down the side of the emerging dome (see geomorphology section).

Peate, D.W. et al. (2003) used Sm-Nd-Pb-Hf-Os-He isotopic data to show that the alkaline lavas are more radiogenic than typical Icelandic lavas and suggested they may contain recycled material (as has also been suggested by Bernstein et al. (2001) for the enrichment in incompatible elements in the Ti-rich lavas of the underlying plateau basalts).

Also overlying the plateau basalts in the northern coastal areas and of very limited extent is the Igtertivâ Formation (Larsen, L.M. et al. 1989), known only as downfaulted remnants in a half-graben at Kap Dalton on Blosseville Kyst south of Scoresby Sund (Fig. 2). Additional outcrops may be awaiting discovery elsewhere, as the area is little visited. Clearly, the Igtertivâ Formation was originally much more extensive. These lavas also include alkaline varieties.

Sedimentary rocks overlie the basalts unconformably at both Kap Dalton and Kap Brewster (Fig. 2). They have been described by Ravn (1904), Wager (1935), Birkenmajer (1972), Larsen, L.M. et al. (1989) and Larsen, M. et al. (2005). The lower of the two suc- cessions, formerly the Kap Dalton Formation, is now known as the Kap Dalton Group. This comprises the lower Bopladsdalen Formation (formerly the Cyrena Beds) and the upper Krabbedalen Formation (formerly the Coeloma Beds). These deposits provided a biostratigraphic upper limit of Ypresian to the plateau basalts (Soper \& Costa 1976). The basal conglomerate of the Bopladsdalen Formation contains clasts of a wide variety of strongly alkaline rocks of unknown provenance (Wager 1935). The Krabbedalen Formation contains a rich, shallow marine fauna estimated to be of Lower Oligocene age (for an example see the crab in Fig. 6e). Of probable Miocene age is the very restricted Kap Brewster Formation, which has a basal breccia suggesting proximity to a major fault and thus providing evidence of tectonic movements sometime between the Eocene and Miocene. Larsen, M. et al. (2005) carried out a rather exhaustive study which includes details of earlier work. They concluded that the Kap Dalton Formation was formed in a limited period in the Middle Eocene (Chrons 21r to 20r) during transgression over a muddy shelf with two distinctive quartzitic sandstone units of unknown, but distal, provenance. Dating has been refined by palynological studies by Jolley (1998) to Early Eocene (52.5 Ma) for the Bopladsdalen Formation and Middle Eocene (c. 43 $\mathrm{Ma}$ ) for the Krabbedalen Formation. An Early Eocene age is different from the radiometric ages of the uppermost Main Basalts (Fig. 3), although the discrepancy, if not due to error, may be explained by longer-lasting volcanism in this coastal area.

\section{Miocene basalts}

As a result of detailed field work in 1995, very young lavas were unexpectedly found in a small area to the north of the Borgtinderne intrusion (Fig. 2) overlying the plateau lavas and occurring as remnants capping nunataks. Named the Vindtoppen Formation, they have given $14-13 \mathrm{Ma}$ ages (Miocene) by the ${ }^{40} \mathrm{Ar} /{ }^{39} \mathrm{Ar}$ method (Storey et al. 2004). They are transitional to mildly alkaline with isotopic evidence of contamination by Archaean material. Melting of metasomatised mantle during regional uplift was tentatively suggested as the cause of this volcanism, but its relations to the overall development of the margin remain obscure. 


\section{Offshore basalts}

Seaward-dipping reflectors (Hinz et al. 1987) were first imaged seismically along many continental margins and interpreted as tilted lava flows - an interpretation later confirmed by drilling. Seaward-dipping reflectors are characteristic of so-called volcanic margins, of which East Greenland is a prime example (Larsen, H.C. \& Jakobsdóttir 1988): They are present over most of the margin. In addition, large areas of the shelf are covered with basalt extensions from onshore (Fig. 1). The Ocean Drilling Program drilled the basaltic basement on legs 152 and 163 (Larsen, H.C. \& Saunders 1998), sampling such reflectors. Locations of these sites are shown in Fig. 1, with shelf sites 915, 917 and 918 located on the landward feather-edge of the seawarddipping reflectors. At site 917, $779 \mathrm{~m}$ of basalt were penetrated, and a sequence of steeply dipping, metamorphosed sandstones and siltstones was reached (Vallier et al. 1998). These sedimentary rocks are of unknown age, but lithologically they are equated to the onshore Ryberg Formation. The volcanic stratigraphy was divided into three units: a lower series of continentally contaminated basalts with rare picrites, a middle series of more evolved, contaminated basalts, dacites and acid tuffs and, following a sandstone layer, an upper series of basalts and picrites of mid-ocean ridge affinity. At site 915, only a few metres of basalt were penetrated. At site 918, $235 \mathrm{~m}$ of the basaltic basement to the sedimentary rocks were sampled; a sill or flow within early Eocene sedimentary rocks lies $9 \mathrm{~m}$ above the basaltic basement. Werner et al. (1998) reported polymict breccias and conglomerates overlying the basalts at sites 917 and 918, perhaps equivalent to the Hængefjeldet Formation. Tuffs and lapillistones within the basalt formation yielded Ar-Ar ages of $60.5 \pm 0.2$ and $60.2 \pm 0.2 \mathrm{Ma}$.

On Leg 163 (Larsen, H.C. et al. 1999), holes at sites 989 and 990 supplemented the earlier holes and penetrated the basalts. They showed oceanic affinities similar to the upper series at sites 915 and 917. Unfortunately, Leg 163 was terminated early due to the ship being hit by a hurricane (ODP Shipboard Scientific Party 1996) and did not achieve its goals (which were: to complete the Leg 152 traverse and to drill an additional traverse closer to the plume source).

To summarise the offshore results very briefly: The recovered spectrum of compositions span a very wide range - approximately covering that of the entire North Atlantic Igneous Province. There is abundant evidence for the involvement of continental materials, not least the presence of acid rocks similar to those found on the eastern Atlantic margins (see Sinton et al. 1998 and references therein). As regards the oceanic rocks in the upper part of the sequence, there is some evidence that they formed in a cooler mantle than those closer to the supposed plume centre. Reliable radiometric ages are in the range 62 to $60 \mathrm{Ma}$ (Sinton et al. 1998; Werner et al. 1998). These lavas are subaerial and therefore most similar to the Lower Basalts. The sub-basaltic sedimentary rocks may be equivalent to the Kangerlussuaq Group. However, the onshore sedimentary rocks do not show the same high-angle unconformity with the overlying basalts and are unmetamorphosed. Although dacites and acid tuffs have not been found in the Lower Basalts, these are strongly contaminated with continental material (Hansen \& Nielsen 1999). On the basis of existing evidence, it is possible that thick dacite sequences only occur peripherally to the postulated plume head.

Tegner \& Duncan (1999) summarised results from the two East Greenland legs of the Ocean Drilling Program, which span $c .12 \mathrm{Ma}$ and fall into three mantle melting events. Pre-break-up continental volcanism occurred at $c$. 61-60 Ma, followed by syn-break-up volcanism c. $57 \mathrm{Ma}$ and post-break-up volcanism c. 49.6 $\mathrm{Ma}$. This was interpreted as heralding the arrival of the plume head under central Greenland, continental break-up and finally the passage of the plume stem beneath the East Greenland margin.

\section{Basalts of northern East Greenland}

Scattered outcrops of a Palaeogene lava succession occur between 73 and $76^{\circ} \mathrm{N}$ along the East Greenland margin, notably at Hold with Hope, Wollaston Forland and the island of Shannon, with a small outcrop on Traill $\varnothing$ (Fig. 8). Thick sills are also abundant in the sedimentary basins, both in the basalt areas and to the south, as in the Jameson Land Basin (Larsen, H.C. \& Marcussen 1992). The lavas, with extents shown in Figs 2 and 8 , have been described in a number of papers (Noe-Nygaard \& Pedersen 1974a, b; Hald 1978, 1996; Upton et al. 1980; Upton et al. 1984a; Upton 1988; Upton et al.1995; Ellam et al. 1998). The same area also includes the Myggbukta complex, a subvolcanic caldera complex, generally intensely hydrothermally altered (Upton et al. 1984b). Farther east, at Kap Broer Ruys, there is another probable central complex which 


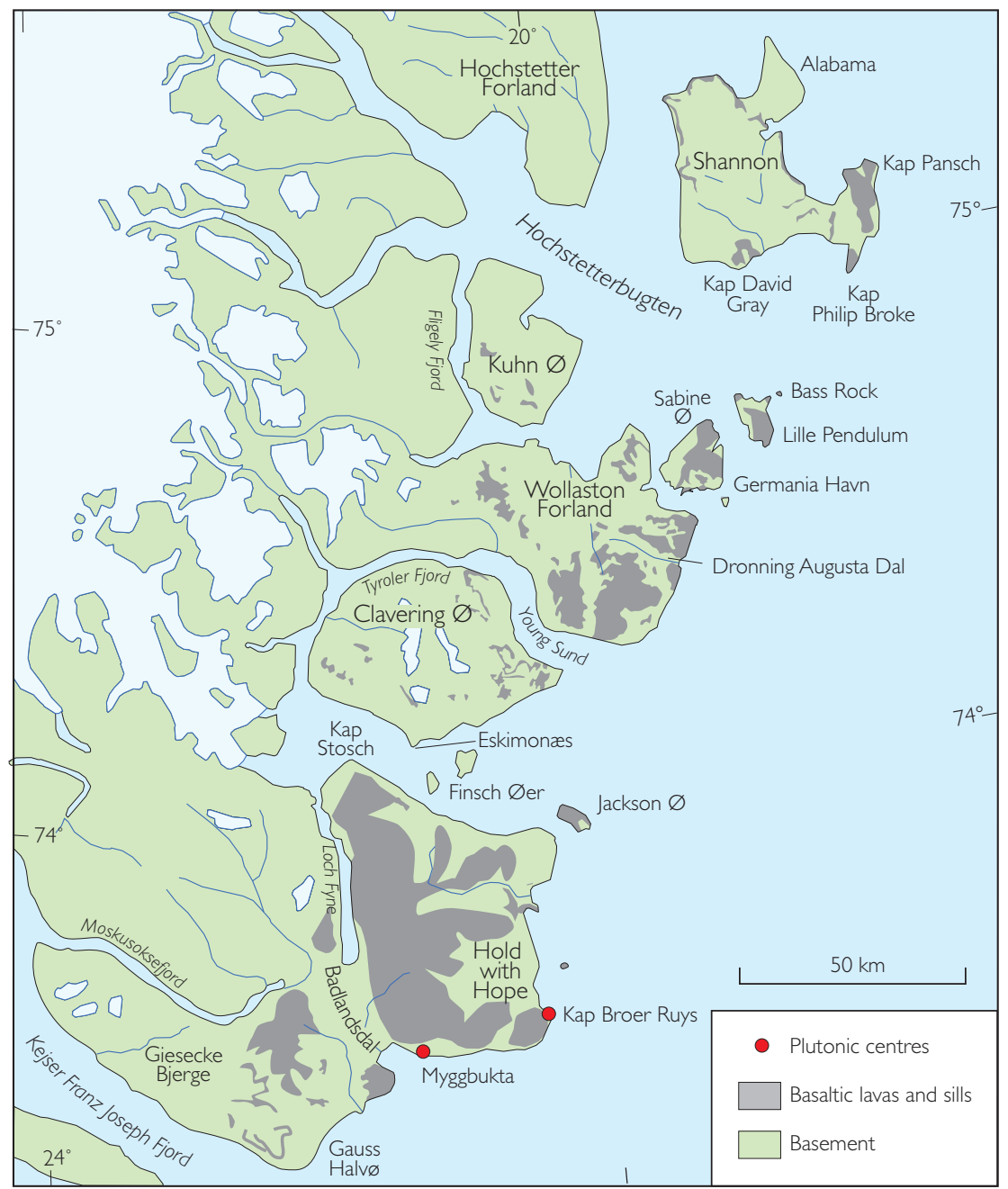

Fig. 8. Approximate extent of basic rocks in northern East Greenland, mainly basalts although some are extensive sills. Map compiled from references cited in the text. Two small, central complexes (Upton et al. 1984b) are also shown. Location shown in Fig. 2.

is not exposed apart from some minor granophyric and felsitic bodies.

The lavas are divided into two series: a Lower Series of $c .450 \mathrm{~m}$ and an Upper Series, c. $350 \mathrm{~m}$ thick. The Lower Series is quite uniform, aphyric to microphyric and consists of quartz tholeiites. Upton et al. (1995) suggested that these had been erupted far to the east, on the present Vøring Plateau off Norway during a massive burst of volcanic activity connected with the arrival of the Icelandic plume and continental breakup. Trace elements and isotopic ratios (Thirlwall et al. 1994) show little evidence of crustal contamination and there are close similarities to Icelandic basalts, as well as those of the Vøring Plateau. The Upper Series is much more variable, consisting of olivine tholeiites, alkali basalts and some basanites: They are commonly highly porphyritic and show evidence of interactions with subcontinental lithosphere. A much greater pro- portion of these magmas relative to the Lower Series was derived from garnet-facies mantle. These lavas are also thought to have been derived from a more local source than those of the Lower Series.

${ }^{40} \mathrm{Ar} /{ }^{39} \mathrm{Ar}$ dates on two dykes related to the Upper Series give values of c. 56.7 and $56.6 \mathrm{Ma}$, and an ankaramite flow gave $53 \mathrm{Ma}$, although this was thought to have suffered Ar loss. A basal nephelinite unit gave 58.7 Ma, but the possibility that this might be a sill cannot be ruled out (B. Upton, personal communication 1998).

The finding of elevated ${ }^{3} \mathrm{He} /{ }^{4} \mathrm{He}$ ratios (total range from $1.7 R_{a}$ to $21 R_{a}$, where $R_{a}$ is the atmospheric ratio) in some of these basalts is fully consistent with present interpretations of origin from a mantle plume (Marty et al. 1998). Similarly high ratios were reported by Bernstein et al. (1998b) for intrusions south of Scoresby Sund. 
Most of these lavas are roughly contemporaneous with the bulk of the lavas in the Kangerlussuaq Scoresby Sund area to the south and were erupted during magnetochron C24r, although part of the Upper Series may have erupted during the succeeding normal and reversed epochs. The most reliable age for the latest dyke swarm comes from a picritic dolerite sheet and is c. $33 \mathrm{Ma}$.

\section{Long-distance tephra falls}

The sanidine-bearing tuff in the uppermost part of the Skrænterne Formation was mentioned above and will also be discussed with respect to its age in the section below on nephelinites. Heister et al. (2001) argued, on the basis of its age, chemistry and highly distinctive mineralogy, that it had originated in the Gardiner complex. They further identified this ash in the diatomaceous Fur Formation in northern Denmark (in the Limfjorden area where it is well exposed on the islands of Fur and Mors; Brooks 2006) as the layer designated -17 . This is also of a distinctive alkaline composition, has identical rare-earth element patterns, contains unusual minerals like aegirine, katophorite and perovskite and is of the right age. The same ash occurs at several sites in the North Sea (e.g. Knox 1996) and was identified in Ocean Drilling Program site 550 on Goban Spur, south-west of Ireland. If the identification of Heister et al. (2001) is correct, it makes this tephra a very important stratigraphic marker. This is especially so as the eruption can be related to the Paleocene-Eocene Thermal Maximum, a short-lived warming event which has attracted much interest, especially as to its cause. The sanidine-bearing ash, which is designated as Layer -17 , has been dated by a number of workers using the ${ }^{40} \mathrm{Ar} /{ }^{39} \mathrm{Ar}$ method (see Westerhold et al. 2009 for a summary) in an attempt to accurately date the thermal maximum and to refine the geological time scale, including the Cretaceous-Paleocene boundary. Astronomical tuning (which involves identifying and counting Milankovich cycles, whose durations are known) in sedimentary rocks of this part of the succession indicates that the ash of Layer -17 post-dates the thermal maximum by $672 \pm 21 \mathrm{ka}$.

The Fur Formation is characterised by c. 180 ash layers, mostly of a high-titanium ferrobasalt type, similar to many in East Greenland and the Faroe Islands. All these ashes have also been studied in de- tail by Larsen, L.M. et al. (2003), who defined their compositions and attempted to deduce their source areas. Some other layers (particularly those designated $-11,-12$ and -13$)$ are similar to the alkali basalts in the upper part of the East Greenland succession. Larsen, L.M. et al. (2003) concluded that the lower Fur ashes stem from the general East Greenland area, but later, more voluminous ferrobasaltic ashes originated from the already submerged, evolving rift between East Greenland and the Faroe-Rockall area: the site of the postulated Icelandic protoplume. The correlation of Layer -17 and nearby highly alkaline ashes with the Gardiner complex was only tentatively accepted.

Another prominent ash layer in the Danish succession is labelled +19 and is also a potentially important stratigraphic marker. This is a thick, peralkaline rhyolitic ash, postdating the Paleocene-Eocene Thermal Maximum by $862 \pm 21 \mathrm{ka}$ according to astronomical tuning (Westerhold et al. 2009). The source of this ash could not be identified by Larsen, L.M. et al. (2003), but similar compositions are found in East Greenland and, indeed, in Iceland, although the Icelandic ones are much younger and cannot be a source. This ash, which was also identified in Austria by Egger \& Brückl (2006), was estimated to have a total volume of $1200 \mathrm{~km}^{3}$, placing it among the largest volcanic events known. Some basaltic ash layers were estimated to have volumes of $c .500 \mathrm{~km}^{3}$, whereas many are $c .120 \mathrm{~km}^{3}$, which makes them similar in volume to the largest historical eruption (i.e. Tambora).

It should be noted that the lower part of the Danish ash series is dated by the -17 ash to be contemporaneous with the uppermost Skrænterne Formation, so the bulk of the ashes (in the positive series, mostly basaltic) must have been erupted after the East Greenland Main Basalts. Likewise, they cannot have come from the Faroe Islands or Britain as volcanic activity in these areas had ceased at this time (at least, on the basis of the presently known geology). The conclusion is that these eruptions took place after continental break-up, in areas now located offshore, in agreement with the conclusions of Larsen, L.M. et al. (2003) as described above. They record well over 100 truly vast eruptions. Egger \& Brückl (2006) estimated that the 23 ash layers they identified in Austria represent a total eruption volume of $c .5000 \mathrm{~km}^{3}$. 


\section{Gabbroic intrusions}

\section{The Skaergaard intrusion}

Although only a superficial description of research on the Skaergaard intrusion is given here, a brief overview is appropriate as many of the problems encountered in this intrusion also apply to the other gabbros of East Greenland. The history of research on the intrusion also provides an interesting insight into changing fashions, not to mention the difficulty in reaching a consensus on even the most basic questions in igneous petrology.

The intrusion was discovered by L.R. Wager on his first expedition to Greenland in 1930-1931, known as the British Arctic Air Route Expedition (Watkins 1932a, b, c; Brooks 1985b, 1990; Hargreaves 1991; Glasby 2007a, b). He not only recognised the scientific significance of the intrusion, but had the tenacity to overcome the immense difficulties of travel to East Greenland at that time, returning to overwinter in 1935-1936 (Wager 1937) and spending the year exploring a vast area by dog-sledge.

The early years of research on the Skaergaard intrusion were taken up with the basic description of its structure, mineralogy and composition as published by Wager \& Deer (1939). In the 1950s, the thrust of Wager's research was the mechanisms of the cumulus process, and a new visit to the intrusion took place in 1953. In the 1960s, emphasis moved to geochemistry as sensitive techniques for the determination of trace elements became available, and the distributions of a large number of elements were documented, largely by Oxford DPhil students, and the principles of their distribution in magmatic rocks determined.

No scientific visits to the intrusion took place in the period 1953-1970 when only prospectors visited the area. In 1971, groups from the University of Oregon and the University of Copenhagen were present, and a new research impetus emerged such that over the following years, researchers from several universities and other research institutions, particularly Stanford University, worked in the field. The main research during this time was in examining the cumulus theory of Wager, proposing other mechanisms, and the study of the hydrothermal systems of the intrusion.

Amazingly, it was not until 55 years after its discovery that the intrusion (and others nearby) was found to contain a world-class precious metal deposit (Bird et al. 1991, 1995; Arnason et al. 1997a, b; Arnason \& Bird 2000; Nielsen et al. 2005). In 1986, the Canadian company Platinova Resources Limited arrived and rapidly found gold anomalies in the Skaergaard intrusion, sparking a new phase of diamond drilling and the study of precious metals.

The Danish Lithosphere Centre initially targeted the volcanic succession, and it was not until the year 2000 that samples from the intrusions were collected. In that year, new comprehensive collections from the Skaergaard, Kangerdlugssuaq and other intrusions were made (Nielsen et al. 2001). In recent years, samples have also become available from commercial drill cores as well as from the 2000 collection. Work has been directed to revising the structure of the intrusion (Nielsen 2004), mainly using drill-core material. Subsequently, microtextural studies have been employed, with the aim of getting a better understanding of the processes taking place during the crystallisation of such rocks, by groups centered at Cambridge University (e.g. Holness et al. 2006, 2007, 2011; Humphreys 2009, 2011; Humphreys \& Holness 2010; McKenzie 2011) and at the University of Aarhus (Tegner et al. 2009).

The Skaergaard intrusion is not a large intrusion. It measures $11 \mathrm{~km}$ north to south, $8 \mathrm{~km}$ east to west, and is $3.4-4 \mathrm{~km}$ thick. Its volume is estimated to be 280 $\pm 23 \mathrm{~km}^{3}$ (Nielsen 2004). Originally, Wager \& Deer (1938) regarded its shape as being that of a funnel, but several alternative models have been proposed: laccolith, box-like, balloon-like (see Irvine 1992; Nielsen et al. 2005); no consensus seems to have emerged. However, it is agreed that the intrusion was filled fairly rapidly, and no further pulses of magma were added or extruded, so that differentiation took place in a closed system of a fairly normal type of tholeiitic magma.

The internal divisions of the Skaergaard intrusion are well known: the Marginal and Upper Border Series where magma has crystallised adjacent to the walls and roof, respectively, and the Layered Series. According to Wager \& Deer (1939), crystals in the latter series accumulated under the influence of gravity, leaving a clear record of changing magma compositions and forming gravity-generated structures such as layering with modal sorting, slumping cross-bedding and other features. Some of these are enigmatic, e.g. Christmas-tree-like dendrites (Fig. 11g) and the trough bands investigated in depth by Irvine \& Stoesser (1978).

Unfortunately, the promise of tracking magma variations from cumulate rock and mineral compositions turned out to be utopian. At least two views have 
emerged: the so-called Bowen trend, in which differentiation leads to silicic products, and the Fenner trend, where there is increasing iron concentration (see the controversy: Hunter \& Sparks 1987; Brooks \& Nielsen 1990; McBirney \& Naslund 1990; Morse 1990). The difficulty in determining the line of liquid descent is, of course, that we have no liquids and must extrapolate from the rocks. A further process that may be important in the development of basaltic magmas is liquid immiscibility, which was out of favour for many years but has now received renewed credibility (McBirney $\&$ Nakamura 1974; Naslund 1980; Jakobsen et al. 2005, 2010; Humphreys 2011). General agreement on these problems has not yet been reached.

Central to L.R. Wager's view of the intrusion was the sinking of crystals (primocrysts) in the magma under the influence of gravity, first adopted by Wager $\&$ Deer (1939) and later treated in detail by Wager et al. (1960) and in the book by Wager \& Brown (1968). This led to a completely new nomenclature as it was claimed that the primocrysts (cumulus crystals) in the rock could be distinguished from the intercumulus material, or trapped liquid. Various proportions of intercumulus material could be distinguished such that orthocumulates were rocks in which the cumulus crystals were from the instant of sedimentation, and the interstitial material trapped between the crystals would be equivalent to the magmatic composition at the time of deposition. At the other extreme, the intercumulus liquid had exchanged with the magma, and the primocrysts had overgrown to eliminate all the interstitial liquid, forming adcumulates. Mesocumulates lay in between these two end-members.

This entire view of cumulate rocks was later attacked, originally by McBirney \& Noyes (1979), but later also by other workers, who claimed that the primocrysts had grown in place against the walls and roof in boundary layers with strong concentration and temperature gradients where double diffusive convection was operative, and the magma chamber could split into separately convecting layers. This is an issue which still divides igneous petrologists, although it seems to have faded into the background in recent years. Irvine et al. (1998) showed that many structures in the Skaergaard Layered Series are undoubtedly gravity-derived and contend that crystals did sink, and there were convection currents.

Important studies were also conducted at the Skaergaard intrusion on the circulation of meteoric waters, beginning with the studies of Norton \& Taylor (1979),
Taylor \& Forester (1979) and Norton et al. (1984), and continuing with a large number of papers by a group from Stanford University (Bird et al. 1986, 1988; Manning et al. 1986, 1993, 1995; Manning \& Bird 1991). These studies extended to other nearby gabbros (e.g. Rose \& Bird 1987, 1984; Fehlhaber \& Bird 1991). Norton \& Taylor (1979) were able to present a detailed cooling model for the intrusion, which could be refined when accurate ages were obtained for minerals with different blocking temperatures.

For a long time, the age of the Skaergaard intrusion was poorly known. A fission track date indicated an age of $54.6 \pm 1.7 \mathrm{Ma}$ (Brooks \& Gleadow 1977), but this was not widely accepted due to the low repute of the method with traditional geochronologists. Subsequent ${ }^{40} \mathrm{Ar}-{ }^{39} \mathrm{Ar}$ ages on biotite were published by Hirschmann et al. (1997) giving $55.48 \pm 0.30$ and 55.40 $\pm 0.14 \mathrm{Ma}$ (plateau and isochron ages, respectively). Finally, U-Pb zircon dating of the Sandwich Horizon Rock (supposed to be the latest differentiate, sandwiched between the Layered Series and the Upper Border series) gave $55.59 \pm 0.13 \mathrm{Ma}$ (Hamilton \& Brooks 2004), and very high precision ages have recently been published for the sandwich horizon and the overlying Basistoppen sill (Wotzlaw et al. 2011).

Despite more or less continuous studies over more than 70 years, some of the fundamental questions related to such intrusions and igneous processes in general (e.g. the nature of the liquid line of descent, the importance of immiscibility (McBirney \& Nakamura 1974); the causes of igneous layering, the origin of precious metal concentrations) have not yet been answered satisfactorily (see e.g. Wilson 1993; Young 2003). Indeed, the concept of magma chambers is doubted by some; none of any size having been imaged seismically anywhere in the world (Dettrick et al. 1987; Lundstrom 2009).

The Skaergaard intrusion has many of the features shown by other gabbros in East Greenland (see below), but differs in some respects. It is the only body which crystallised as a closed system, i.e. the magma chamber was filled by a single pulse, and no extrusions of lava took place to the best of our present knowledge. Also, the magma developed on an unusual iron-rich trend, probably as a result of the closed system evolution. Finally, there are no ultramafic rocks as found in several other intrusions nearby (the so-called wehrlite suite). 

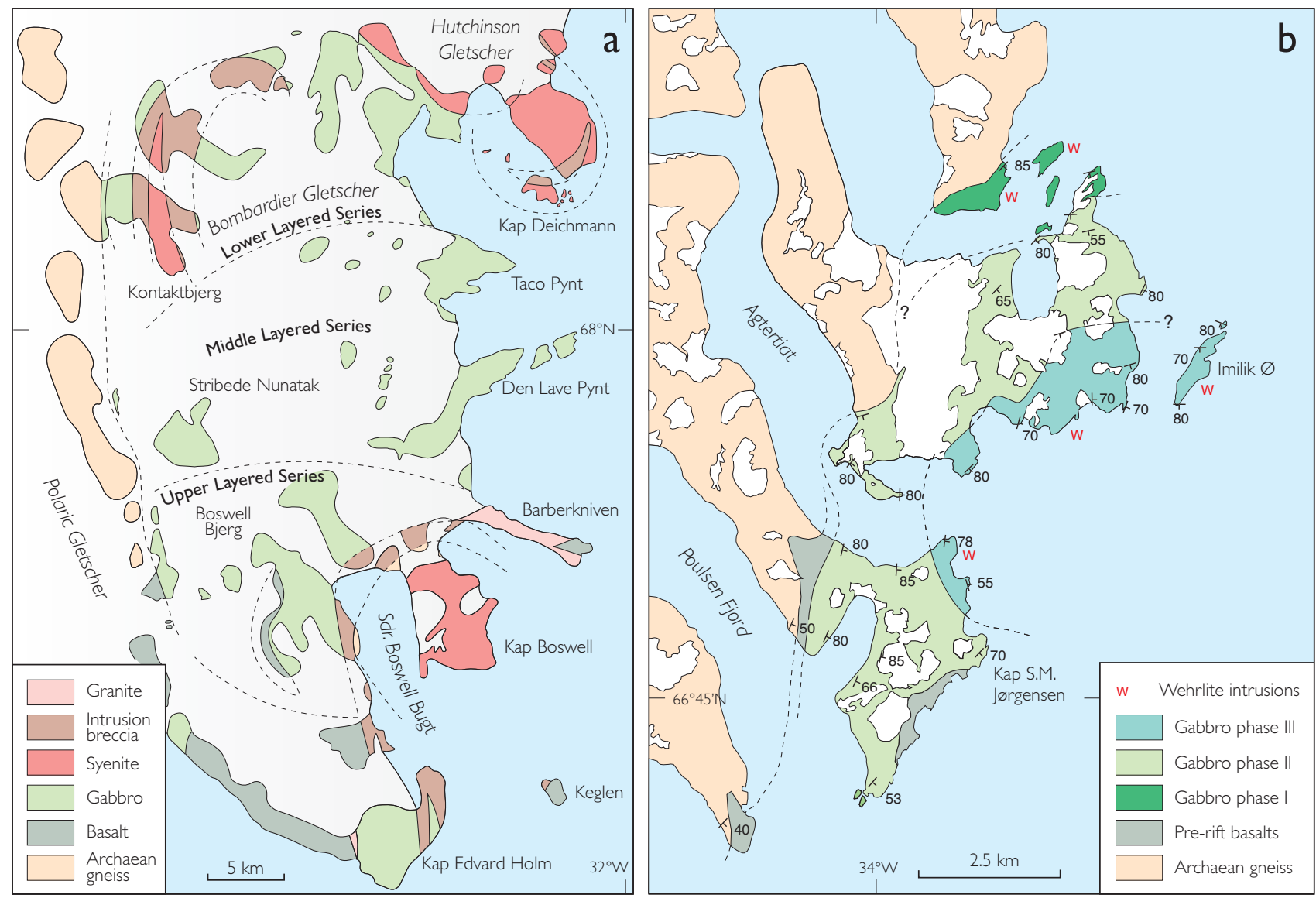

Fig. 9. Maps of two major intrusions. For locations see Fig. 2. a: Kap Edvard Holm complex. Map modified from Abbott \& Deer (1972). Geochronological data suggest a value of $c .49 \mathrm{Ma}$ for the Lower Layered Series and about $1 \mathrm{Ma}$ less for the Middle Layered Series. The satellite syenitic intrusions were described by Deer et al. (1984). b: Imilik intrusion (compiled from unpublished maps by S. Bernstein, D.K. Bird and C. Tegner).

\section{Other gabbroic intrusions}

In addition to the Skaergaard intrusion, gabbroic intrusions are ubiquitous throughout the area (Fig. 2). Notable examples are: Kap Edvard Holm (Elsdon 1969, 1971a, b, 1972, 1982; Abbott \& Deer 1972; Fehlhaber \& Bird 1991; Bernstein et al. 1992; Tegner \& Wilson 1993, 1995; Tegner et al. 1993; Brandriss et al. 1995; Bernstein et al. 1996; Brandriss et al. 1996; Tegner et al. 1998; Brandriss \& Bird 1999), Kærven (Ohja 1966), Kruuse Fjord (Arnason et al. 1997a, b; Tegner et al. 1998b), Imilik (Brown \& Farmer 1972; Tegner et al. 1998b) and the newly discovered Noe-Nygaard intrusion (Bernstein \& Bird 2000). Maps of the Kap Edvard Holm and Imilik gabbros are shown in Fig. 9. These are probably the two largest onshore gabbros in East Greenland, but both are imperfectly known. They are both made up of three main units of gabbro and include occurrences of wehrlite.

Several offshore gabbros are exposed only on small islands: Nordre Aputiteeq, Ittutarajik, Pattuulaajivit, Søndre Aputiteeq and an unnamed group of rocks informally known as 'The Skerries'. Their underwater extent, like that of Imilik, is unknown. These island gabbros give an insight into the nature of what must be very extensive gabbros on the shelf and are of considerable interest themselves. Some information has been published by Bernstein et al. (1998b) and Tegner et al. (2008), although many unpublished observations exist (e.g. Petersen 1977). Hitherto unpublished maps by D.K. Bird and N. Rose are given in Fig. 10.

The majority of these gabbros are tholeiitic. The gabbros of the Werner Bjerge complex and its satellites to the north (see below) are of alkaline character (Bearth 1959; Kapp 1960; Brooks et al. 1982), but there are 
no stable isotope studies from this northern area. Gabbro also occurs in the Myggbukta area of Hold with Hope. The timing of its emplacement has been discussed by Upton et al. (1984b). The Lilloise intrusion (Fig. 2) is reported to have been derived from an alkali basalt magma (Brown 1973). It is associated with large amounts of ultramafic rocks and under- to oversaturated minor syenitic bodies (Brown 1973; Matthews 1976; Brown et al. 1987; Chambers \& Brown 1995; Bernstein et al. 1998b; Tegner et al. 1998b). Recently, a new gabbro was described from the Kialeeq district (Bernstein \& Bird 2000), and named the Noe-Nygaard gabbro (see below). This intrusion contains wehrlites, as described previously for other gabbros of the area, which the authors explained as being generated by the dehydration of stoped, altered basalt xenoliths in accordance with previous studies.

The seminal oxygen isotope studies of Norton \& Taylor (1979), Taylor \& Forester (1979) and Norton et al. (1984) on the Skaergaard intrusion have already been mentioned, and a study of hydrogen isotopes in the gabbros and adjacent syenites of Kap Edvard Holm, Skaergaard and Nordre Aputiteeq led Nevle et al. (1994) to suggest that at between 55 and $43 \mathrm{Ma}$ these gabbros equilibrated with meteoric water flowing from the high altitudes existing inland at that time, due to the dome described by Brooks (1979). Sheppard et al. (1977) showed that, unlike all other studied gabbros of the North Atlantic Igneous Province, the Lilloise intrusion does not record the influx of meteoric water. Instead, the aureole has been altered by magmatic water flowing from the intrusion.

While documentation of all these bodies is far from complete, it appears that most are later than the Skaergaard intrusion and, in contrast to the latter, apparently display multiple fillings of magma chambers, such as has been clearly documented in the Lower Layered Series of the Kap Edvard Holm complex (Bernstein et al. 1992) or even multiple intrusions (e.g. Imilik as shown by Tegner et al. 1998b and Kap Edvard Holm). They appear to have been intruded in several time windows (Tegner et al. 1998b): 56-54 Ma, coeval with the bulk of the basalts (the Skaergaard intrusion, part of the Imilik intrusion and the Sorgenfri Gletscher sills - see below), 50-47 Ma (most of the remaining) and 37-35 $\mathrm{Ma}$ (mostly in the Mesters Vig and Kialeeq (Kialineq) areas - see below), which, as discussed by Tegner et al. (1998b, 2008), may also be the age of some of the latest lavas (with the exception of the Vindtoppen Formation). The oldest unit at Imilik (Tegner et al. 2008) has not been dated but is believed to have an age of $c$. $60 \mathrm{Ma}$ and thus coeval with the Lower Basalts and the earliest phase of activity throughout the North Atlantic Igneous Province. The intermediate unit is $>56.6 \pm 0.6$ $\mathrm{Ma}$ (age of a cross-cutting dyke), and the youngest unit has given ${ }^{40} \mathrm{Ar} /{ }^{39} \mathrm{Ar}$ ages of $50.1 \pm 1.2$ and $49.5 \pm 0.2$ Ma. It will be shown that these three ages coincide with main periods of magmatism in East Greenland, and the late age of many of the East Greenland gabbroic intrusions may reflect the passage of the East Greenland margin over the mantle plume stem, a suggestion also made by Bernstein et al. (1998b) based on rare-earth elements, $\mathrm{Sr}, \mathrm{Nd}$ and $\mathrm{He}$ isotopes.

Holm et al. (2006) published a zircon date for the Kærven gabbro, which is not completely concordant with the date provided by Tegner et al. (2008). However, both are considerably younger than the age of $c$. $58 \mathrm{Ma}$ inferred by Holm (1991), and the Kærven intrusion falls into the 56-54 Ma window.

The picture that has emerged of the timing of gabbro intrusions (and by extension probably also of surface volcanism) is a series of pulses at approximately 60 , 55, 49 and $35 \mathrm{Ma}$. These pulses seem to be separated by intervals of $c .5 \mathrm{Ma}$, except that a pulse at $c .40 \mathrm{Ma}$ is absent (but may be represented by some of the Mesters Vig gabbros). In Iceland, major rifting events involving rift jumps occur on an $8 \mathrm{Ma}$ time frame (Hardarson $e t$ al. 1997).

An interesting study of a gabbro plug at Courtauld Fjord (Bernstein 2006) included spot analyses of pyroxene crystals using electron microprobe and laser ablation ICP-MS methods. They showed that the compositions of the parent magmas (a long-standing problem when dealing with plutonic rocks) could be estimated using partition coefficients for many elements.

The Lilloise intrusion and its near surroundings were used as an example in a book by Mosely (1981) on field methods. The relevant chapter includes maps, photographs and methods used in the field, a discussion of the glacial deposits and a section on the basalts and dykes.

Spectacular layered features in the Skaergaard intrusion are known world-wide, and similar features occur in most of these gabbros. Figure 11 shows a selection of some typical structures encountered in East Greenland gabbros. These include various types of layering, such as macro- and inch-scale, wispy and cross-bedding (Fig. 11a), rhythmic, apparently gravity-controlled, slumped layers (Fig. 11b), layers deformed by settling autoliths (Fig. 11c) or rising diapirs (Fig. 11d, e) etc. In addition, 


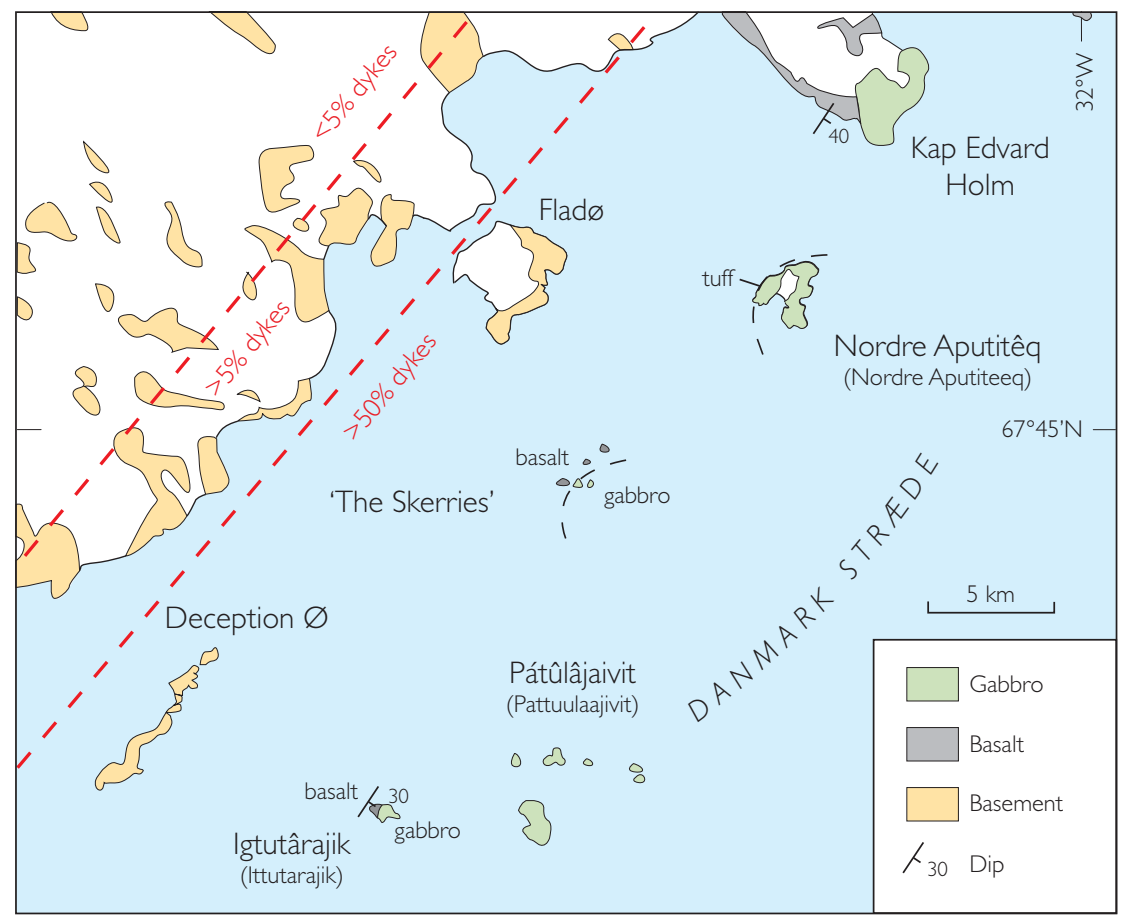

Fig. 10. Maps of gabbroic intrusions. For locations see Fig. 2. Left: Overview of intrusions on the islands and skerries to the south of Kap Edvard Holm, suggesting the extent of offshore gabbro. Facing page: Gabbros of the individual small islands south of Kangerlussuaq with ages of $c$. 50-48 Ma (Tegner et al. 1998b), compiled from unpublished maps by D.K. Bird and N. Rose (1987-1990). See caption to Fig. 2 and names in brackets for modern geographical spellings.

many other features, some perplexing, may be present. These include anorthositic autoliths or xenoliths and cross-cutting anorthosites (Fig. 11e, f), Christmas-treelike and other dendrites formed by plagioclase in the Skaergaard intrusion (Fig. 11g) formed by olivine (over $30 \mathrm{~cm}$ long) at Kap Edvard Holm (Tegner et al. 1998b) and by pyroxene and plagioclase in the Miki Fjord macrodyke (Blichert-Toft et al. 1992). Also areas of apparent pyroxenite replacement and other features have been described (e.g. McBirney \& Sonnenthal 1990; Sonnenthal 1992). The exposures on ice-polished surfaces are often exceptionally fine, making these rocks worthy and rewarding objects of study.

An additional impetus for research on the basic intrusions came with the discovery of very large and potentially economic amounts of precious metals in the Skaergaard intrusion (Bird et al. 1991; Andersen et al. 1997; Nielsen et al. 2005), closely followed by reports of precious metal occurrences in neighbouring gabbros (e.g. Bird et al. 1995; Arnason et al. 1997a; Arnason \& Bird 2000,) and the Miki Fjord macrodyke (discussed below). These discoveries led to extensive diamond drilling, and the cores are at present being studied from a scientific point of view (Nielsen et al. 2000). A detailed description of the Skaergaard deposit is given by Nielsen et al. (2005). It is known to be a world-class deposit containing 10 million ounces of gold and 30 million ounces of palladium (Platina Resources Limited: www.platinaresources.com.au), and exploration work including diamond drilling continues at the time of writing (2011). Both these metals are highly valued at the time of writing and unlikely to lose value in the near future.

The juxtaposition of gabbros (with multiply refilled magma chambers and a late ultramafic suite - see next section), intense dyke swarms and basaltic lavas is reminiscent of ophiolite complexes, except for the presence of continental rocks and lack of a mantle unit or pelagic sediments. The association represents the earliest stages of ocean-floor formation and to this extent may be regarded as a continental margin ophiolite (Bernstein $e t$ al. 1992).

A major problem with the gabbros is their mode of emplacement, classically known as the 'room problem'. In no case is this very clear, and as stated above the emplacement mechanism of the Skaergaard intrusion, the most studied of all, is still in dispute.

\section{Ultramafic plugs etc.}

In the area to the immediate north and east of Kærven, several plug-shaped ultramafic bodies occur. They have 

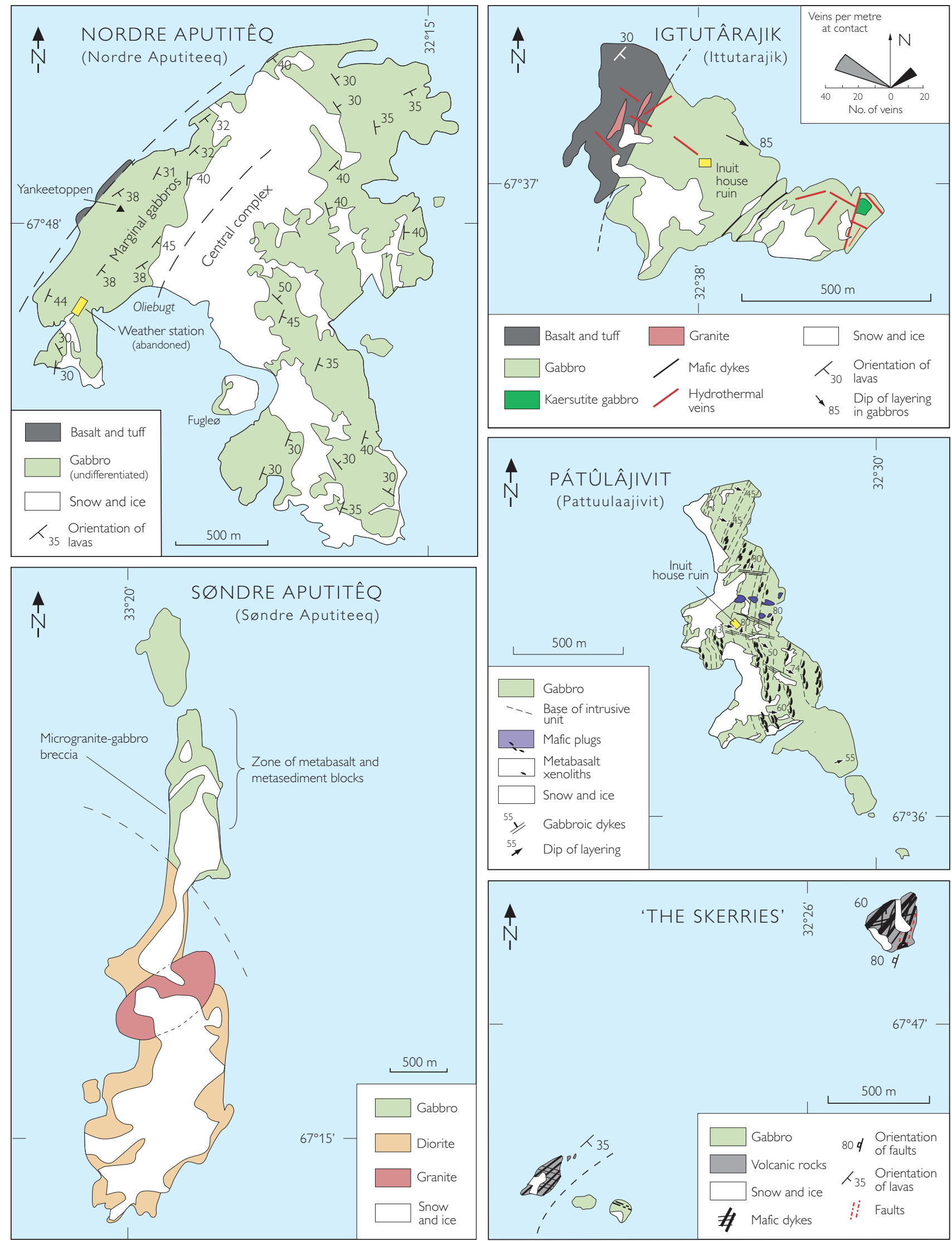

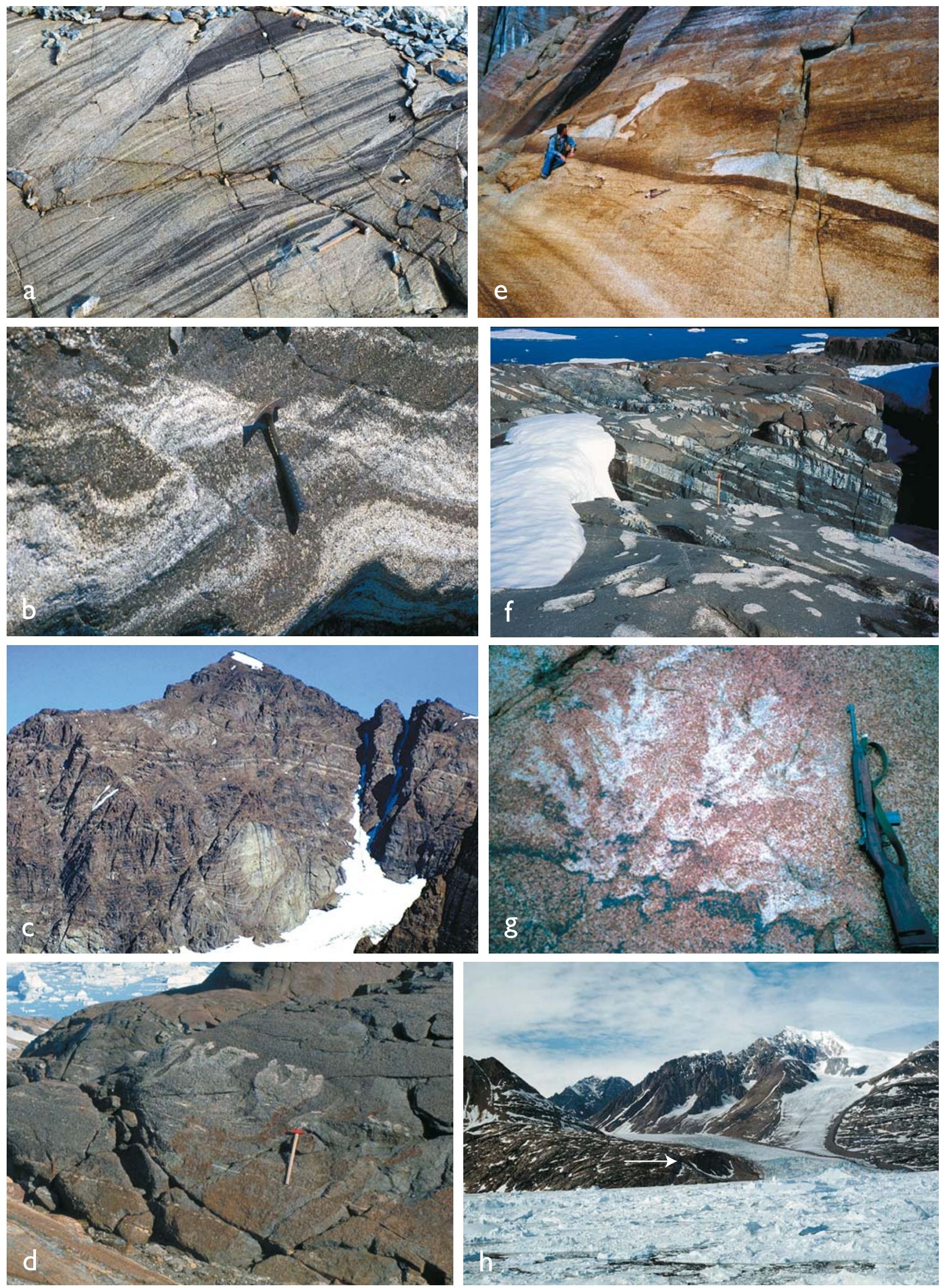
been studied by Prægel \& Holm (2001) and Holm \& Prægel (2006). In general, rock types from these intrusions include: dunite, wehrlite, lherzolite and olivine clinopyroxenite. The above-mentioned authors concluded they are cumulates from a magma of Icelandic type which was contaminated by local Archaean continental lithospheric mantle. Some intrusions are cut off by the Kærven and Kangerdlugssuaq intrusions, whereas others are clearly seen as plug-shaped, e.g. an almost circular body several hundred metres in diameter just south of the snout of the glacier that descends from Kangerlussuaq Tinde (Fig. 11h). It was called Mordor by Holm \& Prægel (2006), who reported that it is zoned with an ultramafic outer part and a gabbroic core.

A similar wehrlitic body was discovered just north of the contact of the Skaergaard intrusion at Watkins Fjord as a result of gravimetric studies of the Skaergaard intrusion (Blank \& Gettings 1973). It is poorly exposed, but by comparison with the ultramafic rocks on the western side of the fjord, it is interpreted as a plug. Indeed, the largely moraine-covered peninsula on which this body occurs is almost circular, suggesting that the wehrlite determines the shape of the peninsula. This body was mapped by McBirney (1997) as Precambrian, but it has Palaeogene isotopic characteristics (Stewart \& DePaolo 1990; S. Bernstein, personal communication 1995). As it may well be intersected by

\section{Facing page:}

Fig. 11. Magmatic structures in gabbros. a: Discordant layering on the island of Pattuulaajivit. b: Folded and disrupted layering in the Kap Edvard Holm Lower Layered Series. c: Face of 'Gabbrofjeld' (about $500 \mathrm{~m}$ high), Skaergaard intrusion, showing various layered features including macrorythmic layering (lower part of picture), draping a large autolith (lower centre) and the Triple Group (three-quarters up from the bottom of the picture). The latter is associated with precious metal mineralisation. d: Anorthositic diapirs intrusive into a wehrlite, Kap Edvard Holm Lower Layered Series. e: Anorthositic diapir in the Lower Zone of the Skaergaard intrusion. f: Anorthositic xenoliths/autoliths in the Kap Edvard Holm Middle Layered Series at Den Lave Pynt (Fig. 9a). g: Dendritic plagioclase lying in the plane of layering in the lowest unit of the upper zone (UZa) of the Skaergaard intrusion (Sonnenthal 1992). h: Ultramafic plug (arrow, 'Mordor' of Holm \& Prægel 2006) cutting the basement on the west side of Kangerlussuaq. The high, snow-capped peak in the background is Kangerlussuaq Tinde (c. $2200 \mathrm{~m})$. the Skaergaard intrusion at depth, it may be the source of the so-called gabbro picrite inclusions in the northern Marginal Border Series of the Skaergaard intrusion, which Wager \& Deer (1939) considered to be early cumulates rafted up from the Hidden Layered Series.

The first wehrlites from the Kap Edvard Holm complex were reported by Bernstein et al. $(1992,1996)$ and Tegner and Wilson (1993). They are known as the wehrlite suite, although not all are strictly wehrlites, but peridotites sensu lato. They are mica-bearing and both intrude and replace the gabbros; Fig. 11d shows anorthosite diapirs emplaced into a wehrlite. These rocks are strongly reminiscent of ultramafic rocks in ophiolite complexes (Juteau et al. 1988).

Since the initial discoveries, ultramafic components have been reported from many layered gabbros in East Greenland (Brandriss et al. 1995, 1996; Brandriss \& Bird 1999; Bernstein \& Bird 2000). It has been suggested that such ultramafic magmas form by suppression of plagioclase crystallisation caused by the release of volatiles from hydrothermally altered basaltic xenoliths, a process documented in some detail in the newly discovered Noe-Nygaard intrusion (Bernstein \& Bird 2000). Interestingly, the Skaergaard intrusion lacks this suite of rocks, possibly because it does not have a large volume of basaltic xenoliths (Irvine et al. 1998).

A remarkable dyke in the Astrophyllite Bay complex at Astrofyllit Bugt in Amdrup Fjord (Fig. 12) is crowded with angular, ultramafic xenoliths (Brooks \& Nielsen 1982a). It cuts a large gneiss inclusion and other field relations cannot be determined, except that it is older than the syenite (and younger than the gneiss). It yields a K-Ar age of $c .52 \mathrm{Ma}$, but the isotopic systematics may have been reset by the intrusion of the syenite.

Ultramafic inclusions (largely harzburgites) in dykes at Wiedemann Fjord will be discussed in the subsequent section on dykes and sills.

\section{Felsic intrusions and volcanic rocks}

An important characteristic of the East Greenland rifted margin is the large amount of felsic intrusive rocks of broadly syenitic character (Figs 12,13). The distribution of syenites in the Kangerlussuaq area is shown in Fig. 12, in the Mesters Vig area in Fig. 14 and in the Kialeeq (Kialineq) area in Fig. 16. Figures 13, 15 and 17 depict the occurrence and textures of the syenites in these three areas. Felsic, volcanic rocks are almost 


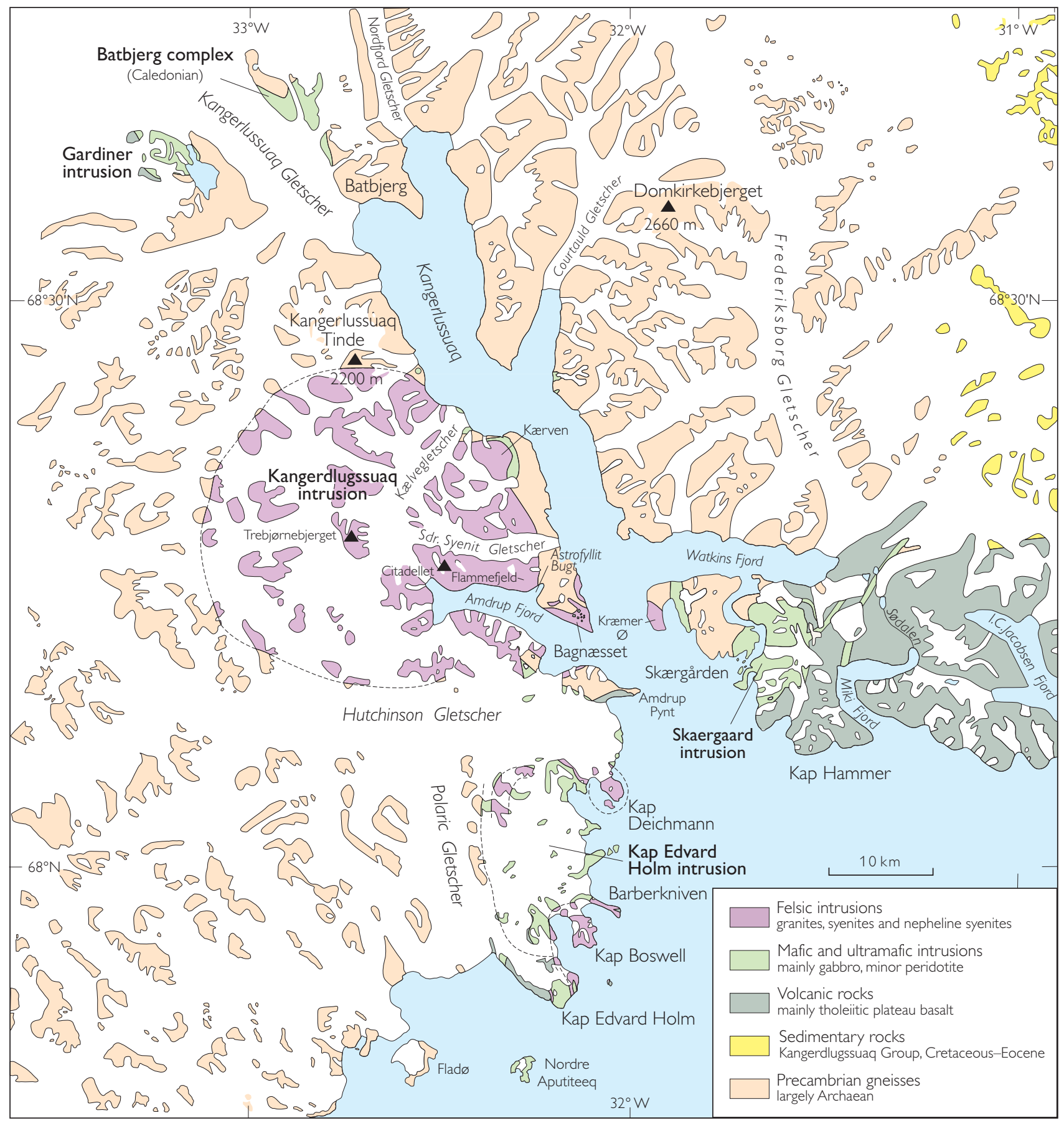

Fig. 12. Geological map of the Kangerlussuaq area (based on publications of L.R. Wager and the author's observations). Location shown in Fig. 2.

unknown except for a small outcrop in Kialeeq (Brown $\&$ Becker 1986) and various porphyries infilling the calderas of Kap Parry and Kap Simpson (Figs 14a, 15b; Schaub 1938, 1942). In the Kangerlussuaq area, Brooks
\& Nielsen (1982a) showed that, at the present level of exposure, syenite occupies approximately twice the area of gabbro. 


\section{The Kangerlussuaq - Blosseville Kyst area}

The largest of the East Greenland syenites is the Kangerdlugssuaq alkaline intrusion (its name is the old spelling of the fjord Kangerlussuaq) and its satellites (Figs $12,13 \mathrm{a}, \mathrm{b}, \mathrm{c}$ ), covering $>800 \mathrm{~km}^{2}$, making it among the largest syenitic bodies in the world. It has been described in detail by Wager (1965), Kempe et al. (1970) and Kempe \& Deer $(1970,1976)$, and its satellite intrusions by Deer \& Kempe (1976). Broadly, it zones from oversaturated, almost granitic rocks ('nordmarkites', Fig. 13c) adjacent to the country gneisses over syenites (known as pulaskites in the literature) to strongly undersaturated nepheline-sodalite syenites ('foyaites', Fig. 13b) at the core. These plutonic rocks are usually spectacular and massive, with very few joints. Some are strongly laminated, others have eye-catching dark, perthite phenocrysts several centimetres across ( - feldspars were studied in some detail by Kempe 1966). Brooks \& Gill (1982) reported additional information on the mineralogy of the intrusion and favoured the idea that the most primitive magma was represented by the undersaturated core (a reversal of all previous thinking), and that these magmas had reacted with granitic country rock leading to the quartz-oversaturated peripheral rocks; a scenario consistent with the available isotopic information (Pankhurst et al. 1976). Other workers (Wager 1965; Kempe et al. 1970) have considered the progression of rocks to be the reverse and the main agent to have been crystal fractionation. However, they were not able to explain the mechanism by which the thermal barrier in the residual system (quartz-nepheline-kalsilite) has been crossed. Riishuus et al. $(2006,2008)$ reported new geochemical and isotopic data from the Kangerdlugssuaq intrusion with determinations of major elements, supplied a comprehensive list of trace elements and $\mathrm{Sr}-\mathrm{Nd}-\mathrm{Hf}-\mathrm{Pb}$ isotopes, using a new sample collection. They essentially agreed with the earlier model of Brooks \& Gill (1982) in that differentiates of mantle-derived basic magmas had reacted with the gneissic basement in deep mantle chambers, where periodic injections into the main chamber became progressively less contaminated. Riishuus et al. (2005) also reported on the nearby Astrophyllite Bay complex where basic pillows were previously claimed by Nielsen \& Brooks (1981) to have caused melting of the gneiss, and diffusive reactions had formed the enclosing syenite. The new study shows this not to be so: the syenite and the basaltic pillows likely were comagmatic, albeit with different degrees of contamination.
Interestingly, an outcrop of nepheline syenite has been found in the southern slopes of Flammefjeld (Fig. 12), where the map shows quartz syenite of the Snout Series (author, unpublished observation). Unfortunately this has never been followed up and its extent and relationships are unknown.

The Kangerdlugssuaq intrusion hosts many pegmatites, some merely coarse-grained equivalents of the main rock types, others agpaitic with minerals such as arfvedsonite, aegirine, astrophyllite, låvenite, catapleite and hjortdahlite. Johnsen et al. (1998) described the mineral kentbrooksite from such a pegmatite, previously thought to be eudialite/eucolite (Kempe \& Deer 1970). This is a Mn rare-earth element - Nb-F endmember of the eudialyte group. Kupletskite, the Mn analogue of astrophyllite, also occurs (Christiansen et al. 1998), and the East Greenland syenites seem to be unusually Mn-rich (e.g. Werner Bjerge, where kupletskite has also been documented by Brooks et al. 1982). Another interesting mineral from these syenites is normandite (a Mn-rich member of the cuspidine group), described by Perchiazzi et al. (2000). A nepheline syenite pegmatite cutting nearby Bagnæsset also contains astrophyllite (Layne et al. 1982), an undetermined member of the eudialyte group, kupletskite and narsarsukite (C.K. Brooks, unpublished data). Astrophyllite also occurs on Kræmer $\varnothing$ (see below).

Other syenites in the Kangerlussuaq area (Fig. 12) are much smaller in size and are all quartz-bearing. These include the Kap Boswell syenite and associated intrusions, the Kap Deichman syenite and associated bodies along Hutchinson Gletscher (Fig. 13d; Deer et al. 1984), the Kræmer $\varnothing$ syenite (Fig. 13e; Brooks 1991a), the satellites of the Kangerdlugssuaq intrusion (Deer \& Kempe 1976), including the Kærven syenites (Holm 1991; Holm \& Prægel 1988; Nielsen 1989; Holm et al. 1991) and bodies intruding the main Kangerdlugssuaq intrusion. The Bagnæsset quartz syenite may also be a satellite but was considered by Deer \& Kempe (1976) to be earlier. Many of these rocks have a peralkaline tendency (e.g. have late alkali pyriboles), others are thoroughly peralkaline with alkaline pyroxenes and amphiboles and minerals such as astrophyllite (Layne et al. 1982) and aenigmatite (this most notably in the syenite of Barberkniven in the Kap Boswell complex, Fig. 12). Characteristic accessory minerals of these syenites are chevkinite and zircon. An almost aphyric, peralkaline vein cutting the Kap Boswell syenite, showing turbulence structures is shown in Fig. 13f. A pegmatite belonging to the Kræmer $\varnothing$ syenite contains large 

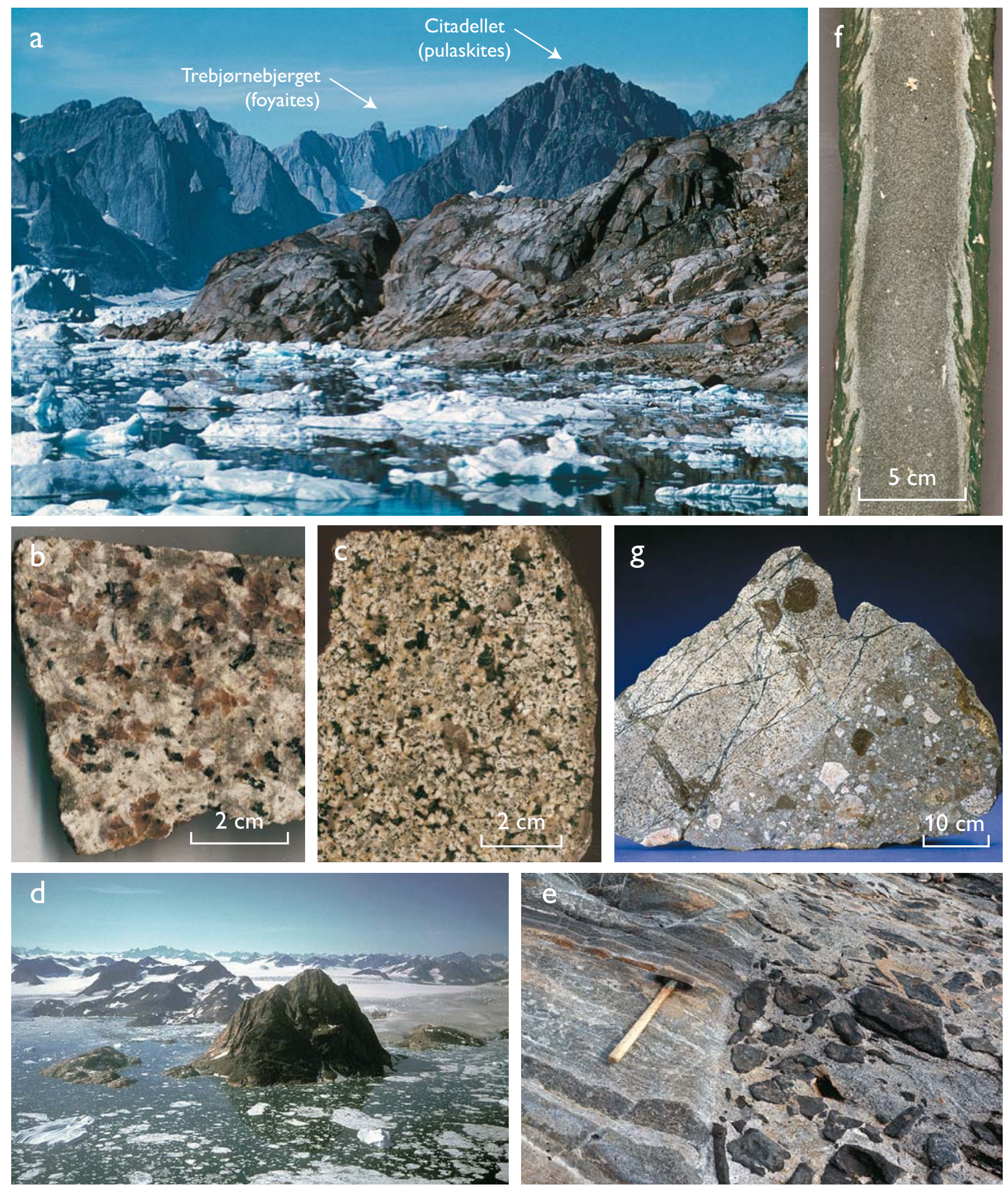

Fig. 13. Syenites at Kangerlussuaq. a: View from Bagnæsset into Amdrup Fjord. The Bagnæsset syenite, a satellite of Kangerdlugssuaq intrusion, forms the foreground. Trebjørnebjerget, c. $20 \mathrm{~km}$ distant, is at the centre of the Kangerdlugssuaq alkaline intrusion (Fig. 12). b: Slab of Kangerdlugssuaq foyaite. Pinkish crystals: nepheline; off-white crystals: alkali feldspar; dark crystals: pyroxene and garnet. $c$ : Kangerdlugssuaq nordmarkite with 10-20\% quartz (grey), sodic amphibole (black) and abundant miarolitic cavities. d: The Kap Deichman syenite intruding layered gabbros of the Kap Edvard Holm complex (for location see Fig. 9a). View from $c .1500 \mathrm{~m}$ altitude, looking west. e: Contact of the Kræmer $\varnothing$ syenite with Archaean gneiss (left), showing part of the $10 \mathrm{~m}$ wide contact facies of breccia (right). $\mathbf{f}$ : Almost aphyric, peralkaline vein cutting the Kap Boswell syenite, showing turbulence structures caused by the intrusion of two magmas with contrasting composition and viscosity. Green colour caused by high aegirine content. g: Breccia from the Flammefjeld complex. Large clast in the left seamed with molybdenite-filled fractures. 
crystals of astrophyllite (Layne et al. 1982), strongly sodic pyroxenes and amphiboles and a zone very rich in zircon and quartz. Comendititic dykes which cut the Skaergaard gabbros are thought to be late products of the Kræmer $\varnothing$ syenite (Brooks \& Rucklidge 1976). A massive biotite granite crops out on the south side of Amdrup Fjord. It has very widely spaced jointing and almost no dykes, so is clearly young. The Flammefjeld complex will be referred to below.

The felsic plutons generally contain few dykes and have widely spaced joint systems, which leads to massive walls and towers (Fig. 13a). If the area were not so remote some of these rocks might produce handsome dimension stones: although sometimes blindingly white in outcrop (Fig. 15a), the colour on freshly blasted surfaces is blue, resembling the well-known larvikite. Occasionally, they may be crumbly, giving more rounded outcrops and areas of gravel. Borgtinderne (Fig. 2) is a major, largely syenitic body, as seen in Fig. 6a invading the lower part of the cliffs in the Main Basalts (Brown et al. 1978).

Along Blosseville Kyst, small felsic bodies are found in the Ryberg Fjord area and in the mountains to the east where syenite sills are quite common, although not studied in detail. They have yielded a $\mathrm{U} / \mathrm{Pb}$ zircon age of $50.2 \pm 1.1 \mathrm{Ma}, \mathrm{a}^{40} \mathrm{Ar} /{ }^{39} \mathrm{Ar}$ biotite age of $51.6 \pm 0.04$ $\mathrm{Ma}$, and a ${ }^{40} \mathrm{Ar} /{ }^{39} \mathrm{Ar}$ amphibole age of $54 \pm 0.4 \mathrm{Ma}$ (P. Japsen, personal communication 2011). The zircon and biotite ages are close to combined ages from a number of methods for the Kangerdlugssuaq intrusion (see below), while the older amphibole age may be due to excess argon. In the I.C. Jacobsen Fjord area, syenite blocks found in the beach alluvium are thought to have been transported by glaciers and icebergs from the Borgtinderne intrusion, which they closely resemble (Brooks 1991b). Small granitic and syenitic bodies also occur in the above-mentioned, largely mafic-ultramafic Lilloise intrusion (Brown 1973; Chambers \& Brown 1995).

A notable feature of almost all these intrusions is the presence of basaltic material. Many contain angular xenoliths of basalt showing the former extent of lavas, even when no overlying basalt is present today. Examples include the basaltic xenoliths in the Kangerdlugssuaq intrusion, remarked on by all the authors cited above, and numerous large xenoliths in the Kræmer $\varnothing$ syenite (Brooks 1991a). Others contain basaltic pillows and pillowed dykes, where ovoid basaltic bodies show crenulate, chilled margins to the enveloping syenite (Fig. 17c). These are unequivocal evidence that mafic and felsic magmas were concurrently present. Examples include well-developed pillows at Astrofyllit Bugt (Nielsen \& Brooks 1991), studied in detail by Riishuus et al. (2006), hybridising basaltic material at Nuuk, Kialeeq described by Brooks (1977), shown in Fig. 17c, and generally throughout the Kialeeq district as described by Brown \& Becker (1986), who mapped large areas as 'net-veined complexes'. The latter name encompasses both pillowed bodies and others where inclusions are angular, although there is a complete transition between the two. Also at Borgtinderne (Fig. 2), basaltic xenoliths and hybridising basaltic material were described by Brown et al. (1978). A fine netveined/pillowed complex is found on the northern side of Hutchinson Gletscher (Fig. 12) on the west side of Kangerlussuaq, which may be part of the Kap Edvard Holm complex (C.K. Brooks, unpublished data).

Flammefjeld (Geyti \& Thomassen 1984) is a unique locality in the Kangerlussuaq area, although it closely resembles Malmbjerg in the Mesters Vig area, to be described below. The top of the mountain is hydrothermally altered to brilliant red and yellow gossans (hence the name meaning Flame Mountain). Although not exhaustively investigated, it consists of late-stage intrusive phases, aplite, quartz-feldspar porphyries, breccia pipes and dykes within the Kangerdlugssuaq syenites. A breccia pipe contains numerous clasts, some of which display a stockwork of fractures containing fine-grained molybdenite (Fig. 13g), a classical texture of porphyry molybdenum deposits. Drilling, the only way to determine the depth and extent of this deposit, has not yet been carried out. A number of base and precious metal veins cut the surrounding rocks, notably the 'Yellow Zone' with tetrahedrite-bearing veins having elevated levels of copper, zinc, lead, silver and gold (Thomassen \& Krebs 2001). Interestingly, both the Flammefjeld and Malmbjerg occurrences show a close resemblance to the Climax-type molybdenum deposits of the western United States, although the geological setting seems to be quite different.

In addition to age data from the Ryberg Fjord area, reported above, several attempts to date the felsic intrusions have been made in the past (Beckinsale et al. 1970; Gleadow \& Brooks 1979; Noble et al. 1988), but much of this earlier work is unreliable. As previously noted, K-Ar dating was useful at the time, but it is not sufficiently precise to answer contemporary questions. Tegner et al. (2008) reported high-precision ${ }^{40} \mathrm{Ar} /{ }^{39} \mathrm{Ar}$ results, showing that the oldest felsic rock is an alkali granite of Kærven at $52.8 \pm 1.3 \mathrm{Ma}$, which cuts the 

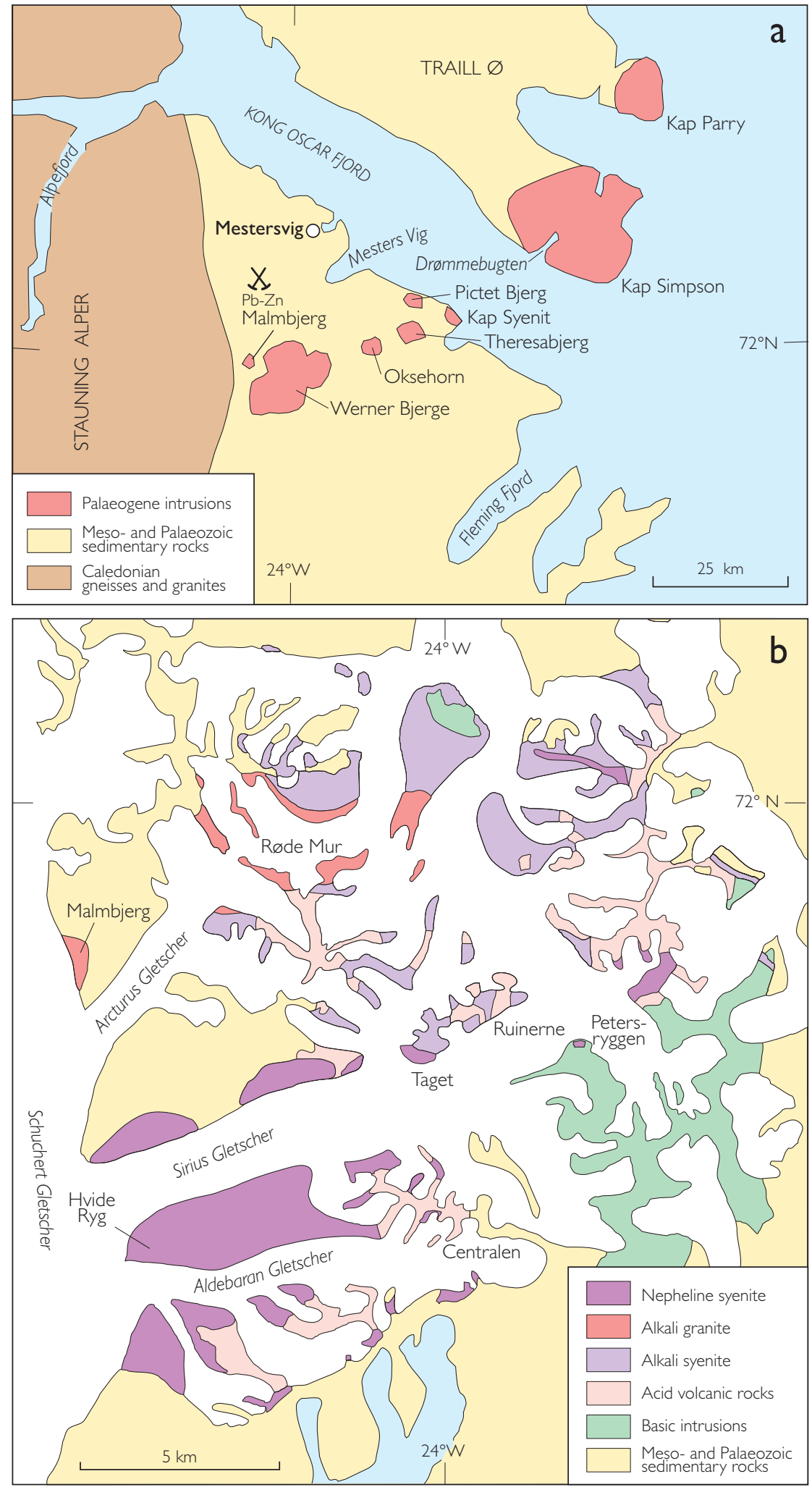

Fig. 14. a: The Mesters Vig area showing three large subvolcanic complexes and five smaller ones forming a rough line oblique to the continental margin. These complexes contain large amounts of syenite and granite and Werner Bjerge also nepheline syenite. Gabbro and diorite occur at Theresabjerg, Oksehorn and Werner Bjerge. b: Map of the Werner Bjerge complex (from Bearth 1959). Location shown in Fig. 2. 
Kærven gabbro (Ohja 1966), itself dated at $55.1 \pm 1.4$ Ma. The Kangerdlugssuaq biotite granite, which crops out on the south side of Amdrup Fjord is considered, based on field relations, to be the youngest major intrusion in the area, has an age of $46.6 \pm 0.9 \mathrm{Ma}$ (Tegner et al. 2008). It was thought to be contemporaneous with the nearby porphyry molybdenum deposit at Flammefjeld (Geyti \& Thomassen 1984), but a Re-Os age on molybdenite of $39.6 \pm 0.1 \mathrm{Ma}$ from Flammefjeld was reported by Brooks et al. (2004), showing it to be substantially younger. Some alkaline basic dykes on the northern side of Amdrup Fjord, which contain xenoliths and megacrysts, are even younger: $c .34 \mathrm{Ma}$ (Gleadow \& Brooks 1979).

Of particular interest is the summary of radiometric dates for the Kangerdlugssuaq intrusion by Tegner et al. (2008, fig. 3), which shows a constant age of $c$. $50 \mathrm{Ma}$ using a variety of methods (mineral and whole rock $\mathrm{Rb}-\mathrm{Sr}$, biotite $\mathrm{K}-\mathrm{Ar}$, biotite ${ }^{40} \mathrm{Ar} /{ }^{39} \mathrm{Ar}$, fission-track zircon and titanite) but a reduced age of $c .36 \mathrm{Ma}$ for fission-track apatite. This clearly shows that the intrusion rapidly cooled to a temperature estimated at $c$. $210^{\circ} \mathrm{C}$ and then more slowly to the closure temperature of apatite $\left(c .120^{\circ} \mathrm{C}\right)$. The study convincingly suggests that, in general, the ages obtained are ages of intrusion preserved by rapid cooling.

\section{The Mesters Vig area}

A further cluster of felsic rocks occurs north of Scoresby Sund (Fig. 14a). No depth estimate exists for these intrusions, but it is generally agreed that they are very shallow, and they are regarded as subvolcanic. Of these, the Werner Bjerge complex shown in Fig. 14b is by far the largest and best studied (Bearth 1959: general geology; Brooks et al. 1982: mineral chemistry). Here, a full spectrum of oversaturated, saturated and undersaturated types occurs, along with gabbros. The intrusions at Kap Parry and Kap Simpson (Tyrrell 1932; Schaub 1942) are caldera complexes with lavas (largely felsic porphyries interpreted as caldera fill, Fig. 15b), but hydrothermal alteration is widespread (Fig. 15c) and masks the rocks. Some of the alteration haloes could mark blind ore deposits awaiting discovery.

Syenites and alkali granites and dyke swarms with a wide range of compositions (lamprophyres, trachytes and comendites, often with spectacular spherulitic textures) are also present. Other smaller bodies of the area have been described by Kapp (1960). Their locations are shown in Fig. 14a. Of particular importance in this area is Malmbjerg, originally known as 'Erzberg' by the Swiss and Austrian geologists who discovered it. This is a small stock of perthitic granite with porphyritic aplite and granite intruding Palaeozoic sedimentary rocks just west of the main Werner Bjerge complex that hosts the Malmbjerg porphyry molybdenum deposit (Figs 14a, b; Kirchner 1964; Harpøth et al. 1986; Schønwandt 1988). The mountain is depicted in Fig. 15d. With c. $150 \mathrm{Mt}$ of $0.23 \% \mathrm{MoS}_{2}$, Malmbjerg is among the world's largest molybdenum deposits and promises to be of exploitable value. However, access is difficult. The molybdenum deposit, a stockwork of quartz veins containing molybdenite, wolframite, topaz, fluorite, etc., forms an inverted bowl-like structure centred on the quartz porphyry.

Like the syenites at Kangerlussuaq, those of Werner Bjerge have yielded a rich assortment of rare minerals (Brooks et al. 1982): kupletskite, narsarsukite, pyrochlore, chevkinite, Mn-pectolite, a Li-bearing magnesioarfvedsonite, unindentified zirconosilicates possibly including hjortdahlite, as well as rosenbuschite. A new mineral, named kochite, which is a member of the rosenbuschite group, was described by Christiansen $e t$ al. (2003). It occurs along with nepheline and alkali feldspar.

K-Ar and fission-track dating has been carried out of the Mesters Vig rocks over the years (Beckinsale et al. 1970; Rex et al. 1979; Gleadow \& Brooks 1979). Recent ${ }^{40} \mathrm{Ar} /{ }^{39} \mathrm{Ar}$ dating (C.K. Brooks, C. Tegner and R.A. Duncan, unpublished data 2004) shows a spread of ages from $41.6 \pm 0.5 \mathrm{Ma}$ for a syenite from Kap Parry to $26.9 \pm 0.6 \mathrm{Ma}$ for the Werner Bjerge alkali granite and $25.5 \pm 0.4 \mathrm{Ma}$ for the Malmbjerg granite. These young ages reaching into the Late Oligocene were unexpected, but have been confirmed by a Re-Os age on molybdenite from Malmbjerg of $25.8 \pm 0.1 \mathrm{Ma}$ (Brooks et al. 2004). This age distribution is obscure in the plate-tectonic context, although there seems to have been an acceleration in spreading rate at $c .30 \mathrm{Ma}$ (Mosar et al. 2002b) and spreading on the Ægir Ridge eventually ceased at c. $25 \mathrm{Ma}$. However, it is not obvious what relevance, if any, these correlations might have.

Geochronological data reported by Price et al. (1992) on tholeiitic sills of the area indicate that they date back to $c .54 \mathrm{Ma}$, giving a span of magmatic activity of nearly $30 \mathrm{Ma}$, during which existing radiometric data do not suggest any clear gap, unless possibly in 

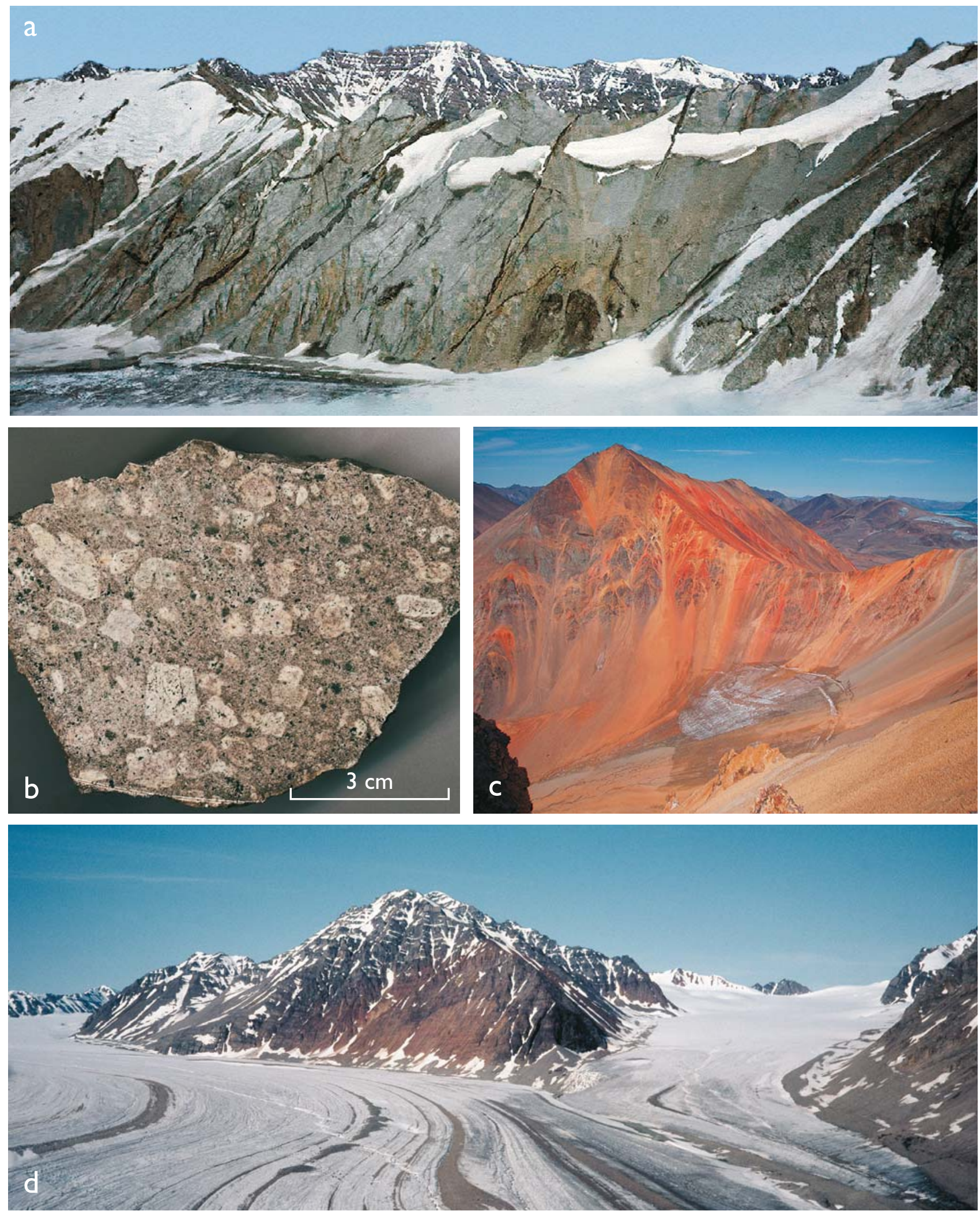

Fig. 15. a: Foyaites (nepheline syenites) on the north side of Aldebaran Gletscher, Werner Bjerge. Note sparse dykes, very little jointing, both indicative of young age, and Mesozoic sedimentary rocks in mountain behind. The rocks have a very low content of ferromagnesian minerals and are very light coloured. b: Typical feldspar-porphyritic trachyte such as makes up the caldera fill at Kap Simpson and Kap Parry (along with volcaniclastic deposits). c: Extensive hydrothermal alteration in the caldera complex of Kap Simpson (from Thomassen \& Nielsen 2006). d: Malmbjerg seen from the Schuchert Gletscher with Arcturus Gletscher on the right. The granite cupola is deep red due to hydrothermal alteration that also extends out into the sedimentary host rocks (from Thomassen \& Nielsen 2006). 
Fig. 16. Geological map of the Kialeeq area (known as Kialineq in the geological literature). Intensity of dyking broadly indicated. Geological localities shown in red, with corresponding geographical names in black (modern orthography). Field of view of Fig. 17a also shown. Redrawn from Bernstein \& Bird (2000) with additional observations by the author. Location shown in Fig. 2.

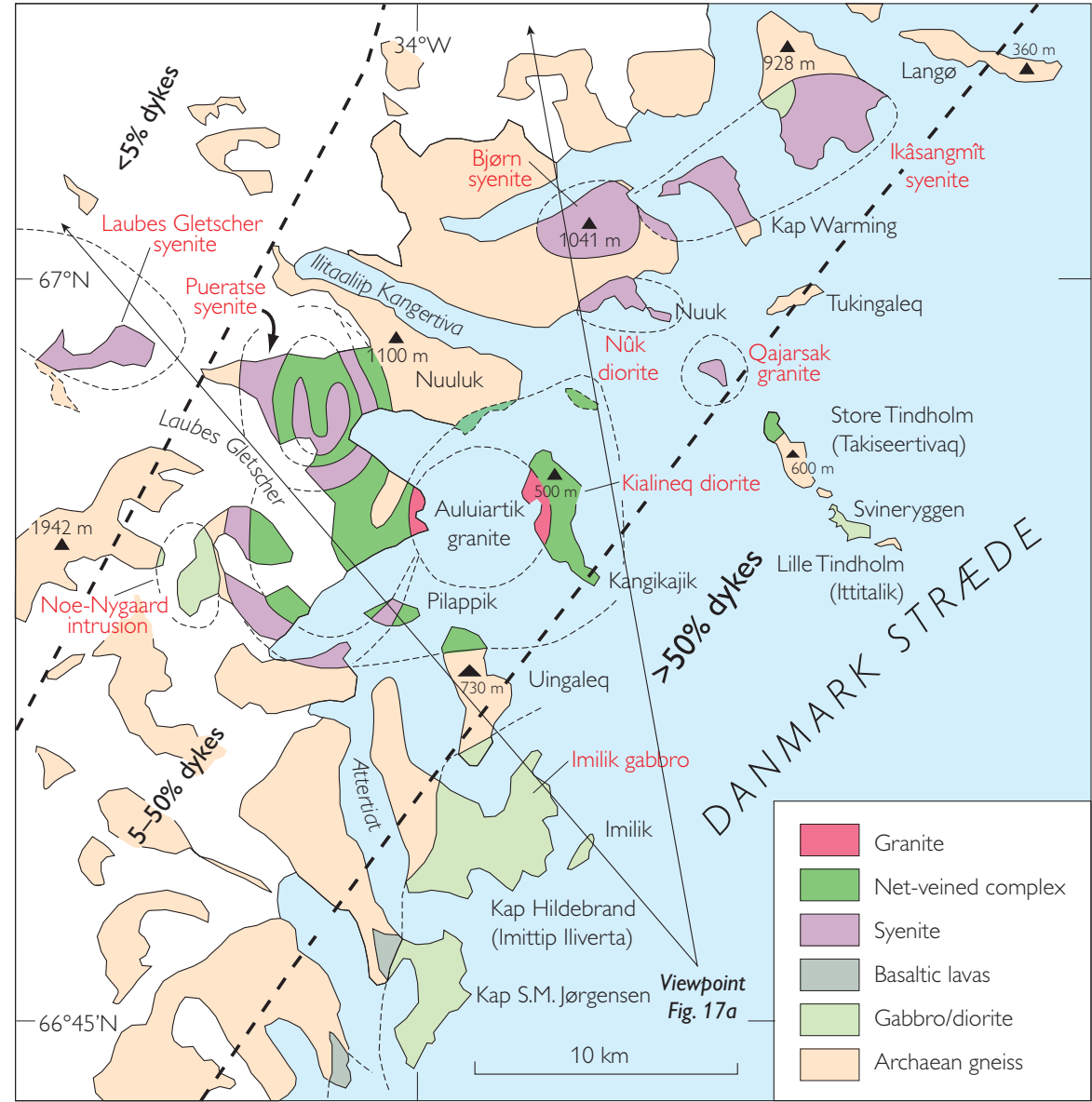

the period 54-41 Ma. It has been suggested by several authors that late activity in this area was linked to the splitting off of the Jan Mayen microcontinent from Greenland by the northwards propagation of the Kolbeinsey Ridge (e.g. Nunns 1983a, b), although, again, any link is very tenuous.

The intrusions in this area apparently connect with an aeromagnetic anomaly offshore, which also appears on the conjugate Vøring margin and was called the Traill $\varnothing$ - Vøring Igneous Complex by Olesen et al. (2007). The Mesters Vig intrusions have also been linked by Nielsen (1987) and Larsen, H.C. (1988) to an abortive attempt to split off a continental fragment along a lineament roughly from inner Kangerlussuaq to the Werner Bjerge area, as actually happened later, during the further rift jump with the Jan Mayen Plateau. See also Larsen, L.M. \& Watt 1985, although this work largely deals with the succession of basalt formations rather than the activity at Mesters Vig. As an alternative, could these intrusions follow the outer pseudo-fault (Hey et al. 1989), which formed during the northwards propagation of the Kolbeinsey Ridge?

\section{The Kialeeq (Kialineq) - Kap Gustav Holm area}

South of Kangerlussuaq, felsic rocks are abundant in the Kialeeq - Kap Gustav Holm area (Brown \& Becker 1986; Brown et al. 1977; Myers et al. 1993). The distribution of those in the Kialeeq area (informally known as Kialineq in the geological literature) is shown in Fig. 16. Much field work was carried out by the Geological Survey of Greenland in the 1970s, but the results remain unpublished in the case of Kialeeq. Brooks (1977) described a striking example of hybridisation in the extensive net-veined unit. The intrusions at Kialeeq include both syenites and granites, with extensive areas of acid-basic, net-veined complexes and the large Imilik gabbro discussed previously. The area is poorly 

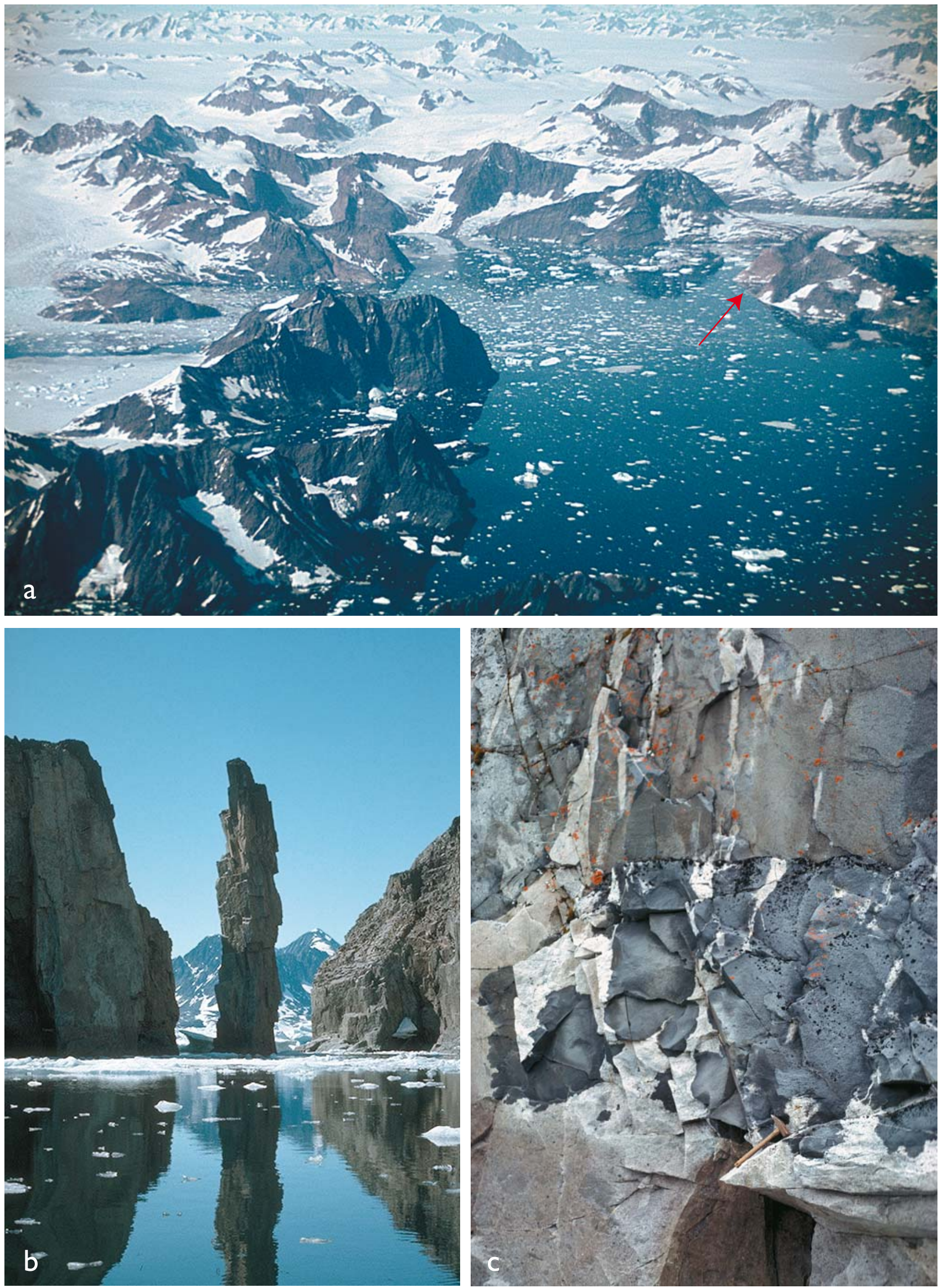
known due to the extremely rugged nature of the landscape, with its extensive ice-cover, jagged mountains and coasts which almost everywhere rise steeply from the sea (Figs 17a, b).

Radiometric ages have been reported by Beckinsale et al. (1970), Brown et al. (1977) and Gleadow \& Brooks (1979), while a number of mineral and wholerock $\mathrm{Rb}-\mathrm{Sr}$ isochrons, $\mathrm{K}-\mathrm{Ar}$ and ${ }^{40} \mathrm{Ar} /{ }^{39} \mathrm{Ar}$ dates have been determined by D.C. Rex but remain unpublished. The two most recent are ${ }^{40} \mathrm{Ar} /{ }^{39} \mathrm{Ar}$ dates of $36.2 \pm 0.6$ Ma from the Nûk diorite (the rock studied by Brooks 1977) and 37.2 \pm 2.9 Ma from the Ikâsangmît syenite, both in the northern part of the area. Previous dating suggests that intrusions in the southern part of the area are $c .2$ Ma younger (D.C. Rex, personal communication 1998), but this suggested bimodality of ages remains to be tested. The reason for these young ages remains conjectural as the only major plate-tectonic event at this time was the cessation of spreading in the Labrador Sea (Srivastava \& Tapscott 1986; Roest \& Srivastava 1989) and a change from right-lateral shear to oblique divergence along the Lena Trough (Engen et al. 2008). Again, if there is any connection, it is not obvious.

Until the discovery of the Sulugssut complex (see below under nephelinites), the Kap Gustav Holm area was the most southerly known Palaeogene intrusive centre in East Greenland. Only Palaeogene sedimentary rocks and basalts were originally reported by Wager (1934), but Myers et al. (1993) described a number of generally circular intrusive bodies beginning with gabbro, which was tilted by the coastal flexure, followed by bodies of monzonite, syenite and granite, which are unaffected by the flexure. The granites gave a $\mathrm{Rb}-\mathrm{Sr}$ isochron age of $53 \pm 5 \mathrm{Ma}$ and a monzonite and the granite gave whole rock and biotite $\mathrm{Rb}-\mathrm{Sr}$ ages of $50 \pm 3 \mathrm{Ma}$ in both cases. K-Ar ages of 51-49 Ma were obtained for biotites

\section{Facing page:}

Fig. 17. Geological features in the Kialeeq area (known as Kialineq in the geological literature). a: Oblique air view of central Kialineq: Auluiartik granite at right centre (red arrow), northern part of Imilik gabbro at bottom left. Field of view shown in Fig. 16. b: Coast at the Tindholm islands, showing the abrupt topography of the area and the difficulty of field work. c: Basic pillows in syenite at Nuuk where hybridisation in vertical pipes generates a diorite at the top of the picture (see Brooks 1977), with hammer for scale. and hornblende from these rocks. The complex is thus quite independent of the nearby Kialeeq intrusions.

\section{Syenite genesis}

In the Hebrides and Northern Ireland on the other side of the rift zone, the predominant felsic rock type is granitic, found at most of the intrusive centres (e.g. Emeleus 1955, Walsh et al. 1979, Meighan \& Gamble (1972). Syenite only occurs in minor amounts (e.g. Hole \& Morrison 1992). Large amounts of felsic volcanic rocks have been reported from the volcanic successions of several other rifted volcanic margins (e.g. Etendeka-Paraná: Peate, D.W. 1997; Lebombo-Nuanetsi: Cox 1988; Yemen-Ethiopia: Menzies et al. 2001). The felsic rocks in these cases are largely oversaturated rhyolites and/or granites, although some large igneous provinces, such as the Siberian Traps (Zolotukin \& Al'mukhamedov 1988), Columbia River (Hooper 1997) and Rajmahal (Kent et al. 1997) seem to be relatively free of evolved rocks. Phonolites do occur (e.g. Marsh 2010, probably part of the Etendeka province), but are not voluminous.

Perhaps the East Greenland magmas with their largely syenitic compositions were less explosive than their rhyolitic counterparts in other provinces such that venting to the surface environment was minor. We do see, however, the classic distribution where volcanic rocks are largely basaltic and plutonic rocks are predominantly felsic, and there is a clear gap in $\mathrm{SiO}_{2}$ contents (the 'Daly Gap').

Possibly felsic lavas were once more abundant in East Greenland and have since been removed by erosion as was suggested by Hunter \& Sparks (1987) to explain the low amounts of granophyre within the Skaergaard intrusion. The conclusions of this paper were refuted by Brooks \& Nielsen (1990), McBirney \& Naslund (1990) and Morse (1990), who among other arguments pointed out that no rhyolites are found in the lava pile. This makes the suggestion by Hunter \& Sparks (1987) unlikely.

Erratic blocks of rhyolitic ignimbrite have been reported from the island of Nordre Aputiteeq (Brooks $\&$ Nielsen 1982a). Their source is unknown, although they are likely related to nephelinitic parents such as the Gardiner complex (the source of the numerous boulders of phonolitic tinguaites, probably deriving from dykes, found on raised beaches around the Skaergaard 
intrusion has likewise never been located; see Brooks \& Rucklidge 1974).

The origin of the East Greenland felsic rocks remains conjectural. They were intruded over a much extended period (right down to $c .25 \mathrm{Ma}$ ), which seems to rule out the possibility of derivation from the voluminous basaltic magmas whose extrusion was largely complete $>20$ Ma before this. However, it must be borne in mind that basaltic magmas were available throughout the period of magmatism (albeit subsequently in small amounts), so this argument may be fallacious.

Two other possibilities have been entertained. Firstly, that the syenites were produced by interaction of later basic magmas and their differentiates with country rock, as suggested above for the Kangerdlugssuaq intrusion (Riishuus et al. 2008), or secondly that underplated gabbroic material, produced during the main period of basaltic activity and imaged seismically (Holbrook et al. 2001), became unstable, delaminated and was partially melted as it sank into the mantle to produce low-density syenitic magmas, which in turn invaded the upper crust. At present there are insufficient data, especially isotopic, to decide between these possibilities. As described above, recent information about the Kangerdlugssuaq intrusion (Riishuus et al. 2008) was interpreted as showing that it originated from a crustally contaminated, layered magma chamber at depth, followed by emplacement of the felsic magmas from the top of the chamber to their present position in the upper crust.

In summary, problems related to the syenites include their large volumes, their young age (later than continental separation), the prolonged period of activity, the association of quartz-oversaturated with undersaturated types (perhaps now resolved by the work of Brooks \& Gill 1985 and Riishuus et al. 2008) and the tendency for many intrusions to be peralkaline, which seems at variance with the general aluminous nature of the continental crust and may be a serious problem for models with substantial crustal involvement in their genesis. Furthermore, the genesis of two major porphyry molybdenum deposits remains obscure although they may be related to underlying amphibole-rich intrusions derived from mildly potassic, water-rich magmas which differentiated to silicic end products (the rhyolites and quartz porphyries at Flammefjeld and Mesters Vig).

\section{Nephelinites, carbonatites etc.}

Due to their small volumes and often inaccessible locations such as in inland areas bordering the ice sheet, these rocks have hitherto been poorly documented, although a good deal of unpublished work exists, including a study by the author and Stefan Bernstein of the Sulugssut complex. This probably explains why Saunders et al. (1997) do not refer to them at all in an otherwise comprehensive review of the North Atlantic Igneous Province. Nevertheless, their presence is clearly significant, showing the products of low degrees of partial melting, perhaps under a thick lithospheric lid.

The Gardiner complex at the head of Kangerlussuaq (Figs 2, 18a) is the most impressive representative. It is the best described of this suite of rocks, having been documented in a number of papers by Nielsen (1979, 1980, 1981, 1994), Nielsen \& Buchardt (1985), Nielsen \& Holm (1993) and Nielsen et al. (1997). This ring complex is $c .5 \mathrm{~km}$ in diameter and consists of ultramafic cumulates cut by a later generation of melilitolites (Fig. 18b) and carbonatites. It may be one of the most instructive occurrences of plutonic melilite-bearing rocks worldwide as exposure is excellent, although field work is offset by the frequent ferocious winds off the ice sheet. A study of the associated dyke rocks established the differentiation scheme for the parental melanephe-

\section{Facing page:}

Fig. 18. Nephelinites. a: The ring-shaped Gardiner complex seen from the air, with the inner ring in the foreground (see Fig. 12 for location: viewpoint approximately over Batbjerg, looking west). b: Layered melilite rock (uncomphagrite) from the Gardiner ring dyke as described by Nielsen (1980). Dark layers are perovskite. Yellowish colouring on the weathered surface may be due to cebollite, an alteration product of mellite. c: Photomicrograph (crossed polarizers) of olivine nephelinite dyke rock from the Batbjerg area, similar to material described by Brooks \& Rucklidge (1974). Field of view $4 \mathrm{~mm}$. d: Large, well-formed magnetite crystals, Gardiner complex. e: Bronze-coloured baryto-lamprophyllite, Gardiner complex, as described by Johnsen et al. (1994). f: Photomicrographs of ijolite from Sulugssut consisting largely of nepheline and augite rimmed by a Na-rich variety of clinopyroxene. Field of view 2 mm. Left: plane polarised light. Right: crossed polarisers. g: Photomicrograph (plane polarised light) of phlogopite-rich nephelinite dyke-rock with a large mantled olivine, the Sulugssut complex (Brooks et al. 1989). Field of view $4 \mathrm{~mm}$. h: Silico-carbonatite vein cutting gneiss at Tuttilik. 


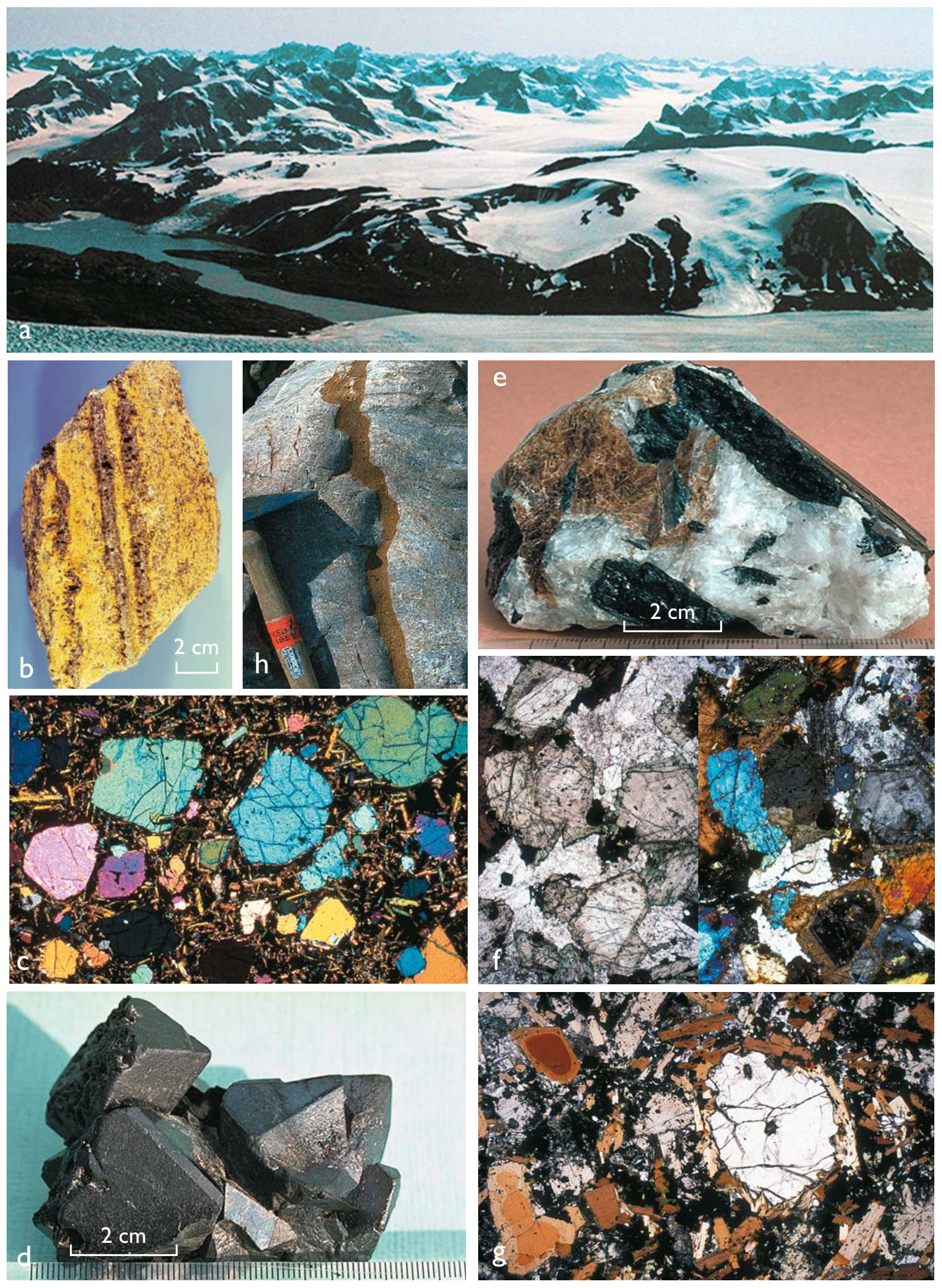


linite magma, in which early crystallisation of olivine and pyroxene led to the formation of the voluminous early cumulates (Fig. 18c; Nielsen 1994). Further fractionation under conditions of both high and low fluid partial pressures and probably carbonatite immiscibility led to a variety of products, including melilitites, agpaitic phonolites and carbonatites. The intrusion apparently vented and dispersed phonolitic ashes over a very wide region (Heister et al. 2001), as described above. Melanephelinitic and related compositions, which are likely parent magmas of the Gardiner complex, not only occur as dykes in the area, but also as lava flows at Lindsey Nunatak (Nielsen 2001; Peate, D.W. et al. 2003). Loose blocks of nephelinite from raised beaches within the Skaergaard area were described by Brooks \& Rucklidge (1974) although it cannot be said whether these originated in flows or dykes. Spectacular tinguaites with $\geq 1 \mathrm{~cm}$ large phenocrysts of nepheline besides alkali feldspar and katophorite, in a finegrained matrix rich in aegirine needles, occur in the same beach assemblage and probably also belong to this same genetic family.

The Gardiner complex is noted for its museumquality mineral specimens as described by Johnsen et al. (1985). These include magnetite (Fig. 18d), titanite, melanite (garnet), perovskite and apatite, all of which occur in large, well-formed crystals. Gem quality titanite has also been recorded. Detailed descriptions of titaniferous clinohumite (Nielsen \& Johnsen 1978) and lamprophyllite/barytolamprophyllite, see Fig. 18e, have also appeared (Johnsen et al. 1994).

${ }^{40} \mathrm{Ar} /{ }^{39} \mathrm{Ar}$ dates from the Gardiner complex indicate two periods of activity at $56.5 \pm 0.3 \mathrm{Ma}$ and $54.7 \pm$ 1.2 Ma, probably corresponding to the field observations of early ultramafic cumulates and later ring dykes. The uncertainties arise because the ultramafic cumulates are not amenable to direct dating and only supposedly comagmatic rocks have been dated. These ages correspond to unpublished data by L.E. Heister (2001) and Rb-Sr ages of $56.35 \pm 0.24,56.2 \pm 2.4$ and $56.14 \pm 0.24 \mathrm{Ma}$ by Waight et al. (2002), which were measured in situ using multicollector ICP-MS and generating clinopyroxene-biotite, apatite-biotite and apatite-clinopyroxene-biotite isochrons, respectively. The sanidine-bearing tuff on the Gronau nunataks $c .100$ $\mathrm{km}$ to the west (see previous section on long-distance tephra falls), thought to be sourced at the Gardiner complex, gives $55.0 \pm 0.3 \mathrm{Ma}$, the same, within error, as the second period of intrusion at Gardiner (Heister et al. 2001). Ages of $55.0 \pm 0.4 \mathrm{Ma}$ (sanidine) and $55.1 \pm$
$0.5 \mathrm{Ma}$ (whole rock) were obtained on the same sample of this tuff by Storey et al. (2007b, without acknowledging the earlier determination). Within error this is the same age as petrographically similar tuffs from the North Sea, Denmark, the London Basin and Deep Sea Drilling Project Hole 550, as reported by Heister et al. (2001). Similar ages were also presented by Westerhold et al. (2009). As previously discussed, this a very important marker horizon for the entire North-East Atlantic.

There is also a Lu-Hf age for the Gardiner complex, using an apatite-whole rock isochron (Barfod et al. 2003). However, the decay constant was poorly known at the time and the age was given as either $53.53 \pm 0.53$ $\mathrm{Ma}$ or $51.84 \pm 0.51 \mathrm{Ma}$. The decay-constant problem now seems to be resolved (Thrane et al. 2010) but the date still diverges from the others as it gives a value close to the younger estimate.

A second nephelinitic intrusive centre, the Sulugssut complex, lies some $200 \mathrm{~km}$ to the south (Fig. 2). This is much less well known as only a short 'discovery paper' has appeared (Brooks et al. 1989), but it contains ijolites (Fig. 18f) and minor carbonatites. It is associated with intense dyke swarms in which tinguaites are prominent. They are aegirine-rich, both aphyric and with prominent nepheline, alkali feldspar and often titanite phenocrysts. Nephelinites with mantled olivine also occur (Fig. 18g). Dykes probably related to this centre occur at Tuttilik to the south (Rucklidge et al. 1980). Here are also found silico-carbonatite veins containing phlogopite and altered olivine (Fig. 18h), which have been dated by Storey et al. (2007b) at $58.3 \pm 0.9$ $\mathrm{Ma}$ (two samples with identical results), considerably older than the Gardiner complex. However, a gabbro from the Sulugssut complex has given ages of $53.25 \pm$ $0.27 \mathrm{Ma}$ (plateau age) and $53.30 \pm 0.35 \mathrm{Ma}$ (L.E. Heister, personal communication 2001). Further work is needed to establish the relations between these nephelinitic/carbonatitic occurrences.

A similar age was reported for a nephelinite flow at the base of the volcanic succession at Hold with Hope at $74^{\circ} \mathrm{N}$ by Upton et al. (1989), although there is some doubt as to whether this might be a sill rather than a flow, as noted earlier (B. Upton, personal communication 1998).

Within the plateau basalt area, a number of nephelinite vents were reported at Sorte Bræ by the Danish Lithosphere Centre and they give a ${ }^{40} \mathrm{Ar} /{ }^{39} \mathrm{Ar}$ age of $50.2 \pm 1.2 \mathrm{Ma}$ (Tegner et al. 2008). Nephelinite dykes have been reported from the interior of Scoresby Sund and, as already noted, as an isolated pyroclastic horizon 
at the base of the Rømer Fjord formation (Larsen, L.M. et al. 1989), which must have an age of c. $55.4 \mathrm{Ma}$, judging by its position within the basalt stratigraphy.

To the north at about $74^{\circ}$ small flows and vents of highly alkaline lavas (melilitites, nephelinites and basanites) occur on the inland nunataks (Fig. 2). These have been described by Katz (1952a, b), Brooks et al. (1979), Bernstein et al. (2000) and Harlou (2001) and have an age of $c .56 \mathrm{Ma}$. They are in a pristine state of preservation, lack zeolites, appear never to have been buried and are found today in an environment where chemical weathering is close to zero as the temperature at this altitude $(>1000 \mathrm{~m})$ rarely rises above zero. They have exceptionally high contents of Ti (up to 9\%; similar rocks are only reported from Bermuda. A description of the latter rocks by Bernard Gunn was never published but may be found at http://www.geokem.com/ OIB-volcanic-atlantic.html\#Bermuda; (these same Bermuda drill cores have also been studied in a master's thesis by Olsen 2005). These nunatak rocks were originally thought to be related to the Jan Mayen Fracture Zone as they fall near its extrapolation into the continent (Brooks et al. 1979), a conclusion supported by Torske \& Prestvik (1991), see below.

\section{Nephelinite genesis}

Several authors (Marsh 1973; Sykes 1978; Garson \& Krs 1976; Williams \& Williams 1977) have remarked on the localisation of kimberlites, melilitites, nephelinites, etc. on the landward extensions of transform faults in the adjacent ocean basins. Indeed, in the North Atlantic area Torske \& Prestvik (1991) argued by that the Vestbrona nephelinites on the Norwegian shelf (Møre Platform, Fig. 1) are found on an extension of the Jan Mayen Fracture Zone, following Brooks et al. (1979) who suggested that the nephelinites of the Nunatak Zone of East Greenland lay on the extension at the other end of this fracture zone. It is important to remember, however, that offshore structures are subject to interpretation. For instance, a series of apparent riftoblique transform faults in the Faroe-Shetland basin were, on closer inspection, shown to be caused by different processes including igneous intrusion (Moy \& Imber 2009).

Larsen, H.C. (1990) pointed out that the East Greenland shelf is segmented into distinct morphological regions characterised by differences in crustal type, contrasting basement tectonics, subsidence history and different timing of basin formation (Fig. 19). These regions are separated by boundaries which appear to be some type of accommodation zones, which are, from south to north (Fig. 19): the Denmark Strait Escarpment Zone at about $66^{\circ} \mathrm{N}$ (perhaps corresponding to the South Iceland Seismic Zone at the present time), the Kangerdlugssuaq Escarpment Zone at about $68^{\circ} \mathrm{N}$ (corresponding to the Tjörnes Fracture Zone today and perhaps the 'Faroe transform fault' of Bott 1987), the Scoresby Sund Fracture Zone at about $70^{\circ} \mathrm{N}$ (Spar Fracture Zone) and the Jan Mayen or Kong Oscar Fjord Fracture Zone at about $73^{\circ} \mathrm{N}$. On the basis of their limited distribution it seems very possible that the nephelinites, melilites and carbonatites of East Greenland are related to these structures. Sykes (1978) was of the opinion that oceanic fracture zones initiate at pre-existing weak zones in the continental lithosphere. This may determine the primary segmentation of the early rift, similar to that seen in East Africa as described by Rosendahl (1987; see also Karson \& Brooks 1999, p. 334). It is clear that this suggestion concerning the distribution of nephelinites is wholly speculative and needs further work to be substantiated, and the absence of reports of nephelinites in the intervening areas does not necessarily mean they are not present, perhaps simply that they have not yet been found. A good test for the suggestion would be if nephelinites were found where they might be predicted, although no further discontinuities were mapped by Larsen, H.C. (1990). If the average distance between the mapped zones is projected to the south it is to be expected that nephelinites might be found near Ammassalik and further at Umivik. However, none have yet been reported, with the exception of a nepheline syenite block at the old British Arctic Air Route Expedition's base at Nattivit, west of Tasiilaq (formerly Ammassalik) (unpublished observation by the author).

Nephelinites and melilitites form by small degrees of melting at relatively great depth. Despite their small volume, these melts may have a significant role to play as they can potentially provide information about regions of the mantle that may not have been tapped by other magmas. Furthermore, they are highly enriched in incompatible elements so that their signature would be very marked if mixed with other magmas, even in small fractions. They may in fact represent the enriched component of the Icelandic mantle plume as suggested by Bernstein et al. (2001). These authors suggested that 


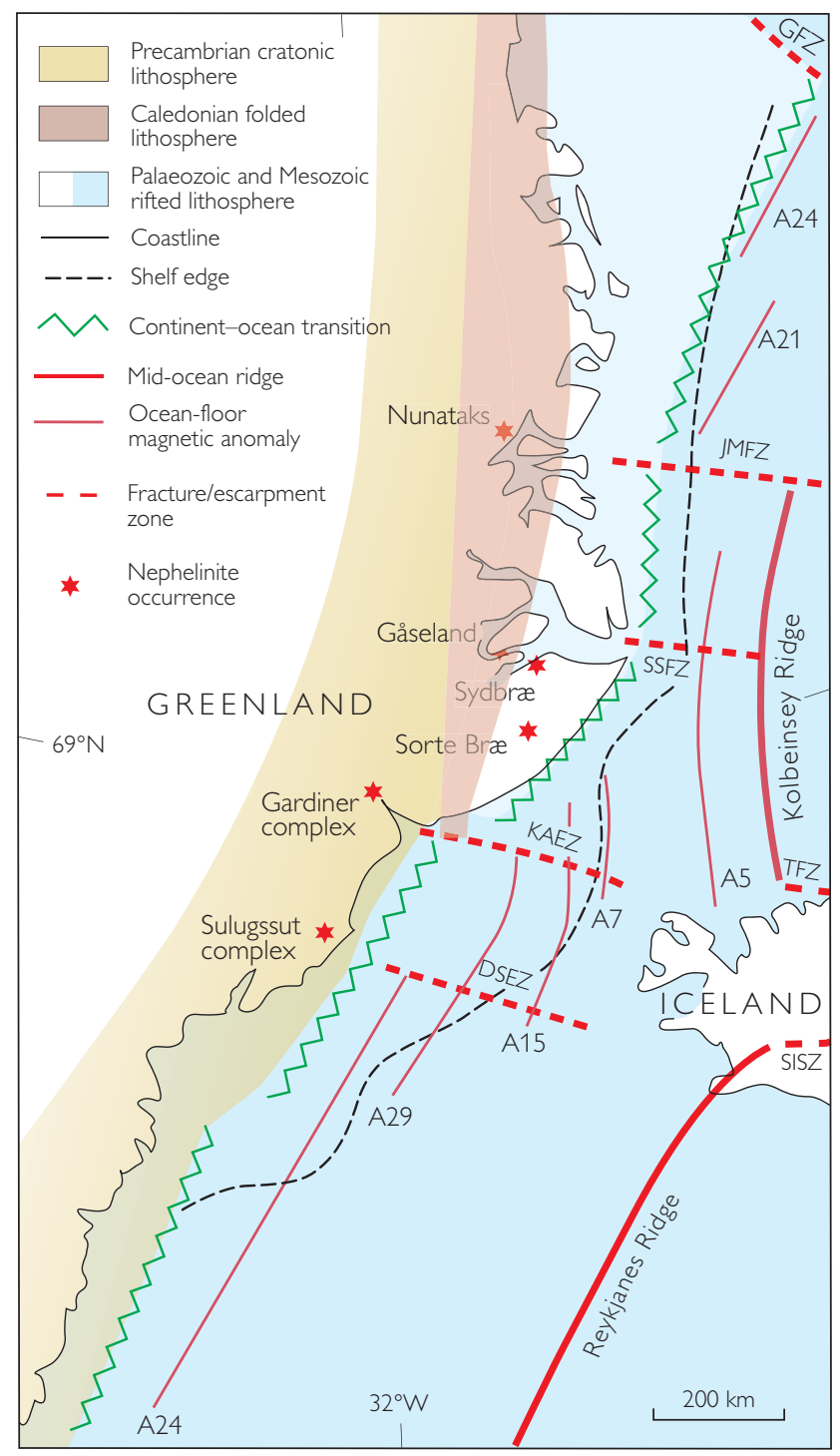

Fig. 19. Map of the East Greenland margin, showing offshore features and, schematically, onshore geology. Redrawn after Larsen, H.C. (1990). GFZ: Greenland Fracture Zone. JMFZ: Jan Mayen Fracture Zone. SSFZ: Scoresby Sund Fracture Zone. KAEZ: Kangerlussuaq Escarpment Zone. DSEZ: Denmark Strait Escarpment Zone. TFZ: Tjörnes Fracture Zone. SISZ: South Iceland Seismic Zone. The SISZ and TFZ are presumed to be the modern equivalents of the DSEZ and the KAEZ, respectively. Larsen, H.C. (1990) stressed that major structural and stratigraphic changes take place across these zones as shown by aeromagnetic and reflection seismic mapping. Positions of the main nephelinite occurrences in East Greenland are shown with stars; a relationship to the zones is postulated. Basalts are not shown. a subducted oceanic slab might be involved, as required by those who deny mantle plumes (Foulger et al. 2005).

On present evidence, nephelinite magmatism seems to have been sporadic throughout the period of basaltic extrusion and no definite nephelinite event is apparent.

\section{Dykes and sills}

Cenozoic dykes and sills are ubiquitous in East Greenland. Precambrian dykes also occur cutting the gneisses, but these are easily distinguished by their metamorphic textures and commonly by the presence of garnet. In the Caledonian areas north of Scoresby Sund, dykes of intermediate ages may also occur but are more difficult to recognise. The mica-rich monchiquite dykes of Liverpool Land referred to earlier (Kofoed 1998) are an example. Perplexing lamprophyre dykes described by Larsen, P.-H. et al. (1990) are apparently truncated by Upper Permian sedimentary strata, which also contain clasts identified as coming from the dykes. Nevertheless, the dyke rocks yield Palaeogene ages. This phenomenon was explained by water-rich sedimentary rocks arresting the dyke intrusion.

Cenozoic dykes occur in many generations. Some are intense, such as the coastal dyke swarm that cover almost $90 \%$ of the ground in extreme cases, while others are relatively sparse with spacings of many metres. Some generations are regional (notably the coastal dyke swarm), whereas others are localised and associated with igneous centres, such as is probably the case with the 'Late Dykes' described by Brooks \& Platt (1975). These dyke generations record episodes of crustal extension and changing magma compositions. In favourable circumstances, they can be placed into a relative chronological order by observing cross-cutting relationships both with each other and with their host rocks. Sometimes the intensity of dyking and exposure can make the relationship between dykes very challenging to identify. It is not unusual to find dykes in areas of almost $100 \%$ exposure where precisely the intersection point is concealed by regolith. Radiometric dating, likewise in favourable circumstances, can then place these generations into the absolute time scale. Dykes therefore play a key role in documenting the tectonic and magmatic evolution. An exemplary study was that of Nielsen (1978) of the dykes at Kangerlussuaq.

Wager \& Deer (1938) made East Greenland famous for its dyke swarm and flexure (Fig. 20a, shown sche- 

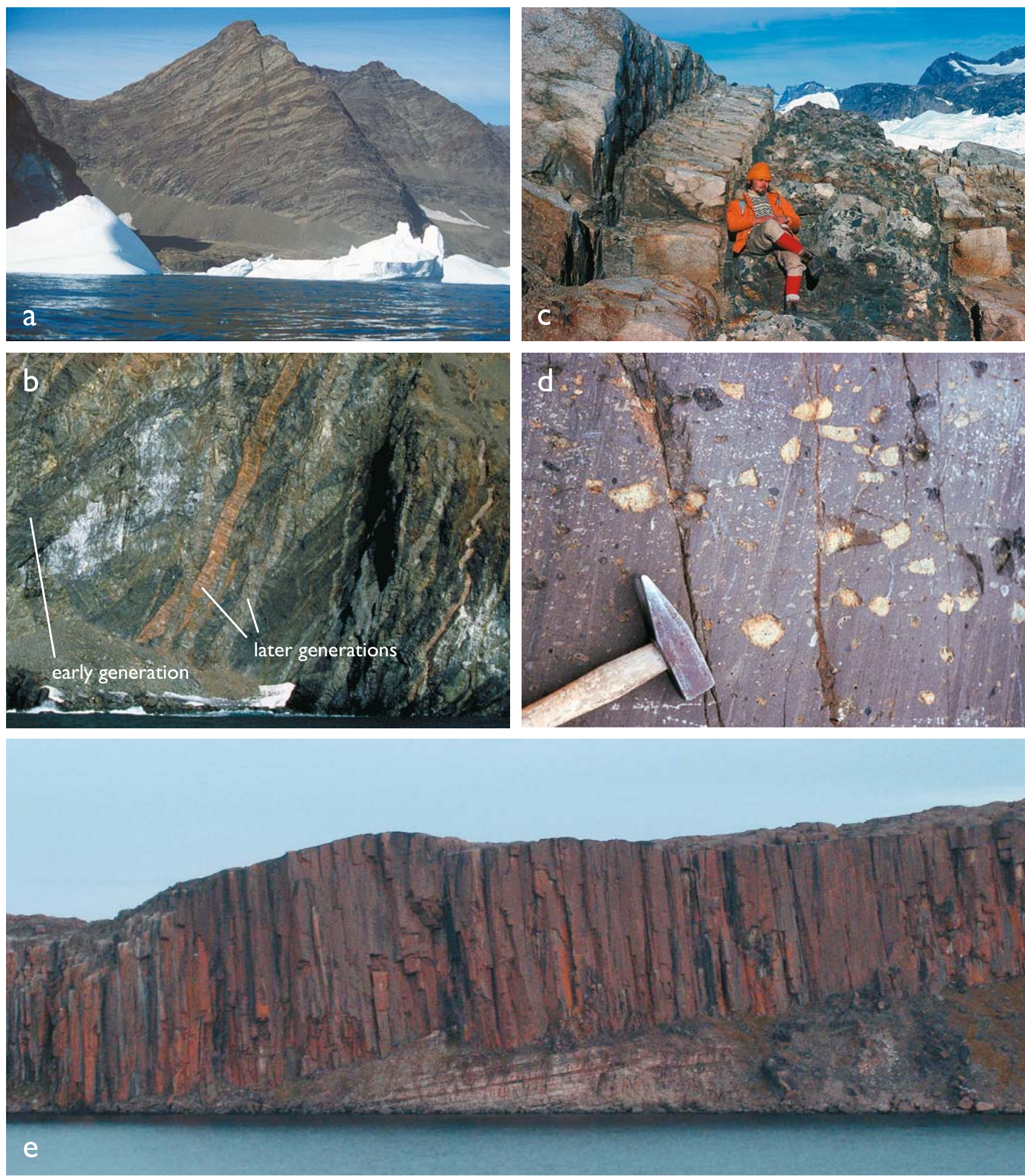

Fig. 20. Dykes. a: Coastal dyke swarm on the outer coast near Miki Fjord. Note: apparent dips are distorted due to the orientation of the section. b: Detail of the coastal dyke swarm at Hængefjeldet as described by Nielsen (1978). c: Composite, $c .6 \mathrm{~m}$ wide dyke at Bagnæsset. The outer parts are moderately potassic basanite and xenolith-free. The inner unit is crowded with a variety of kaersutite-bearing nodules and megacrysts likely representing an underlying cumulate body. $\mathbf{d}$ : Dyke at Wiedemann Fjord containing occasional kaersutite megacrysts and numerous harzburgite nodules from the sublithospheric mantle. e: Dolerite sill with palisade jointing on southern Gauss Halvø. Dolerite sills are ubiquitous in the entire area of sedimentary basins. 
matically in Fig. 21). Similar dyke swarms are associated with flexures in the Deccan and Karroo provinces in India and southern Africa, respectively. In this platetectonic era, it is clear that this structure represents the continental margin, where the dykes are equivalent to the sheeted dyke swarm present along mid-ocean ridges (e.g. Karson et al. 1992) and that the flexure is a faulted structure bounding the newly formed rift. Thus the term flexure, which suggests ductile deformation, is misleading. The dykes and sills are clearly a consequence of the extension and collapse of the continental margin (and are thus discussed again in several sections below). They also document the sometimes subtle changes in magma compositions with time.

Later studies of the dyke swarms in East Greenland and the flexure associated with the coastal swarm have been made by Nielsen (1975, 1978), Myers (1980),
Nielsen \& Brooks (1981), Karson \& Brooks (1999), Callot et al. (2001, 2002), Klausen \& Larsen (2002), Klausen (2006) - all largely structural in approach; Gill et al. (1988), Hanghøj et al. (2003) - largely chemical; and by Tegner et al. (1998b), Lenoir et al. (2003), Holm et al. (2006) - geochronological. Some dykes in the Wiedemann Fjord area carry highly depleted lithospheric mantle nodules, which have been described by Brooks \& Rucklidge (1973), Bernstein et al. (1998a, 2006, 2007) and Hanghøj et al. (2001). Studies of specific groups of dykes were made by Brooks \& Platt (1975) on the dyke swarm to the west of Kangerlussuaq known as the 'Late Dykes' and the dykes at Tuttilik (previously Tugtilik) just south of $66^{\circ} \mathrm{N}$ (Fig. 2; Rucklidge et al. 1980). Dykes that have suffered Ca metasomatism were described by Rose \& Bird (1994).
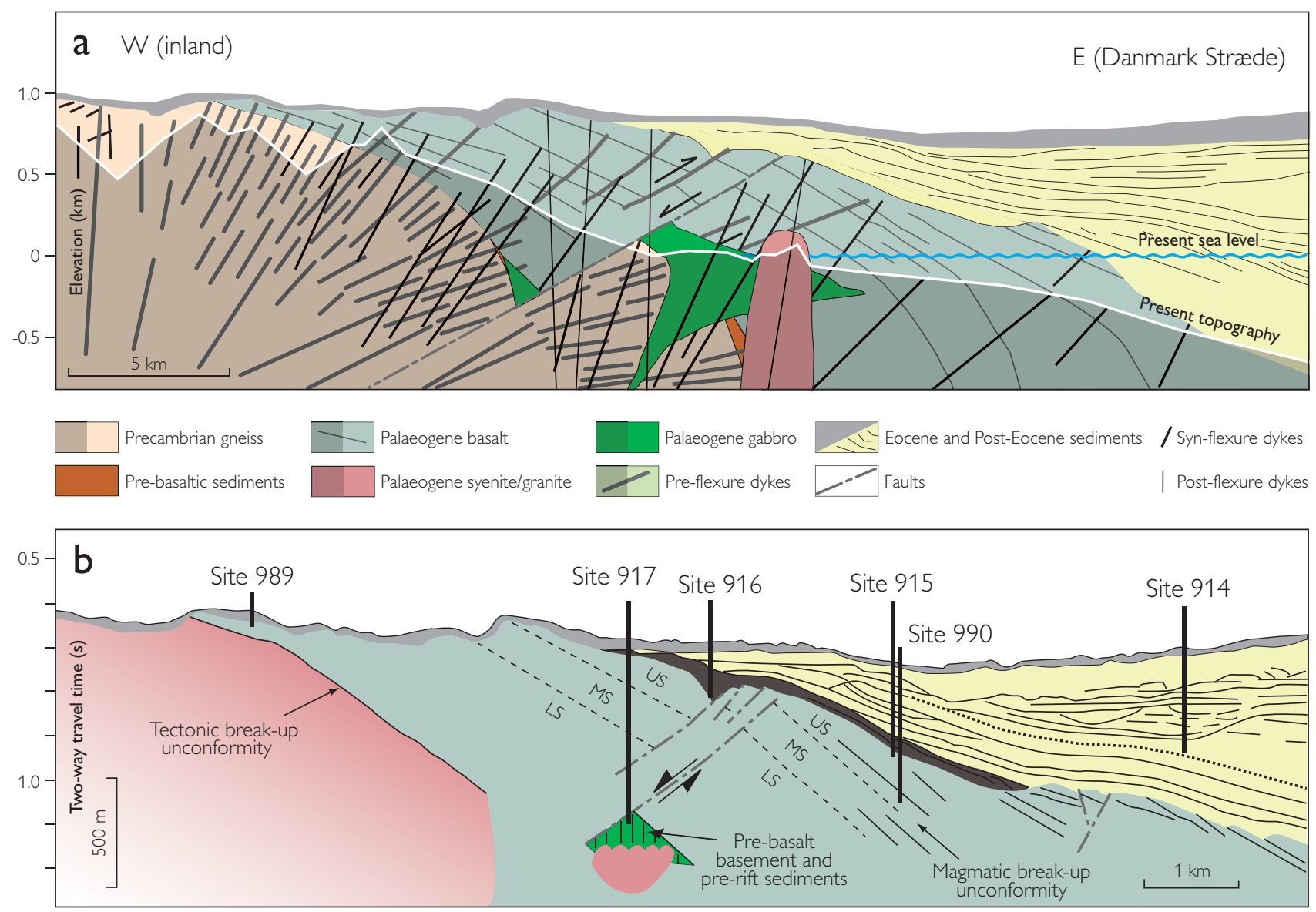

Fig. 21. The coastal flexure of the East Greenland continental margin. a: Diagrammatic cross-section of the East Greenland margin, showing flexured basalts and gabbros, numerous dyke generations and late felsic intrusions. b: Interpreted seismic section across the margin showing some of the sites drilled on Legs 152 and 163 of the Ocean Drilling Program. Redrawn from Larsen, H.C. \& Duncan (1996). LS, MS and US refer to Lower, Middle and Upper Series basalts. 
In a classic paper Wager and Deer (1938) described the coastal dyke swarm as following the coast for over $800 \mathrm{~km}$ from near Scoresby Sund to Tasiilaq. Larsen, H.C. (1978) discussed the offshore extensions of this swarm. Wager \& Deer (1938) noted a constant relationship between three factors: the dip of the lavas, the density of the swarm and the dip of the dykes. Thus, the densest part of the dyke swarm occurs where the lavas have the steepest dip, i.e. close to the coast. The dykes are nearly perpendicular to the lavas over the entire width of the swarm, suggesting that they have been tilted along with their hosts. Wager \& Deer (1938) also noted that the coastal dyke swarm cuts the gabbros but not the syenites at Kangerlussuaq or the syenites, the net-veined complex and the alkali granites at Kialeeq, indicating its value as a time marker. The Skaergaard, Kap Edvard Holm and Imilik gabbros are all tilted by the flexure and cut by the associated dykes. Wager $\&$ Deer (1938) suggested that the flexure arose by loading and sinking of the crust by $7 \mathrm{~km}$ of basalt and accentuated by melting and migration of sial to the west causing inland uplift, a model now obsolete.

In his first paper, Nielsen (1975) described the structure of the coastal belt, distinguishing early dykes, tilted seawards (i.e. landward-dipping) and later dykes with a more vertical attitude. These two major groups clearly bracketed the flexuring and break-up event. He further showed that the flexure involved considerable faulting, not a simple bending - the impression gained from earlier descriptions. Later studies (e.g. Karson \& Brooks 1999; Klausen \& Larsen 2002) have refined this work. In a detailed study of the dyke swarms of the Skaergaard intrusion area, Nielsen (1978) recognised at least four generations, the first two being tholeiitic, the third alkaline and the final one containing both transitional and alkaline members. Figure $20 \mathrm{~b}$ shows an example of the complexity. He was able to tie their intrusion ages to the plutonic events and set up an igneous stratigraphy spanning from $c .58$ to $c .36 \mathrm{Ma}$, using the then sparse radiometric data. On the basis of chemical similarities Gill et al. (1988) claimed that Nielsen's earliest dykes were contemporaneous with the Lower Basalts, which we now know to be $c$. $60 \mathrm{Ma}$ old. Using the same criteria they claimed that other dykes were largely feeders to the overlying plateau basalts. A much more detailed study of the elemental and isotopic compositions of the dykes was made by Hanghøj et al. (2003), although correlation with Nielsen's generations is not always apparent. Karson \& Brooks (1999) stressed the segmentation of the coastal region in the north-south direction, showing how the earliest phase of flexuring entailed considerable penetrative deformation including the formation of mylonites and pseudotachylites, dated by Karson et al. (1998) to $62.9 \pm 4.5 \mathrm{Ma}$ using laser heating techniques. These pseudotachylites are clearly evidence that at times the margin was magmastarved and the extension was largely tectonic. Later on, much more voluminous magmas were produced and extension was accomplished entirely by dyke injection as at normal mid-ocean ridges, and the tectonic deformation testified by the pseudotachylites ceased. Both tectonic and magmatic styles of extension are known from mid-ocean ridges. Klausen \& Larsen (2002) used statistical methods to reveal the structure of the dykes and the flexure, by showing the relation between dyke swarms and igneous centres, as in Iceland. Lenoir et al. (2003) dated tilted dykes at c. 55-54 Ma and vertical dykes at $c .51 \mathrm{Ma}$ at Kap Wandel $\left(66^{\circ} 20^{\prime} \mathrm{N}\right)$ and Kap Gustav Holm $\left(66^{\circ} 40^{\prime} \mathrm{N}\right)$ and were able to estimate a minimum strain rate, which suggested a high thermal gradient. Magnetic anisotropy studies (Callot et al. 2002) indicate that tholeiitic dolerites were injected by horizontal flow, as would be expected if they were fed from the major centres, as suggested by Klausen $\&$ Larsen (2002) and also similar to the horizontal flow documented for Krafla in Iceland (Björnsson 1985).

Probably the best site to study the present splitting of continental crust to form a new ocean is the Woodlark Basin of Papua New Guinea, which has been investigated by a variety of methods including drilling by the Ocean Drilling Program (Speckbacher et al. 2011 and references therein). Here, extension takes place along low-angle detachment faults with a kilometre-scale displacement prior to the inception of volcanism and the creation of new ocean-floor. These faults are associated with extensive cataclastites and mylonites and lubricated by talc, comparable to the deformed gneisses and hyaloclastites described from East Greenland by Karson \& Brooks (1999). Volcanism follows closely after this tectonic extension with the formation of new ocean floor. It may well be that the Woodlark area provides a useful modern analogue to the events that took place during the earliest phase of break-up in East Greenland.

There is a divergence of opinion regarding the precise mechanism for the emplacement of the East Greenland coastal dyke swarm. Wager \& Deer (1938) and Wager (1947) envisaged the dykes as being intruded in a fan-shaped array in association with the flexuring; while Nielsen (1975) considered that the dykes were in- 
truded vertically in the basalt pile and then tilted by the flexuring. Faller (1975) and Faller \& Soper (1979) carried out palaeomagnetic measurements in the Miki Fjord - Irminger Fjord area and found that their results precluded later tilting of the dykes and that they were intruded in their present orientation. This question remains unsolved, mainly because of the high levels of alteration in the area sampled by Faller \& Soper (1979) and also because it was not appreciated at the time that the basalts in this area (Lower Basalts) were appreciably older than the dykes cutting them. It is thus suspicious that the dykes and the flows have the same palaeomagnetic directions and that these are also the same as the youngest flows in the Main Basalts as reported by Tarling (1967) and Hailwood (1977).

A suite of dykes trending roughly $\mathrm{N}-\mathrm{S}$ in the middle reaches of the western side of Kangerlussuaq (Fig. 20c, known as the 'Late dyke swarm' as it cuts everything else in the area) was studied by Brooks \& Platt (1975). These dykes make up a differentiated mildly potassic suite and are remarkable for their kaersutite-bearing xenoliths, often in large size and quantities. Brooks \& Platt (1975) concluded that they are evidence for a major layered kaersutite gabbro intrusion under this area. Some dykes here are as young as $35 \mathrm{Ma}$ (Gleadow $\&$ Brooks 1979). There are outcrops of a kaersutitebearing dioritic rock, often rich in large crystals and aggregates of pyrite, on the ridge between Sdr. Syenit Gletscher and the crags on the south side of Ndr. Syenit Gletscher, which may be part of this otherwise buried body. The possibility that the quartz porphyries of Flammefjeld are related to this blind intrusion should be examined. Brooks \& Platt (1975) showed that such oversaturated, silicic magmas could be generated by fractionation of amphiboles, which are relatively silicapoor.

Dykes cutting the Skaergaard intrusion were described by Vincent (1953). They range from dolerites to camptonites (hornblende lamprophyres), which appear very prominent due to light weathering colours. Vincent (1953), whose samples were collected within a restricted area in the south-western part of the intrusion, was unaware of the comendites which cut the northern part of the intrusion (Brooks \& Rucklidge 1976). These comendite dykes are $c .1 \mathrm{~m}$ thick and are of two types. One contains phenocrysts of quartz, alkali feldspar and amphibole in an aegirine-rich groundmass. The bulk of the dyke is not peralkaline and buff-coloured in outcrop, whereas the margins are peralkaline and bluish in outcrop. The more slowly cooled, buff material has clearly lost alkalies, and in a thin section, the arfvedsonite needles of the margin are seen to be oxidised. The other type of dyke is aphyric. It is bluish over the entire width, due to high levels of acicular alkali amphibole in the groundmass, and is markedly spherulitic. In the porphyritic dykes it is thought that crystallisation has been caused by seeding on the contained crystals, whereas this has not taken place in the aphyric varieties, which were quenched below the glass transition and devitrified over time. Where such dykes cut the gabbros of the Skaergaard intrusion the adjacent gabbros have been strongly bleached over a few centimetres. These dykes are thought to be related to the Kræmer $\varnothing$ syenite. Similar dykes occur throughout East Greenland, e.g. associated with the Kap Simpson/ Kap Parry intrusions to the north (Schaub 1942).

An orbicular-structured comendite, belonging to the aphyric group, was described by McBirney et al. (1990) as an example of self-organisation. They referred this dyke to the Skaergaard transgressive granophyres although peralkaline dykes of this type are quite common in the northern part of the intrusion and its host rocks and appear to radiate from the Kræmer $\varnothing$ syenite.

One prominent very early dyke cutting the Skaergaard intrusion contains gabbroic xenoliths thought to represent deeper, unexposed levels of the intrusion (Irvine et al. 1998; Jakobsen et al. 2010). Compositionally, it resembles the postulated Skaergaard initial liquid.

Of major interest are dykes at Wiedemann Fjord on Blosseville Kyst. Two of these dykes, occurring in the north-south fractured zone of basalts mentioned previously, have been dated at $41.5 \pm 0.9$ and $36.6 \pm$ $0.5 \mathrm{Ma}\left({ }^{40} \mathrm{Ar} /{ }^{39} \mathrm{Ar}\right.$, Tegner et al. 2008). The dykes are camptonites and perhaps also monchiquites, and some contain a suite of amphibole/pyroxene megacrysts and nodules of strongly depleted harzburgite (Brooks \& Rucklidge 1973; Fig. 20d), which were shown by Bernstein et al. (1998a, 2006, 2007) to represent residues from partial melting in which komatiitic magmas were produced. The nodules give a unique indication of the nature of the subcontinental lithosphere in this region, and are unique in the North Atlantic Igneous Province with the exception of similar material collected from Ubekendt Ejland, West Greenland, where they occur in a basanitic lava flow younger than $52.5 \mathrm{Ma}$ (Bernstein \& Brooks 1998). Using osmium isotope model ages Hanghøj et al. (2001) were able to confirm that the melting event generating komatiites took place in the Archaean. Similar material has been described from kimberlites and ultramafic lamprophyres in West 
Greenland and Canada (Bizzarro \& Stevenson 2003; Wittig et al. 2008).

Other dykes to be found are composite dykes with mafic margins and felsic interiors, common in Kialeeq, and felsic dykes with mafic pillows, observed at Kap Boswell and Kruuse Fjord. Many of the syenites contain synmagmatic dykes, i.e. dykes broken up to variable extents as they were intruded into the still unconsolidated host.

Sills and sill complexes are common in the areas of sedimentary rocks. The two most prominent host areas are the Jameson Land basin at Scoresby Sund and the Sorgenfri Gletscher area of the southern Blosseville Kyst, although sills occur throughout the sedimentary basins of north-east Greenland (Fig. 20e). Extensive sills also occur on Traill $\varnothing$ accompanied by a small outcrop of basalt (Hald 1996). The Jameson Land suite of sills and dykes, trending ESE, has been described by Larsen, H.C. \& Marcussen (1992) and Hald \& Tegner (2000). These sills are mainly evolved plagioclaseaugite-olivine-phyric tholeiites, and are cut by alkaline dolerite sills and dykes in Jameson Land. Surprisingly, this sill complex post-dates the plateau basalts by $2-5$ $\mathrm{Ma}$ and the initiation of sea-floor spreading by 1-2 Ma. The Sorgenfri Gletscher sill complex (Wager 1947), which intrudes the sedimentary rocks of the Kangerlussuaq basin, has been studied in a $\mathrm{PhD}$ thesis (Gisselø 2001). Individual sills may be several hundred metres thick. They are of tholeiitic composition and can be compositionally matched in the plateau basalts, and ${ }^{40} \mathrm{Ar} /{ }^{39} \mathrm{Ar}$ dating shows that they are contemporaneous with the basalts (Tegner et al. 1998b). There are also a number of syenitic sills in this area, which corresponds to a dome-shaped area of high palaeo-temperatures revealed by fission-track studies (Hansen \& Brooks 2002, see Fig. 22). A specimen containing aegirine and arfvedsonite from a nunatak that has recently emerged from the ice at the snout of Sorgenfri Gletscher (Fig. 2) was described by Brooks (1991a). The age of these sills has already been given in the syenite section above. Similar sill complexes have been noted by several authors (e.g. Hansen 2006) from the conjugate margin in the Rockall, Faroe-Shetland and Møre basins. Hansen (2006) showed that their intrusion took place in several events. This led to venting through the overlying sedimentary rocks, which was proposed by Svensen (2004, 2010) to have led to massive methane additions to the atmosphere and caused the Paleocene-Eocene Thermal Maximum (see also the section, Time frame for magmatism and margin deformation).
Cutting the Skaergaard intrusion and the coastal area to its south are some large sills, which have been described by Hughes (1956), Douglas (1964) and Naslund (1989). The Basistoppen Sill which cuts the Skaergaard intrusion (originally interpreted as a raft of basalt by Wager \& Deer 1939), is $660 \mathrm{~m}$ thick and displays one of the most complete differentiation sequences known, comparable to those of the Skaergaard and Bushveld intrusions. This may be because of intrusion into a hot host with consequent slow cooling. Its margins also show rheomorphic effects. Recent, highly precise ${ }^{238} \mathrm{U} /{ }^{206} \mathrm{~Pb}$ zircon dates, using the ID-TIMS method, show that the sill was intruded $125 \pm 85 \mathrm{ka}$ before the closing temperature for zircon of the Skaergaard intrusion's Sandwich Horizon: the uppermost unit of the Layered Series (Wotzlaw et al. 2011).

Large dykes up to $1000 \mathrm{~m}$ thick also occur in the Skaergaard area. They are termed macrodykes and have been described by Bird et al. (1985), White et al. (1989), Blichert-Toft et al. (1992), Geist \& White (1994) and Momme \& Wilson (2002). They are thought to be comagmatic with the Skaergaard intrusion and show layering, abundant xenoliths and autoliths, rheomorphic effects (e.g. Naslund 1986) and development of granophyres and pegmatites. The Kræmer $\varnothing$ macrodyke was interpreted by Momme \& Wilson (2002) as a feeder to the overlying basalts. The Miki Fjord and Vandfaldsdalen macrodykes have been the subject of studies of reaction and hybridisation with the country rocks (Rosing et al. 1989; Blichert-Toft et al. 1992; Waight \& Lesher 2010), which have implications on the mechanism of contamination seen in some of the lavas, particularly the Lower Basalts. These macrodykes also contain interesting concentrations of noble metals (Brooks et al. 1987) and have recently become the target of mineral exploration by Platina Resources Limited.

A suite of dykes described by Brooks \& Nielsen (1982b) is also comagmatic with the Skaergaard intrusion. These dykes contain granophyric veins with a composition similar to plagiogranite of ophiolites (C.K. Brooks, unpublished data) and were used to illuminate the early phases of compositional development of the Skaergaard intrusion's magma.

Two other types of dykes should also be noted, namely a group bearing gneiss xenoliths discussed by Bird et al. (1985) and those bearing green, often spectacular rosettes of prehnite up to $3 \mathrm{~cm}$ across (Bird et al. 1985; Rose \& Bird 1994; see also below). The gneiss-bearing dykes were thought to follow the E-W topographic low 
along Forbindelsesgletscher in the Skaergaard intrusion, inner Miki Fjord and the glacier between Miki Fjord and I.C. Jacobsen Fjord. The metasomatic processes taking place in the prehnite-bearing dykes have been examined in detail by Bird et al. (1985) and Rose \& Bird (1994).

The coast-parallel dyke swarm and the closely associated coastal flexure are critical to an understanding of precise break-up mechanisms, as addressed in many of the references cited above. The seaward increase in the intensity of dykes and their increasing dip are a striking example of extension and continental margin collapse during continental rifting. The lack of a similar dyke swarm on the conjugate margin suggests that break-up was asymmetric as was suggested by Wernicke \& Tilke (1989) to be the case for the eastern North American margin. However, as the conjugate margin is submarine, exploration is incomplete and such structures are difficult to identify by geophysical methods.

The presence of pseudotachylites, sometimes in abundance, indicates that at times extension was largely tectonic, rather than magmatic. Observations suggest that the pseudotachylites were formed at an early stage of rifting before large volumes of magma were available, as seen in the Woodlark Basin referred to above, but the pseudotachylites and their relations deserve a more detailed study. The Woodlark Rift is strongly asymmetric. Recently the East Greenland margin and its conjugate Hatton Bank margin (west side of Rockall Plateau, Fig. 1) were investigated by White \& Smith (2009), who confirmed the asymmetry. They suggested that this may have started at an early stage before copious amounts of magma were available, and that the structure was at this time similar to non-volcanic margins, which are conspicuously asymmetric. Whether the rift is symmetric or asymmetric has important implications for the break-up and subsequent spreading. Finally, the segmentation of the margin as described by Myers (1980), Karson \& Brooks (1999) and Klausen \& Larsen (2002) and shown in Fig. 19 gives a powerful insight into the nature of continental break-up and invites comparison with segmentation of the mid-ocean ridges (MacDonald et al. 1991) and continental rifts (e.g. Rosendahl 1987; Beutel et al. 2010).

To summarise, the dykes of East Greenland are important because they provide time markers, indications of the directions and times of extension as well as the changing compositions of the magmas. Furthermore, they sample unexposed material from the subcontinental lithosphere, from concealed intrusions and from unexposed crust (many dykes in areas of basalt contain gneissic inclusions). Much of the history of the margin can thus be interpreted from the dyke swarms.

\section{Hydrothermal activity}

Patches of intense hydrothermal alteration are to be found in association with the subvolcanic complexes of the Mesters Vig area (Figs 14a, 15) and in particular at the Malmbjerg molybdenum deposit. Likewise, the Flammefjeld molybdenum deposit at Kangerlussuaq owes its name to the bright red and yellow colouring of the mountain top due to hydrothermal alteration. This is probably to be expected as intrusions north of Scoresby Sund were emplaced into sediments and would readily have set up hydrothermal systems, whereas this does not happen when the country rocks are gneiss of low permeability, as documented for the Skaergaard intrusion (Norton \& Taylor 1979; Taylor \& Forester 1979). Flammefjeld thus seems to be an exception.

Basalts also are reasonably permeable on a macroscale and may be cut by hydrothermal veins. Bright red calcitic veins, up to several metres wide, cut the basalts sporadically throughout the area (e.g. on the low rocky outcrops beyond the head of Wiedemann Fjord, see Fig. 6h). The ability of basalts to support hydrothermal systems has been documented by Manning \& Bird (1991, 1995) and Manning et al. (1993). High permeability is maintained via the slaggy flow tops and bottoms, until it is eventually reduced by the deposition of zeolites and other minerals. Thus, hydrothermal circulation in the basaltic pile has led to the zeolite zonations described by Neuhoff et al. (1997) referred to above. Copper-prehnite-calcite assemblages (Bird et al. 1985) belong to greatest depths exposed and native copper may occur in vesicles in the basalts, associated with calcite, prehnite, etc. Such copper seems to have been utilised by the Inuit, as artefacts from a recently found house site at Søkongen $\varnothing$ just south of Nansen Fjord include small copper rivets fastening baleen strips that bind coopered vessels. These abundant artefacts were found by the hunter Asser Johansen and are now in the National Museum in Nuuk. To the author's knowledge this indigenous use of native copper in Greenland has not been commented in the literature, although the use of meteoric and telluric iron is well known (Buchwald $\&$ Mosdal 1985). 
Following the pioneering work of Taylor \& Forester (1979) on the Skaergaard intrusion, numerous careful and detailed studies have illuminated the circulation of hydrothermal waters in the intrusions and their country rocks by mapping fracture systems and studying the mineral assemblages produced: e.g. Bird et al. (1985, 1986), Manning \& Bird (1986, 1991, 1995), Rose \& Bird (1987, 1994), Fehlhaber \& Bird (1991), Manning et al. (1993), Nevle et al. (1994) and Brandriss \& Bird 1999. The last of these publications studied some remarkable dolerite dykes, which had been subjected to Ca-metasomatism and contain gem-quality, green prehnite rosettes in their central parts, as referred to in the last section.

Showings of hydrothermal sulphides occur at a large number of places north of Scoresby Sund and have been described in a major monograph by Harpøth et al. (1986). Many of these are associated with the Palaeogene intrusions, such as Werner Bjerge, or are thought to be related to other Palaeogene activity. Others are of uncertain age, such as stratabound $\mathrm{Cu}-\mathrm{Pb}-\mathrm{Zn}$ deposits on Wegener Halvø. Similar sulphide occurrences are associated with the intrusions in the Kangerlussuaq area. In particular, base and precious metal veins with galena, sphalerite, chalcopyrite and tetrahedrite, related to the Flammefjeld pipe, were described by Thomassen \& Krebs (2001).

As the host rocks at Flammefjeld are also likely to be of low permeability, being syenites with large fracture spacing, the hydrothermal alteration and mineralisation are probably owed to an unusually water-rich magma. To recall a point made previously in the section on felsic intrusions, Flammefjeld is closely associated with an intrusive body that is rich in amphibole (kaersutite, as documented by Brooks \& Platt 1975) and therefore water-rich. The quartz porphyry magma is also likely to have been volatile-saturated although advanced alteration does not allow its primary mineralogy to be discerned, beyond quartz phenocrysts. Such volatile-rich magmas would have the ability to fracture the country rocks and set up their own hydrothermal systems. The youngest representatives of the 'Late Dykes' (see previous section) are quartz normative (Brooks \& Platt 1975) and may be equivalents to the quartz porphyries of the Flammefjeld system (as noted previously). An oxygen isotopic investigation of Flammefjeld is overdue. Similar dykes are present at Malmbjerg (author's observation) and this deposit may have a similar origin.

In an early attempt to characterise these deposits, lead isotopes were investigated by Coomer et al. (1974) with a view to aid the exploration efforts of the Nordisk Mineselskab A/S. More recently, Jensen (1998) continued this work, concluding that the deposits were mixtures of metals from the nearby country rocks. Thus, at Kangerlussuaq, Palaeogene lead of distinct North Atlantic character has mixed with primitive lead derived from the surrounding gneisses. North of Scoresby Sund, however, the lead isotope composition of igneous-related deposits shows that they were derived by mixture with Proterozoic and Caledonian sources. While the stratabound deposits of Wegener Halvø are thought to be of Palaeogene age, the lead has been derived from the thick, Palaeozoic-Mesozoic sedimentary rocks of the Jameson Land basin. Jensen's work also included an extended discussion of the lead systematics of the igneous rocks themselves.

It should be noted that there is little evidence that the Skaergaard intrusion's precious metal deposit (or those in nearby gabbros) is hydrothermal. Although its precise genesis is unknown, most workers favour a purely orthomagmatic origin (Bird et al. 1991; Andersen et al. 1997; Nielsen et al. 2005).

\section{Geomorphology}

The first impression one gets of East Greenland is its mountains, which stretch along almost the whole length of the coastline and attain heights of almost 4 $\mathrm{km}$. What is the origin of this mountainous terrain and how long has it been elevated? The author (Brooks 1979, 1985a) studied the topography of the Kangerlussuaq area in some detail and offered explanations for the observations.

Although geomorphology is generally given scant attention by hard-rock geologists, it can make a considerable contribution; not only regarding the contrasting erosion of different rock types and the development of landscapes, but also to changing elevations, which may reveal more fundamental processes taking place in the crust or mantle beneath (e.g. Clift et al. 1998). This idea has recently gained much more appreciation and, for example, previous uplift by the supposed Icelandic mantle plume has been documented in buried landscapes west of the Shetland Islands (Lovell 2010; Hartley et al. 2011). The striking topography of East Greenland is clearly related to the large-scale effects of continental break-up and is probably affected by the impingement of the postulated plume at the base of 

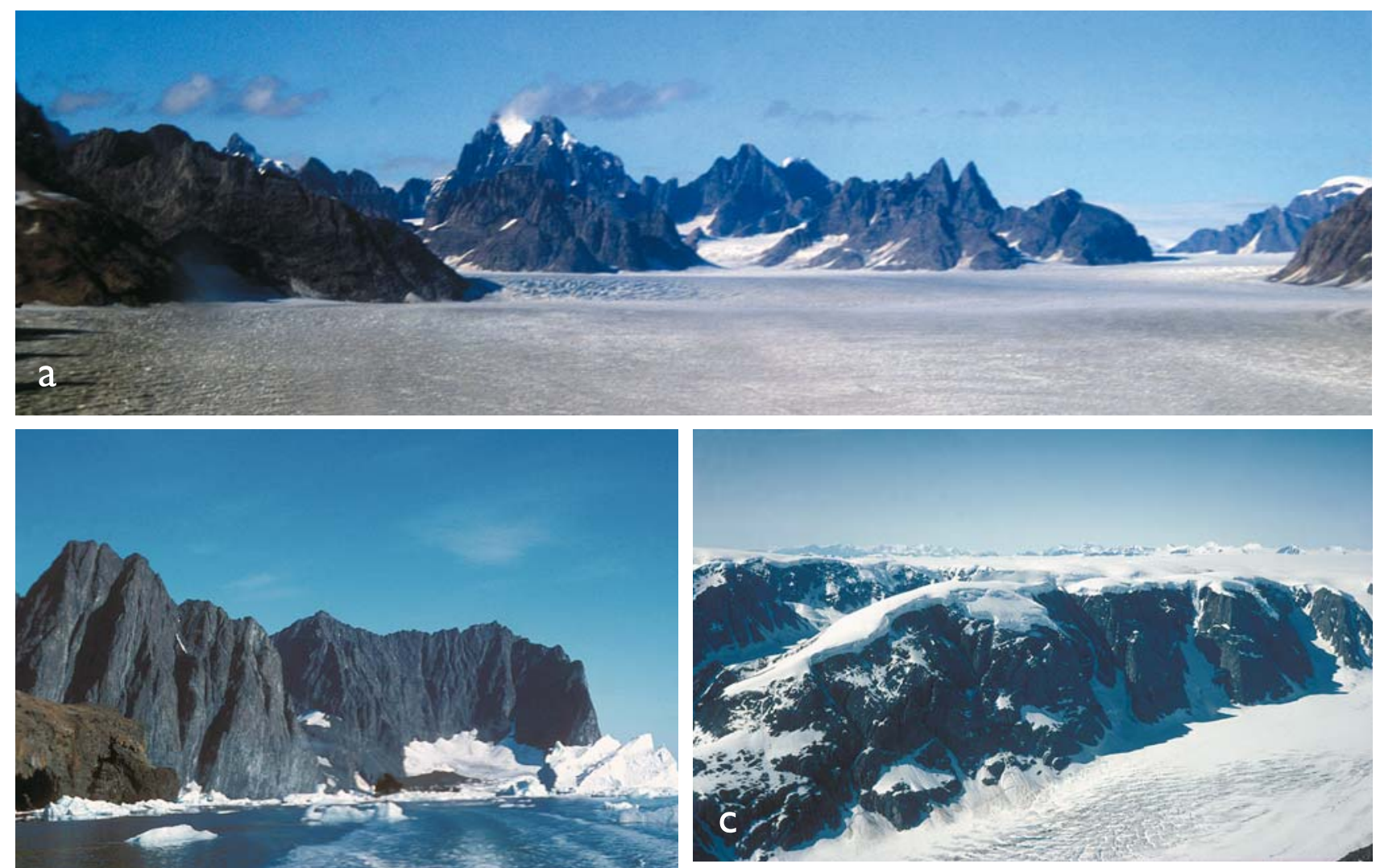

b
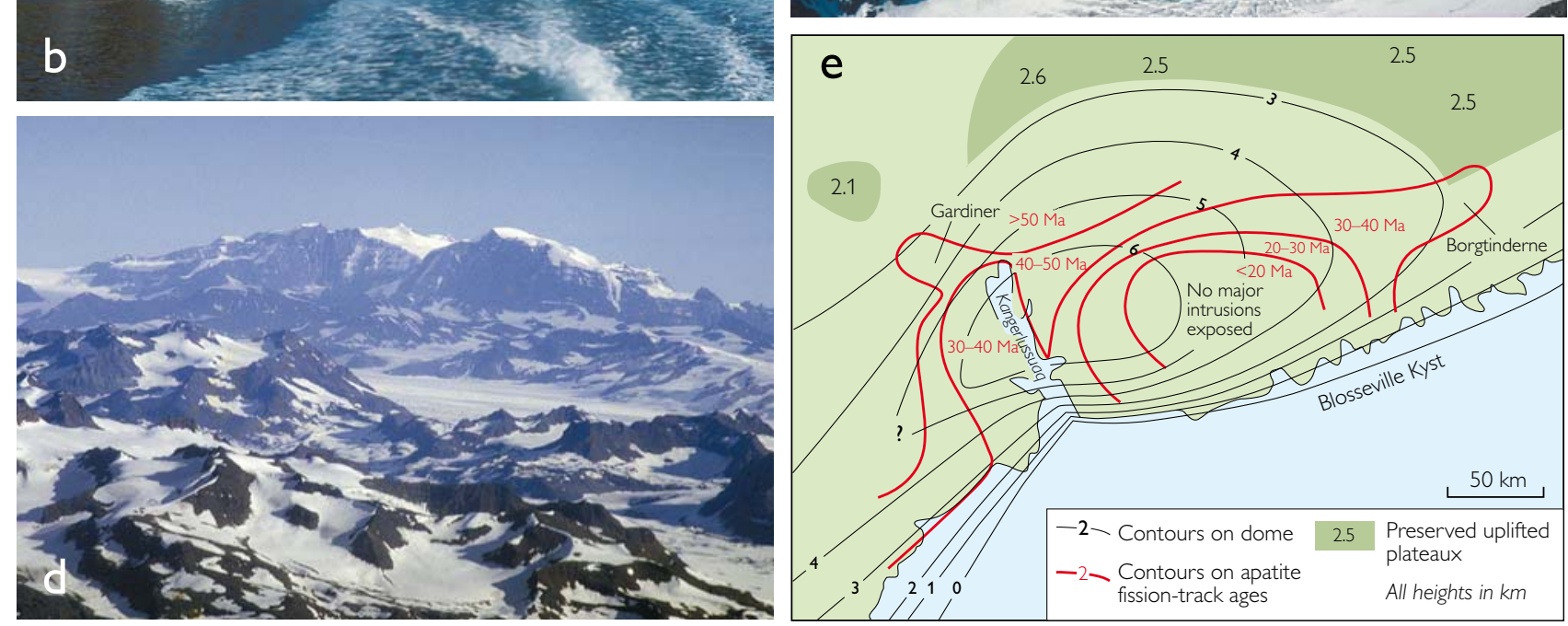

Fig. 22. Geomorphological features. a: The Lemon Bjerge seen from the foot of Frederiksberg Gletscher. The $c .2700 \mathrm{~m}$ high summits of these mountains reach almost to the original gneiss-basalt unconformity and trace the outline of the Kangerlussuaq dome. b: Coast near Miki Fjord. The basalts along the southern part of the Blosseville Kyst have been deeply buried and intensely intruded by dykes and have lost the typical trap topography prevalent elsewhere and seen in Fig. 6a. c: Exhumed pre-basaltic peneplain just north-east of the head of Kangerlussuaq and north of Lemon Bjerge, representing the core of the Kangerdlugssuaq dome. Nordfjord Gletscher in the foreground, Watkins Bjerge in the distance. d: Escarpment of the Watkins Bjerge $(c .3700 \mathrm{~m})$, representing the eroded edge of the updomed basaltic cover. e: The Kangerlussuaq dome (for method of reconstruction see Brooks 1979). Numbers on black contours show the estimated height of the original basalt surface in kilometres. Numbers in inland areas give the height of preserved, uplifted peneplains. Red curves show the distribution of apatite fission track ages (Hansen \& Brooks 2002) revealing a domed area of enhanced heat-flow, somewhat offset from the physical domal structure. 
the lithosphere. There are thus two superimposed effects which must be considered: one causing horizontal movement (continental break-up), the other largely responsible for the vertical movement (epeirogenesis). It should be recalled that Iceland is not only regarded as a classical hotspot or plume site, but is also centred on a spreading ridge that is anomalously elevated (Vogt 1974). A better understanding of the origins of the East Greenland topography is expected to provide valuable clues relating to the formation of passive margins. A major stumbling block is, however, that geomorphological processes, particularly uplift events and the formation of peneplanes, have been difficult to date. Thus, if the crustal uplift was at a markedly different time from the plume activity, we would need to reject the plume hypothesis for uplift. The raised surfaces could not generally be dated prior to the advent of fission-track dating. Increased elevations can often be dated by the timing of sediments shed into adjacent basins, but these have not been explored in East Greenland.

Whilst little work has been published on the geomorphology of the area north of Scoresby Sund since the pioneering work of Ahlmann (1941), the geomorphology of the Kangerlussuaq area was addressed by the author (Brooks 1979, 1985a), who found that this area is characterised by three distinct domains (Fig. 22): the coastal flexure, the inland plateaux (increasingly dissected and descending towards the coast) and a major domal structure centred on the gneissic mountains, Lemon Bjerge, which culminates in Domkirkebjerget (Fig. 12) inland from the Skaergaard intrusion. To these must be added the additional features in the basalt area nearer to Scoresby Sund, referred to above (Pedersen et al. 1997), namely a local point-source uplift possibly indicating an underlying pluton, a half-graben with the Igtertivâ lavas and a structurally complex zone paralleling the coast.

Traditionally, a great drawback to geomorphological studies has been the difficulty of dating typical landscape features, as noted above. The introduction of fission track and $(\mathrm{U}+\mathrm{Th}) / \mathrm{He}$ dating in the last $c .40$ years has given rise to an increasing number of studies, although interpretation is often not straightforward. It is important to note that these methods are not generally aimed at finding the formation age of a rock, but are designed to reveal its thermal history, which, in turn, tells us something of the burial and uplift history of the sample. Fission-track ages may nevertheless reflect the crystallisation age of a rock if cooling was rapid (e.g. for a magmatic rock, its crystallisation age), albeit with lower precision than with other methods. Ages are derived from the density of fission tracks combined with the concentration of $U$, but as the tracks spontaneously shorten over time, depending on the ambient temperature, track lengths must be taken into account to understand the thermal history, and this usually involves numerical modelling.

The many pitfalls inherent in the interpretation of such data have been described by Redfield (2010) using publications from West Greenland as an example. This work is very relevant to the discussion of the East Greenland uplift history as the two areas show many features in common and detailed work on East Greenland is not yet available. Redfield (2010) denied that the case for Neogene uplift can be sustained by the available data, but Redfield's criticisms were robustly refuted by Green et al. (2011). They emphasise that their results show the following events: Paleocene subsidence, Eocene-Oligocene uplift (36-30 Ma), further uplift at $c .10 \mathrm{Ma}$ and final uplift in the Pliocene (7-2 Ma), and that these conclusions are backed up by consistent geological, vitrinite reflectance and apatite fission-track studies. Green et al. (2011) made the important observations (also made previously by Brooks 1979) that the later events are not directly related to continental break-up and that mechanisms to explain them are lacking.

An early application of fission-track studies in East Greenland was that of Brooks \& Gleadow (1977) to derive an age for the Skaergaard intrusion, obtaining $54.6 \pm 1.7 \mathrm{Ma}$ for zircon. Disregarding the large error, the result is essentially identical to more precise ages obtained with U-Pb methods by Hirschmann et al. (1997), Hamilton \& Brooks (2004) and Wotzlaw et al. (2011). Apatite U-Pb data from the same sample as the zircon gave $38.1 \pm 3.1 \mathrm{Ma}$. This indicates that there was protracted cooling, reflecting uplift and erosion of the overlying basalts over $c .20 \mathrm{Ma}$. A later comprehensive study by Gleadow \& Brooks (1979) on a regional basis established that this late cooling took place within the domal structure described by Brooks (1979; see Fig. 22) and probably represents a combination of high heat flow and subsequent unroofing. Nevle et al. (1994) used these observations to postulate Palaeogene climate change in the area, explaining oxygen isotope values in hydrothermal fluids as arising from drainage of waters with falling $\delta \mathrm{D}$ from increasingly higher altitudes as the dome rose from $c .55$ to $c .50 \mathrm{Ma}$.

Gleadow \& Brooks (1979) interpreted their results in the sense that the regional plateau uplift had oc- 
curred at $c .35 \mathrm{Ma}$, coincident with the intrusion ages at Kialeeq, but whether this correlation is meaningful remains obscure as there are very few intrusions of this age at Kangerlussuaq. Gleadow \& Brooks (1979) also extended their study to the Caledonian region to the north showing protracted cooling due to slow denudation of the mountain range. They also dated some of the Mesters Vig intrusions, finding that they were emplaced over a large time span, extending to unexpectedly young ages $(<30 \mathrm{Ma})$ and cooled rapidly, as would be expected for such shallow-level, indeed subvolcanic, complexes. Ages of down to $25 \mathrm{Ma}$ were later confirmed by more precise methods (e.g. Re-Os by Brooks et al. 2004)

There have subsequently been a number of fissiontrack reports: Hansen (1992, 1996, 2000), Clift et al. (1998), Thomson et al. (1999), Mathiesen et al. (2000), Hansen et al. (2001), Hansen \& Brooks (2002) and Hansen \& Reiners (2006). The last of these studies includes $(\mathrm{U}+\mathrm{Th}) / \mathrm{He}$ data which showed discrepancies relative to apatite fission track results. The geomorphology gives irrefutable evidence that post break-up uplift has occurred, but as to the precise timing the controversy between Redfield (2010) and Green et al. (2011) in West Greenland is instructive. It is now generally agreed that significant uplift occurred at least as late as the Miocene in broad areas, which makes it unlikely that uplift was caused by underplating as the supposed plume was remote at this late stage (Clift et al. 1998). Hansen \& Brooks (2002) found an interesting pattern of ages centred inland from Nansen Fjord and, rather surprisingly, somewhat offset from the dome reconstructed by Brooks (1979) based on geomorphological considerations (Fig. 22). This is an area where cooling has taken place very late but it does not obviously correlate with any other geological event in the area the Sorgenfri Sill complex is much older (Tegner et al. 1998b). Perhaps the syenite sills in this area are relevant as they may indicate an underlying, blind pluton, but their dates (quoted in the section on felsic intrusions above) show that these are also too old.

Fission-track dating has shown that inland areas have been quiescent since the Mesozoic and no trace was found of a plume passage heading inland from the head of Kangerlussuaq fjord (Hansen 1996) as might have been predicted from existing models.

North of Scoresby Sund, the country was divided into crustal blocks which behaved independently of one another, giving the present relief dominated by halfgrabens. Much of the development of this area can be deduced from the Mesozoic stratigraphy (e.g. Surlyk 1990). Net uplift since the Carboniferous has been $c$. $9 \mathrm{~km}$ for the Stauning Alper, also a site of domal uplift (Ahlmann 1941), and, in contrast to the situation farther south, cooling has been rapid, but complicated, from c. $55 \mathrm{Ma}$ ago (Thomson et al. 1999).

It seems that fission-track and $(\mathrm{U}+\mathrm{Th}) / \mathrm{He}$ analyses will lead to valuable insights into the development of the landscape, but at present such studies are too sporadic and disconnected to develop a comprehensive picture. Moreover, there are still disputes regarding interpretation. Perhaps the most significant result to date is that the general uplift of East Greenland and probably other areas of the North Atlantic Igneous Province, which is one of its distinguishing features and part of Vogt's (1974) 'Icelandic Phenomenon', is the recognition that the uplift has been relatively recent. However, this conclusion is by no means certain. Future aims will be to better constrain the timing of the uplift and, if possible, identify its mechanism. Such a study is being undertaken at present (P. Japsen, personal communication 2010).

\section{Structure of the East Greenland margin and its setting within the North Atlantic region}

In this section the general structure of the East Greenland margin and how it relates to ocean floor initiation will be summarised and discussed. In many ways it will be a summing up of what has already been said, but it is also an attempt to put East Greenland within a broader setting. The nature of volcanic margins worldwide, with some examples from East Greenland, has been discussed by Geoffroy (2005); this paper gives an overview of contemporary thinking about such margins.

\section{The coastal flexure and its dykes}

In summary, the structure of the East Greenland margin is dominated by the coastal dyke swarm and associated flexure first described by Wager \& Deer in 1938 and later discussed by Nielsen $(1975,1978)$, Myers (1980), Nielsen \& Brooks (1981), Karson \& Brooks (1999), Klausen \& Larsen (2002) and Klausen (2006) 
- see also Rucklidge et al. (1980) for a description of the dyke swarms at Tuttilik in the southern part of the area.

Cataclastic deformation and generation of pseudotachylite (Karson et al. 1998) represent the early stage of crustal extension. The flexure and its dyke swarm must have come much later after extrusion of the main part of the basalts as all the basalts and dykes appear to be tilted to the same extent. The flexure is not a simple bending as perhaps envisaged by Wager \& Deer (1938), as the uppermost lithosphere is too brittle; it actually consists of a multitude of normal faults, including preflexure faults (which may be ancient, reactivated faults, Klausen \& Larsen 2002), syn-flexure faults and postflexure faults (Nielsen 1975, Nielsen \& Brooks 1981), some of which are related to other events. It is clear that the development of the flexure and intrusion of the dyke swarms took place in association with the collapse of the continental margin into the newly formed rift and were accompanied by the growth of the offshore seaward-dipping wedge of lavas (e.g. Larsen, H.C. \& Saunders 1998). A very similar flexure is found on the West Greenland margin (Geoffroy et al. 1998, 1999, 2001a, b) and has been imaged on the Jan Mayen Plateau, which is the continuation of the East Greenland dyke swarm rifted off in the Eocene (Gudlaugsson et al. 1988). It can readily be calculated that extension along these faults accounts for at least as much dilation as that caused by the dykes (Nielsen \& Brooks 1981). It should be noted that the work by Geoffroy et al. (1998, 1999, 2001a, b) has come under scrutiny by Chalmers et al. (2001) on the basis of their own studies in the area (Chalmers et al. 1999a).

The coastal dyke swarm has a total volume of magma that could be at least as large as that of the original overlying lavas, although it is difficult to make an accurate estimate when the dyke swarm is unknown in depth. We can gain a rough idea by calculating the integrated volume in the upper $20 \mathrm{~km}$ of crust, which is very conservative, but nevertheless gives volumes similar to the volume of the basalts (Rucklidge et al. 1980). In addition, there is magmatic material underplated at depth, as discussed below.

The dyke swarm may have formed over a significant period of time, and the impression from existing evidence is that the magmas were emplaced relatively quickly (Neuhoff et al. 1997), although this cannot at present be accurately quantified. An indication of the time span involved might be obtained by a comparison of the coastal dykes cutting and cut by the Skaergaard intrusion, whose age and cooling history are accurately known. Superficially, the number cutting the intrusion is relatively small, but a quantitative study would be necessary as the Skaergaard intrusion is placed somewhat outside the main zone of coastal dyking. Early dykes, which have a composition and age indicating they were feeders to the overlying lavas, including the Lower Basalts (e.g. Gill et al. 1988; Hanghøj et al. 2003; Lenoir et al. 2003; Tegner et al. 2008), have been strongly tilted as shown by equivalent tilting in lavas as well as in sedimentary rocks where these occur. The early tilted dykes are cut by later swarms, which finally become vertical and have different and often more evolved compositions (e.g. Hanghøj et al. 2003). It is clear that the latest dykes, intruded after formation of the coastal flexure, remain close to vertical. The late dykes constrain the length of time of flexuring to only a few million years, and Lenoir et al. (2003, who also estimated a strain rate for this region) determined the duration to be c. $2.9 \mathrm{Ma}$ by ${ }^{40} \mathrm{Ar} /{ }^{39} \mathrm{Ar}$ dating of dykes at Kap Wandel and Kap Gustav Holm. As previously noted inland dykes are sporadic, but, from the hinge line of the flexure, dyke abundance increases rapidly seawards and may reach $>95 \%$ of the outcrop area in some areas, being effectively a sheeted dyke swarm. The coastal swarm is here similar to the sheeted dykes of ophiolites, such as the Troodos massif on Cyprus, and such dyke complexes are thought to make up Layer 2 of the oceanic crust. Just as in the sheeted dyke swarms, the East Greenland dyke swarm, where it is densest, hardly has any screens of country rock. Furthermore, dykes have intruded one into another leaving one-sided chilled margins, as described by Kidd \& Cann (1974). The offshore extension of this dyke swarm is unknown although it has been discussed by Larsen, H.C. (1978).

\section{Segmentation of the margin}

A notable feature of the margin is its segmentation, with en échelon segments filled from central magma chambers (Myers 1980; Karson \& Brooks 1999; Klausen \& Larsen 2002; Callot et al. 2001, 2002). The segmentation occurs on several scales. A first-order segmentation is represented by the Kangerlussuaq triple junction and the triple junction to the south of Greenland where the Reykjanes, Mid-Atlantic and Labrador Sea Ridges meet (Nielsen, T.K. et al. 2002). Second- and third-order segmentation is marked by largely strike-slip faulting at a high angle to the dyke swarms, although vertical 
offsets are apparently important in some cases. Secondorder segmentation may equate with the geophysical regions described by Larsen, H.C. (1990, see Fig. 19), distinguished on the grounds of morphology, differences of crustal type, subsidence history, etc. These units are spaced $c$. 100-120 km. The third-order accommodation zones are spaced $c .25-39 \mathrm{~km}$ apart and are usually marked by abrupt changes in dyke intensity, fault geometries and flexure geometries. Spacing of the gabbro intrusions may be related to this segmentation, while the possibility of nephelinite-carbonatite volcanism, suggested in the previous section on nephelinites and carbonatites, may have been controlled by the secondorder accommodation zones (Fig. 19). Guarnieri (2011) described two periods of strike-slip faulting separated by the formation of the coastal dyke swarm in Sødalen, although the significance to the overall tectonics of the margin was unclear. However, it was suggested that the third phase of faulting was connected to the regional uplift.

\section{Vertical and horizontal distribution of igneous material in the crust}

As already noted, the igneous rocks at the surface are only a small part of the total amounts of magma involved. An important part of the magma budget is underplating of magma beneath the margin. Such a process has been argued by Brooks (1985a) and Cox (1993) as being responsible for the high elevations of such regions, although it does not explain the late timing of the uplift (see the geomorphology section). The margin was imaged in some detail by the SIGMA project (see e.g. Korenaga et al. 2000, 2002; Holbrook et al. 2001; Hopper et al. 2003), which showed thick wedges of high velocity material under the margins that was interpreted as underplated basaltic material. The wedges were found to decrease with distance to the south as did the thickness of ocean crust from $c .30$ to $c .17$ $\mathrm{km}$ (for location of profiles see Fig. 1). This decrease is taken to reflect waning magma production away from the Icelandic hotspot and corresponding decreasing amounts of underplated material. Note, however, that White et al. (2008) claimed that the magmatic material was emplaced largely as sills rather than by underplating, and in East Greenland the dyke swarms represent a volume of a similar order of magnitude as the lavas, as discussed previously. Holbrook et al. (2001) further estimated that the ratio of intruded to extruded magma is $1.5: 1$, which broadly corresponds to this author's estimates as it includes the underplated material and is therefore $50 \%$ higher.

Across the continent-ocean transition, the thickness of the crust diminishes from $c .30$ to $c .8 \mathrm{~km}$, which was explained e.g. by Holbrook et al. (2001) as a result of vigorous active upwelling during the early stages, giving way to passive upwelling later. The transition from Archaean crust to true oceanic crust takes place over c. $400 \mathrm{~km}$ (Korenaga et al. 2000; Hopper et al. 2003).

Summarising these results, we see that large amounts of igneous material crystallised at the base of and within the crust. Also, the amount of igneous material decreases both laterally away from the presumed hotspot and temporally after initial break-up. In particular, decreasing melt volumes, both with distance from the centre and with distance from the initial break-up site, are consistent with the idea of a plume consisting of a large head and a thin tail (e.g. Campbell 2007).

Generation of copious amounts of magma by a plume requires that the plume has excess temperature, suggested to be $c .300^{\circ} \mathrm{C}$, relative to that at mid-ocean ridges, where extension as the plates move apart causes passive melting by simple decompression in the mantle (e.g. Klein \& Langmuir 1987). Note that these values are expressed as 'potential temperature', that is, the equivalent temperature of the magma at depth when adiabatically decompressed to surface pressure. Plumes with excess temperature have thermal buoyancy and cause melting by an excess of temperature, known as active melting. Whether plumes show such excess potential temperature is a long-standing controversy and surprisingly difficult to determine to everyone's satisfaction. One of the latest discussions on this subject is that of Herzberg \& Gazel (2009) who showed, using petrological arguments, that many large igneous provinces had potential temperatures (as defined above) of c. $300^{\circ} \mathrm{C}$. According to Herzberg \& Gazel (2009) the North Atlantic province was one of the regions of high potential temperature, but in common with other provinces (e.g. the Caribbean large igneous province with its present manifestation at Galapagos), the temperature decreased with time to a present excess potential temperature of $c .100^{\circ} \mathrm{C}$ in Iceland. This reinforces the long-held assertion that plume heads are the sites of most voluminous magmatism (e.g. Campbell \& Griffiths 1990). In a modelling study of the Ocean Drilling Program Legs 152 and 163 (Fig. 1), an area also covered by the SIGMA project (Holbrook et al. 2001), it was 
shown by Armitage et al. (2008) that the basalt compositions could be reproduced by including a hot layer and with a pulse of rapid extension. No anomalous mantle was required. This scenario is nevertheless broadly consistent with existing requirements of the plume hypothesis (e.g. Campbell \& Griffiths 1990, Campbell 2007) and explains the rapid decrease in igneous production, as measured by crustal thickness, towards the ocean. However, it is also clear that a complete understanding of magma production and continental break-up has still not been acquired.

\section{Plate-tectonic patterns}

Since the formation of the first ocean floor c. $55 \mathrm{Ma}$ ago (magnetochron 24r), spreading appears to have been relatively simple south of present-day Iceland, equivalent to the areas south of Kangerlussuaq in the Paleocene. In this area, the host rocks are Precambrian. To the north, however, spreading was more complex. In the Blosseville Kyst area, Larsen, L.M. \& Watt (1985) showed that abortive early break-up was to the west, probably along the $\mathrm{N}-\mathrm{S}$-trending zone of heavy fracturing and passing into the inner reaches of Scoresby Sund and perhaps farther to the Caledonian main fault, as shown in Figs 2 and 14a. The lower two basalt formations were, at least, partially sourced along this zone. Later, the rift jumped to the east, forming the prominent bulge that is Blosseville Kyst (Larsen, L.M. \& Watt 1985; Larsen, L.M. et al. 1989; Larsen, H.C. 1988). Early spreading also took place along the Ægir Ridge, and extending northwards to the Jan Mayen Fracture Zone, in the area where the lithosphere had been subjected to late Caledonian and Mesozoic rifting events. Later, from the Middle Eocene (chron 20) to the Late Oligocene at $c$. Chron 6-7 (Talwani \& Eldholm 1977; Nunns 1983a, b; Bott 1987; Larsen, H.C. 1988; Eldholm et al. 1990) the spreading axis gradually relocated to the west on the present Kolbeinsey Ridge (Fig. 23a). This led to the splitting off of the Jan Mayen Plateau, previously part of Greenland (Scott $e t$ al. 2005), reducing the bulge in the spreading axis, and with a consequent profound modification of the East Greenland margin in these regions. The northwards continuation of the flexure and its associated dyke swarm is now to be found on the eastern side of the Jan Mayen Plateau and was imaged by Gudlaugsson et al. (1988). It may be that this event led to new mag- matic episodes in East Greenland (as argued by several authors, e.g. Brooks et al. 2004). The balanced extinction and propagation of ridges were first described by Hey et al. (1989) from the East Pacific Rise and applied to the Reykjanes Ridge by Hey et al. (2010).

Vink (1984) showed how the Greenland-IcelandFaroe ridge area and the Vøring Plateau could be explained by a plume, moving relative to the plates, coupled with a transform fault (Jan Mayen) and a ridge jump (Ægir to Kolbeinsey). This once well-received model (Fig. 23b) seems to have become forgotten by workers in the area.

\section{Vertical movements and erosion}

Another intractable problem concerns the topography of the area. This section extends the discussion of the subject introduced in the section on geomorphology, with a more regional view. East Greenland constitutes a mountain range comparable in bulk to collisional mountain belts, such as the European Alps, although East Greenland has not experienced significant compressional tectonics since the Palaeozoic, when the Caledonian mountains were formed and rapidly peneplained. Moreover, East Greenland is not unique. The same anomalous situation is found throughout the North Atlantic Ocean and was called the 'Icelandic Phenomenon' by Vogt (1974). Thus, high margins flank the Atlantic Ocean in eastern Canada, West Greenland, Norway and Scotland; all areas thought to be affected by the Icelandic plume. What are the timing and origin of such uplifts?

Topography, of course, generally reflects the thickness of the lithosphere, except where dynamic effects in the mantle cause anomalies (positive over rising mantle, e.g. plumes, and negative where mantle descends, e.g. over subduction zones). Dynamic uplift has a long wavelength of hundreds to thousands of kilometres and is transient (Braun 2010), so the short-wavelength and apparently relatively stable uplift seen in East Greenland doubtlessly owes its origin to thickened lithosphere. This is most likely caused by gabbroic underplating or major sill emplacement at depth, as mentioned in several places here, and favoured by the results of the SIGMA project (Holbrook et al. 2001). However, as seen already, the timing is difficult to reconcile, as was also pointed out by Clift et al. (1998). 


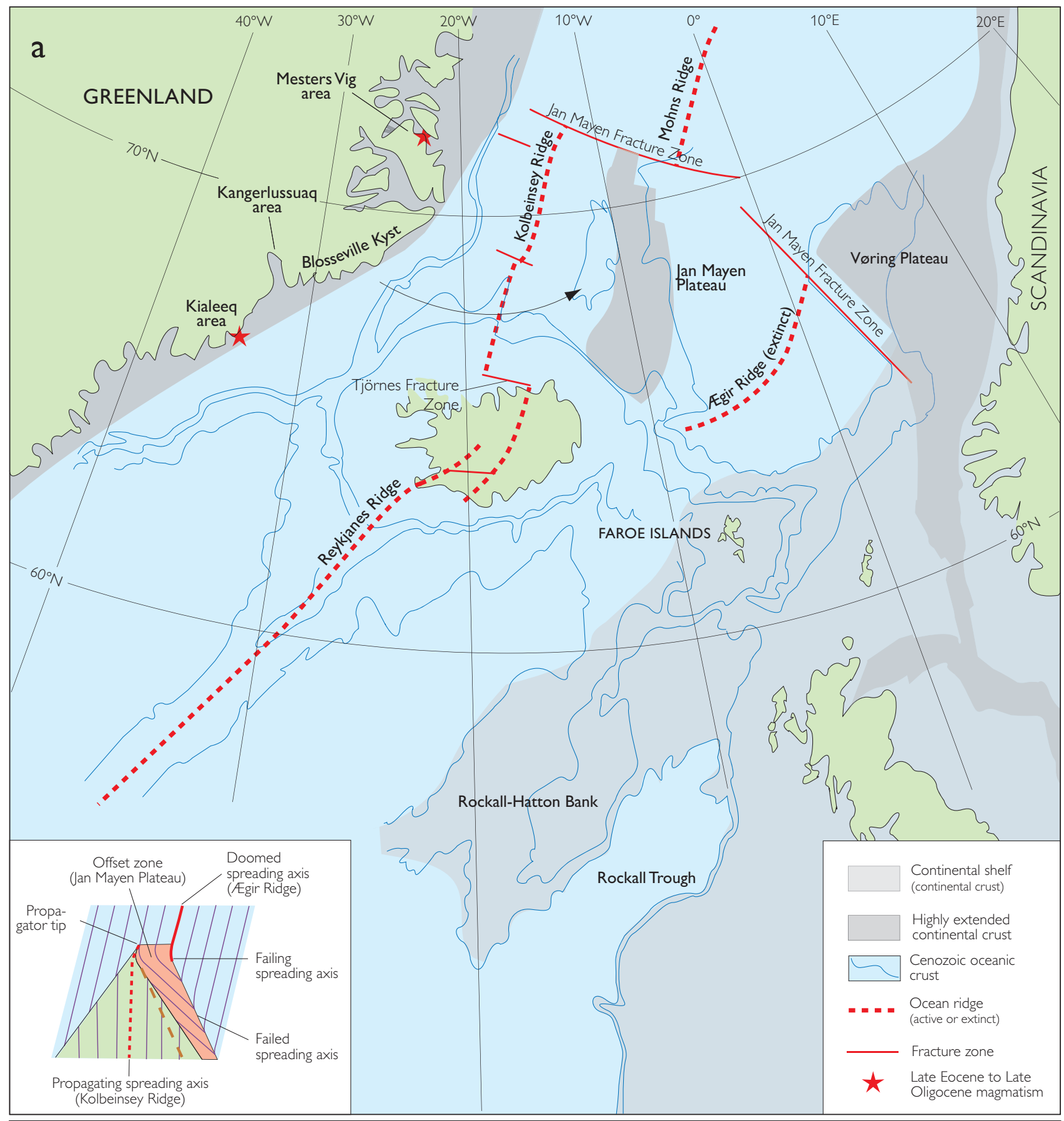

MODEL

b Modified from Vink (1984)

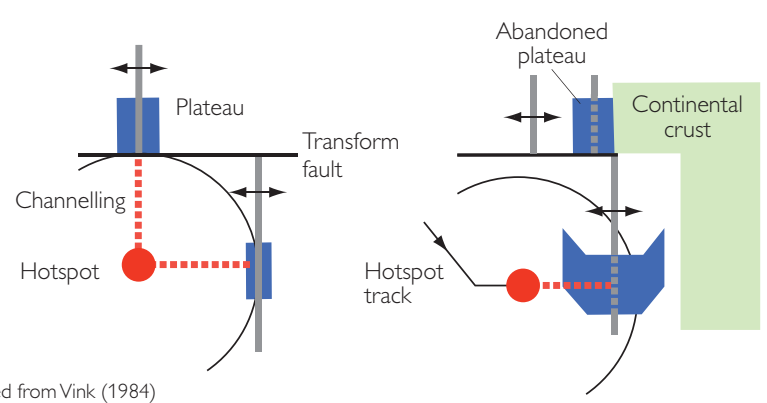

OBSERVED

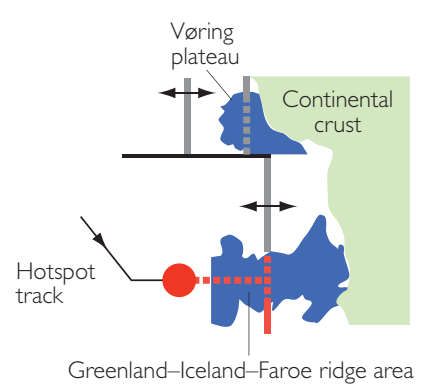


The complicated interplay between several factors (uplift, erosion, climate) has been succinctly covered by England \& Molnar (1990) and Molnar \& England (1990). They argue that many workers have postulated late uplift using proxies that may instead reflect global climate change. In East Greenland, however, the late Cenozoic uplift seems to be well established by fissiontrack studies, although its precise timing has not yet been pinpointed. As noted above, the idea that the uplift was caused by crustal underplating was attractive as it shows no signs of thermal relaxation, but this explanation is unlikely as the uplift was delayed by tens of millions of years (as noted above). Medvedev et al. (2008) argued that the erosion of deep fjords and the transfer of sediments to the shelf were sufficient to account for the uplift of the high peaks, suggesting that the erosion was glacier driven. It remains to be shown that the majority of the uplift can be assigned to the Pleistocene, although undoubtedly some of this uplift can be accounted for in this way, as remarked by Brooks (1979 \& 1985a). Also, the present fjords may represent large pre-Pleistocene alluvial valleys only modified to a relatively minor extent by glacial activity so that uplift had begun at an earlier stage. Rather, it is tempting to view the distribution of high land round the North Atlantic Ocean as being somehow connected to the 'Icelandic anomaly': the sea-floor also being unusually shallow here with Iceland itself as the only place where the mid-Atlantic ridge becomes subaerial. It therefore seems that the mountain uplift in East Greenland (and other areas of the North Atlantic region) critically depends on a consensus to explain Iceland's anomalous topography.

Geomorphological studies (Brooks 1979) have shown that the East Greenland margin was subjected to two main uplift events: the formation of a domal

\section{Facing page:}

Fig. 23. a: Plate-tectonic features of the North Atlantic region. b: The model of Vink (1984) for plume control of North Atlantic oceanic plateaux (redrawn and simplified). Model with two successive stages shown left and application of the model to the right. In its early stages the plume feeds both the Vøring plateau and the Faroe Islands, being at equal distance (marked by arc) from the plume centre. With spreading, the Vøring Plateau becomes too distant due to a change in direction of plate movement, and the plume now only feeds the Greenland-Iceland-Faroe ridge area. structure rising to $c .6 \mathrm{~km}$ above present sea level and centred on the Kangerlussuaq area, and a regional uplift of c. $2 \mathrm{~km}$ giving the high East Greenland coastline. These two topographic features could well have different causes. Fission-track studies (Gleadow \& Brooks 1979; Hansen 1992, 1996, 2000; Hansen \& Brooks 2002; Hansen \& Reiners 2006) show that uplift and erosion took place $c$. $20 \mathrm{Ma}$ after the continental breakup and continued into the Neogene, but precise mechanisms for these events remain obscure, the delay probably being inconsistent with the idea of underplating as suggested by Brooks (1985a), Cox (1993) and White et al. (2008).

One of the arguments relating to uplift are the socalled V-shaped ridges on the Reykjanes Ridge (see Hey et al. 2010 for references to the rather extensive literature). Two recent papers continue the old idea that these ridges are caused by pulses of enhanced magmatism travelling along the ridge axis and causing uplift (Poore et al. 2011; see also White \& Lovell 1997, and Hartley et al. 2011 for a similar explanation for North Sea events). However, Hey et al. (2010) refuted the pulsing plume model and claimed that these diachronous ridges are due to ridge jumps, as was also favoured by Hardarson et al. (1989).

\section{Time frame for magmatism and margin deformation}

High-precision ages for other parts of the North Atlantic Province have gradually appeared (e.g. Berggren $e t$ al. 1995; Pearson et al. 1996; Storey et al. 1998; Hamilton et al. 1998; Gamble et al. 1999; Heister et al. 2001; Chambers et al. 2005) allowing a comparison with the ages summarised here for East Greenland. Although space does not permit a detailed account of the present state of knowledge regarding the geochronology of East Greenland and its relation to the rest of the North Atlantic Igneous Province, Fig. 24 presents a summary of the East Greenland geochronological data, as discussed above. See also the compilation in the Appendix. In this figure, it is important to note that some of the events are major, such as the formation of the Main Basalts at c. $56 \mathrm{Ma}$, and other events, such as the intrusion of late alkaline dykes, are volumetrically quite minor. In general the later events were not voluminous in comparison to the Main Basalts. Figure 24 also includes data on major tectonic adjustments in the North Atlantic area 
and estimates for magma production from Storey et al. (2007b) around the break-up event.

A perusal of Fig. 24 does not reveal any striking patterns. The main activity was with the early plate separation in the Labrador Sea at 62-60 Ma and the subsequent plate separation in the North-East Atlantic around C24r or 57-55 Ma. These two events clearly relate to the extrusion of the Lower Basalts and the Main Basalts. After this, intrusive activity continued, most notably in the Kangerlussuaq area, with much later activity around Kialeeq to the south (Fig. 17) and Mesters Vig to the north (Fig. 14), which corresponds to late minor activity in West Greenland. As discussed previously, this may be related to rifting of the Jan Mayen Plateau and subsequent cessation of spreading on the Ægir Ridge, although clear synchronicity is not obvious. The cause of the latest Miocene activity at Vindtoppen is also obscure, although Storey et al. (2004) concluded that this was due to partial melting of metasomatised mantle, perhaps triggered by an uplift event that seems to have occurred at this time (i.e. 13-14 Ma). The intrusions at Kialeeq seem to correlate with major plate-tectonic adjustments as suggested in Fig. 23.

Of particular interest here, is the sanidine-bearing tuff whose temporal position is shown in Fig. 3. As previously mentioned, this tuff is thought to be identifiable over a wide North Atlantic area, both in the ash layers in northern Denmark, in those of the North Sea, in eastern England and in DSDP Hole 550, $14^{\circ} 14^{\prime} \mathrm{W}$, $48^{\circ} 25^{\prime} \mathrm{N}$, south-west of Ireland, although Heister et al. (2001) and Larsen, L.M. et al. (2003) do not concur on its source being necessarily the Gardiner complex. Related ash layers, perhaps some of the largest on record, even extend to Austria. Such layers are therefore important time markers, especially as in Hole 550 it was deposited shortly after the Paleocene-Eocene Thermal Maximum, a subject that has been under intense debate in recent years and the cause of which is still not well understood. One previously mentioned hypothesis is that of Svensen et al. $(2004,2010)$, who argued that the required amounts of methane were generated by sill intrusion into carbonaceous sedimentary rocks in the North Atlantic Igneous Province. This is appealing as the timing is correct. The age of the PaleoceneEocene Thermal Maximum has recently been greatly improved, first by the work of Westerhold et al. (2007, 2009). ${ }^{40} \mathrm{Ar} /{ }^{39} \mathrm{Ar}$ dates on the sanidine are many, but calibration uncertainties in the ${ }^{40} \mathrm{Ar} /{ }^{39} \mathrm{Ar}$ method mean there is a relatively large uncertainty in the results. Probably the best estimate to date is a $\mathrm{U} / \mathrm{Pb}$ age on zircon from a section on Spitsbergen (Svalbard archipelago, Fig. 1) giving $55.785 \pm 0.034 \mathrm{Ma}$ (Charles et al. 2011). An attempt should be made to date the perovskites that occur in the ashes of the Fur Formation of Denmark. This, combined with astronomical tuning of the sedimentary rocks, is of great importance, not only for correlations throughout the North Atlantic region, but also for calibration of the geological time scale and our understanding of important environmental events such as the Paleocene-Eocene Thermal Maximum.

\section{Mechanisms of North Atlantic rifting}

Another important question, touched on previously, is the apparent asymmetry of the North Atlantic and Norwegian-Greenland seas. Asymmetric features include: generally higher topography on the Greenland side (indeed the Rockall-Hatton Bank and Vøring Plateau are submerged), larger volumes of igneous rocks (according to Hopper et al. 2003, nearly twice the amount on the Greenland side), different magmatic compositions (syenites and nephelinites are rare on the European side and carbonatites have not been report-

\section{Facing page:}

Fig. 24. Summary of the geochronology of the North Atlantic Igneous Province. Timings shown are based on a compilation of ages deemed to be the most reliable: ${ }^{40} \mathrm{Ar} /{ }^{39} \mathrm{Ar}$ ages that fulfil accepted criteria, U-Pb ages and occasional Re-Os ages (see also Appendix). Plate-tectonic events shown on the left are based on references in the main text. Magma productivity around the time of break-up from Storey et al. (2007b). Time scale from Gradstein $e t$ al. (2005). Data sources: British Hebridean Province: Archer et al. (2005), Chambers \& Fitton (2000), Chambers \& Pringle (1999, 2001), Chambers et al. (2005), Gamble et al. (1999), Gibson et al. (1995), Hamilton et al. (1998, 1999), Hansen, D.M. (2006), Pearson et al. (1996), Troll et al. (2008). Faroe Islands: Storey et al. (2007b). East Greenland south of Scoresby Sund and offshore: Hamilton \& Brooks (2004), Hansen et al. (2002), Gleadow \& Brooks (1979), Heister et al. (2001), Peate, D.W. et al. (2003), Sinton \& Duncan (1998), Storey et al. (2004, 2007b), Tegner \& Duncan (1999), Tegner et al. (1998b, 2008), Wotzlau et al. (2011). East Greenland north of Scoresby Sund: Brooks et al. (1979, 2004), Price et al. (1992), Rex et al. (1979), Upton et al. (1995) and unpublished data by C. Tegner and C.K. Brooks from the Mesters Vig area. West Greenland: Storey et al. (1998). 


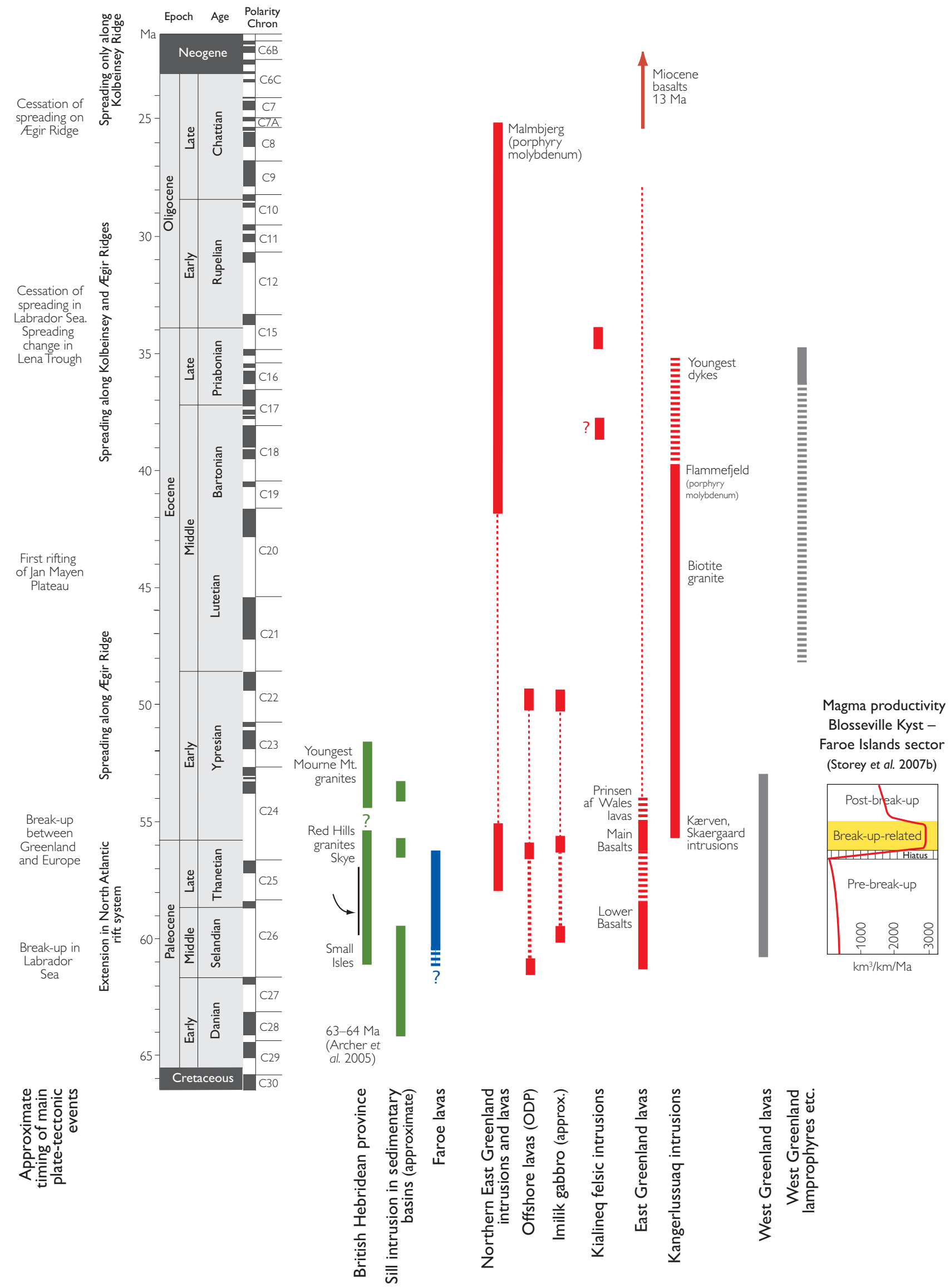


ed) and a much longer period of igneous activity in East Greenland. The asymmetry has important bearings on the mechanism of break-up, the loci of magmatic activity and the shapes of sedimentary basins. It is also a deeply controversial subject. Continental break-up is usually depicted as simple ductile necking (pure shear) of the lithosphere. However, Rosendahl (1987) showed the asymmetry of the African rift basins, typically half-grabens, suggesting that rifting takes place by detachment (simple shear), an idea applied to many rifts worldwide by a range of authors. For example, Wernicke \& Tilke (1989) used this model for the central Atlantic margin of the United States and pointed out that the Woodlark Basin rift of Papua New Guinea advances by a series of rift basins forming along low angle detachment faults (Speckbacher et al. 2011 and references therein). The simple shear model has been particularly popular with Norwegian geologists, explaining their own margin, where, it should be remembered, large amounts of observational material have been gathered in the search for hydrocarbons.

Torske \& Presvik (1991) attributed the nephelinites of the Vestbronna Formation on the Møre platform (Fig. 1) to simple shear, while Mosar et al. (2002a) regarded the Norwegian margin as defined by low-angle detachment faults, which change their polarity across the Jan Mayen Fracture Zone. The Møre margin is thus a lower- plate margin, and the Vøring-Trøndelag margin an upper-plate configuration. Consequently, the central fjord district of East Greenland including the basalt plateaux would be lower-plate, while the Liverpool Land margin would be upper-plate. To extend this southwards, the margin from Scoresby Sund to Kangerlussuaq would again be lower-plate and south of this upper-plate. Could this explain some of the geological observations discussed in this paper; for example the distribution and preservation of the basalt plateaux? Certainly, the postulated changing polarities appear to take place along some of the accommodation zones described by Karson $\&$ Brooks (1999) or along changes of crustal character found by Larsen, H.C. (1990), as shown in Fig. 19.

On the other hand, it is worthwhile noting that studies of the East Pacific Rise have shown that it too is asymmetric (Melt Seismic Team 1998; Levi 1998), although there is no suggestion that simple shear is the controlling mechanism here. Rather it is caused by westward drift of the underlying upwelling mantle. Nevertheless, Hinz et al. (1987) stressed the symmetry of the Norwegian and East Greenland margins. However, the object of their studies was primarily the seaward-dipping reflectors, which may disguise an earlier asymmetry, and more recent work favours an asymmetric structure (Hopper et al. 2003).

East Greenland, this phase is represented by the Lower Basalts at Kangerlussuaq, which are more picritic, more contaminated and more explosive than the succeeding Main Basalts. The most voluminous burst of volcanic activity was at c. 56-55 $\mathrm{Ma}$ and occurred in East Greenland, represented by the Main Basalts which cover $c .65000 \mathrm{~km}^{2}$ and have a thickness $>7 \mathrm{~km}$.

(2) After c. $55 \mathrm{Ma}$, major extrusive activity in East Greenland had ceased. However, activity continued in the Mesters Vig area until c. $25 \mathrm{Ma}$, and extensive felsic activity occurred in the Kialeeq area at $c .35 \mathrm{Ma}$ (Fig. 16). Similarly, minor activity 
occurred sporadically in West Greenland until at $c$. $30 \mathrm{Ma}$ (Storey et al. 1998). Further, renewed basaltic volcanism is recorded in the Miocene Vindtoppen Formation (c. $14 \mathrm{Ma}$, Storey et al. 2004), and up to the present time at Jan Mayen (Trønnes et al. 1999), the Vesteris bank (Haase \& Devey 1994) and the Icelandic flank volcanoes such as Snæfellsjökull.

(3) Volcanism continues today in Iceland and can be regarded as a direct extension of the events occurring in East Greenland in the Palaeogene. The postulated mantle plume is now supposed to be situated under Vatnajökull (Wolfe et al. 1997). The main difference from East Greenland is that continental crust is currently not thought to be present in Iceland. This probably accounts for much of the contrast between Palaeogene Greenlandic volcanism and Recent Icelandic volcanism such as the abundance of syenites in East Greenland and the lack of strongly undersaturated rocks of the nephelinite-melilite clan in Iceland, which may be the result of a thicker lithospheric lid in East Greenland and be caused by the presence of continental crust. Contamination of Icelandic rocks with amphibolite- and granulite-facies gneisses, which is observed in East Greenland, would not be expected and has not been observed in Iceland, although felsic magmas are relatively abundant. It is worth noting that the earliest rifting event discernable in Iceland took place from 25 to $15 \mathrm{Ma}$ ago. Volcanic cycles in Iceland are connected to ridge jumping, which is thought to occur in order to bring the spreading centre over the plume head. The rifting events in Iceland had an approximate life span of 8-12 Ma (exact values are difficult to decipher as there is an overlapping period of propagation and dying: Hardarson et al. 1997; Pringle \& Hardarson 2000). This is similar to the 5-10 Ma clustering of activity in the different areas of East Greenland (Fig. 24). Doubtlessly, these events are closely connected with the plate-tectonic development of the northernmost Atlantic region, although uncertainties in the timing of plate-tectonic events do not at present allow a precise correlation. In Iceland, the clustering seems related to the movement of the plate boundary relative to the plume, with consequent adjustments of the former.
(4) Numerous attempts have been made to relate magmatic activity to the passage of the supposed Icelandic plume. The most widely accepted scenario is as follows. The earliest activity beginning c. $62 \mathrm{Ma}$ ago is thought to reflect the arrival of the plume in the area, although the passage of the plume depends on whether one relies on surface manifestations (Brooks 1973; Forsyth et al. 1986; White \& McKenzie 1989) or models based on palaeomagnetism (Lawver \& Müller 1994), as previously discussed in the introduction to the section on the Main Basalts. Later activity at $55 \mathrm{Ma}$ reflects the first successful break-up between the Faroe Islands and Greenland, while activity in the range $52-47 \mathrm{Ma}$ is thought to mark the passage of the plume stem under East Greenland (Tegner et al. 1998b). The cause of later igneous activity, largely at 35 and $25 \mathrm{Ma}$ in the Kialeeq and Mesters Vig areas, remains obscure, but may be related in part to plate reorganisation in the North Atlantic Ocean, such as the demise of spreading in the Labrador Sea and of the Ægir Ridge, the splitting off of the Jan Mayen Plateau and a change in spreading along the Lena Trough, all taking place around the time of magnetochron $\mathrm{C} 13$, dated at $c .33 \mathrm{Ma}$ (Fig. 24).

The ultimate cause of the formation of the North Atlantic Igneous Province, i.e. plume or non-plume, has been discussed by numerous other authors (see e.g. DePaolo \& Manga 2003; Foulger et al. 2005; Campbell 2007; Foulger 2010) and lengthy further discussion is out of place here. Nevertheless, our understanding of this major geological event, so beautifully displayed in East Greenland, seems to be far from reaching a consensus, either on this subject or others such as the cause and timing of uplift, and brief comments are warranted. The present discussion is confined to a summary of the main features that are believed to be strong evidence for a plume origin as originally suggested (Brooks 1973). These include the rapid eruption of high-temperature magmas over a wide area. Although controversial, most petrologists regard picrites as evidence of high-temperature source regions. Regional uplift of the lithosphere is evidence for the arrival of the temperature anomaly under the area. Extraordinarily large volumes of magma, far in excess of that which can be produced by simple extension, were produced at the height of the break-up. The subsequent decrease in magma volumes was pre- 
dicted in the original exposition of impacting mantle plumes by Campbell \& Griffiths (1990) and recently modelled by Armitage et al. (2008) and Herzberg \& Gazel (2009). The trace of the supposed plume trail in the aseismic Greenland-Iceland-Faroe ridge area (e.g. Wilson 1963; Brooks 1973; Vink 1984; Richards et al. 1989) was noted many years ago. In addition, a decrease in productivity away from the supposed plume centre and orthogonal to the plume trace, as shown by the SIGMA transects (Fig. 1; Holbrook et al. 2001; Hopper et al. 2003). Even the double pulse represented by the Lower Basalts and the Main Basalts may be modelled (Shu-Chuan Lin \& van Keken 2005).

Finally, seismic imaging of the hot plume has been claimed for both Iceland and Hawaii (Wolfe et al. 1997, 2009). Additional evidence for this is provided by the discovery that the West Greenland and Baffin Island lavas (and by extension those of the rest of the province, as well as other likely plume sites worldwide) are derived from regions of primitive mantle. They seem to coincide with regions of anomalous seismic behaviour, known as the large-low-shear-wave-velocity provinces (Torsvik et al. 2010; Jackson \& Carlson 2011).

\section{Concluding remarks}

The East Greenland margin, with its well-exposed and well-documented features, is an incomparable laboratory for the study of the interplay between mantle flow, lithospheric tectonics and the formation of a rich diversity of magmas. It is thus an outstanding test area for the existence of a mantle plume.

In the above, the extreme complexity of the East Greenland margin has been described. It is both typical and better exposed than most comparable places such as Brazil, South Africa or India, not to mention submerged large igneous provinces such as Ontong Java. These complexities have to be taken into account in any comprehensive explanation of continental rifting leading to ocean formation, making a detailed documentation of the magmatic, tectonic and chronological evolution of the margin of paramount importance. However, it must be concluded that not only the fundamental cause of large igneous provinces is still in debate but lesser questions are far from being understood. Many basic processes remain enigmatic - as demonstrated by the Skaergaard intrusion, one of the best studied intrusions in the world, but nevertheless still highly controversial.

During the time this author has worked in East Greenland, a wealth of new observations have been made: new intrusions discovered, tectonic events revealed, refinement of the geochronology, knowledge of the offshore extensions gained and large systematic collections of both samples and data assembled. This makes it clear that observation plays a crucial role and theory must come in second place. Many earlier models have been shown to be inappropriate when new discoveries have been made in the field or new collections have been studied. Additionally many elegant models have been proposed on the flimsiest of evidence. It is obvious that earlier ideas were often based on too little observation and too few samples. This is not necessarily a criticism: it was often not possible to do better, either because of the difficulties of field work or by the limitations imposed by laboratory procedures. Today, with the common availability of STOL aircraft and helicopters, the only barrier to transportation and hence observation is the cost. Furthermore, the great improvements that have come about in analytical and geochronological methodology; in accuracy, precision, speed and scope have already shown results. Of all improvements, micro-beam methods may be the most significant as they allow single-gain dating of minerals with high precision as well as detailed study of minerals with a view to tracking the history of magmatic development. Similar advances in seismic methods and in the interpretation of fission-track data have also been made. Although the North Atlantic Igneous Province, especially the Hebridean part, is probably the most thoroughly researched province of its type, many important details still continue to emerge. Not least, the detailed geology of the offshore areas is still only known in outline, although much information is emerging from the oil and gas industry west of the Shetland Islands. Until we come close to a precise knowledge of what all parts of the province contain and how the province developed, sophisticated models relating the magmatism to plate-tectonic events and plume properties will remain ill-founded. 


\section{Acknowledgements}

Professors L.R. Wager and W.A. Deer introduced me to East Greenland in my student days and inspired me with the mysteries of igneous rocks and their minerals. I would like to thank my students and colleagues who contributed to the Kangerlussuaq Project, in particular: Jens-Christian Andersen, Stefan Bernstein, Karen Hanghøj, Rune Larsen, Peter Momme, Troels F.D. Nielsen, Morten Riishuus and Christian Tegner. Dennis K. Bird has repeatedly provided invaluable scientific input. Our research was financed by Statens Naturvidenskabelige Forskningsråd (Danish Natural Science Research Council) over many years and supported in the later years by Robert Gannicott, Platinova Resources Limited / Harry Winston Diamond Corporation. Work continued in the 1990s under the auspices of the now defunct Danish Lithosphere Cen- tre, financed by the Danish National Research Foundation. The considerable contribution by the Centre has been made plain in this publication. Reviews by Dennis K. Bird, Stanford University, and Christian Tegner, Aarhus University, have resulted in numerous detailed and valuable amendments to the manuscript. I am also very grateful to my Inuit friends, particularly the late Ulrik Pîvât and his son Abia and the Uitsatikitseq family, all of Kuummiut, for hospitality and transport over the years.

Maps shown in Figs 9 and 10 are compiled from unpublished maps by Dennis K. Bird, Stanford University, Christian Tegner, Aarhus University, and Stefan Bernstein and Nicholas Rose (now Avannaa Resources Ltd, Copenhagen) made in 1987, 1988, 1989 and 1990 and funded by the Danish Lithosphere Centre and NSF-EAR grants no. 84-18129, 86-06256, 88-03754 and 90-06962. 


\section{References}

Abbott, D. \& Deer, W.A. 1972: Geological investigations in East Greenland 9. The gabbro cumulates of the Kap Edvard Holm lower layered series. Meddelelser om Grønland 190(6), 1-42.

Abrahamsen, N. \& Nordgerd, P. 1994: Rock magnetism of Tertiary volcanics from North-East Greenland. Rapport Grønlands Geologiske Undersøgelse 162, 195-200.

Ahlmann, H.W. 1941: Studies in northeast Greenland, 1939-1940. Part 1. The main morphological features of northeast Greenland. Geografiske Annaler 23, 148-182.

Andersen, J.C.Ø., Rasmussen, H., Nielsen, T.F.D. \& Ronsbo, J.G. 1997: The Triple Group and the Platinova gold and palladium deposit in the Skaergaard intrusion. Part 1. Geometry and ore petrography. Economic Geology 93, 488-509.

Andreasen, R., Peate, D.W. \& Brooks, C.K. 2004: Magma plumbing systems in large igneous provinces: inferences from cyclical variations in Palaeogene East Greenland basalts. Contributions to Mineralogy and Petrology 147, 438-452, http://dx.doi. org/10.1007/s00410-004-0566-2

Anwar, Y.M. 1955: Geological investigations in East Greenland. Part 5. The petrography of the Prinsen af Wales Bjerge lavas. Meddelelser om Grønland 135(1), 1-31.

Archer, S.G., Bergman, S.C., Iliffe, J., Murphyn, C.M. \& Thornton, M. 2005: Palaeogene igneous rocks reveal new insights into the geodynamic evolution and petroleum potential of the Rockall Trough, NE Atlantic Margin. Basin Research 17, 171-201, http://dx.doi.org/10.1111/j.1365-2117.2005.00260.x

Armitage, J.J., Henstock, T.J., Minshull, T.A. \& Hopper, J.R. 2008: Modelling the composition of melts formed during continental breakup of the Southeast Greenland margin. Earth and Planetary Science Letters 269, 248-258, http://dx.doi.org/10.1016/j. epsl.2008.02.024

Arnason, J.G. \& Bird, D.K. 2000: A gold- and platinum-mineralized layer in gabbros of the Kap Edvard Holm Complex: field, petrologic, and geochemical relations. Economic Geology 95, 945-970.

Arnason, J.G., Bird, D.K., Bernstein, S. \& Kelemen, P. 1997a: Gold and platinum group mineralization in the Kruuse Fjord gabbro complex, East Greenland. Contributions to Mineralogy and Petrology 92, 490-501.

Arnason, J. G., Bird, D.K., Bernstein, S., Rose, N.M. \& Manning, C.E. 1997b: Petrology and geochemistry of the Kruuse Fjord gabbro complex, East Greenland. Geological Magazine 134, 67-89.

Aubrey, M.-P., Swisher III, C.C., Kent, D.V. \& Bergren, W.A. 2003: Comment on paper 'Palaeogene time scale miscalculation: Evidence from the dating of the North Atlantic Igneous province' Geology 31, 468 only.

Backlund, H.G. \& Malmquist, D. 1932: Zur Geologie und Petrographie der nordgrönländischen Basaltformation. Teil 1. Die basische Reihe. Meddelelser om Grønland 87(5), 61 pp.

Barfod, G.H., Otero, O. \& Albarède, F. 2003: Phosphate Lu-Hf geochronology. Chemical Geology 200, 241-253, http://dx.doi. org/10.1016/S0009-2541(03)00202-X

Barker, A.K., Baker, J.A. \& Peate, D.W. 2006: Interaction of the rifting East Greenland margin with a zoned ancestral mantle Iceland plume. Geology 34, 481-484, http://dx.doi.org/10.1130/ G22366.1

Bearth, P. 1959: On the alkali massif of the Werner Bjerge in East Greenland. Meddelelser om Grønland 153, 63 pp.

Beckinsale, R.D., Brooks, C.K. \& Rex, D.C. 1970: K-Ar ages for the Tertiary of East Greenland. Bulletin of the Geological Society of Denmark 20, 27-37.

Berggren, W.A., Kent, D.V., Swisher III, C.C. \& Aubrey, M.-P. 1995: A revised Cenozoic geochronology and chronostratigraphy. In: Berggren, W.A., Kent, D.V. Aubrey, M.-P. \& Hardenbol, J. (eds): Geochronology, time-scales and global stratigraphic correlation: framework for an historical geology. Society for Economic Paleontologists and Mineralogists, Special Publications 54, 129-212.

Bernstein, S. 2006: In situ fractional crystallization of a mafic pluton: Microanalytical study of a Palaeogene gabbronorite plug in East Greenland. Lithos 92, 222-237, http://dx.doi.org/10.1016/j.lithos.2006.03.034

Bernstein, S. \& Bird, D.K. 2000. Formation of wehrlites through dehydration of metabasalt xenoliths in layered gabbros of the Noe-Nygaard intrusion, Southeast Greenland. Geological Magazine 137, 109-128.

Bernstein, S. \& Brooks, C.K. 1998: Mantle xenoliths from Tertiary lavas and dykes on Ubekendt Ejland, West Greenland. Geology of Greenland Survey Bulletin 180, 152-158.

Bernstein, S., Rosing, M.T., Brooks, C.K. \& Bird, D.K. 1992: An ocean-ridge type magma chamber at a passive volcanic continental margin - The Kap Edvard Holm layered gabbro complex, East Greenland. Geological Magazine 129, 437-456.

Bernstein, S., Kelemen, P.B. \& Brooks, C.K. 1996: Evolution of the Kap Edvard Holm Complex: a mafic intrusion at a rifted continental margin. Journal of Petrology 37, 497-519.

Bernstein, S., Kelemen, P.B. \& Brooks, C.K. 1998a: Depleted spinel harzburgite xenoliths in Tertiary dykes from East Greenland: restites from high degree melting. Earth and Planetary Science Letters 154, 221-235.

Bernstein, S., Kelemen, P.B., Tegner, C., Kurz, M.D., Blusztajn, J. \& Brooks, C.K. 1998b: Post-breakup basaltic magmatism along the East Greenland Tertiary rifted margin. Earth and Planetary Science Letters 160, 845-862.

Bernstein, S., Leslie, A.G., Higgins, A.K. \& Brooks, C.K. 2000: Tertiary alkaline volcanics of the Nunatak Region, North-East Greenland: new observations and comparison with Siberian maymechites. Lithos 53, 1-20.

Bernstein, S., Brooks, C.K. \& Stecher, O. 2001: Enriched component of the Proto-Icelandic mantle plume revealed in alkaline 
Tertiary lavas from East Greenland. Geology 29, 859-862.

Bernstein, S., Hanghøj, K., Kelemen, P.B. \& Brooks, C.K. 2006: Ultra-depleted, shallow cratonic mantle beneath West Greenland: dunitic xenoliths from Ubekendt Ejland. Contributions to Mineralogy and Petrology 152, 335-347.

Bernstein, S., Kelemen, P.B. \& Hanghøj, K. 2007: Consistent olivine $\mathrm{Mg} \#$ in cratonic mantle reflects Archean mantle melting to the exhaustion of orthopyroxene. Geology 35, 459-462, http:// dx.doi.org/10.1130/G23336A.1

Beutel, E., van Wijk J., Ebinger, C., Keir, D. \& Agostini, A. 2010: Formation and stability of magmatic segments in the Main Ethiopian and Afar rifts. Earth and Planetary Science Letters 293, 225-235, http://dx.doi.org/10.1016/j.epsl.2010.02.006

Bird, D.K., Rosing, M.T., Manning, C.E. \& Rose, N.M. 1985: Geologic field studies of the Miki Fjord area, East Greenland. Bulletin of the Geological Society of Denmark 34, 219-236.

Bird, D.K., Rogers, R.D. \& Manning, C.E. 1986: Mineralized fracture systems of the Skaergaard intrusion, East Greenland. Meddelelser om Grønland, Geoscience 16, 68 pp.

Bird, D.K., Manning, C.E. \& Rose, N.M. 1988: Hydrothermal alteration of Tertiary layered gabbros, East Greenland. American Journal of Science 288, 405-57.

Bird, D.K., Brooks, C.K., Gannicott, R.A. \& Turner, P.A. 1991: A gold-bearing horizon in the Skaergaard intrusion, East Greenland. Economic Geology 86, 1083-1092.

Bird, D.K., Arnason, J.G., Brandriss, M.E., Nevle, R.J., Radford, G., Bernstein, S., Gannicott, R.A. \& Kelemen, P.B. 1995: A gold-bearing horizon in the Kap Edvard Holm Complex, East Greenland. Economic Geology 90, 1288-1300.

Birkenmajer, K. 1972: Report on investigations of Tertiary sediments at Kap Brewster, Scoresby Sund, East Greenland. Rapport Grønlands Geologiske Undersøgelse 48, 85-91.

Bizzarro, M. \& Stevenson, R.K. 2003: Major element composition of the lithospheric mantle under the North Atlantic craton: evidence from peridotite xenoliths of the Sarfartoq area, southwestern Greenland. Contributions to Mineralogy and Petrology 146, 223-240, http://dx.doi.org/10.1007/s00410-003-0499-1

Björnsson, A. 1985: Dynamics of crustal rifting in NE Iceland. Journal of Geophysical Research 90, 10151-10162, http:// dx.doi.org/10.1029/JB090iB12p10151

Blank, H.R. \& Gettings, M.E. 1973: Subsurface form and extent of the Skaergaard intrusion, East Greenland. Transactions of the American Geophysical Union 54, 507 only.

Blichert-Toft, J., Lesher, C.E. \& Rosing, M.T. 1992: Selectively contaminated magmas of the Tertiary East Greenland macrodike complex. Contributions to Mineralogy and Petrology 110, 154-172.

Bott, M.H.P. 1987: The continental margin of central East Greenland in relation to North Atlantic plate tectonic evolution. Journal of the Geological Society (London) 144, 561-568.

Brandriss, M.E. \& Bird, D.K. 1999: Effects of $\mathrm{H}_{2} \mathrm{O}$ on phase relations during crystallization of gabbros in the Kap Edvard Holm Complex. Journal of Petrology 40, 1037-64.

Brandriss, M.E., Nevle, R.J., Bird, D.K. \& O’Neil, J.R. 1995: Imprint of meteoric water on the stable isotope compositions of igneous and secondary minerals, Kap Edvard Holm Complex, East Greenland. Contributions to Mineralogy and Petrology 121, 74-86.

Brandriss, M.E., Bird, D.K., O’Neil, J.R. \& Cullers, R.L. 1996: Dehydration, partial melting and assimilation of metabasaltic xenoliths in gabbros of the Kap Edvard Holm Complex, East Greenland. American Journal of Science 296, 333-93.

Braun, J. 2010: The surface expression of mantle dynamics. Nature Geoscience 3, 825-833, http://dx.doi.org/10.1038/NGEO1020

Brooks, C.K. 1973: Rifting and doming in southern East Greenland. Nature Physical Science 244, 23-25.

Brooks, C.K. 1977: An example of magma mixing from the Kialineq district of East Greenland. Bulletin of the Geological Society of Denmark 26, 77-83.

Brooks, C.K. 1979: Geomorphological observations at Kangerdlugssuaq, East Greenland. Meddelelser om Grønland, Geoscience 1, 1-21.

Brooks, C.K. 1985a: Vertical crustal movements in the Tertiary of central East Greenland: a continental margin at a hot spot. Zeitschrift für Geomorphologie Supplement 54, 101-117.

Brooks, C.K. 1985b: L.R.Wager and the geology of East Greenland. In: Drake, E.T. \& Jordan, W.F. (eds): Geologists and ideas: A history of North American geology. Geological Society of America, Centennial Special Issue 1, 237-250.

Brooks, C.K. 1990: Wager, Laurence Rickard. Dictionary of Scientific Biography, Supplement II, 968-970. New York: Charles Schribner's Sons.

Brooks, C.K. 1991a: The Kræmer Ø syenite, Kangerdlugssuaq: preliminary description of one of the voluminous oversaturated syenites of the East Greenland Tertiary. Bulletin of the Geological Society of Denmark 38, 145-151.

Brooks, C.K. 1991b: New occurrences of undersaturated syenites from the southern Blosseville Coast, East Greenland. Bulletin of the Geological Society of Denmark 38, 153-159.

Brooks, C.K. 2006: When the Sun died over northern Europe: the unique geology of Denmark's inland islands. Geology Today 22, 180-196.

Brooks, C.K. 2009: The Caledonides of East Greenland - tales of the birth and death of oceans. Geology Today 25, 94-99.

Brooks, C.K. \& Gill, R.C.O. 1982: Compositional variation in the pyroxenes and amphiboles of the Kangerdlugssuaq intrusion, East Greenland: further evidence for the crustal contamination of syenite magma. Mineralogical Magazine 45, 1-9.

Brooks, C.K. \& Gleadow, A.J.W. 1977: A fission track age for the Skaergaard intrusion and the age of the East Greenland basalts. Geology 5, 539-540.

Brooks, C.K. \& Nielsen, T.F.D. 1982a: The Phanerozoic development of the Kangerdlugssuaq area, East Greenland. Meddelelser om Grønland, Geoscience 9, 1-30.

Brooks, C.K. \& Nielsen, T.F.D. 1982b: Early stages in the differentiation of the Skaergaard magma as revealed by a closely related suite of dyke rocks. Lithos 11, 1-14.

Brooks, C.K. \& Nielsen, T.F.D. 1990: The differentiation of the Skaergaard intrusion. A discussion of Hunter \& Sparks (Contrib. Mineral. Petrol. 95: 451-461). Contributions to Mineralogy and 
Petrology 104, 244-247.

Brooks, C.K. \& Platt, J.G. 1975: Kaersutite-bearing gabbro inclusions and the late dike swarm of Kangerdlugssuaq, East Greenland. Mineralogical Magazine 40, 259-283.

Brooks, C.K. \& Rucklidge, J.C. 1973: A Tertiary lamprophyre dike with high pressure xenoliths and megacrysts from Wiedemanns Fjord, East Greenland. Contributions to Mineralogy and Petrology 42, 197-212.

Brooks, C.K. \& Rucklidge, J.C. 1974: Strongly undersaturated Tertiary volcanic rocks from the Kangerdlugssuaq area. East Greenland. Lithos 7, 239-248.

Brooks, C.K. \& Rucklidge, J.C. 1976: Tertiary peralkaline rhyolite dikes from the Skaergaard area, Kangerdlugssuaq, East Greenland. Meddelelser om Grønland 197(3), 27 pp.

Brooks, C.K., Rønsbo, J.G. \& Nielsen, T.F.D. 1975: Leucite from East Greenland: a new petrographic sub-province of the Tertiary North Atlantic Province. Bulletin of the Geological Society of Denmark 24, 93-98.

Brooks, C.K., Fawcett, J.J. \& Gittins, J. 1976a: Caledonian magmatic activity in south-eastern Greenland. Nature 260, 694-696.

Brooks, C.K., Nielsen, T.F.D. \& Petersen, T.S. 1976b: The Blosseville Coast basalts of East Greenland: composition and temporal variations. Contributions to Mineralogy and Petrology 58, 279-292.

Brooks, C.K., Pedersen, A.K. \& Rex, D.C. 1979: The petrology and age of alkaline mafic lavas from the nunatak zone of central East Greenland. Bulletin Grønlands Geologiske Undersøgelse 133, 28 pp.

Brooks, C.K., Fawcett, J.J. Gittins, J. \& Rucklidge, J.C. 1981: The Batbjerg complex, East Greenland: a unique ultrapotassic Caledonian intrusion. Canadian Journal of Earth Sciences 18, 274-285

Brooks, C.K., Engell, J., Larsen, L.M \& Pedersen, A.K. 1982: Mineralogy of the Werner Bjerge alkaline complex, East Greenland. Meddelelser om Grønland, Geoscience 7, 35 pp.

Brooks, C.K., Schønwandt, H.-K. \& Stenstrop, G. 1987: Reconnaissance for economic minerals in the Kangerdlugssuaq area, East Greenland. Rapport Grønlands Geologiske Undersøgelse 135, 66-68.

Brooks, C.K., Dawes, P.R. \& Soper, N.J. 1989: The Sulugssut intrusive complex: a new Tertiary alkaline centre in East Greenland. Rapport Grønlands Geologiske Undersøgelse 146, 95-100.

Brooks, C.K. et al. 1996: The East Greenland volcanic rifted margin - onshore DLC fieldwork. Bulletin Grønlands Geologiske Undersøgelse 172, 95-102.

Brooks, C.K., Tegner, C., Stein, H. \& Thomassen, B. 2004: ReOs and ${ }^{40} \mathrm{Ar} /{ }^{39} \mathrm{Ar}$ ages of porphyry molybdenum deposits at the East Greenland volcanic rifted margin. Economic Geology 99, 1215-1222.

Brown, P.E. 1973: A layered plutonic complex of alkali basalt parentage: the Lilloise intrusion, east Greenland. Journal of the Geological Society (London) 129, 405-418.

Brown, P.E. \& Becker, S.M. 1986: Fractionation, hybridisation and magma-mixing in the Kialineq centre East Greenland. Contributions to Mineralogy and Petrology 92, 57-70.
Brown, P.E. \& Farmer, D.G. 1972: Size-graded layering in the Imilik gabbro, East Greenland. Geological Magazine 108, 465-575.

Brown, P.E., van Breemen, O., Noble, R.H. \& Macintyre, R.M. 1977: Mid Tertiary activity in East Greenland - the Kialineq complex. Contributions to Mineralogy and Petrology 64, 109122.

Brown, P.E., Brown, R.D., Chambers, A.D. \& Soper, N.J. 1978: Fractionation and assimilation in the Borgtinderne syenite, East Greenland. Contributions to Mineralogy and Petrology 67, 2534.

Brown, P.E., Tocher, F.E. \& Chambers, A.D. 1982: Amphiboles in the Lilloise intrusion, East Greenland. Mineralogical Magazine 45, 47-54

Brown, P.E., Chambers, A.D. \& Becker, S.M. 1987: A large softsediment fold in the Lilloise intrusion, East Greenland. In: Parsons, I. (ed.): Origins of igneous layering, 125-143. Dordrecht: D. Reidel Publishing Company.

Brown, P.E., Evans, I.B. \& Becker, S.M. 1996: The Prince of Wales Formation - post-flood basalt alkali volcanism in the Tertiary of East Greenland. Contributions to Mineralogy and Petrology 123, 424-434.

Brown, P.E., Evans, I.B. \& Becker, S.M. 2000: Alkaline basaltic volcanism in the Tertiary of central East Greenland - the Trekantnunatakker. Transactions of the Royal Society of Edinburgh, Earth Science 90, 165-172.

Buchwald, V.F. \& Mosdal, G. 1985: Meteoritic iron, telluric iron and wrought iron in Greenland. Meddelelser om Grønland, Man $\&$ Society $9,52 \mathrm{pp}$.

Callot, J.-P., Geoffroy, L. \& Brun, J.-P. 2001: Development of volcanic passive margins: three-dimensional laboratory models. Tectonics 21, (1052) 13 pp., http://dx.doi.org/10.1029/2001TC901019

Callot, J.-P., Geoffroy, L., Aubourg, C., Pozzi, J.P. \& Mege, D. 2002: Magma flow directions of shallow dykes from the East Greenland volcanic margin inferred from magnetic fabric studies. Tectonophysics 335, 313-329.

Campbell, I.H. 2007: Testing the plume theory. Chemical Geology 241, 153-176, http://dx.doi.org/10.1016/j.chemgeo.2007.01.024

Campbell, I.H. \& Griffiths, R.W. 1990: Implications of mantle plume structure for the evolution of flood basalts. Earth and Planetary Science Letters 99, 79-93.

Chalmers, J.A., Larsen, L.M. \& Pedersen, A.K. 1995: Widespread Paleocene volcanism around the northern North Atlantic and Labrador Sea: evidence for a large, hot, early plume head. Journal of the Geological Society (London) 152, 965-969.

Chalmers, J.A., Pulvertaft, T.C.R., Marcussen, C. \& Pedersen, A.K. 1999a: New insights into the structure of the Nuussuaq Basin, central West Greenland. Marine and Petroleum Geology 16, 197-224.

Chalmers, J.A., Whittaker, R.C., Skaarup, N. \& Pulvertaft, T.C.R. 1999b: Discussion on the coastal flexure of Disko (West Greenland), onshore expression of the 'oblique reflectors'. Journal of the Geological Society (London) 156, 1051-1055.

Chalmers, J.A., Pulvertaft, T.C.R., Marcussen, C. \& Pedersen, A.K. 2001: Reply to Dr L. Geoffroy et al. Marine and Petroleum Geo- 
logy 18, 953-957.

Chambers, A.D. \& Brown, P.E. 1995: The Lilloise intrusion, East Greenland: fractionation of a hydrous alkali picritic magma. Journal of Petrology 36, 933-963.

Chambers, L.M. \& Fitton, J.G. 2000: Geochemical transitions in the ancestral Icelandic plume: Evidence from the Isle of Mull Tertiary Volcano, Scotland. Journal of the Geological Society (London) $157,261-263$.

Chambers, L.M. \& Pringle, M.S. 1999: Eruption of the British Tertiary Volcanic Province in approximately two million years during Chron 26r. Ninth Annual V.M. Goldschmidt Conference, Lunar Planetary Institute Contribution 971, 51 only.

Chambers, L. M. \& Pringle, M.S. 2001: Age and duration of activity at the Isle of Mull Tertiary igneous centre, Scotland, and confirmation of the existence of subchrons during anomaly 26r. Earth and Planetary Science Letters 193, 333-345.

Chambers, L.M., Pringle, M.S. \& Parrish, R.R. 2005: Rapid formation of the Small Isles Tertiary centre constrained by precise ${ }^{40} \mathrm{Ar} /{ }^{39} \mathrm{Ar}$ and $\mathrm{U}-\mathrm{Pb}$ ages. Lithos 79, 367-384.

Charles, A.J., Condon, D.J., Harding, I.C., Pälike, H., Marshall, J.E.A., Cui, Y., Kump, L. \& Croudace, I.W. 2011: Constraints on the numerical age of the Paleocene-Eocene boundary. Geochemistry, Geophysics, Geosystems 12(6), 19 pp., http:// dx.doi.org/10.1029/2010GC003426

Chenet A.-L., Quidelleur, X., Fluteau, F., Courtillot, V. \& Bajpai, S. 2007: ${ }^{40} \mathrm{~K}-{ }^{40} \mathrm{Ar}$ dating of the main Deccan large igneous province: further evidence of KTB age and short duration. Earth and Planetary Science Letters 263, 1-15, http://dx.doi. org/10.1016/j.epsl.2007.07.011

Christiansen, C.C., Johnsen, O. \& Ståhl, K. 1998: Crystal structure of kupletskite from the Kangerdlugssuaq intrusion, East Greenland. Neues Jahrbuch für Mineralogie Monatshefte 6, 253-264.

Christiansen, C.C., Gault, R.A., Grice, J.D. \& Johnsen, O. 2003: Kochite, a new member of the rosenbuschite group from the Werner Bjerge alkaline complex, East Greenland. European Journal of Mineralogy 15, 551-554, http://dx.doi.org/10.1127/0935$1221 / 2003 / 0015-0551$

Class, C. 2008: Hot arguments to cool off the plume debate? Geology 36, 335-336, http://dx.doi.org/10.1130/focus042008.1

Clift, P.D., Carter, A. \& Hurford, A.J. 1998: The erosional and uplift history of NE Atlantic passive margins: constraints on a passing plume. Journal of the Geological Society (London) 155, 787-800.

Coomer, P.G., Brooks, C.K. \& Thomassen, B. 1974: The isotopic composition of lead in some galenas from East Greenland, 14 pp. Unpublished report, Nordisk Mineselskab, Copenhagen, Denmark.

Coulie, E., Quidelleur, X., Gillot, P.-Y., Courtillot, V., Lefèvre, J.-C. \& Chiesa, S. 2003: Comparative K-Ar and Ar-Ar dating of Ethiopian and Yemenite Oligocene volcanism: implications for timing and duration of the Ethiopian traps. Earth and Planetary Science Letters 206, 477-492.

Courtauld, A. 1936: A Journey in Rasmussen Land. The Geographical Journal LXXXVIII, 193-215.

Courtillot, V. 2002: Evolutionary catastrophes: the science of mass extinctions, 169 pp. Cambridge University Press.

Cox, K.G. 1988: The Karroo Province. In: Macdougall, J.D. (ed.): Continental flood basalts, 239-271. Dordrecht: Kluwer Academic.

Cox, K.G. 1993: Continental magmatic underplating. Philosophical Transactions of the Royal Society (London) 342, 155-166.

Dam, G., Larsen, M., Nøhr-Hansen, H. \& Pulvertaft, T.C.R. 1999: Discussion on the erosional and uplift history of NE Atlantic passive margins: constraints on a passing plume. Journal of the Geological Society (London) 156, 653-656.

Dawes, P.R. 2009: The bedrock geology under the Inland Ice: the next major challenge for Greenland mapping. Geological Survey of Denmark and Greenland Bulletin 17, 57-60.

Deer, W.A. 1976: Tertiary igneous rocks between Scoresby Sund and Kap Gustav Holm, East Greenland. In: Esher, A. \& Watt, W.S. (eds): Geology of Greenland, 386-402. Copenhagen: Grønlands Geologiske Undersøgelse.

Deer, W.A. \& Kempe, D.R.C. 1976: Geological investigations in East Greenland. Part 1. The minor peripheral intrusions, Kangerdlugssuaq, East Greenland. Meddelelser om Grønland 197(4), 25 pp.

Deer, W.A., Kempe, D.R.C. \& Jones, G.C. 1984: Syenitic and associated intrusions of the Kap Edvard Holm region of Kangerdlugssuaq, East Greenland. Meddelelser om Grønland, Geoscience 12, 26 pp.

DePaolo, D.J. \& Manga, M. 2003: Deep origin of hotspots - the mantle plume model. Science 300, 920-921.

Dettrick, R.S., Buhl, P., Vera, E., Mutter, J., Orcutt, J., Madsen, J. \& Brocher, T. 1987: Multi-channel seismic imaging of a crustal magma chamber along the East Pacific Rise. Nature 326, 35-41.

Douglas, J.A.V. 1964: Geological investigations in East Greenland, Part 7. The Basistoppen Sheet. A differentiated basic intrusion into the upper part of the Skaergaard complex, East Greenland. Meddelelser om Grønland 164(5), 1-66.

Egger, H. \& Brückl, E. 2006: Gigantic volcanic eruptions and climatic change in the early Eocene. International Journal of Earth Sciences (Geologische Rundschau) 95, 1065-1070, http:// dx.doi.org/10.1007/s00531-006-0085-7

Eldholm, O., \& Grue, K. 1994: North Atlantic volcanic margins: dimensions and production rates. Journal of Geophysical Research 99, 2955-2968.

Eldholm, O. \& Thomas, E. 1993: Environmental impact of volcanic margin formation. Earth and Planetary Science Letters 117, 319-329.

Eldholm, O., Skogseid, J., Sundvor, E. \& Myhre, A.M. 1990: The Norwegian-Greenland Sea. In: Grantz, A. Johnson L. \& Sweeney, J.F. (eds): The Arctic Ocean Region. The geology of North America L, 351-364. Boulder, Colorado: Geological Society of America.

Ellam, R.M, Upton, B.G.J. \& Fitton, J.G. 1998: Petrogenesis of late magmatism at Hold with Hope, East Greenland. Contributions to Mineralogy and Petrology 133, 51-59.

Elsdon, R. 1969: The structure and intrusive mechanism of Kap Edvard Holm layered gabbro complex, East Greenland. Geological Magazine 106, 45-56.

Elsdon, R. 1971a: Crystallization history of the Upper Layered Se- 
ries, Kap Edvard Holm, East Greenland. Journal of Petrology 12, 499-521.

Elsdon, R. 1971b: Clinopyroxenes from the Upper Layered Series, Kap Edvard Holm, East Greenland. Mineralogical Magazine 38, 49-57.

Elsdon, R. 1972: Iron-titanium oxide minerals in the Upper Layered Series, Kap Edvard Holm, East Greenland. Mineralogical Magazine 38, 946-956.

Elsdon, R. 1982: Autometasomatic alteration of gabbro, Kap Edvard Holm intrusive complex, East Greenland. Mineralogical Magazine 45, 219-225.

Emeleus, C.H. 1955: The granites of the western Mourne Mountains, County Down. Scientific Proceedings of the Royal Dublin Society 27, 35-50.

England, P. \& Molnar, P. 1990: Surface uplift, uplift of rocks, and exhumation of rocks. Geology 18, 1173-1177.

Engen, Ø., Faleide, J.I. \& Dyreng, T.K. 2008: Opening of the Fram Strait gateway: a review of plate tectonic constraints. Tectonophysics 450, 51-69, http://dx.doi.org/10.1016/j.tecto.2008.01.002

Faller, A.M. 1975: Palaeomagnetism of the oldest Tertiary basalts in the Kangerdlugssuaq area of East Greenland. Bulletin of the Geological Society of Denmark 24, 173-178.

Faller, A.M. \& Soper, N.J. 1979: Palaeomagnetic evidence for the origin of the coastal flexure and dyke swarm in central E Greenland. Journal of the Geological Society (London) 136, 737-744.

Fawcett, J.J., Brooks, C.K. \& Rucklidge, J.C. 1973: Chemical petrology of Tertiary flood basalts from the Scoresby Sund area. Meddelelser om Grønland 195(6), 54 pp.

Fehlhaber, K. \& Bird, D.K. 1991: Oxygen isotope exchange and mineral alteration in gabbros of the Lower Layered Series, Kap Edvard Holm Complex, East Greenland. Geology 19, 819-822.

Forsyth, D.A., Morel-a-l'Huissier, P., Asudeh, I. \& Green, A.G. 1986: Alpha Ridge and Iceland - products of the same plume? Journal of Geodynamics 6, 197-214.

Foulger, G.R. 2010: Plates vs. Plumes: A Geological Controversy, 328 pp. Chichester: Wiley-Blackwell.

Foulger, G.R. \& Natland, J.H. 2003: Is 'hotspot' volcanism a consequence of plate tectonics? Science 300, 921-922.

Foulger, G.R., Natland, J.H., Presnall, D.C. \& Anderson, D.L. (eds) 2005: Plates, plumes, and paradigms. Geological Society of America Special Volume 388, 881 pp.

Fram, M. \& Lesher, C. 1997: Generation and polybaric differentiation of East Greenland Early Tertiary flood basalts. Journal of Petrology 38, 231-275.

Gamble, J.A., Wysoczanski, R.J. \& Meighan, I.G. 1999: Constraints on the age of the British Tertiary Volcanic Province from ion microprobe $\mathrm{U}-\mathrm{Pb}$ (SHRIMP) ages for acid igneous rocks from NE Ireland. Journal of the Geological Society (London) 156, 291-299.

Garson, M.S. \& Krs, M. 1976: Geophysical and geological evidence of the relationship of Red Sea transverse tectonics to ancient fractures. Geological Society of America Bulletin 87, 169-181.

Geist, D. \& White, C. 1994: Assimilation and fractionation in adjacent parts of the same magma chamber: Vandfaldsdalen macrodike, East Greenland. Contributions to Mineralogy and Petro- logy 116, 92-107.

Geoffroy, L. 2005: Volcanic passive margins. Comptes Rendus Geoscience 337, 1395-1408, http://dx.doi.org/10.1016/j.crte. 2005.10.006

Geoffroy, L., Gelard, J.P., Lepvrier, C. \& Olivier, P. 1998: The coastal flexure of Disko (West Greenland): onshore expression of the 'oblique reflectors'. Journal of the Geological Society (London) 155, 463-473.

Geoffroy, L., Gelard, J.P., Lepvrier, C. \& Olivier, P. 1999: Discussion on the coastal flexure of Disko (West Greenland): onshore expression of the 'oblique reflectors': Reply. Journal of the Geological Society (London) 156, 1051-1055.

Geoffroy, L., Callot, J.-P. Scaillet, S., Skuce, A., Gélard, J.P., Ravilly, M., Angelier, J., Bonin, B., Cayet, C., Perrot, K. \& Lepvrier, C. 2001a: Southeast Baffin volcanic margin and the North American-Greenland plate separation. Tectonics 20, 566-584.

Geoffroy, L., Gélarel, J.P., Aïte, G. \& Cattanéo, G. 2001b: Comments on "New insights into the structure of the Nuussuaq Basin, Central West Greenland" from Chalmers, Pulvertaft, Marcussen, $\&$ Pedersen. Marine and Petroleum Geology 18, 947-952.

Geyti A. \& Thomassen, B. 1984: Molybdenum and precious metal mineralization at Flammefjeld, southeast Greenland. Economic Geology 79, 1921-1929.

Gibson, D., Lux, D.R. \& Meighan, I.G. 1995: New ${ }^{40} \mathrm{Ar} /{ }^{39} \mathrm{Ar}$ ages for the Mourne Mountains granites, north-east Ireland. Irish Journal of Earth Sciences 14, 25-35.

Gill, R.C.O., Nielsen, T.F.D., Brooks, C.K. \& Ingram, G.A. 1988: Tertiary volcanism in the Kangerdlugssuaq region, East Greenland: trace element geochemistry of the lower lavas and tholeiitic dyke swarms. In: Morton, A.C. \& Parson, L.M. (eds): Early Tertiary Volcanism and the Opening of the NE Atlantic. Geological Society Special Publications (London) 39, 161-179.

Gisselø, P.G. 2001: Sorgenfri Gletscher sill complex, East Greenland. Solidification mechanisms of sheet-like bodies and the role of sill complexes in large igneous complexes, 109 pp. Unpublished Ph.D. thesis, University of Aarhus, Denmark.

Gittins, J., Fawcett, J.J., Brooks, C.K. \& Rucklidge, J.C. 1980: Intergrowths of nepheline-potassium feldspar and kalsilite-potassium feldspar. A re-examination of the 'pseudoleucite problem'. Contributions to Mineralogy and Petrology 73, 119-126.

Glasby, G. 2007a: Skaergaard, Everest and more... on the life and work of Lawrence Wager. Geoscientist 17, http://www.geolsoc. org.uk/gsl/geoscientist/features/page3007.html

Glasby, G.P. 2007b: The Life and Times of Lawrence Wager. Geochemical News 131, http://www.geochemsoc.org/publications/geochemicalnews/gn131apr07/thelifeandtimesoflawrencew

Gleadow, A.J.W. \& Brooks, C.K.1979: Fission track dating, thermal histories and tectonics of igneous intrusions in East Greenland. Contributions to Mineralogy and Petrology 71, 45-60.

Gradstein, F.M., Ogg, J.G. \& Smith, AG. (eds): 2005: A geologic time scale 2004, 610 pp. Cambridge: Cambridge University Press.

Gras, M.A., Heister, L.E. \& Lesher, C.E. 2004: Petrology and geochemistry of the Milne Land Formation, central east Greenland flood basalt province. Goldschmidt Geochemistry Confe- 
rence, Copenhagen 2004. Abstract A588.

Green P.F., Japsen, P., Chalmers, J.A. \& Bonow, J.M. 2011: Thermochronology, erosion surfaces and missing section in West Greenland. Journal of the Geological Society (London) 168, 817-829, http://dx.doi.org/10.1144/0016-76492010-124

Guarnieri, P. 2011: Analysis of Palaeogene strike-slip tectonics along the southern East Greenland margin (Sødalen area). Geological Survey of Denmark and Greenland Bulletin 23, 65-68.

Gudlaugsson, S.T., Gunnarsson, Sand, M. \& Skogseid, J. 1988: Tectonic and volcanic events at the Jan Mayen Ridge microcontinent. In: Morton, A.C. Parson, L.M. (eds): Early Tertiary volcanism and the opening of the NE Atlantic. Geological Society Special Publications (London) 39, 85-93.

Haas, K.M. \& Devey, C.W. 1994: The petrology and geochemistry of Vesteris Seamount, Greenland Basin - an intraplate volcano of non-plume origin. Journal of Petrology 35, 295-328.

Hailwood, E.A. 1977: Configuration of the geomagnetic field in early Tertiary times. Journal of the Geological Society (London) 133, 23-36.

Hald, N. 1978: Tertiary igneous activity at Giesecke Bjerge, northern East Greenland. Bulletin of the Geological Society of Denmark 27, 109-115.

Hald, N. 1996: Early Tertiary lavas and sills on Traill $\varnothing$ and Geographical Society $\varnothing$, northern East Greenland: petrography and geochemistry. Bulletin Grønlands Geologiske Undersøgelse 171, 29-43.

Hald, N. \& Tegner, C. 2000: Composition and age of Tertiary sills and dykes, Jameson Land Basin, East Greenland: Relation to regional flood volcanism. Lithos 54, 207-233.

Hald, N. \& Waagstein, R. 1983: Silicic basalts from the Faeroe Islands: evidence of crustal contamination. In: Bott. M.H.P et al. (eds): Structure and Development of the Greenland-Scotland Ridge, 343-349. New York/London: Plenum Press.

Hamilton M.A. \& Brooks, C.K. 2004: A precise U-Pb zircon age for the Skaergaard intrusion. Goldschmidt Geochemistry Conference, Copenhagen 2004. Abstract $\mathbf{A 5 8 7 .}$

Hamilton, M.A., Pearson, D.G., Thompson, R.N., Kelley, S.P. \& Emeleus, C.H. 1998: Rapid eruption of Skye lavas inferred from $\mathrm{U}-\mathrm{Pb}$ and Ar-Ar dating of the Rum and Cuillin plutonic complexes. Nature 394, 260-263.

Hamilton, M.A., Pearson, D.G., Thompson, R.N. \& Emeleus, C.H. 1999: Precise U-Pb zircon dating of late-stage acid magmatism in the British Tertiary Volcanic Province. In: Jolley, D. \& Bell, B. (eds): The North Atlantic Igneous Province: magmatic controls on sedimentation. Geological Society Special Publications (London) 197, 23 only.

Hanghøj, K., Kelemen, P., Bernstein, S., Blusztajn, J. \& Frei, R. 2001: Osmium isotopes in the Wiedemann Fjord mantle xenoliths: a unique record of cratonic mantle formation by melt depletion in the Archaean. Geochemistry, Geophysics, Geosystems 2, http://dx.doi.org/10.1029/2000GC000085

Hanghøj, K., Storey, M. \& Stecher, O. 2003: An isotopic and trace element study of the East Greenland Tertiary dyke swarm: constraints on temporal and spatial rifting. Journal of Petrology $\mathbf{4 4}$, 2081-2112.
Hansen, D.M. 2006: The morphology of intrusion-related vent structures and their implications for constraining the timing of intrusive events along the NE Atlantic margin. Journal of the Geological Society (London) 163, 789-800, http://dx.doi. org/10.1144/0016-76492004-167

Hansen, H. \& Nielsen, T.F.D. 1999: Crustal contamination in Palaeogene East Greenland flood basalts: plumbing system evolution during continental rifting. Chemical Geology 157, 89-118.

Hansen, H., Rex, D.C., Guise, P.G. \& Brooks, C.K. 1995: ${ }^{40} \mathrm{Ar} /{ }^{39} \mathrm{Ar}$ ages on early Tertiary basalts from the Scoresby Sund area, East Greenland. Newsletters on Stratigraphy 32, 103-116.

Hansen, H.J., Pedersen, A.K., Duncan, R.A., Bird, D.K., Brooks, C.K., Fawcett, J.J., Gittins, J., Gorton, M. \& O’Day, P. 2002: Volcanic stratigraphy of the southern Prinsen af Wales Bjerge region, East Greenland. In: Jolley, D.W. and Bell, B.R. (eds): The North Atlantic Igneous Province: stratigraphy, tectonic and magmatic processes. Geological Society Special Publications (London) 197, 183-218.

Hansen, K. 1992: Post-orogenic tectonic and thermal history of a rifted continental margin: the Scoresby Sund area, east Greenland. Tectonophysics 216, 309-326.

Hansen, K. 1996: Thermotectonic evolution of a rifted continental margin: fission track evidence from the Kangerlussuaq area, SE Greenland. Terra Nova 8, 458-469.

Hansen, K. 2000: Tracking thermal history in East Greenland: an overview. Global and Planetary Change 24, 303-309.

Hansen, K. \& Brooks, C.K. 2002: The evolution of the East Greenland margin as revealed from fission track studies. Tectonophysics 349, 93-111.

Hansen, K. \& Reiners, P.W. 2006: Low temperature thermochronology of the southern East Greenland continental margin: evidence from apatite (U-Th)/He and fission track analysis and implications for intermethod calibration. Lithos 92, 117-136, http://dx.doi.org/10.1016/j.lithos.2006.03.039

Hansen, K., Bergman, S.C. \& Henk, B. 2001: The Jameson Land basin (east Greenland): a fission track study of the tectonic and thermal evolution in the Cenozoic North Atlantic spreading regime. Tectonophysics 331, 307-339.

Hardarson, B.S., Fitton, J.G., Ellam, R.M. \& Pringle, M.S. 1997: Rift relocation - a geochemical and geochronological imvestigation of a palaeo-rift in north-west Iceland. Earth and Planetary Science Letters 153, 181-196.

Hargreaves, J. 1991: L.R. Wager: A life 1904-1965, 141 pp. Oxford: Published by the author.

Harlou, R. 2001: Petrology and geochemistry of Tertiary alkaline ultrabasic lavas from the Nunatak Region, North East Greenland, 127 pp. Unpublished MSc thesis, University of Copenhagen, Denmark.

Harpøth, O., Pedersen, J.L., Schønwandt, H.K. \& Thomassen, B. 1986: The mineral occurrences of central East Greenland. Meddelelser om Grønland, Geoscience 17, 138 pp.

Hartley, R. A., Roberts, G.G. White, N. \& Richardson, C. 2011: Transient convective uplift of an ancient buried landscape. Nature Geoscience 4, 562-565, http://dx.doi.org/10.1038/NGEO1191 Heister, L.E., O’Day, P.A., Brooks, C.K., Neuhoff, P.S. \& Bird, 
D.K. 2001: Pyroclastic deposits within the East Greenland Tertiary flood basalts. Journal of the Geological Society (London) 158, 209-284.

Henriksen, N. 2008: Geological history of Greenland, 272 pp. Copenhagen: Geological Survey of Denmark and Greenland.

Herzberg, C. \& Gazel, E. 2009: Petrological evidence for secular cooling in mantle plumes. Nature 458, 619-622, http://dx.doi. org/10.1038/nature07857

Hey, R., Sinton, J.M. \& Duennebier, F.K. 1989: Propagating rifts and spreading centres. In: Winterer, E.L., Hussong, D.M. \& Decker, R.W. (eds): The eastern Pacific Ocean and Hawaii. The Geology of North America N, 161-176. Boulder, Colorado: Geological Society of America.

Hey, R., Martinez, F., Höskuldsson, Á. \& Benediktsdóttir, Á. 2010: Propagating rift model for the V-shaped ridges south of Iceland. Geochemistry, Geophysics, Geosystems 11, 24 pp., http:// dx.doi.org/10.1029/2009GC002865

Higgins, J.C \& Soper, N.J. 1981: Cretaceous-Palaeogene sub-basaltic and intra-basaltic sediments of the Kangerdlugssuaq area, Central East Greenland. Geological Magazine 118, 337-354.

Higgins, A.K. 2010: Exploration history and place names of northern East Greenland. Geological Survey of Denmark and Greenland Bulletin 21, 368 pp.

Higgins, A.K. \& Falsbeek, F. (eds) 2004: East Greenland Caledonides: stratigraphy, structure and geochronology. Geological Survey of Denmark and Greenland Bulletin 6, 93 pp.

Higgins, A.K. et al. 2004: The foreland-propagating thrust architecture of the East Greenland Caledonides $72^{\circ} \mathrm{N}$ to $75^{\circ} \mathrm{N}$. Journal of the Geological Society (London) 161, 1009-1026.

Higgins, A.K., Gilotti, J.A. \& Smith, M.P. (eds) 2008: The Greenland Caledonides: evolution of the northeast margin of Laurentia. Geological Society of America Memoir 202, 368 pp.

Hinz, K., Mutter, J.C., Zehnder, C.M. \& the NGT Study Group 1987: Symmetric conjugation of continent-ocean boundary structures along the Norwegian and East Greenland Margins. Marine and Petroleum Geology 4, 166-187.

Hirschmann, M.M., Renne, P.R. \& McBirney, A.R. 1997: ${ }^{40} \mathrm{Ar} /{ }^{39} \mathrm{Ar}$ dating of the Skaergaard intrusion. Earth and Planetary Science Letters 146, 645-658.

Hoch, E. 1992: First Greenland record of the shark genus Ptychodus and the biogeographic significance of its fossil assemblage. Palaeogeography, Palaeoclimatology, Palaeoecology 92, 277-281.

Hogg, A.J.C., Fawcett, J.J., Gittins, J. \& Gorton, M.P. 1988: Cyclical tholeiitic volcanism and associated magma chambers: eruptive mechanisms in East Greenland. In: Morten, A.C. \& Parson, L.M. (eds): Early Tertiary volcanism and the opening of the NE Atlantic. Geological Society Special Publications (London) 39, 197-200.

Hogg, A.J.C., Fawcett, J.J., Gittins, J. \& Gorton, M.P. 1989. Cyclical variation in composition in continental tholeiites of East Greenland. Canadian Journal of Earth Sciences 26, 534-543.

Holbrook, W.S. et al. 2001: Mantle thermal structure and active upwelling during continental breakup in the North Atlantic. Earth and Planetary Science Letters 190, 251-266.

Hole, M.J. \& Morrison, M.A. 1992: The differentiated dolerite boss, Cnoc Rhaonastil, Islay: a natural experiment in the low pressure differentiation of an alkali olivine-basalt magma. Scottish Journal of Geology 28, 55-69, http://dx.doi.org/10.1144/ sig28010055

Holm, P.M. 1988: Nd, Sr, and Pb isotope geochemistry of the Lower Lavas, E. Greenland Tertiary Igneous Province. In: Morton, A.C. \& Parson, L.M. (eds): Early Tertiary volcanism and the opening of the NE Atlantic. Geological Society Special Publications (London) 39, 181-195.

Holm, P.M. 1991: Radiometric age determinations in the Kærven area, Kangerdlugssuaq, East Greenland Tertiary igneous province: ${ }^{40} \mathrm{Ar} /{ }^{39} \mathrm{Ar}, \mathrm{K} / \mathrm{Ar}$ and $\mathrm{Rb} / \mathrm{Sr}$ isotopic results. Bulletin of the Geolgical Society of Denmark 38, 183-201.

Holm, P.M. \& Prægel, N.-O. 1988: The Tertiary Kærven syenite complex, Kangerdlugssuaq, East Greenland: mineral chemistry and geochemistry. Mineralogical Magazine 52, 435-450.

Holm, P.M. \& Prægel, N.-O. 2006: Cumulates from primitive riftrelated East Greenland Paleogene magmas: Petrological and isotopic evidence from ultramafic complexes at Kælvegletscher and near Kærven. Lithos 92, 251-275, http://dx.doi.org/10.1016/j. lithos.2006.03.036

Holm, P.M., Prægel, N.-O. \& Egeberg, E.D. 1991: Multiple syenite intrusions at Kærven, Kangerdlugssuaq, East Greenland: evidence from the 1986 fieldwork. Bulletin of the Geological Society of Denmark 38, 173-181.

Holm, P.M., Heaman, L.M. \& Pedersen, L.E. 2006: Baddeleyite and zircon $\mathrm{U}-\mathrm{Pb}$ ages from the Kærven area, Kangerlussuaq: implications for the timing of Paleogene continental breakup in the North Atlantic. Lithos 92, 238-250, http://dx.doi. org/10.1016/j.lithos.2006.03.035

Holmes, A. 1918: The basaltic rocks of the Arctic region. Mineralogical Magazine 18, 180-223.

Holness, M.B., Nielsen, T.F.D., Tegner, C. 2006: Textural maturity of cumulates: a record of chamber filling, liquidus assemblage, cooling rate and large-scale convection in mafic layered intrusions. Journal of Petrology 48, 141-157, http://dx.doi. org/10.1093/petrology/egl057

Holness, M.B., Tegner, C., Nielsen, T.F.D., Stripp, G. and Morse, S.A. 2007: A textural record of solidification and cooling in the Skaergaard intrusion, East Greenland. Journal of Petrology 48, 2359-2377, http://dx.doi.org/10.1093/petrology/egm064

Holness, M.B., Stripp, G., Humphreys, M.C.S., Veksler, I.V., Nielsen, T.F.D. \& Tegner, C. 2011: Silicate liquid immiscibility within the crystal mush: late-stage magmatic microstructures in the Skaergaard intrusion, East Greenland. Journal of Petrology 52, 175-222, http://dx.doi.org/10.1093/petrology/egq077

Hooper, P.R. 1997: The Colombia River Flood Basalt Province. In: Mahoney, J.J. \& Coffin, M.F. (eds): Large igneous provinces. Continental, oceanic, and planetary flood volcanism. American Geophysical Union Monograph 100, 1-28.

Hopper, J.R., Dahl-Jensen, T., Holbrook, W.S., Larsen, H.C., Lizarralde, D., Korenaga, J., Kent, G.M. \& Kelemen, P.B. 2003: Structure of the SE Greenland margin from seismic reflection and refraction data: implications for nascent spreading center subsidence and asymmetric crustal accretion during North At- 
lantic opening. Journal of Geophysical Research 108, 2269, 22 pp., http://dx.doi.org/10.1029/2002JB001996

Hughes, C.J. 1956: Geological investigations in East Greenland. Part 6. A differentiated basic sill enclosed in the Skaergaard intrusion, East Greenland and related sills injecting the lavas. Meddelelser om Grønland 137(2), 1-28.

Humphreys, M.C.S. 2009: Chemical evolution of intercumulus liquid, as recorded in plagioclase overgrowth rims from the Skaergaard intrusion. Journal of Petrology 50, 127-145, http://dx.doi. org/10.1093/petrology/egn076

Humphreys, M.C.S. 2011: Silicate liquid immiscibility within the crystal mush: evidence from $\mathrm{Ti}$ in plagioclase from the Skaergaard intrusion. Journal of Petrology 52, 147-174, http://dx.doi. org/10.1093/petrology/egq076

Humphreys, M.C.S. \& Holness, M.B. 2010: Melt-rich segregations in the Skaergaard marginal border series: tearing of a vertical silicate mush. Lithos 119, 181-192, http://dx.doi.org/10.1016/j. lithos.2010.06.006

Hunter, R.H. \& Sparks, R.S.J. 1987: The differentiation of the Skaergaard intrusion. Contributions to Mineralogy and Petrology 95, 451-461.

Irvine, T.N. 1992: Emplacement of the Skaergaard intrusion. Carnegie Institution of Washington Yearbook 91, 91-96.

Irvine, T.N. \& Stoesser, D.B. 1978: Structure of the Skaergaard trough bands. Carnegie Institution of Washington Yearbook 77, 727-732.

Irvine, T.N., Andersen, J.C.Ø. \& Brooks, C.K. 1998: Included blocks (and blocks within blocks) in the Skaergaard intrusion: geological relations and the origins of rhythmic modally graded layers. Bulletin of the Geological Society of America 110, 1398-1447.

Jackson, M.G. \& Carlson, R.W. 2011: An ancient recipe for floodbasalt genesis. Nature 476, 316-320, http://dx.doi.org/10.1038/ nature 10326

Jakobsen, J.K., Veksler, I.V., Tegner, C. \& Brooks, C.K. 2005: Immiscible iron- and silica-rich melts in basalt petrogenesis documented in the Skaergaard intrusion. Geology 33, 885-888, http://dx.doi.org/10.1130/G21724.1

Jakobsen, J.K., Tegner, C., Brooks, C.K., Kent, A.J.R., Lesher, C.E., Nielsen, T.F.D. \& Wiedenbeck, M. 2010: Parental magma of the Skaergaard intrusion: constraints from melt inclusions in primitive troctolite blocks and FG-1 dykes. Contributions to Mineralogy and Petrology 159, 61-79, http://dx.doi.org/10.1007/ s00410-009-0416-3

Jensen, S.M. 1998: Tertiary mineralization and magmatism, East Greenland: lead isotopic evidence for remobilization of continental crust. Chemical Geology 150, 119-144.

Johnsen, O., Petersen, O.V. \& Medenbach, O. 1985: The Gardiner Complex: a new locality in Greenland. Mineralogical Record 16, 485-494.

Johnsen, O., Nielsen, T.F.D. \& Rønsbo, J.G. 1994: Lamprophyllite and barytolamprophyllite from the Tertiary Gardiner Complex, East Greenland. Neues Jahrbuch für Mineralogie Monatshefte 7, 328-336.

Johnsen, O., Grice, J.D. \& Gault, R.A. 1998: Kentbrooksite from the Kangerdlugssuaq intrusion, East Greenland, a new Mn-REE$\mathrm{Nb}-\mathrm{F}$ end-member in a series within the eudialyte group: description and crystal structure. European Journal of Mineralogy 10, $1-13$.

Jolley, D.W. 1998: Early Eocene palynofloras from Holes 915A, 916A, 917A, and 918D, East Greenland. In: Saunders, A.D., Larsen, H.C. \& Wise Jr., S.W.(eds): Proceedings of the Ocean Drilling Program, Scientific Results 152, 221-232, http:// dx.doi.org/10.2973/odp.proc.sr.152.249.1998

Jolley, D.W., Clark, B. \& Kelley, S. 2002: Palaeogene time scale miscalculation: evidence from the dating of the North Atlantic igneous province. Geology 30, 7-10.

Jonk, R., Parnell, J. \& Whitham, A. 2005: Fluid inclusion evidence for a Cretaceous-Palaeogene petroleum system, Kangerlussuaq Basin, East Greenland. Marine and Petroleum Geology 22, 309 330.

Judd, J.W. 1874: On the ancient volcanoes of the Highlands and relations of their products to the Mesozoic strata. Quarterly Journal of the Geological Society (London) 30, 220-302.

Juteau, T., Ernewein, M., Reuber, I., Whitechurch, H. \& Dahl, R. 1988: Duality of magmatism in the plutonic sequence of the Semail Nappe, Oman. Tectonophysics 151, 107-135.

Kapp, H. 1960: Zur Petrologie der Subvulkane zwischen Mesters Vig und Antarctic Havn (Ost Grönland). Meddelelser om Grønland 153(2), 203 pp.

Karson, J.A. \& Brooks, C.K. 1999: Structural and magmatic segmentation of the Tertiary East Greenland volcanic rifted margin. In: MacNiocail, C. \& Ryan, P.D. (eds): Continental tectonics. Geological Society Special Publications (London) 164, 313-338.

Karson, J.A., Hurst, S.D. \& Lonsdale, P. 1992: Tectonic rotations of dikes in fast-spread oceanic crust exposed near Hess Deep. Geology 20, 685-688.

Karson, J.A., Brooks, C.K., Storey, M. \& Pringle, M.S. 1998: Tertiary faulting and pseudotachylytes in the East Greenland volcanic rifted margin: seismogenic faulting during magmatic construction. Geology 26, 39-42.

Katz, H.R. 1952a: Ein Querschnitt durch die Nunatakzone Ostgrönlands ca. $74^{\circ}$ n.B. Meddelelser om Grønland 144(8), 1-64.

Katz, H.R. 1952b: Zur Geologie von Strindbergs Land. Meddelelser om Grønland 111(1), 1-150.

Kempe, D.R.C. 1966: A note on the 201 spacing of some lime-rich alkali feldspars from Kangerdlugsuaq, East Greenland. Mineralogical Magazine 35, 704-714.

Kempe, D.R.C. \& Deer, W.A. 1970: Geological investigations in East Greenland. Part IX. The mineralogy of the Kangerdlugssuaq alkaline intrusion, East Greenland. Meddelelser om Grønland 190(3), 1-95.

Kempe, D.R.C. \& Deer, W.A. 1976: The petrogenesis of the Kangerdlugssuaq alkaline intrusion, East Greenland. Lithos 9, 111123.

Kempe, D.R.C., Deer, W.A. \& Wager, L.R. 1970: Geological investigations in East Greenland. Part VII. The petrology of the Kangerdlugssuaq alkaline intrusion, East Greenland. Meddelelser om Grønland 190(2), 1-49.

Kent, W., Saunders, A.D., Kempton, P.D. \& Gjose, N.C. 1997: 
Rajmahal basalts, eastern India: mantle sources and melt distribution at a volcanic rifted margin. In: Mahoney, J.J. \& Coffin, M.F. (eds): Large igneous provinces. Continental, oceanic, and planetary flood volcanism. American Geophysical Union Monograph 100, 145-182.

Kidd, R.G.W. \& Cann, J.R. 1974: Chilling statistics indicate an ocean-floor spreading origin for the Troodos complex, Cyprus. Earth and Planetary Science Letters 24, 151-155.

Kirchner, G. 1964: Die Molybdän Lagerstätte des Erzberges bei Mestersvig, Ostgrönland. Berg- und Hüttenmännische Monatshefte 109(4), 162-173.

Klausen, M.B. 2006: Similar dyke thickness variation across three volcanic rifts in the North Atlantic region: implications for intrusion mechanisms. Lithos 92, 137-153, http://dx.doi. org/10.1016/j.lithos.2006.03.030

Klausen, M.B. \& Larsen, H.C. 2002: East Greenland coast-parallel dike swarm and its role in continental break-up. In: Menzies, M.A. et al. (eds): Volcanic rifted margins. Geological Society of America Special Paper 362, 133-158.

Klein, E. \& Langmuir, C. 1987: Global correlations of ocean ridge basalt chemistry with axial depth and crustal thickness. Journal of Geophysical Research 92(B8), 8089-8115.

Knox, R.W.O'B. 1996: Correlation of the early Paleogene in Northwest Europe: an overview. In: Knox, R.W.O’B., Corfield, R.M. \& Dunay, R.E. (eds): Correlation of the Early Paleogene in Northwest Europe. Geological Society Special Publications (London) 101, 1-11.

Kofoed, J.A.C. 1998: Petrologisk og geokemisk undersøgelse af Nedre Triassiske alkaline lamprofyrgange fra Liverpool Land, Østgrønland, 125 pp. Unpublished MSc thesis, University of Copenhagen, Denmark.

Korenaga, J. \& Kelemen, P.B. 2000: Major element heterogeneity in the mantle source of the North Atlantic igneous province. Earth and Planetary Science Letters 184, 251-268.

Korenaga, J., Holbrook, W.S., Kent, G., Kelemen, P.B., Detrick, R., Hopper, J. \& Dahl-Jensen, T. 2000: Crustal structure of the southeast Greenland margin from joint refraction and reflection seismic tomography. Journal of Geophysical Research 105, 21591-21614.

Korenaga, J., Kelemen, P.B. \& Holbrook, W.S. 2002: Methods for resolving the origin of large igneous provinces from crustal seismology. Journal of Geophysical Research 107, 2178, http:// dx.doi.org/10.1029/2001JB001030

Krokström, T. (with appendix by H. Backlund) 1944: Petrological studies on some basaltic rocks from East Greenland. Meddelelser om Grønland 103(6), 75 pp.

Larsen, H.C. 1978: Offshore continuation of East Greenland dike swarm and North Atlantic formation. Nature 274, 220-223.

Larsen, H.C. 1984: Geology of the East Greenland shelf. In: Spencer, A.M. (ed.): Petroleum geology of the north European margin. Norwegian Petroleum Society, 329-339. London: Graham $\&$ Trotman.

Larsen, H.C. 1988: A multiple and propagating rift model for the NE Atlantic. In: Morton, A.C. \& Parson, L.M. (eds): Early Tertiary volcanism and the opening of the NE Atlantic. Geological
Society Special Publications (London) 39, 157-158.

Larsen, H.C. 1990: The East Greenland shelf. In: Grantz, A., Johnson L. \& Sweeney, J.F. (eds): The Arctic Ocean region. The geology of North America L,185-210. Boulder, Colorado: Geological Society of America.

Larsen, H.C. \& Duncan, R.A. 1996: Introduction: Leg 163 background and objectives. In: Duncan, R.A. et al. (eds): Proceedings of the Ocean Drilling Program, Initial Reports 163, 1-5.

Larsen, H.C. \& Jakobsdóttir, S. 1988: Distribution, crustal properties and significance of seawards-dipping, sub-basement reflectors off E. Greenland. In: Morton, A.C. \& Parsons, L.M. (eds): Early Tertiary volcanism and the opening of the NE Atlantic. Geological Society Special Publications (London) 39, 95-114, http:// dx.doi.org/10.1144/GSL.SP.1988.039.01.10

Larsen, H.C. \& Marcussen, C. 1992: Sill intrusion, flood basalt emplacement and deep crustal structure of the Scoresby Sund region, East Greenland. In: Storey, B.C., Alabaster, T. \& Pankhurst, R.J. (eds): Magmatism and the causes of continental break-up. Geological Society Special Publications (London) 68, 365-386.

Larsen, H.C. \& Saunders, A.D. 1998: Tectonism and volcanism at the southeast Greenland rifted margin: a record of plume impact and later continental rupture. In: Saunders, A.D., Larsen, H.C. \& Wise Jr., S.W. (eds): Proceedings of the Ocean Drilling Program, Scientific Results 152, 503-533, http://dx.doi. org/10.2973/odp.proc.sr.152.240.1998

Larsen, H.C., Brooks, C.K., Hopper, J.R., Jensen, T.D., Pedersen, A.K., Nielsen, T.F.D. \& field parties 1995: The Tertiary opening of the North Atlantic: DLC investigations along the east coast of Greenland. Rapport Grønlands Geologiske Undersøgelse 165, 106-115.

Larsen, L.M. \& Watt, W.S. 1985: Episodic volcanism during breakup of the North Atlantic: evidence from the East Greenland plateau basalts. Earth and Planetary Science Letters 73, 105-116.

Larsen, L.M., Watt, W.S. \& Watt, M. 1989: Geology and petrology of the Lower Tertiary plateau basalts of the Scoresby Sund region, East Greenland. Bulletin Grønlands Geologiske Undersøgelse 157, 164 pp.

Larsen, L.M., Waagstein, R., Pedersen, A.K. \& Storey, M. 1999: Trans-Atlantic correlation of the Palaeogene volcanic successions in the Faeroe Islands and East Greenland. Journal of the Geological Society (London) 156, 1081-1095.

Larsen, L.M., Fitton J.G. \& Pedersen, A.K. 2003: Palaeogene volcanic ash layers in the Danish Basin: compositions and source areas in the North Atlantic Igneous Province. Lithos 71, 47-80, http:// authors.elsevier.com/sd/article/S0024493703001324

Larsen, M. \& Whitham A.G. 2005: Evidence for a major sediment input point into the Faroe-Shetland basin from the Kangerlussuaq region of southern East Greenland. In: Doré, A.G. \& Vining, B.A. (eds): Petroleum geology: North-West Europe and global perspectives. Proceedings of the 6th Petroleum Geology Conference, 913-922. London: Geological Society.

Larsen, M., Hamberg, L., Olaussen, S. \& Stemmerik, L. 1996: Cretaceous-Tertiary pre-drift sediments of the Kangerlussuaq area, southern East Greenland. Bulletin Grønlands Geologiske Undersøgelse 172, 37-41. 
Larsen, M., Hamberg, L., Olaussen, S., Preuss, T. \& Stemmerik, L. 1999a: Sandstone wedges of the Cretaceous - Lower Tertiary Kangerlussuaq basin, East Greenland - outcrop analogues to the offshore North Atlantic. In: Fleet, A.J. \& Boldy, S.A.R. (eds): Petroleum geology of Northwest Europe: Proceedings of the 5th conference, 337-348. London: Geological Society.

Larsen, M., Hamberg, L., Olaussen, S., Nørgaard-Pedersen, N. \& Stemmerik, L. 1999b: Basin evolution in southern East Greenland: an outcrop analogue for Cretaceous-Paleogene basins in the North Atlantic volcanic margins. AAPG Bulletin 83, 12361261.

Larsen, M., Bjerager, M., Nedkvitne, T., Olaussen, S. \& Preuss, T. 2001: Pre-basaltic sediments (Aptian-Paleocene) of the Kangerlussuaq Basin, southern East Greenland. Geology of Greenland Survey Bulletin 189, 99-106.

Larsen, M., Heilmann-Clausen, C., Piasecki, S. \& Stemmerik, L. 2005: At the edge of a new ocean: post-volcanic evolution of the Palaeogene Kap Dalton Group, East Greenland. In: Doré, A.G. \& Vining, B.A. (eds): Petroleum geology: North-West Europe and global perspectives. Proceedings of the 6th Petroleum Geology Conference, 923-932. London: Geological Society.

Larsen, M., Knudsen, C., Frei, D., Frei, M., Rasmussen, T. \& Whitham, A.G. 2006: East Greenland and Faroe-Shetland sediment provenance and Palaeogene sand dispersal systems. Geological Survey of Denmark and Greenland Bulletin 10, 29-32.

Larsen, P.-H., Stemmerik, L., Nielsen, T.F.D. \& Rex, D.C. 1990: Lamprophyre dykes in Revdal, Scoresby Land, East Greenland: conflicting field observations and K-Ar determinations. Bulletin of the Geological Society of Denmark 38, 1-9.

Larsen, R.B. \& Tegner, C. 2006: Pressure conditions for the solidification of the Skaergaard intrusion: eruption of East Greenland flood basalts in less than 300,000 years. Lithos 92, 181-197, http://dx.doi.org/10.1016/j.lithos.2006.03.032

Lawver, L.A. \& Müller, R.D. 1994: Iceland hot-spot track. Geology 22, 311-314.

Layne, G.D., Rucklidge, J.C. \& Brooks, C.K. 1982: Astrophyllite from Kangerdlugssuaq, East Greenland. Mineralogical Magazine 45, 149-156.

Leeman, W.P., Dasch, E.J. \& Kays, M.A. 1976: ${ }^{207} \mathrm{~Pb} /{ }^{206} \mathrm{~Pb}$ wholerock age of gneisses from the Kangerdlugssuaq area, eastern Greenland. Nature 263, 469-471.

Lenoir, X., Féraud, G. \& Geoffroy, L. 2003: High-rate flexure of the East Greenland volcanic margin: constraints from ${ }^{40} \mathrm{Ar} /{ }^{39} \mathrm{Ar}$ dating of basaltic dykes. Earth and Planetary Science Letters 214, 515-528.

Levi, B.G. 1998: New measurements constrain models of mantle upwelling along a midocean ridge. Physics Today 51, 17-19.

Lovell, B. 2010: A pulse in the planet: regional control of high-frequency changes in relative sea level by mantle convection. Journal of the Geological Society (London) 167, 637-648, http://dx.doi. org/10.1144/0016-76492009-127

Lundstrom, C. 2009: Layered intrusion formation by top down thermal migration zone refining. EOS Transactions, American Geophysical Union 90, Fall Meeting Supplement, Abstract V14A-01.
Maaløe, S. 1976: The zoned plagioclase of the Skaergaard intrusion, East Greenland. Journal of Petrology 17, 318-419.

McBirney, A.R. 1997: The Skaergaard intrusion. In: Cawthorn, R.G. (ed.): Layered intrusions, 147-180 Amsterdam: Elsevier.

McBirney, A.R. \& Nakamura, Y. 1974: Immiscibility in late-stage magmas of the Skaergaard intrusion. Carnegie Institution Washington, Yearbook 73, 348-352.

McBirney, A.R. \& Naslund, H.R. 1990: The differentiation of the Skaergaard intrusion. A discussion of R.H. Hunter and R.S.J. Sparks. (Contributions to Mineralogy and Petrology 95: 451461). Contributions to Mineralogy and Petrology 104, 235-240.

McBirney, A.R. \& Noyes, R.M. 1979: Crystallization and layering of the Skaergaard intrusion. Journal of Petrology 20, 487-554.

McBirney, A.R. \& Sonnenthal, E.L. 1990: Metasomatic replacement in the Skærgaard intrusion, East Greenland: Preliminary observations. Chemical Geology 88, 245-260.

McBirney, A.R., White, C.M. \& Boudreau, A.E. 1990: Spontaneous development of concentric layering in a solidified siliceous dike, East Greenland. Earth Science Reviews 29, 321-330.

Macdonald, K.C., Scheirer, D.S. \& Carbotte, S.M. 1991: Midocean ridges: discontinuities, segments and giant cracks. Science 253, 986-994, http://dx.doi.org/10.1126/science.253.5023.986

Mckenzie, D. 2011: Compaction and crystallization in magma chambers: towards a model of the Skaergaard intrusion. Journal of Petrology 52, 905-930, http://dx.doi.org/10.1093/Petrology/ Egr009

Manning, C.E. \& Bird, D.K. 1986: Hydrothermal clinopyroxenes of the Skaergaard intrusion. Contributions to Mineralogy and Petrology 92, 437-447.

Manning, C.E. \& Bird, D.K. 1991: Porosity evolution and fluid flow in the basalts of the Skaergaard magma-hydrothermal system, East Greenland. American Journal of Science 291, 201-257.

Manning, C.E. \& Bird, D.K. 1995: Porosity, permeability, and basalt metamorphism. In: Schiffman, P. \& Day, H.W. (eds): Lowgrade metamorphism of mafic rocks. Geological Society of America Special Paper 296, 123-140.

Manning, C.E., Ingebritsen, S.E. \& Bird, D.K. 1993: Missing mineral zones in contact metamorphosed basalts. American Journal of Science 293, 894-938.

Marsh, J.S. 1973: Relationships between transform directions and alkaline igneous rock lineaments in Africa and South America. Earth and Planetary Science Letters 18, 317-323.

Marsh, J.S. 2010: The geochemistry and evolution of Palaeogene phonolites, central Namibia. Lithos 117, 149-160.

Marty, B., Upton, B.G.J. \& Ellam, R.M. 1998: Helium isotopes in early Tertiary basalts, northeast Greenland: evidence for $58 \mathrm{Ma}$ plume activity in the North Atlantic - Iceland volcanic province. Geology 26, 407-410.

Mathiesen, A., Bidstrup, T. \& Christiansen, F.G. 2000: Denudation and uplift history of the Jameson Land basin, East Greenland - constrained from maturity and fission track data. Global and Planetary Changes 24, 275-301.

Matthews, D.W. 1976: Post-cumulus disruption of the Lilloise intrusion, East Greenland. Geological Magazine 113, 287-296.

Matthews, D.W. 1979: A buried Tertiary pluton in East Greenland. 
Bulletin of the Geological Society of Denmark 28, 17-20.

Medvedev, S., Hartz, E.H. \& Podladchikov, Y.Y. 2008: Vertical motions of the fjord regions of central East Greenland: impact of glacial erosion, deposition, and isostasy. Geology 36, 539-542, http://dx.doi.org/10.1130/G24638A.1

Meighan, I.G. \& Gamble, J.A. 1972: Tertiary acid magmatism in N.E. Ireland. Nature, Physical Science 240, 183-184.

Meighan, I.G., McCormack, A.G., Gibson, D., Gamble, J.A. \& Graham, I.J. 1988: Rb-Sr isotopic determinations and the timing of Tertiary central complex magmatism in NE Ireland. In: Morton, A.C. \& Parsons, L.M. (eds): Early Tertiary volcanism and the opening of the NE Atlantic. Geological Society Special Publications (London) 39, 349-360.

Melt Seismic Team, The 1998: Imaging the deep seismic structure beneath a mid-ocean ridge: the Melt Experiment. Science 280, 1215-1218.

Menzies, M., Baker, J. \& Chazot, G. 2001: Cenozoic plume evolution and flood basalts in Yemen: a key to understanding older examples. In: Ernst, R.E., Buchan K.L. (eds): Mantle plumes: their identification through time. Geological Society of America Special Papers 352, 23-36.

Molnar, P. \& England, P. 1990: Late Cenozoic uplift of mountain ranges and global climate change: chicken or egg? Nature 346, $29-34$.

Momme, P. \& Wilson, R. 2002: The Kraemer Island macrodyke, East Greenland: solidification of a flood basalt conduit. Geological Magazine 139, 171-190.

Momme, P., Brooks, C.K., Tegner, C. \& Keays, R.R. 2002: The behaviour of platinum group elements in basalts from the East Greenland rifted margin. Contributions to Mineralogy and Petrology 143, 133-153.

Momme, P., Tegner C., Brooks, C.K. \& Keays, R.R. 2006: Twomelting regimes during flood basalt formation in East Greenland: combined REE and PGE modelling. Contributions to Mineralogy and Petrology 151, 88-100.

Morgan, W.J. 1971: Convection plumes in the mantle. Nature 230, 42-43.

Morse, S.A. 1990: The differentiation of the Skaergaard intrusion. A discussion of Hunter \& Sparks (Contributions to Mineralogy and Petrology 95: 451-461). Contributions to Mineralogy and Petrology 104, 240-244.

Mosar, J., Eide, E.A., Osmundsen, P.T., Sommaruga, A. \& Torsvik, T. 2002a: Greenland-Norway separation: a geodynamic model for the North Atlantic. Norwegian Journal of Geology 82, 281-298.

Mosar, J., Lewis, G. \& Torsvik, T.H. 2002b: North Atlantic seafloor spreading rates: implications for the Tertiary development of inversion structures of the Norwegian-Greenland Sea. Journal of the Geological Society (London) 159, 503-515.

Moseley, F. 1981: Methods in field geology. Chapter 18: Reconnaissance survey of the Lilloise igneous complex (Tertiary), East Greenland, 174-186 (also pp. 42-43). Oxford and San Francisco: Freeman.

Moy, D.J. \& Imber, J. 2009: A critical analysis of the structure and tectonic significance of rift-oblique lineaments ('transfer zones') in the Mesozoic-Cenozoic succession of the Faroe-Shetland Basin, NE Atlantic margin. Journal of the Geological Society (London) 166, 831-844, http://dx.doi.org/10.1144/0016-76492009-010

Myers, J.S. 1980: Structure of the coastal dyke swarm and associated plutonic intrusions of East Greenland. Earth and Planetary Science Letters 46, 407-418.

Myers, J.S., Gill, R.C.O., Rex, D.C. \& Charnley, N.R. 1993: The Kap Gustav Holm Tertiary plutonic centre, East Greenland. Journal of the Geological Society (London) 150, 259-276.

Naslund, H.R. 1980: Part II - An experimental study of liquid immiscibility in iron-bearing silicate melts, $347 \mathrm{pp}$. Unpublished $\mathrm{PhD}$ thesis, University of Oregon, Eugene, USA. Naslund, H.R. 1986: Disequilibrium partial melting and rheomorphic layer formation in the contact aureole of the Basistoppen sill, East Greenland. Contributions to Mineralogy and Petrology 93, 359-367.

Naslund, H.R. 1989: Petrology of the Basistoppen sill, East Greenland: a calculated magma differentiation trend. Journal of Petrology 30, 299-319.

Neuhoff, P.S., Watt, W.S., Bird, D.K. \& Pedersen, A.K. 1997: Timing and structural relations of regional zeolite zones in basalts of the East Greenland continental margin. Geology 25, 803-806.

Nevle, R.J., Brandriss, M.E., Bird, D.K., McWilliams, M.O. \& O'Neil, J.R. 1994: Tertiary plutons monitor climate change in East Greenland. Geology 22, 775-778.

Nielsen, T.F.D. 1975: Possible mechanism of continental breakup in the North Atlantic. Nature 253, 182-184.

Nielsen, T.F.D. 1978: The Tertiary dike swarms of the Kangerdlugssuaq area, East Greenland. An example of magmatic development during continental break-up. Contributions to Mineralogy and Petrology 67, 63-78.

Nielsen, T.F.D. 1979: The occurrence and formation of Ti-aegirine in peralkaline syenites: an example from the Tertiary ultramafic alkaline Gardiner complex, East Greenland. Contributions to Mineralogy and Petrology 69, 235-244.

Nielsen, T.F.D. 1980: The petrology of a melilitolite, melteigite, carbonatite and syenite ring dike system in the Gardiner complex, East Greenland, Lithos 13, 181-197.

Nielsen, T.F.D. 1981: The ultramafic cumulate series, Gardiner Complex, East Greenland. Cumulates in a shallow level magma chamber of a nephelinitic volcano. Contributions to Mineralogy and Petrology 76, 60-72.

Nielsen, T.F.D. 1987: Tertiary alkaline magmatism in East Greenland: a review. In: Fitton, J.G. \& Upton, B.G.J. (eds): Alkaline igneous rocks. Geological Society Special Publications (London) 30, 489-515.

Nielsen, T.F.D. 1989: Comments on "The Tertiary Kærven syenite complex, Kangerdlugssuaq, East Greenland: mineral chemistry and geochemistry" by P.M. Holm and N.-O. Prægel. Mineralogical Magazine 53, 642-646.

Nielsen, T.F.D. 1994: Alkaline dike swarms of the Gardiner Complex and the origins of ultramafic alkaline complexes. Geochemistry International 31, 37-56.

Nielsen, T.F.D. 2004: The shape and volume of the Skaergaard intrusion, Greenland: implications for mass balance and bulk composition. Journal of Petrology 45, 507-530. 
Nielsen, T.F.D. \& Brooks, C.K. 1981: The E. Greenland rifted continental margin: an examination of the coastal flexure. Journal of the Geological Society (London) 138, 559-568.

Nielsen, T.F.D. \& Brooks, C.K. 1991: Generation of nordmarkitic melts by melting of basement gneisses: the Astrophyllite Bay Complex, Kangerdlugssuaq. Bulletin of the Geological Society of Denmark 38, 161-164.

Nielsen, T.F.D. \& Brooks, C.K. 1995: Precious metals in magmas of East Greenland: factors important to the mineralization in the Skaergaard intrusion. Economic Geology 90, 1911-1917.

Nielsen, T.F.D. \& Buchardt, B. 1985: Sr-C-O isotopes in nephelinitic rocks and carbonatites, Gardiner complex, Tertiary of East Greenland. Chemical Geology 53, 207-217.

Nielsen, T.F.D. \& Holm, P.M. 1993: Nd and Sr isotope compositions from the Gardiner complex, East Greenland Tertiary province. Bulletin of the Geological Society of Denmark 40, 280-287.

Nielsen, T.F.D. \& Johnsen, O. 1978: Titaniferous clinohumite from the Gardiner Plateau complex, East Greenland. Mineralogical Magazine 42, 99-101.

Nielsen, T.F.D., Soper, N.J., Brooks, C.K., Faller, A.M., Higgins, A.C. \& Mathews, D.W. 1981: The pre-basaltic sediments and the Lower Basalts at Kangerdlugssuaq, East Greenland: their stratigraphy, lithology, palaeo-magnetism and petrology. Meddelelser om Grønland, Geoscience 6, 25 pp.

Nielsen, T.F.D., Solovova, I.P. \& Veksler, I.V. 1997: Parental melts of melilitolite and origin of alkaline carbonatite. Contributions to Mineralogy and Petrology 126, 331-344.

Nielsen, T.F.D., Tegner, C., Thy, P., Fonseca, A.K.M., Jakobsen, J.K., Kristensen, M., Simpson, J., Brooks, C.K., Kent, A., Peate, D. \& Lesher, C.E. 2000: Retrieval of PLATINOVA drill cores: a new Skaergaard initiative. EOS Transactions of the American Geophysical Union 81, Fall Meeting Supplement, 1366 only.

Nielsen, T.F.D., Hansen, H., Brooks, C.K., Lesher, C.E. and field parties 2001: The East Greenland continental margin, the Prinsen af Wales Bjerge and new Skaergaard intrusion initiatives. Geology of Greenland Survey Bulletin 189, 83-98.

Nielsen, T.F.D., Andersen, J.C.Ø. \& Brooks, C.K. 2005: The Platinova Reef of the Skaergaard intrusion. In: Mungall, J.E. (ed.): Exploration for platinum group element deposits. Mineralogical Association of Canada, Short Course Notes 35, 431-455.

Nielsen, T.F.D., Turkov, V.A., Solovova, I.P., Kogarko, L.N. \& Ryabchikov, I.D. 2006: A Hawaiian beginning for the Iceland plume: modelling of reconnaissance data for olivine-hosted melt inclusions in Palaeogene picrite lavas from East Greenland. Lithos 92, 83-104, http://dx.doi.org/10.1016/j.lithos.2006.03.038

Nielsen, T.K., Larsen, H.C. \& Hopper, J.R. 2002: Contrasting rifted margin styles south of Greenland: implications for mantle plume dynamics. Earth and Planetary Science Letters 200, 271-286.

Noble, R.H., Macintyre, R.M. \& Brown, P.E. 1988: Age constraints on Atlantic evolution: timing of magmatic activity along the E Greenland continental margin. In: Morton, A.C. \& Parson, L.M. (eds): Early Tertiary volcanism and the opening of the NE Atlantic. Geological Society Special Publications (London) 39, 201-204.
Noe-Nygaard, A. 1976: Tertiary igneous rocks between Shannon and Scoresby Sund, East Greenland. In: Esher, A. \& Watt, W.S. (eds): Geology of Greenland, 386-402. Copenhagen: Grønlands Geologiske Undersøgelse.

Noe-Nygaard, A. \& Pedersen, A.K. 1974a: Progressive chemical variation in a tholeiitic lava sequence at Kap Stosch, northern East Greenland. Bulletin of the Geological Society of Denmark 23, 175-190.

Noe-Nygaard, A. \& Pedersen, A.K. 1974b: Tertiary volcanic rocks from Bontekoe Island, East Greenland. Rapport Grønlands Geologiske Undersøgelse 116, 1-13.

Nøhr-Hansen, H. \& Piasecki, S. 2002: Paleocene sub-basaltic sediments on Savoia Halvø, East Greenland. Geology of Greenland Survey Bulletin 191, 111-116.

Nøhr-Hansen, H., Nielsen, L.H., Sheldon, E., Hovikoski, J. \& Alsen, P. 2011: Palaeogene deposits in North-East Greenland. Geological Survey of Denmark and Greenland Bulletin 23, 61-64.

Nordenskjöld, O. 1909: On the geology and physical geography of East Greenland. Meddelelser om Grønland 28, 153-284.

Norton, D. \& Taylor, H.P. 1979: Quantitative simulation of the hydrothermal systems of crystallizing magmas on the basis of transport theory and oxygen isotope data: an analysis of the Skaergaard intrusion. Journal of Petrology 20, 421-486.

Norton, D., Taylor Jr., H.P. \& Bird, D.K. 1984: The geometry and high-temperature brittle deformation of the Skaergaard intrusion. Journal of Geophysical Research 89B, 10,178-10,192.

Nunns, A.G. 1983a: Plate tectonic evolution of the GreenlandScotland ridge and surrounding regions. In: Bott, M.H.P. et al. (eds): Structure and development of the Greenland-Scotland Ridge: new methods and concepts, 11-29. New York: Plenum Press.

Nunns, A.G. 1983b: The structure and evolution of the Jan Mayen Ridge and surrounding regions. In: Watkins, J.S. \& Drake, C.L. (eds): Continental margin geology. AAPG Memoirs 34, 193 208.

Nutman, A.P., Kalsbeek, F. \& Friend, C.R.L. 2008: The Nagssugtoqidian orogen in South-East Greenland: evidence for Palaeoproterozoic collision and plate assembly. American Journal of Science 308, 529-572.

ODP Shipboard Scientific Party 1996: Exploring the volcanic rifted margins of the North Atlantic. EOS, Transactions of the American Geophysical Union 77(17), 165 \& 168.

O'Hara, M.J. \& Matthews, R.E. 1981: Geochemical evolution in an advancing, periodically replenished, periodically tapped, continuously fractionated magma chamber. Journal of the Geological Society (London) 138, 237-277.

Ohja, D.N. 1966: Petrology of the Kaerven layered intrusion, East Greenland. Journal of the Geochemical Society of India 1, 86112.

Olesen, O., Ebbing, J., Lundin, E., Mauring, E., Skilbrei, J.R., Torsvik, T.H., Hansen, E.K., Henningsen, T., Midbøe, P. \& Sand, M. 2007: An improved tectonic model for the Eocene opening of the Norwegian-Greenland Sea: use of modern magnetic data. Marine and Petroleum Geology 24, 53-66, http://dx.doi. org/10.1016/j.marpetgeo.2006.10.008 
Olsen, S.D. 2005: Petrogenesis of Bermuda's igneous basement: petrology and geochemistry of the 1972 and 1980 recovered dyke rocks, 254 pp. Unpublished MSc thesis, University of Copenhagen, Denmark.

Pankhurst, R.J., Beckinsale, R.D. \& Brooks, C.K. 1976: Strontium and oxygen isotope evidence relating to the petrogenesis of the Kangerdlugssuaq alkaline intrusion. East Greenland. Contributions to Mineralogy and Petrology 54, 17-42.

Passey, S.R. \& Jolley, D.W. 2009 (for 2008): A revised lithostratigraphic nomenclature for the Palaeogene Faroe Islands Basalt Group, NE Atlantic Ocean. Earth and Environmental Science Transactions of the Royal Society of Edinburgh 99, 127-158, http://dx.doi.org/10.1017/S1755691009008044

Pearson, D.G., Emeleus, C.H. \& Kelley, S.P. 1996: Precise 40Ar/39Ar age for the initiation of Palaeogene volcanism in the Inner Hebrides and its regional significance. Journal of the Geological Society (London) 153, 815-818.

Pearson, D.G., Hamilton, M.A., Thompson, R.N. \& Emeleus, C.H. 1999: High precision U-Pb zircon dating of British Tertiary Volcanic Province basic central complexes and their constraints on lava eruption ages and lithospheric thinning. In: Jolley, D. \& Bell, B. (eds): The North Atlantic Igneous Province: magmatic controls on sedimentation. Abstracts, 21 only.

Peate, D.W. 1997: The Paraná-Etendeka Province. In: Mahoney, J.J. \& Coffin, M.F. (eds): Large igneous provinces. Continental, oceanic, and planetary flood volcanism. American Geophysical Union Monograph 100, 217-246.

Peate, D.W. \& Stecher, O. 2003: Pb isotope evidence for contributions from different Iceland mantle components to Palaeogene East Greenland flood basalts. Lithos 67, 39-52, http://dx.doi. org/10.1016/S0024-4937(02)00250-5

Peate, D.W., Baker, J.A., Blichert-Toft, J., Hilton, D.R., Storey, M., Kent, A.J.R., Brooks, C.K., Hansen, H., Pedersen, A.K. \& Duncan, R.A. 2003: The Prinsen af Wales Bjerge Formation lavas, East Greenland: the transition from tholeiitic to alkalic magmatism during the final stages of Tertiary continental break-up. Journal of Petrology 44, 279-304.

Peate, D.W., Barker, A.K., Riishuus, M.S. \& Andreasen, R. 2008: Temporal variations in crustal assimilation of magma suites in the East Greenland flood basalt province: tracking the evolution of magmatic plumbing systems. Lithos 102, 179-197, http:// dx.doi.org/10.1016/j.lithos.2007.08.009

Peate, I.U., Larsen, M. \& Lesher, C.E. 2003: The transition from sedimentation to flood volcanism in the Kangerlussuaq Basin, East Greenland: basaltic pyroclastic volcanism during initial Palaeogene continental break-up. Journal of the Geological Society (London) 160, 759-772, http://dx.doi.org/10.1144/0016-764902-071

Pedersen, A.K., Watt, M., Watt, W.S. \& Larsen, L.M. 1997: Structure and stratigraphy of the early Tertiary basalts of the Blosseville Kyst, East Greenland. Journal of the Geological Society (London) $154,565-570$.

Perchiazzi, N., McDonald, A.M., Gault, R.A., Johnsen, O. \& Merlino, S. 2000: The crystal structure of normandite and its crystalchemical relationships with låvenite. The Canadian Mineralogist 38, 641-648, http://dx.doi.org/10.2113/gscanmin.38.3.641
Petersen, T.S. 1977: Aputitêq lagdelte intrusioner, Østgrønland. Unpublished MSc thesis, University of Copenhagen, Denmark.

Poore, H., White, N. \& Maclennan, J. 2011: Ocean circulation and mantle melting controlled by radial flow of hot pulses in the Iceland plume. Nature 4, 558-561, http://dx.doi.org/10.1038/ NGEO1161

Prægel, N.-O. \& Holm, P.M. 2001: Replenishment episodes and crustal assimilation in the development of an early Tertiary magma chamber, East Greenland: evidence from layered cumulates of the Kælvegletscher ultramafic complex, Kangerlussuaq. Mineralogy and Petrology 73, 279-304.

Price, S., Brodie, J., Whitham, A. \& Kent, R. 1992: Mid-Tertiary rifting and magmatism in the Traill $\varnothing$ region, East Greenland. Journal of the Geological Society (London) 154, 419-434.

Pringle, M. \& Hardarson, B. 2000: The 10 m.y. rift cycles in Iceland driven by distance from hotspot, not pulsating plume. EOS Transactions of the American Geophysical Union, Fall Meeting Supplement, 1306.

Ravn, J.P.J. 1904: The Tertiary fauna at Kap Dalton in East Greenland. Meddelelser om Grønland 29, 95-140.

Redfield, T.F. 2010: On apatite fission track dating and the Tertiary evolution of West Greenland topography. Journal of the Geological Society (London) 167, 261-271, http://dx.doi. org/10.1144/0016-76492009-036

Rex, D.C., Gledhill, A.R., Brooks, C.K. \& Steenfelt, A. 1979: Radiometric ages of Tertiary salic intrusions near Kong Oscars Fjord, East Greenland. Rapport Grønlands Geologiske Undersøgelse 95, 106-109.

Richards, M.A., Duncan, R.A. \& Courtillot, V. 1989: Flood basalts and hotspot tracks: plume heads and tails. Science 246, 103-107.

Riishuus, M.S., Peate, D.W., Tegner, C., Wilson, J.R. Brooks, C.K. \& Waight, T.E. 2005: Petrogenesis of syenites at a rifted continental margin: origin, contamination and interaction of alkaline mafic and felsic magmas in the Astrophyllite Bay Complex, East Greenland. Contributions to Mineralogy and Petrology 149, 350-371, http://dx.doi.org/10.1007/s00410-005-0655-x

Riishuus, M.S., Peate, D.W., Tegner, C., Wilson, J.R., Brooks, C.K. \& Harris, C. 2006: Temporal evolution of a long-lived syenitic centre: the Kangerlussuaq Alkaline Complex, East Greenland. Lithos 92, 276-299.

Riishuus, M.S., Peate, D.W., Tegner, C., Wilson, J.R. \& Brooks, C.K. 2008: Petrogenesis of cogenetic silica-oversaturated and -undersaturated syenites by periodic recharge in a crustally contaminated magma chamber; the Kangerlussuaq intrusion, East Greenland. Journal of Petrology 49, 493-522.

Ritsema, J., Deuss, A., van Heijst, H.J. \& Woodhouse, J.H. 2011: S40RTS: a degree-40 shear-velocity model for the mantle from new Rayleigh wave dispersion, teleseismic traveltime and normalmode splitting function measurements. Geophysical Journal International 184, 1223-1236, http://dx.doi.org/10.1111/j.1365246X.2010.04884.x

Roest, W.R. \& Srivastava, S.P. 1989: Sea-floor spreading in the Labrador Sea: a new reconstruction. Geology 17, 1000-1003.

Rose, N.M. \& Bird, D.K. 1987: Prehnite-epidote phase relations in the Nordre Aputiteq and Kruuse Fjord layered gabbros, East 
Greenland. Journal of Petrology 28, 1193-1218.

Rose, N.M. \& Bird, D.K. 1994: Hydrothermally altered dolerite dikes in East Greenland: implications for Ca-metasomatism of basaltic protoliths. Contributions to Mineralogy and Petrology 116, 420-432.

Rosendahl, B.R. 1987: Architecture of continental rifts with special reference to East Africa. Annual Reviews of Earth and Planetary Sciences 15, 445-503.

Rosing, M.T., Lesher, C.E. \& Bird, D.K. 1989: Chemical modification of East Greenland Tertiary magmas by two-liquid interdiffusion. Geology 17, 626-629.

Rucklidge, J.C., Brooks, C.K. \& Nielsen, T.F.D. 1980: Petrology of the coastal dykes at Tugtilik, southern East Greenland. Meddelelser om Grønland, Geoscience 3, 17 pp.

Saunders, A.D., Fitton, J.G., Kerr, A.C., Norry, M.J. \& Kent, R.W. 1997: The North Atlantic igneous province. In: Mahoney, J.J. \& Coffin, M.F. (eds): Large igneous provinces: continental, oceanic and planetary volcanism. American Geophysical Union, Geophysical Monograph 100, 45-93.

Schaub, H.P. 1938: Zur Vulkanotektonik der Inseln Traill und Geographical Society (Nordostgrönland). Meddelelser om Grønland 114(1), 44 pp.

Schaub, H.P. 1942: Zur Geologie der Traill Insel (Nordost-Grönland). Ecologae Geologicae Helvetiae 35, 54 pp.

Schønwandt, H.K. 1988: Geology and geotectonic setting of cratonic porphyry molybdenum deposits in the North Atlantic region. In: Boissonnas, J. \& Omenetto, P. (eds): Mineral deposits within the European Community, 210-229. New York: Springer Verlag.

Scott, R.A., Ramsey, L.A., Jones, S.M., Sinclair, S. \& Pickles, C.S. 2005: Development of the Jan Mayen microcontinent by linked propagation and retreat of spreading ridges. In: Wandas, B. et al. (eds): Onshore-offshore relationships on the North Atlantic margin. Norwegian Petroleum Society Special Publication 12, 69-82.

Sheppard, S.M.F., Brown, P.E. \& Chambers, A.D. 1977: The Lilloise intrusion, East Greenland: hydrogen isotope evidence for the efflux of magmatic water into the contact metamorphic aureole. Contributions to Mineralogy and Petrology 63, 129-147.

Shu-Chuan Lin \& van Keken, P.E. 2005: Multiple volcanic episodes of flood basalts caused by thermochemical mantle plumes. Nature 436, 250-252, http://dx.doi.org/10.1038/nature03697

Sinton, C.W. \& Duncan, R.A. 1998: ${ }^{40} \mathrm{Ar}-{ }^{39} \mathrm{Ar}$ ages of lavas from the southeast Greenland margin, ODP Leg 152, and the Rockall Plateau, DSDP Leg 81. In: Saunders, A.D., Larsen, H.C. \& Wise, S.W.J. (eds): Proceedings of the Ocean Drilling Program, Scientific Results 152, 387-402, http://dx.doi.org/10.2973/odp. proc.sr.152.234.1998

Sinton, C.W., Hitchen, K. \& Duncan, R.A. 1998: ${ }^{40} \mathrm{Ar} /{ }^{39} \mathrm{Ar}$ geochronology of silicic and basic volcanic rocks on the margins of the North Atlantic. Geological Magazine 135, 161-170.

Smirnov, A.V. \& Tarduno, J. 2010: Co-location of eruption sites of the Siberian Traps and North Atlantic Igneous Province: implications for the nature of hotspots and mantle plumes. Earth and Planetary Science Letters 297, 687-690, http://dx.doi. org/10.1016/j.epsl.2010.07.023
Søager, N. \& Holm, P.M. 2009: Extended correlation of the Palaeogene Faroe Islands and East Greenland plateau basalts. Lithos 107, 205-215, http://dx.doi.org/10.1016/j.lithos.2008.10.002

Sobolev, A.V., Hofmann, A.W. \& Nikogosian, I.K. 2000: Recycled oceanic crust observed in 'ghost plagioclase' within the source of Mauna Loa lavas. Nature 404, 986-990.

Sonnenthal, E. 1992: Geochemistry of dendritic anorthosites and associated pegmatites in the Skaergaard intrusion, East Greenland: evidence for metasomatism by a chlorine-rich fluid. Journal of Volcanology and Geothermal Research 52, 209-230.

Soper, N.J. \& Costa, L.I. 1976: Palynological evidence for the age of Tertiary basalts and post-basaltic sediments at Kap Dalton, central East Greenland. Rapport Grønlands Geologiske Undersøgelse 80, 123-127.

Soper, N.J., Higgins, A.C., Downie, C., Matthews, D.W. \& Brown, P.E. 1976a: Late Cretaceous - Early Tertiary stratigraphy of the Kangerdlugssuaq area, East Greenland, and the age of the opening of the NE Atlantic. Journal of the Geological Society (London) 13, 85-104.

Soper, N.J., Downie, C., Higgins, A.C. \& Costa, L.I. 1976b: Biostratigraphic ages of Tertiary basalts on the East Greenland continental margin and their relationship to plate separation in the northeast Atlantic. Earth and Planetary Science Letters 32, 149-157.

Speckbacher, R., Behrmann, J.H., Nagel, T.J., Stipp, M. \& Devey, C.W. 2011: Splitting a continent: insights from submarine highresolution mapping of the Moresby Seamount detachment, offshore Papua New Guinea. Geology 39, 651-654, http://dx.doi. org/10.1130/G31931.1

Srivastava, S.P. \& Tapscott, C.R. 1986: Plate kinematics in the North Atlantic. In: Vogt, P.R. \& Tucholke, B.E. (eds): The western North Atlantic region. The geology of North America M, 379-404. Boulder, Colorado: Geological Society of America.

Stemmerik, L., Christiansen, F.G., Piasecki, S., Jordt, B., Marcussen, C. \& Nøhr-Hansen, H. 1993: Depositional history and petroleum geology of the Carboniferous to Cretaceous in the northern part of East Greenland. In: Vorren, T.O. et al. (eds): Arctic geology and petroleum potential. Norwegian Petroleum Society Special Publication 2, 67-87.

Stewart, B.W. \& DePaolo, D.J. 1990: Isotopic studies of processes in mafic magma chambers: II. The Skaergaard Intrusion, East Greenland. Contributions to Mineralogy and Petrology 104, 125-141.

Storey, M., Duncan, R.A., Pedersen, A.K., Larsen, L.M. \& Larsen, H.C. $1998:{ }^{40} \mathrm{Ar} /{ }^{39} \mathrm{Ar}$ geochronology of the West Greenland Tertiary volcanic province. Earth and Planetary Science Letters 160, 569-586.

Storey, M., Pedersen, A.K., Stecher, O., Bernstein, S., Larsen, H.C., Larsen, L.M., Baker, J.A. \& Duncan, R.A. 2004: Long-lived postbreakup magmatism along the East Greenland margin: evidence for shallow-mantle metasomatism by the Iceland plume. Geology 32, 173-176, http://dx.doi.org/10.1130/G19889.1

Storey, M., Duncan, R.A. \& Swisher III, C.C. 2007a: Paleocene thermal maximum and the opening of the northeast Atlantic. Science 316, 587-589. 
Storey, M., Duncan R.A. \& Tegner, C. 2007b: Timing and duration of volcanism in the North Atlantic Igneous Province: implications for geodynamics and links to the Iceland hotspot. Chemical Geology 241, 264-281, http://dx.doi.org/10.1016/j.chemgeo.2007.01.016

Stroncik, N.A. \& Devey, C.W. 2011: Recycled gabbro signature in hotspot magmas unveiled by plume-ridge interactions. Nature Geoscience 4, 393-397, http://dx.doi.org/10.1038/ngeo1121

Surlyk, F. 1990: Timing, style and sedimentary evolution of Late Palaeozoic - Mesozoic extensional basins in East Greenland. In: Hardman, R.F.P. \& Brooks, J. (eds): Tectonic events responsible for Britain's oil and gas reserves. Geological Society Special Publications (London) 55, 107-125.

Svensen, H., Planke, S., Malthe-Sørenssen, A., Jamtveit, B., Myklebust, R., Eidem, T. \& Rey, S.S. 2004: Release of methane from a volcanic basin as a mechanism for initial Eocene global warming. Nature 429, 542-545, http://dx.doi.org/10.1038/nature02566

Svensen, H., Planke, S. \& Corfu, F. 2010: Zircon dating ties NE Atlantic sill emplacement to initial Eocene global warming. Journal of the Geological Society (London) 167, 433-436, http:// dx.doi.org/10.1144/0016-76492009-125

Sykes, L.R. 1978: Intraplate seismicity, reactivation on pre-existing zones of weakness, alkaline magmatism, and other tectonism postdating continental fragmentation. Revues of Geophysics and Space Physics 16, 621-688.

Talwani, M. \& Eldholm, O. 1977: Evolution of the NorwegianGreenland Sea. Geological Society of America Bulletin 88, 969 -999 .

Tarling, D.H. 1967: The palaeomagnetic properties of some Tertiary lavas from East Greenland. Earth and Planetary Science Letters 3, 81-88.

Tarling, D.H., Hailwood, E.A. \& Løvlie, R. 1988: A palaeomagnetic study of lower Tertiary lavas in East Greenland and comparison with other lower Tertiary observations in the northern Atlantic. In: Morton, A.C. \& Parson, L.M. (eds): Early Tertiary volcanism and the opening of the NE Atlantic. Geological Society Special Publications (London) 39, 215-224.

Taylor Jr., H.P. \& Forester, R.W. 1979: An oxygen and hydrogen isotope study of the Skaergaard intrusion and its country rocks: a description of a 55 M.Y. old fossil hydrothermal system. Journal of Petrology 20, 355-419.

Tegner C. \& Duncan, R.A. 1999: ${ }^{40} \mathrm{Ar} /{ }^{39} \mathrm{Ar}$ chronology for the volcanic history of the southeast Greenland rifted margin. In: Larsen, H.C. et al. (eds): Proceedings of the Ocean Drilling Program, Scientific Results 163, 53-62, http://dx.doi.org/10.2973/ odp.proc.sr.163.108.1999

Tegner, C. \& Wilson, J.R. 1993: A late plutonic suite in the Kap Edvard Holm layered gabbro complex, East Greenland. Geological Magazine 130, 431-442.

Tegner, C. \& Wilson, J.R. 1995: Textures in a poikilitic olivine gabbro cumulate: evidence for supercooling. Mineralogy and Petrology 54, 161-173.

Tegner, C., Wilson, J.R. \& Brooks, C.K. 1993: Intraplutonic quench zones in the Kap Edvard Holm layered gabbro complex, East Greenland. Journal of Petrology 34, 681-710.
Tegner, C., Lesher, C.E., Larsen, L.M. \& Watt, W.S. 1998a: Evidence from the rare-earth-element record of mantle melting for cooling of the Tertiary Iceland plume. Nature 395, 591-594.

Tegner, C., Duncan, R.A., Bernstein, S., Brooks, C.K., Bird, D.K. \& Storey, M. 1998b: ${ }^{40} \mathrm{Ar} /{ }^{39} \mathrm{Ar}$ geochronology of Tertiary mafic intrusions along the East Greenland rifted margin: relation to flood basalts and the Iceland hotspot track. Earth and Planetary Science Letters 156, 75-88.

Tegner, C., Brooks, C.K., Duncan, R.A., Heister, L.E. \& Bernstein, S. 2008: ${ }^{40} \mathrm{Ar}-{ }^{39} \mathrm{Ar}$ ages of intrusions in East Greenland: rift-todrift transition over the Iceland hotspot. Lithos 101, 480-500.

Tegner, C., Thy, P., Holness, M.B., Jakobsen, J.K. \& Lesher, C.E. 2009: Differentiation and compaction in the Skaergaard intrusion. Journal of Petrology 50, 813-840, http://dx.doi. org/10.1093/Petrology/Egp020

Thirlwall, M.F., Upton, B.G.J. \& Jenkins, C. 1994: Interaction between continental lithosphere and the Iceland Plume $-\mathrm{Sr}-\mathrm{Nd}-\mathrm{Pb}$ isotope geochemistry of Tertiary basalts, N.E. Greenland. Journal of Petrology 35, 839-879.

Thirlwall, M.F., Gee, M.A.M., Taylor, R.N. \& Murton, B.J. 2004: Mantle components in Iceland and adjacent ridges investigated using double-spike $\mathrm{Pb}$ isotope ratios. Geochimica et Cosmochimica Acta 68, 361-386.

Thomassen, B. \& Krebs, J.D. 2001: Palaeogene gold- and silverbearing epithermal veins at Amdrup Fjord, southern East Greenland. Rapport Danmarks og Grønlands Geologiske Undersøgelse 2001/133, 78 pp.

Thomassen, B. \& Nielsen, T.F.D. 2006: The mineral potential of the East Greenland Palaeogene intrusions. Geology and Ore 6, February 2006, 12 pp.

Thomson, K., Green, P.E., Whitham, A.G., Price, S.P. \& Underhill, J.R. 1999: New constraints on the thermal history of NorthEast Greenland from apatite fission-track analysis. Bulletin of the Geological Society of America 111, 1054-1068.

Thrane, K., Connelly, J., Bizzaro, M., Meyer, B.S. \& The, L.-S. 2010: Origin of excess ${ }^{176} \mathrm{Hf}$ in meteorites. The Astrophyscal Journal 717, 861-867, http://dx.doi.org/10.1088/0004-637X/ $717 / 2 / 861$

Torske, T. \& Prestvik, T. 1991: Mesozoic detachment faulting between Greenland and Norway: inferences from Jan Mayen Fracture Zone system and associated alkalic volcanic rocks. Geology 19, 481-484.

Torsvik, T.H., Burke, K., Steinberger, B., Webb, S.J. \& Ashwal, L.D. 2010: Diamonds sampled by plumes from the core-mantle boundary. Nature 466, 352-357, http://dx.doi.org/10.1038/nature09216

Troll, V.R., Nicoll, G.R., Donaldson, C.H. \& Emeleus, H.C. 2008: Dating the onset of volcanism at the Rum Igneous Centre, NW Scotland. Journal of the Geological Society (London) 165, 651659, http://dx.doi.org/10.1144/0016-76492006-190

Trønnes, R.G., Planke, S., Sundvoll, B. \& Imsland, P. 1999: Recent volcanic rocks from Jan Mayen: low-degree melt fractions of enriched northeast Atlantic mantle. Journal of Geophysical Research 104, 7153-7168.

Tyrrell, G.W. 1932: The petrography of some Kainozoic igneous 
rocks, and of the Kap Parry igneous complex, East Greenland. Geological Magazine 69, 520-527.

Upton, B.G.J. 1988: History of igneous activity in the N. Atlantic borderlands. In: Morton, A.C. \& Parsons, L.M. (eds): Early Tertiary volcanism in the NE Atlantic. Geological Society Special Publications (London) 39, 429-453.

Upton, B.G.J., Emeleus, C.H. \& Hald, N. 1980: Tertiary volcanism in northern East Greenland: Gauss Halvø and Hold with Hope. Journal of the Geological Society (London) 137, 491-508.

Upton, B.G.J., Emeleus, C.H. \& Beckinsale, R.D. 1984a: Petrology of northern East Greenland Tertiary flood basalts: evidence from Hold with Hope and Wollaston Forland. Journal of Petrology 25, 151-184.

Upton, B.G.J., Emeleus, C.H., Beckinsale, R.D. \& Macintyre, R.M. 1984b: Myggbukta and Kap Broer Ruys: the most northerly of the East Greenland Tertiary igneous centres(?). Mineralogical Magazine 48, 323-343.

Upton, B.G.J., Emeleus, C.H., Rex, D.C. \& Thirlwall, M.F. 1995: Early Tertiary magmatism in NE Greenland. Journal of the Geological Society (London) 152, 959-964.

Vallier, T., Calk, L., Stax, R. \& Demant, A. 1998: Metamorphosed sedimentary (volcaniclastic?) rocks beneath Paleocene Basalt in hole 917a, East Greenland margin. In: Saunders, A.D., Larsen, H.C. \& Wise Jr., S.W. (eds): Proceedings of the Ocean Drilling Program, Scientific Results 152,129-144, http://dx.doi. org/10.2973/odp.proc.sr.152.206.1998

Vincent, E.A. 1953: Hornblende-lamprophyre dykes of basaltic parentage from the Skaergaard area, East Greenland. Quarterly Journal of the Geological Society (London) 109, 21-50.

Vink, G.E. 1984: A hotspot model for Iceland and the Vøring Plateau. Journal of Geophysical Research B89, 9949-9959.

Vogt, P.R. 1974: The Iceland phenomenon: imprints of a hotspot on the ocean crust, and implications for flow below the plates. In: Kristjansson, L. (ed.): Geodynamics of Iceland and the North Atlantic area, 105-126. Dordrecht: D. Reidel.

Vosgerau, H., Guarnieri, P., Weibel, R., Larsen, M., Dennehy, C., Sørensen, E.V. \& Knudsen, C. 2010: Study of a Palaeogene intrabasaltic sedimentary unit in southern East Greenland: from 3-D photography to micropetrography. Geological Survey of Denmark and Greenland Bulletin 20, 75-78.

Wager, L.R. 1934: Geological investigations in East Greenland. Part I: General geology from Angmagssalik to Kap Dalton. Meddelelser om Grønland 105(2), 46 pp.

Wager, L.R. 1935: Geological investigations in East Greenland. Part II: Geology of Kap Dalton. Meddelelser om Grønland 105(3), $32 \mathrm{pp}$.

Wager, L.R.1937: The Kangerdlugssuaq region of East Greenland. The Geographical Journal XC, 393-425.

Wager, L.R. 1947: Geological investigations in East Greenland. Part IV: The stratigraphy and tectonics of Knud Rasmussens Land and the Kangerdlugssuaq region. Meddelelser om Grønland 134(3), $64 \mathrm{pp}$.

Wager, L.R. 1965: The form and structure of the alkaline Kangerdlugssuaq intrusion, East Greenland. Mineralogical Magazine 34, 487-497.
Wager, L.R. \& Brown, G.M. 1968: Layered igneous rocks, 588 pp. Edinburgh \& London: Oliver \& Boyd.

Wager, L.R. \& Deer, W.A. 1938: A dyke swarm and crustal flexure in East Greenland. Geological Magazine 75, 39-46.

Wager, L.R. \& Deer, W.A. 1939: Geological investigations in East Greenland. Part III: The petrology of the Skaergaard intrusion, Kangerdlugssuaq, East Greenland. Meddelelser om Grønland 105(4), $352 \mathrm{pp}$.

Wager, L.R. \& Hamilton, E.I. 1964: Some radiometric rock ages and the problem of the southward continuation of the East Greenland Caledonian orogeny. Nature 204, 1079-1080.

Wager, L.R., Brown, G.M. \& Wadsworth, W.J. 1960: Types of igneous cumulates. Journal of Petrology 1, 73-85.

Waight, T.E. \& Lesher, C.E. 2010: Pb isotopes during crustal melting and magma mingling - a cautionary tale from the Miki Fjord macrodike, central east Greenland. Lithos 118, 191-201, http://dx.doi.org/10.1016/j.lithos.2010.04.012

Waight, T.E., Baker, J.A. \& Willigers, B. 2002: Rb isotope dilution analyses by MC-ICPMS using $\mathrm{Zr}$ to correct for mass fractionation: towards improved Rb-Sr geochronology. Chemical Geology 186, 99-116.

Walker, G.P.L. 1972: Compound and simple lava flows and flood basalts. Bulletin of Volcanology 35, 579-590.

Walsh, J.N., Beckinsale, R.D., Skelhorne, R.R. \& Thorpe, R.S. 1979: Geochemistry and petrogenesis of Tertiary granitic rocks from the Island of Mull, northwest Scotland. Contributions to Mineralogy and Petrology 71, 99-116.

Watkins, G. 1932a: The British Arctic Air Route Expedition. Geographical Journal LXXIX, 353-367.

Watkins, G. 1932b: The British Arctic Air Route Expedition. Geographical Journal LXXX, 466-472.

Watkins, G. 1932c: The British Arctic Air Route Expedition. Geografisk Tidskrift 35, 109-128.

Wei, W. 2003: Comment on paper 'Palaeogene time scale miscalculation: evidence from the dating of the North Atlantic Igneous province'. Geology 31, 467 only.

Wenk, E. 1961: Tertiary of Greenland. In: Raasch, G.O. (ed.): Geology of the Arctic 1, 278-284. Toronto: University of Toronto Press.

Werner, R., van den Bogaard, P., Lacasse, C. \& Schmincke H.-U. 1998: Chemical composition, age, and sources of volcaniclastic sediments from sites 917 and 918. In: Saunders, A.D., Larsen, H.C. \& Wise Jr., S.W. (eds): Proceedings of the Ocean Drilling Program, Scientific Results 152, 93-114, http://dx.doi. org/10.2973/odp.proc.sr.152.211.1998

Wernicke, B. \& Tilke, P.G. 1989: Extensional tectonic framework of the U.S. central Atlantic passive margin. In: Tankard, A.J. \& Balkwill, H.R. (eds): Extensional tectonics and stratigraphy of the North Atlantic margins. AAPG Memoir 46, 7-21.

Westerhold, T., Röhl, U., Laskar, J., Raffi, I., Bowles, J., Lourens, L.J. \& Zachos, J.C. 2007: On the duration of magnetochrons C24r and C25n and the timing of early Eocene global warming events: implications from the Ocean Drilling Program Leg 208 Walvis Ridge depth transect. Paleoceanography 22, 1-19, http:// dx.doi.org/10.1029/2006PA001322 
Westerhold, T., Röhl, U., McCarren, H.K. \& Zachos, J.C. 2009: Latest on the absolute age of the Paleocene-Eocene Thermal Maximum (PETM): new insights from exact stratigraphic position of key ash layers +19 and -17 . Earth and Planetary Science Letters 287, 412-419, http://dx.doi.org/10.1016/j.epsl.2009.08.027

White, C.M., Geist, D.J., Frost, C.D. \& Verwoerd, W.J. 1989: Petrology of the Vandfaldsdalen macrodike, Skaergaard region, East Greenland. Journal of Petrology 30, 271-299.

White, N. \& Lovell, B. 1997: Measuring the pulse of a plume with the sedimentary record. Nature 387, 888-891.

White, R.S. \& McKenzie, D.P. 1989: Magmatism at rift zones: the generation of volcanic continental margins and flood basalts. Journal of Geophysical Research 94, 7685-7729.

White, R.S. \& Smith, L.K. 2009: Crustal structure of the Hatton and the conjugate east Greenland rifted volcanic continental margins, NE Atlantic. Journal of Geophysical Research 114, B02305, 28 pp., http://dx.doi.org/10.1029/2008JB005856

White, R.S., Smith, L.K., Roberts, A.W., Christie, P.A.F., Kusznir, N.J. \& the rest of the iSIMM team 2008: Lower crustal intrusion on the North Atlantic continental margin. Nature 452, 460-465, http://dx.doi.org/10.1038/nature06687

Williams, H.R. \& Williams, R.A. 1977: Kimberlites and plate tectonics in West Africa. Nature 270, 507-508.

Wilson, J.T. 1963: Evidence from islands on the spreading of ocean floors. Nature 197, 536-538.

Wilson, J.T. 1966: Did the Atlantic close and then re-open? Nature 211, 676-681.
Wilson, M. 1993: Magmatic differentiation. Journal of the Geological Society (London) 150, 611-624.

Wittig, N., Pearson, D.G., Webb, M., Ottley, C.J., Irvine, G.J., Kopylova, M., Jensen, S.M. \& Nowell, G.M. 2008: Origin of cratonic lithospheric mantle roots: a geochemical study of peridotites from the North Atlantic craton, West Greenland. Earth and Planetary Science Letters 274, 24-33, http://dx.doi. org/10.1016/j.epsl.2008.06.034

Wolfe, C.J., Bjarnason., I. Th., VanDecar, J.C. \& Solomon, S.C. 1997: Seismic structure of the Icelandic mantle plume. Nature 385, 245-247.

Wolfe, C.J., Solomon, S.C., Laske, G., Collins, J.A., Detrick, R.S., Orcutt, J.A., Bercovici, D. \& Hauri E.H. 2009: Mantle shearwave velocity structure beneath the Hawaiian hot spot. Science 326,1388-1390, http://dx.doi.org/10.1126/science.1180165

Wotzlaw, J.F., Bindeman, I.N., Schaltegger, U., Brooks, C.K. \& Naslund, H.R. 2011: Petrologic significance of high-precision zircon U-Pb dates from the Skaergaard intrusive complex. Mineralogical Magazine 75, 2179 only.

Young, D.A. 2003: Mind over magma. The story of igneous petrology, 704 pp. Princeton: Princeton University Press.

Zolotukin, V.V. \& Al'mukhamedov, A.I. 1988: Traps of the Siberian platform. In: Macdougall, J.D. (ed.): Continental flood basalts, 273-310. Dordrecht: Kluwer Academic. 
Appendix. Compilation of selected ages from East Greenland ${ }^{\dagger}$

\begin{tabular}{|c|c|c|c|c|c|c|c|c|}
\hline \multirow{2}{*}{$\begin{array}{l}\text { Location and rock type } \\
\text { Kap Wandel, basaltic dyke }\end{array}$} & \multirow{2}{*}{$\begin{array}{l}\text { Method } \\
{ }^{40} \mathrm{Ar} /{ }^{39} \mathrm{Ar}\end{array}$} & \multirow{2}{*}{$\begin{array}{l}\text { Sample }^{\phi} \\
\text { JV370 }\end{array}$} & \multirow{3}{*}{$\begin{array}{l}\text { Material } \\
\text { plagioclase }\end{array}$} & \multicolumn{3}{|c|}{ Age (Ma) $\pm(M a)$} & \multicolumn{2}{|c|}{ Comment Reference } \\
\hline & & & & 51.4 & 0.7 & $2 \sigma$ & plateau & Lenoir et al. (2003) \\
\hline & ${ }^{40} \mathrm{Ar} /{ }^{39} \mathrm{Ar}$ & & & 46.2 & 17.0 & $2 \sigma$ & isochron & \\
\hline \multirow[t]{2}{*}{ Kap Wandel, basaltic dyke } & ${ }^{40} \mathrm{Ar} /{ }^{39} \mathrm{Ar}$ & JV371 & plagioclase & 54.3 & 2.2 & $2 \sigma$ & plateau & \\
\hline & ${ }^{40} \mathrm{Ar} /{ }^{39} \mathrm{Ar}$ & & & 52.8 & 2.5 & $2 \sigma$ & isochron & \\
\hline \multirow[t]{2}{*}{ Kap Wandel, basaltic dyke } & ${ }^{40} \mathrm{Ar} /{ }^{39} \mathrm{Ar}$ & JV418 & plagioclase & 54.3 & 1.9 & $2 \sigma$ & plateau & \\
\hline & ${ }^{40} \mathrm{Ar} /{ }^{39} \mathrm{Ar}$ & & & 54.4 & 0.8 & $2 \sigma$ & isochron & \\
\hline \multirow[t]{2}{*}{ Kap Wandel, basaltic dyke } & ${ }^{40} \mathrm{Ar} /{ }^{39} \mathrm{Ar}$ & JV419 & plagioclase & 54.1 & 1.4 & $2 \sigma$ & plateau & \\
\hline & ${ }^{40} \mathrm{Ar} /{ }^{39} \mathrm{Ar}$ & & & 43.1 & 7.6 & $2 \sigma$ & isochron & \\
\hline \multirow[t]{2}{*}{ Kap Gustav Holm, basaltic dyke } & ${ }^{40} \mathrm{Ar} /{ }^{39} \mathrm{Ar}$ & JV264 & biotite & 51.0 & 0.3 & $2 \sigma$ & plateau & \\
\hline & ${ }^{40} \mathrm{Ar} /{ }^{39} \mathrm{Ar}$ & & & 50.4 & 0.4 & $2 \sigma$ & isochron & \\
\hline \multirow[t]{2}{*}{ Kap Gustav Holm, basaltic dyke } & ${ }^{40} \mathrm{Ar} /{ }^{39} \mathrm{Ar}$ & JV276 & amphibole & 53.9 & 0.6 & $2 \sigma$ & plateau & \\
\hline & ${ }^{40} \mathrm{Ar} /{ }^{39} \mathrm{Ar}$ & & & 52.2 & 1.6 & $2 \sigma$ & isochron & \\
\hline \multirow[t]{2}{*}{ Kap Gustav Holm, basaltic dyke } & ${ }^{40} \mathrm{Ar} /{ }^{39} \mathrm{Ar}$ & JV509 & plagioclase & 54.7 & 1.5 & $2 \sigma$ & plateau & \\
\hline & ${ }^{40} \mathrm{Ar} /{ }^{39} \mathrm{Ar}$ & & & 47.0 & 11.8 & $2 \sigma$ & isochron & \\
\hline \multirow[t]{2}{*}{ Kap Gustav Holm, basaltic dyke } & ${ }^{40} \mathrm{Ar} /{ }^{39} \mathrm{Ar}$ & JV510 & plagioclase & 48.0 & 2.8 & $2 \sigma$ & plateau & \\
\hline & ${ }^{40} \mathrm{Ar} /{ }^{39} \mathrm{Ar}$ & & & 50.4 & 2.0 & $2 \sigma$ & isochron & \\
\hline \multirow{2}{*}{ Imilik gabbro II, dolerite dyke } & ${ }^{40} \mathrm{Ar} /{ }^{39} \mathrm{Ar}$ & 416745 & whole-rock & 54.7 & 0.9 & $1 \sigma$ & isochron & Tegner et al. (1998b) \\
\hline & ${ }^{40} \mathrm{Ar} /{ }^{39} \mathrm{Ar}$ & & & 56.2 & 0.6 & $1 \sigma^{*}$ & plateau & \\
\hline \multirow[t]{2}{*}{ Imilik gabbro III, wehrlite sill } & ${ }^{40} \mathrm{Ar} /{ }^{39} \mathrm{Ar}$ & 416822 & mica & 49.3 & 0.6 & $1 \sigma$ & isochron & \\
\hline & ${ }^{40} \mathrm{Ar} /{ }^{39} \mathrm{Ar}$ & & & 49.2 & 0.2 & $1 \sigma^{*}$ & plateau & \\
\hline \multirow[t]{2}{*}{ Imilik gabbro III, wehrlite sill } & ${ }^{40} \mathrm{Ar} /{ }^{39} \mathrm{Ar}$ & 416804 & mica & 49.8 & 1.2 & $1 \sigma^{*}$ & isochron & \\
\hline & ${ }^{40} \mathrm{Ar} /{ }^{39} \mathrm{Ar}$ & & & 52.1 & 0.6 & $1 \sigma$ & plateau & \\
\hline \multirow[t]{2}{*}{ Kruuse Fjord, gabbro pegmatite } & ${ }^{40} \mathrm{Ar} /{ }^{39} \mathrm{Ar}$ & 428702 & mica & 48.0 & 1.2 & $1 \sigma^{*}$ & isochron & \\
\hline & ${ }^{40} \mathrm{Ar} /{ }^{39} \mathrm{Ar}$ & & & 51.5 & 0.3 & $1 \sigma$ & plateau & \\
\hline Igtutarajik, gabbro pegmatite & ${ }^{40} \mathrm{Ar} /{ }^{39} \mathrm{Ar}$ & $\mathrm{I}-7$ & mica & 47.0 & 0.3 & $1 \sigma$ & isochron & \\
\hline & ${ }^{40} \mathrm{Ar} /{ }^{39} \mathrm{Ar}$ & & & 47.0 & 0.2 & $1 \sigma^{*}$ & plateau & \\
\hline Kap Edvard Holm, MLS wehrlite sill & ${ }^{40} \mathrm{Ar} /{ }^{39} \mathrm{Ar}$ & PCT-75 & mica & 48.0 & 0.8 & $1 \sigma$ & isochron & \\
\hline & ${ }^{40} \mathrm{Ar} /{ }^{39} \mathrm{Ar}$ & & & 47.3 & 0.3 & $1 \sigma^{*}$ & plateau & \\
\hline Kap Edvard Holm, LLS gabbro pegmatite & ${ }^{40} \mathrm{Ar} /{ }^{39} \mathrm{Ar}$ & $\mathrm{KEH} 302$ & amphibole & 48.5 & 0.4 & $1 \sigma$ & isochron & Same sample as Nevle et al. 1994) \\
\hline & ${ }^{40} \mathrm{Ar} /{ }^{39} \mathrm{Ar}$ & & & 48.8 & 0.2 & $1 \sigma^{*}$ & plateau & \\
\hline Lilloise intrusion, syenite vein & ${ }^{40} \mathrm{Ar} /{ }^{39} \mathrm{Ar}$ & CKB71-54C & amphibole & 50.2 & 1.0 & $1 \sigma$ & isochron & \\
\hline & ${ }^{40} \mathrm{Ar} /{ }^{39} \mathrm{Ar}$ & & & 50.0 & 0.4 & $1 \sigma^{*}$ & plateau & \\
\hline Sorgenfri sills, I.C. Jacobsen Fjord dolerite & ${ }^{40} \mathrm{Ar} /{ }^{39} \mathrm{Ar}$ & 40006 & whole-rock & 54.7 & 0.9 & $1 \sigma$ & isochron & \\
\hline & ${ }^{40} \mathrm{Ar} /{ }^{39} \mathrm{Ar}$ & & & 56.3 & 0.9 & $1 \sigma^{*}$ & plateau & \\
\hline Sorgenfri sills, Fairytale Valley dolerite & ${ }^{40} \mathrm{Ar} /{ }^{39} \mathrm{Ar}$ & 413907 & plagioclase & 56.2 & 1.1 & $1 \sigma$ & isochron & \\
\hline & ${ }^{40} \mathrm{Ar} /{ }^{39} \mathrm{Ar}$ & & & 56.0 & 0.4 & $1 \sigma^{*}$ & plateau & \\
\hline Nuuk diorite & ${ }^{40} \mathrm{Ar} /{ }^{39} \mathrm{Ar}$ & 312001 & biotite & 36.2 & 0.6 & $2 \sigma^{*}$ & isochron & Tegner et al. (2008) \\
\hline Ikâsangmît syenite intrusion & ${ }^{40} \mathrm{Ar} /{ }^{39} \mathrm{Ar}$ & 429360 & amphibole & 37.2 & 2.9 & $2 \sigma^{*}$ & isochron & \\
\hline Patulajivit gabbro complex & ${ }^{40} \mathrm{Ar} /{ }^{39} \mathrm{Ar}$ & $\mathrm{P}-175$ & biotite & 47.2 & 0.8 & $2 \sigma$ & total fusion & \\
\hline Søndre Aputitêq, gabbro-granite & ${ }^{40} \mathrm{Ar} /{ }^{39} \mathrm{Ar}$ & SA-1 & amphibole & 49.1 & 1.1 & $2 \sigma^{*}$ & plateau & \\
\hline Gardiner complex, ijolite dyke & ${ }^{40} \mathrm{Ar} /{ }^{39} \mathrm{Ar}$ & 29904 & biotite & 56.1 & 0.1 & $2 \sigma^{*}$ & isochron & \\
\hline Gardiner complex, melilitolite ring dyke & ${ }^{40} \mathrm{Ar} /{ }^{39} \mathrm{Ar}$ & 303825 & biotite & 54.3 & 1.2 & $2 \sigma^{*}$ & isochron & From Heister et al. (2001) \\
\hline Kangerlussuaq, biotite granite & ${ }^{40} \mathrm{Ar} /{ }^{39} \mathrm{Ar}$ & 333132 & biotite & 46.3 & 1.0 & $2 \sigma^{*}$ & isochron & From Heister et al. (2001) \\
\hline Kraemer Island, syenite & ${ }^{40} \mathrm{Ar} /{ }^{39} \mathrm{Ar}$ & NM27025 & biotite & 50.1 & 1.1 & $2 \sigma^{*}$ & isochron & \\
\hline Kangerdlugssuaq intrusion, syenite & ${ }^{40} \mathrm{Ar} /{ }^{39} \mathrm{Ar}$ & EG4583 & biotite & 50.8 & 1.1 & $2 \sigma^{*}$ & isochron & \\
\hline Snout Series syenite & ${ }^{40} \mathrm{Ar} /{ }^{39} \mathrm{Ar}$ & 312139 & biotite & 45.3 & 0.3 & $2 \sigma^{*}$ & isochron & \\
\hline Snout Series syenite & ${ }^{40} \mathrm{Ar} /{ }^{39} \mathrm{Ar}$ & $81-48$ & biotite & 46.7 & 0.5 & $2 \sigma^{*}$ & isochron & \\
\hline Kærven complex, gabbro & ${ }^{40} \mathrm{Ar} /{ }^{39} \mathrm{Ar}$ & 85659 & biotite & 54.8 & 1.4 & $2 \sigma^{*}$ & isochron & \\
\hline Kærven complex, alkali granite & ${ }^{40} \mathrm{Ar} /{ }^{39} \mathrm{Ar}$ & 40160 & amphibole & 52.8 & 1.3 & $2 \sigma^{*}$ & isochron & \\
\hline Wiedemann Fjord, lamprophyre dyke & ${ }^{40} \mathrm{Ar} /{ }^{39} \mathrm{Ar}$ & 429285 & amphibole & 41.5 & 0.9 & $2 \sigma^{*}$ & plateau & \\
\hline Ejnar Mikkelsen Fjeld, intrusion gabbro & ${ }^{40} \mathrm{Ar} /{ }^{39} \mathrm{Ar}$ & 457127 & biotite & 51.8 & 1.9 & $2 \sigma^{*}$ & isochron & \\
\hline Borgtinderne intrusion, syenite & ${ }^{40} \mathrm{Ar} /{ }^{39} \mathrm{Ar}$ & NM5133 & amphibole & 46.7 & 1.0 & $2 \sigma^{*}$ & plateau & \\
\hline Borgtinderne, basanite dyke & ${ }^{40} \mathrm{Ar} /{ }^{39} \mathrm{Ar}$ & 457163 & biotite & 36.6 & 0.5 & $2 \sigma^{*}$ & isochron & \\
\hline Kronborg Gletscher, nephelinite diatreme & ${ }^{40} \mathrm{Ar} /{ }^{39} \mathrm{Ar}$ & 436094 & biotite & 50.2 & 1.2 & $2 \sigma^{*}$ & isochron & \\
\hline
\end{tabular}

† This list attempts to include only the more reliable ages. K-Ar and fission track age data omitted, and Rb-Sr data largely omitted due to large uncertainties.

The reader is referred to the original sources for details of standards used etc.

$\Varangle$ Where no other letters are shown, the 6-digit sample number is prefixed by GGU (Geological Survey of Greenland).

* These ages preferred by the authors (choice between plateau and isochron ages). 


\section{Appendix. Compilation of selected ages from East Greenland (continued)}

\begin{tabular}{|c|c|c|c|c|c|c|c|c|}
\hline Location and rock type & Method & Sample & Material & Age $(\mathrm{Ma}) \pm$ & $\pm(\mathrm{Ma})$ & & Comment & Reference \\
\hline Kangerdlugssuaq intrusion & $\mathrm{Rb}-\mathrm{Sr}$ & & whole-rock & 50.0 & 1.9 & $2 \sigma$ & isochron & Pankhurst et al. (1976) \\
\hline Kangerdlugssuaq intrusion pulaskite & $\mathrm{Rb}-\mathrm{Sr}$ & & mineral & 49.9 & 1.0 & $2 \sigma$ & isochron & \\
\hline Jameson Land, basaltic dyke & ${ }^{40} \mathrm{Ar} /{ }^{39} \mathrm{Ar}$ & 407206 & plagioclase & 52.6 & 1.4 & $1 \sigma^{*} \mathrm{i}$ & isochron & Hald \& Tegner (2000) \\
\hline Jameson Land, basaltic sill & ${ }^{40} \mathrm{Ar} /{ }^{39} \mathrm{Ar}$ & 403031 & plagioclase & 52.0 & 1.2 & $1 \sigma^{*} \mathrm{i}$ & isochron & \\
\hline Malmbjerg & Re-Os & Malm-1 & molybdenite & e $\quad 25.8$ & 0.1 & $2 \sigma$ & - & Brooks et al. (2004) \\
\hline Flammefjeld & $\mathrm{Re}-\mathrm{Os}$ & 8215128 & molybdenite & e $\quad 39.7$ & 0.2 & $2 \sigma$ & - & \\
\hline Malmbjerg & ${ }^{40} \mathrm{Ar} /{ }^{39} \mathrm{Ar}$ & 467020 & biotite & 25.7 & 0.1 & $1 \sigma^{*}$ & plateau & \\
\hline Skaergaard intrusion & ${ }^{40} \mathrm{Ar} /{ }^{39} \mathrm{Ar}$ & SG61 & biotite & 55.4 & 0.0 & $2 \sigma$ & plateau & Hirschman et al. (1997) \\
\hline & ${ }^{40} \mathrm{Ar} /{ }^{39} \mathrm{Ar}$ & & & 55.4 & 0.7 & $2 \sigma i$ & isochron & \\
\hline Skaergaard intrusion & ${ }^{40} \mathrm{Ar} /{ }^{39} \mathrm{Ar}$ & SG61 & hornblende & 55.4 & 0.2 & $2 \sigma$ & plateau & \\
\hline & ${ }^{40} \mathrm{Ar} /{ }^{39} \mathrm{Ar}$ & & & 55.5 & 0.8 & $2 \sigma$ & isochron & \\
\hline Skaergaard intrusion & $\mathrm{U}-\mathrm{Pb}$ & & zircon & 55.59 & 0.1 & $2 \sigma$ & - & Hamilton \& Brooks (2004) \\
\hline Nansen Fjord Fm, lava & ${ }^{40} \mathrm{Ar} /{ }^{39} \mathrm{Ar}$ & 426296 & plagioclase & 57.7 & 0.5 & $2 \sigma$ & plateau & Storey et al. (2007b) \\
\hline & ${ }^{40} \mathrm{Ar} /{ }^{39} \mathrm{Ar}$ & & & 57.5 & 0.6 & $2 \sigma$ & isochron & \\
\hline Nansen Fjord Fm, lava & ${ }^{40} \mathrm{Ar} /{ }^{39} \mathrm{Ar}$ & 194021 & plagioclase & 59.2 & 1.4 & $2 \sigma$ & plateau & \\
\hline & ${ }^{40} \mathrm{Ar} /{ }^{39} \mathrm{Ar}$ & & & 56.8 & 2.3 & $2 \sigma$ & isochron & \\
\hline Skjoldungen, dyke (Fig. 1) & ${ }^{40} \mathrm{Ar} /{ }^{39} \mathrm{Ar}$ & 940211 & plagioclase & 61.4 & 1.0 & $2 \sigma$ & plateau & \\
\hline & ${ }^{40} \mathrm{Ar} /{ }^{39} \mathrm{Ar}$ & & & 61.1 & 1.6 & $2 \sigma$ & isochron & \\
\hline Tugtilik, carbonatite dyke & ${ }^{40} \mathrm{Ar} /{ }^{39} \mathrm{Ar}$ & 417150 & biotite & 58.3 & 0.9 & $2 \sigma$ & plateau & \\
\hline & ${ }^{40} \mathrm{Ar} /{ }^{39} \mathrm{Ar}$ & & & 58.1 & 1.0 & $2 \sigma$ & isochron & \\
\hline Tugtilik, carbonatite dyke & ${ }^{40} \mathrm{Ar} /{ }^{39} \mathrm{Ar}$ & 417151 & biotite & 58.3 & 0.9 & $2 \sigma$ & plateau & \\
\hline & ${ }^{40} \mathrm{Ar} /{ }^{39} \mathrm{Ar}$ & & & 57.5 & 1.2 & $2 \sigma$ & isochron & \\
\hline Skrænterne Fm (top), lava & ${ }^{40} \mathrm{Ar} /{ }^{39} \mathrm{Ar}$ & 412251 & whole-rock & 55.1 & 0.5 & $2 \sigma$ & plateau & \\
\hline & ${ }^{40} \mathrm{Ar} /{ }^{39} \mathrm{Ar}$ & & & 55.1 & 0.8 & $2 \sigma$ & isochron & \\
\hline Skrænterne Fm, lava & ${ }^{40} \mathrm{Ar} /{ }^{39} \mathrm{Ar}$ & 421564 & sanidine & 55.0 & 0.4 & $2 \sigma$ & plateau & \\
\hline & ${ }^{40} \mathrm{Ar} /{ }^{39} \mathrm{Ar}$ & & & 53.3 & 0.9 & $2 \sigma$ & isochron & \\
\hline Skrænterne Fm, lava & ${ }^{40} \mathrm{Ar} /{ }^{39} \mathrm{Ar}$ & 436194 & plagioclase & 54.9 & 0.9 & $2 \sigma$ & plateau & \\
\hline & ${ }^{40} \mathrm{Ar} /{ }^{39} \mathrm{Ar}$ & & & 56.1 & 4.5 & $2 \sigma$ & isochron & \\
\hline Rømer Fjord Fm, lava & ${ }^{40} \mathrm{Ar} /{ }^{39} \mathrm{Ar}$ & 436056 & plagioclase & 55.1 & 0.5 & $2 \sigma$ & plateau & \\
\hline & ${ }^{40} \mathrm{Ar} /{ }^{39} \mathrm{Ar}$ & & & 55.1 & 1.6 & $2 \sigma$ & isochron & \\
\hline Rømer Fjord Fm, lava & ${ }^{40} \mathrm{Ar} /{ }^{39} \mathrm{Ar}$ & 421522 & plagioclase & 55.4 & 0.5 & $2 \sigma$ & plateau & \\
\hline & ${ }^{40} \mathrm{Ar} /{ }^{39} \mathrm{Ar}$ & & & 55.5 & 1.6 & $2 \sigma$ & isochron & \\
\hline Milne Land Fm, lava & ${ }^{40} \mathrm{Ar} /{ }^{39} \mathrm{Ar}$ & 404107 & plagioclase & 56.1 & 0.5 & $2 \sigma$ & plateau & \\
\hline & ${ }^{40} \mathrm{Ar} /{ }^{39} \mathrm{Ar}$ & & & 56.1 & 0.7 & $2 \sigma$ & isochron & \\
\hline Urbjerget Fm, lava (Fig. 2) & ${ }^{40} \mathrm{Ar} /{ }^{39} \mathrm{Ar}$ & 436409 & plagioclase & 61.59 & 1.3 & $1 \sigma$ & plateau & Hansen (2002) \\
\hline & ${ }^{40} \mathrm{Ar} /{ }^{39} \mathrm{Ar}$ & & & 61.19 & 1.5 & $1 \sigma$ & isochron & \\
\hline Urbjerget Fm, lava & ${ }^{40} \mathrm{Ar} /{ }^{39} \mathrm{Ar}$ & 436411 & whole-rock & 60.97 & 1.1 & $1 \sigma$ & plateau & \\
\hline & ${ }^{40} \mathrm{Ar} /{ }^{39} \mathrm{Ar}$ & & & 59.58 & 1.7 & $1 \sigma$ & isochron & \\
\hline Milne Land Fm, lava & ${ }^{40} \mathrm{Ar} /{ }^{39} \mathrm{Ar}$ & 436412 & whole-rock & 56.72 & 1.0 & $1 \sigma$ & plateau & \\
\hline Milne Land Fm, lava & ${ }^{40} \mathrm{Ar} /{ }^{39} \mathrm{Ar}$ & 436430 & whole-rock & 56.74 & 1.1 & $1 \sigma$ & plateau & \\
\hline & ${ }^{40} \mathrm{Ar} /{ }^{39} \mathrm{Ar}$ & & & 56.93 & 2.4 & $1 \sigma$ & isochron & \\
\hline Milne Land Fm, lava & ${ }^{40} \mathrm{Ar} /{ }^{39} \mathrm{Ar}$ & 436449 & plagioclase & 56.70 & 1.7 & $1 \sigma$ & plateau & \\
\hline & ${ }^{40} \mathrm{Ar} /{ }^{39} \mathrm{Ar}$ & & & 56.36 & 1.8 & $1 \sigma$ & isochron & \\
\hline Milne Land Fm, lava & ${ }^{40} \mathrm{Ar} /{ }^{39} \mathrm{Ar}$ & 436458 & plagioclase & 54.93 & 1.6 & $1 \sigma$ & plateau & \\
\hline & ${ }^{40} \mathrm{Ar} /{ }^{39} \mathrm{Ar}$ & & & 54.79 & 2.7 & $1 \sigma$ & isochron & \\
\hline Prinsen afWales Fm, pegmatite & ${ }^{40} \mathrm{Ar} /{ }^{39} \mathrm{Ar}$ & 436231 & plagioclase & 54.88 & 1.0 & $1 \sigma$ & plateau & Peate et al. (2003) \\
\hline & ${ }^{40} \mathrm{Ar} /{ }^{39} \mathrm{Ar}$ & & & 55.07 & 1.1 & $1 \sigma$ & isochron & \\
\hline Lindsay Nunatak, lava (Fig. 2) & ${ }^{40} \mathrm{Ar} /{ }^{39} \mathrm{Ar}$ & 436223 & whole-rock & 53.08 & 1.2 & $1 \sigma$ & plateau & \\
\hline & ${ }^{40} \mathrm{Ar} /{ }^{39} \mathrm{Ar}$ & & & 52.52 & 1.1 & $1 \sigma$ & isochron & \\
\hline
\end{tabular}

¿ Where no other letters are shown, the 6-digit sample number is prefixed by GGU (Geological Survey of Greenland).

* These ages preferred by the authors (choice between plateau and isochron ages). 
Appendix. Compilation of selected ages from East Greenland (continued)

\begin{tabular}{|c|c|c|c|c|c|c|c|c|}
\hline \multirow{2}{*}{$\begin{array}{l}\text { Location and rock type } \\
\text { Kap Brewster, lava (all from same flow) }\end{array}$} & \multirow{2}{*}{$\begin{array}{l}\text { Method } \\
{ }^{40} \mathrm{Ar} /{ }^{39} \mathrm{Ar}\end{array}$} & \multirow{2}{*}{$\begin{array}{l}\text { Sample }^{\zeta} \\
\text { EG7147 }\end{array}$} & \multirow{2}{*}{$\begin{array}{l}\text { Material } \\
\text { whole-rock }\end{array}$} & \multicolumn{3}{|c|}{ Age $(M a) \pm(M a)$} & \multicolumn{2}{|c|}{ Comment Reference } \\
\hline & & & & 54.1 & 4.2 & $2 \sigma$ & plateau & Hansen et al. (1995) \\
\hline & ${ }^{40} \mathrm{Ar} /{ }^{39} \mathrm{Ar}$ & & & 55.0 & 16.0 & $2 \sigma$ & isochron & \\
\hline & ${ }^{40} \mathrm{Ar} /{ }^{39} \mathrm{Ar}$ & EG7148 & whole-rock & 57.8 & 4.5 & $2 \sigma$ & plateau & \\
\hline & ${ }^{40} \mathrm{Ar} /{ }^{39} \mathrm{Ar}$ & & & 51.0 & 9.0 & $2 \sigma$ & isochron & \\
\hline & ${ }^{40} \mathrm{Ar} /{ }^{39} \mathrm{Ar}$ & EG7149 & whole-rock & 56.9 & 5.2 & $2 \sigma$ & plateau & \\
\hline & ${ }^{40} \mathrm{Ar} /{ }^{39} \mathrm{Ar}$ & & & 56.0 & 10.0 & $2 \sigma$ & isochron & \\
\hline & ${ }^{40} \mathrm{Ar} /{ }^{39} \mathrm{Ar}$ & EG7150 & whole-rock & 57.7 & 3.4 & $2 \sigma$ & plateau & \\
\hline & ${ }^{40} \mathrm{Ar} /{ }^{39} \mathrm{Ar}$ & & & 54.0 & 6.0 & $2 \sigma$ & isochron & \\
\hline & ${ }^{40} \mathrm{Ar} /{ }^{39} \mathrm{Ar}$ & EG7151 & whole-rock & 54.5 & 4.1 & $2 \sigma$ & plateau & \\
\hline & ${ }^{40} \mathrm{Ar} /{ }^{39} \mathrm{Ar}$ & & & 55.0 & 8.0 & $2 \sigma$ & isochron & \\
\hline Kap Brewster lava: preferred age & ${ }^{40} \mathrm{Ar} /{ }^{39} \mathrm{Ar}$ & & & 56.7 & 4.3 & & & \\
\hline Skrænterne Fm, sanidine-bearing tuff & ${ }^{40} \mathrm{Ar} /{ }^{39} \mathrm{Ar}$ & 421564B & sanidine & 55.12 & 20.1 & $2 \sigma$ & mean $(n=15)$ & Storey et al. (2007a) \\
\hline Skrænterne Fm, sanidine-bearing tuff & ${ }^{40} \mathrm{Ar} /{ }^{39} \mathrm{Ar}$ & $421564 B$ & sanidine & 55.80 & 00.5 & & preferred & Heister et al. (2001) \\
\hline \multirow[t]{3}{*}{ Traill $\varnothing$, alkaline basaltic dyke } & ${ }^{40} \mathrm{Ar} /{ }^{39} \mathrm{Ar}$ & 4067 & whole-rock & 36.14 & 40.1 & $1 \sigma$ & plateau & Price et al. (1997) \\
\hline & ${ }^{40} \mathrm{Ar} /{ }^{39} \mathrm{Ar}$ & & & 36.87 & 70.2 & $1 \sigma$ & isochron & \\
\hline & ${ }^{40} \mathrm{Ar} /{ }^{39} \mathrm{Ar}$ & & & 37.14 & 40.2 & $1 \sigma$ & plateau & \\
\hline \multirow[t]{3}{*}{ Traill $\varnothing$, alkaline basaltic dyke } & ${ }^{40} \mathrm{Ar} /{ }^{39} \mathrm{Ar}$ & 4077 & whole-rock & 36.68 & 80.3 & $1 \sigma$ & plateau & \\
\hline & ${ }^{40} \mathrm{Ar} /{ }^{39} \mathrm{Ar}$ & & & 36.23 & 30.3 & $1 \sigma$ & isochron & \\
\hline & ${ }^{40} \mathrm{Ar} /{ }^{39} \mathrm{Ar}$ & & & 36.17 & 70.3 & $1 \sigma$ & plateau & \\
\hline \multirow[t]{2}{*}{ Traill $\varnothing$, tholeiitic basaltic dyke } & ${ }^{40} \mathrm{Ar} /{ }^{39} \mathrm{Ar}$ & 4058 & whole-rock & 52.00 & 02.0 & $1 \sigma$ & isochron & \\
\hline & ${ }^{40} \mathrm{Ar} /{ }^{39} \mathrm{Ar}$ & & & 56.00 & 05.0 & $1 \sigma$ & isochron & \\
\hline \multirow[t]{2}{*}{ Traill $\varnothing$, tholeiitic basaltic dyke } & ${ }^{40} \mathrm{Ar} /{ }^{39} \mathrm{Ar}$ & 4021 & whole-rock & 54.45 & 50.4 & $1 \sigma$ & plateau & \\
\hline & ${ }^{40} \mathrm{Ar} /{ }^{39} \mathrm{Ar}$ & & & 52.75 & 51.1 & $1 \sigma$ & plateau & \\
\hline \multirow[t]{3}{*}{ Traill $\varnothing$, tholeiitic basaltic dyke } & ${ }^{40} \mathrm{Ar} /{ }^{39} \mathrm{Ar}$ & 4105 & whole-rock & 53.50 & 01.5 & $1 \sigma$ & plateau & \\
\hline & ${ }^{40} \mathrm{Ar} /{ }^{39} \mathrm{Ar}$ & & & 55.80 & 00.9 & $1 \sigma$ & plateau & \\
\hline & ${ }^{40} \mathrm{Ar} /{ }^{39} \mathrm{Ar}$ & & & 53.20 & 01.2 & $1 \sigma$ & isochron & \\
\hline \multirow[t]{2}{*}{ Myggbukta complex, picrite sheet } & ${ }^{40} \mathrm{Ar} /{ }^{39} \mathrm{Ar}$ & 228139 & whole-rock & 32.7 & 1.2 & $1 \sigma$ & plateau & Upton et al. (1995)ף \\
\hline & ${ }^{40} \mathrm{Ar} /{ }^{39} \mathrm{Ar}$ & & & 32.0 & 5.0 & $1 \sigma$ & isochron & \\
\hline \multirow[t]{2}{*}{ Hold with Hope, Upper Series dyke } & ${ }^{40} \mathrm{Ar} /{ }^{39} \mathrm{Ar}$ & 228045 & whole-rock & 56.6 & 1.9 & $1 \sigma$ & plateau & \\
\hline & ${ }^{40} \mathrm{Ar} /{ }^{39} \mathrm{Ar}$ & & & 57.0 & 4.0 & $1 \sigma$ & isochron & \\
\hline \multirow[t]{2}{*}{ Hold with Hope, Upper Series dyke } & ${ }^{40} \mathrm{Ar} /{ }^{39} \mathrm{Ar}$ & 228058 & whole-rock & 56.7 & 0.7 & $1 \sigma$ & plateau & \\
\hline & ${ }^{40} \mathrm{Ar} /{ }^{39} \mathrm{Ar}$ & & & 51.0 & 6.0 & $1 \sigma$ & isochron & \\
\hline \multirow{2}{*}{$\begin{array}{r}\text { Hold with Hope, Upper Series anka- } \\
\text { ramitic lava }\end{array}$} & ${ }^{40} \mathrm{Ar} /{ }^{39} \mathrm{Ar}$ & 227959 & whole-rock & 53.4 & 3.9 & $1 \sigma$ & plateau & \\
\hline & ${ }^{40} \mathrm{Ar} /{ }^{39} \mathrm{Ar}$ & & & 53.0 & 6.0 & $1 \sigma$ & isochron & \\
\hline \multirow{2}{*}{$\begin{array}{l}\text { Hold with Hope, Lower Series nephe- } \\
\qquad \text { linitic lava }\end{array}$} & ${ }^{40} \mathrm{Ar} /{ }^{39} \mathrm{Ar}$ & 227933 & whole-rock & 58.7 & 1.4 & $1 \sigma$ & plateau & \\
\hline & ${ }^{40} \mathrm{Ar} /{ }^{39} \mathrm{Ar}$ & & & 60.0 & 12.0 & $1 \sigma$ & isochron & \\
\hline \multirow[t]{2}{*}{ ODP Leg 152-917A-23R-1A (basalt) } & ${ }^{40} \mathrm{Ar} /{ }^{39} \mathrm{Ar}$ & $31-36 \mathrm{~m}$ & whole-rock & 60.1 & 0.8 & $1 \sigma$ & plateau & Sinton \& Duncan (1998) \\
\hline & ${ }^{40} \mathrm{Ar} /{ }^{39} \mathrm{Ar}$ & & & 59.4 & 2.4 & $1 \sigma$ & isochron & \\
\hline ODP Leg 152-917A-23R-1A (basalt) & ${ }^{40} \mathrm{Ar} /{ }^{39} \mathrm{Ar}$ & $31-36 \mathrm{~m}$ & whole-rock & 60.8 & 1.0 & $1 \sigma$ & plateau & \\
\hline & ${ }^{40} \mathrm{Ar} /{ }^{39} \mathrm{Ar}$ & & & 60.6 & 1.8 & $1 \sigma$ & isochron & \\
\hline ODP Leg 152-917A-24R-1 & ${ }^{40} \mathrm{Ar} /{ }^{39} \mathrm{Ar}$ & 8-10 m & feldspar & 62.2 & 0.4 & $1 \sigma$ & plateau & \\
\hline & ${ }^{40} \mathrm{Ar} /{ }^{39} \mathrm{Ar}$ & & & 62.3 & 1.4 & $1 \sigma$ & isochron & \\
\hline ODP Leg 152-917A-40R-4 (basalt) & ${ }^{40} \mathrm{Ar} /{ }^{39} \mathrm{Ar}$ & $15-20 \mathrm{~m}$ & whole-rock & 60.7 & 1.2 & $1 \sigma$ & plateau & \\
\hline & ${ }^{40} \mathrm{Ar} /{ }^{39} \mathrm{Ar}$ & & & 60.3 & 4.2 & $1 \sigma$ & isochron & \\
\hline ODP Leg 152-917A-52R-1 (dacite) & ${ }^{40} \mathrm{Ar} /{ }^{39} \mathrm{Ar}$ & $45-49 \mathrm{~m}$ & whole-rock & 61.4 & 0.6 & $1 \sigma$ & plateau & \\
\hline & ${ }^{40} \mathrm{Ar} /{ }^{39} \mathrm{Ar}$ & & & 61.0 & 1.2 & $1 \sigma$ & isochron & \\
\hline ODP Leg 152-917A-69R-2 & ${ }^{40} \mathrm{Ar} /{ }^{39} \mathrm{Ar}$ & $43-53 \mathrm{~m}$ & plagioclase & 60.4 & 0.7 & $1 \sigma$ & plateau & \\
\hline & ${ }^{40} \mathrm{Ar} /{ }^{39} \mathrm{Ar}$ & & & 60.3 & 1.6 & $1 \sigma$ & isochron & \\
\hline ODP Leg 152-917A-83R-2 (basalt) & ${ }^{40} \mathrm{Ar} /{ }^{39} \mathrm{Ar}$ & $113-118 \mathrm{~m}$ & whole-rock & 68.2 & 1.6 & $1 \sigma$ & plateau & \\
\hline & ${ }^{40} \mathrm{Ar} /{ }^{39} \mathrm{Ar}$ & & & 63.3 & 1.2 & $1 \sigma$ & isochron & \\
\hline ODP Leg 152-917A-83R-3 (basalt) & ${ }^{40} \mathrm{Ar} /{ }^{39} \mathrm{Ar}$ & $46-50 \mathrm{~m}$ & whole-rock & 64.1 & 2.2 & $1 \sigma$ & plateau & \\
\hline & ${ }^{40} \mathrm{Ar} /{ }^{39} \mathrm{Ar}$ & & & 63.3 & 1.0 & $1 \sigma$ & isochron & \\
\hline ODP Leg 152-918D-94R-2 (basalt) & ${ }^{40} \mathrm{Ar} /{ }^{39} \mathrm{Ar}$ & $42-47 \mathrm{~cm}$ & whole-rock & 51.9 & 0.8 & $1 \sigma$ & plateau & \\
\hline & ${ }^{40} \mathrm{Ar} /{ }^{39} \mathrm{Ar}$ & & & 51.9 & 1.2 & $1 \sigma$ & isochron & \\
\hline
\end{tabular}

¿ Where no other letters are shown, the 6-digit sample number is prefixed by GGU (Geological Survey of Greenland).

* These ages preferred by the authors (choice between plateau and isochron ages).

I Information very sparse and with discrepancies between text and table, e.g. sample 228058 has $\pm 7.0 \mathrm{Ma}$ in table and $\pm 0.7 \mathrm{Ma}$ in text. 
Appendix. Compilation of selected ages from East Greenland (continued)

\begin{tabular}{|c|c|c|c|c|c|c|c|}
\hline \multirow{2}{*}{$\begin{array}{l}\text { Location and rock type } \\
\text { ODP Leg 163-988A-3R-2 }\end{array}$} & \multirow{2}{*}{$\begin{array}{l}\text { Method } \\
{ }^{40} \mathrm{Ar} /{ }^{39} \mathrm{Ar}\end{array}$} & Sample & \multirow{2}{*}{$\begin{array}{l}\text { Material } \\
\text { plagioclase }\end{array}$} & \multicolumn{2}{|c|}{ Age $(\mathrm{Ma}) \pm(\mathrm{Ma})$} & \multicolumn{2}{|c|}{ Comment Reference } \\
\hline & & - $70-76 \mathrm{~cm}$ & & 49.4 & $0.31 \sigma$ & plateau & Tegner \& Duncan (1999) \\
\hline & ${ }^{40} \mathrm{Ar} /{ }^{39} \mathrm{Ar}$ & & & 47.5 & $1.81 \sigma$ & isochron & \\
\hline \multirow[t]{2}{*}{ ODP Leg 163-988A-3R-3 (basalt) } & ${ }^{40} \mathrm{Ar} /{ }^{39} \mathrm{Ar}$ & - $17-22 \mathrm{~cm}$ & whole-rock & 49.4 & $0.51 \sigma$ & plateau & \\
\hline & ${ }^{40} \mathrm{Ar} /{ }^{39} \mathrm{Ar}$ & & & 49.8 & $1.21 \sigma$ & isochron & \\
\hline \multirow[t]{2}{*}{ ODP Leg 163-988A-3R-3 (basalt) } & ${ }^{40} \mathrm{Ar} /{ }^{39} \mathrm{Ar}$ & - $17-22 \mathrm{~cm}$ & whole-rock & 51.1 & $1.01 \sigma$ & plateau & \\
\hline & ${ }^{40} \mathrm{Ar} /{ }^{39} \mathrm{Ar}$ & & & 50.0 & $2.21 \sigma$ & isochron & \\
\hline \multirow[t]{2}{*}{ ODP Leg 163-988A-3R-3 (basalt) } & ${ }^{40} \mathrm{Ar} /{ }^{39} \mathrm{Ar}$ & - $17-22 \mathrm{~cm}$ & whole-rock & 49.7 & $0.31 \sigma$ & plateau & \\
\hline & ${ }^{40} \mathrm{Ar} /{ }^{39} \mathrm{Ar}$ & & & 47.3 & $1.61 \sigma$ & isochron & \\
\hline \multirow[t]{2}{*}{ ODP Leg 163-989B-4R-2 (basalt) } & ${ }^{40} \mathrm{Ar} /{ }^{39} \mathrm{Ar}$ & $102-110 \mathrm{~cm}$ & whole-rock & 57.1 & $1.41 \sigma$ & plateau & \\
\hline & ${ }^{40} \mathrm{Ar} /{ }^{39} \mathrm{Ar}$ & & & 54.1 & $1.21 \sigma$ & isochron & \\
\hline \multirow{2}{*}{ ODP Leg 163-989B-5R-2 (basalt) } & ${ }^{40} \mathrm{Ar} /{ }^{39} \mathrm{Ar}$ & - $28-33 \mathrm{~cm}$ & whole-rock & 57.1 & $1.41 \sigma$ & plateau & \\
\hline & ${ }^{40} \mathrm{Ar} /{ }^{39} \mathrm{Ar}$ & & & 57.9 & $3.81 \sigma$ & isochron & \\
\hline \multirow[t]{2}{*}{ ODP Leg 163-990A-3R-1 (basalt) } & ${ }^{40} \mathrm{Ar} /{ }^{39} \mathrm{Ar}$ & - $56-60 \mathrm{~cm}$ & whole-rock & 56.2 & $1.31 \sigma$ & plateau & \\
\hline & ${ }^{40} \mathrm{Ar} /{ }^{39} \mathrm{Ar}$ & & & 54.8 & $2.21 \sigma$ & isochron & \\
\hline \multirow[t]{2}{*}{ ODP Leg 163-990A-7R-2 (basalt) } & ${ }^{40} \mathrm{Ar} /{ }^{39} \mathrm{Ar}$ & - $50-56 \mathrm{~cm}$ & whole-rock & 55.4 & $0.71 \sigma$ & plateau & \\
\hline & ${ }^{40} \mathrm{Ar} /{ }^{39} \mathrm{Ar}$ & & & 55.1 & $0.71 \sigma$ & isochron & \\
\hline \multirow[t]{2}{*}{ ODP Leg 163-990A-16R-4 (basalt) } & ${ }^{40} \mathrm{Ar} /{ }^{39} \mathrm{Ar}$ & $7-11 \mathrm{~cm}$ & whole-rock & 56.0 & $0.91 \sigma$ & plateau & \\
\hline & ${ }^{40} \mathrm{Ar} /{ }^{39} \mathrm{Ar}$ & & & 55.0 & $1.01 \sigma$ & isochron & \\
\hline \multirow[t]{2}{*}{ ODP Leg 163-990A-17R-3 (basalt) } & ${ }^{40} \mathrm{Ar} /{ }^{39} \mathrm{Ar}$ & $104-109 \mathrm{~cm}$ & whole-rock & 55.5 & $2.21 \sigma$ & plateau & \\
\hline & ${ }^{40} \mathrm{Ar} /{ }^{39} \mathrm{Ar}$ & & & 54.8 & $2.31 \sigma$ & isochron & \\
\hline \multirow[t]{2}{*}{ ODP Leg 163-990A-19R-5 (basalt) } & ${ }^{40} \mathrm{Ar} /{ }^{39} \mathrm{Ar}$ & - $21-26 \mathrm{~cm}$ & whole-rock & 55.2 & $1.41 \sigma$ & plateau & \\
\hline & ${ }^{40} \mathrm{Ar} /{ }^{39} \mathrm{Ar}$ & & & 57.1 & $1.71 \sigma$ & isochron & \\
\hline ODP Leg 152-917A-24R-1 (tuff) & ${ }^{40} \mathrm{Ar} /{ }^{39} \mathrm{Ar}$ & $1-3 \mathrm{~cm}$ & feldspar & 66.9 & $0.12 \sigma$ & isochron & Werner et al. (1998) \\
\hline ODP Leg 152-917A-23R-3 (lapillistone) & ${ }^{40} \mathrm{Ar} /{ }^{39} \mathrm{Ar}$ & - $14-17 \mathrm{~cm}$ & feldspar & 60.6 & $0.22 \sigma$ & isochron & \\
\hline $\begin{array}{l}\text { ODP Leg 152-917A-53R-1 } \\
\text { (dacitic pyroclastic flow) }\end{array}$ & ${ }^{40} \mathrm{Ar} /{ }^{39} \mathrm{Ar}$ & - $0-115 \mathrm{~cm}$ & feldspar & 60.6 & $0.82 \sigma$ & isochron & \\
\hline ODP Leg 152-917A-23R-2 (tuff) & ${ }^{40} \mathrm{Ar} /{ }^{39} \mathrm{Ar}$ & $127-131 \mathrm{~cm}$ & feldspar & 60.6 & $0.22 \sigma$ & isochron & \\
\hline Kap Edvard Holm (KEH) (peridotite) & ${ }^{40} \mathrm{Ar} /{ }^{39} \mathrm{Ar}$ & - KEH406B & hornblende & 49.4 & $0.31 \sigma$ & isochron & Nevle et al. (1994) \\
\hline $\mathrm{KEH}$ (pegmatite) & ${ }^{40} \mathrm{Ar} /{ }^{39} \mathrm{Ar}$ & - KEH402A & hornblende & 49.7 & $0.31 \sigma$ & isochron & \\
\hline KEH (pegmatite pod in gabbro xenolith) & ${ }^{40} \mathrm{Ar} /{ }^{39} \mathrm{Ar}$ & KEH274F & hornblende & 49.7 & $0.41 \sigma$ & isochron & \\
\hline KEH (pegmatite pod in gabbro xenolith) & ${ }^{40} \mathrm{Ar} /{ }^{39} \mathrm{Ar}$ & KEH302 & hornblende & 49.4 & $0.31 \sigma$ & isochron & \\
\hline KEH (pegmatite pod in gabbro xenolith) & ${ }^{40} \mathrm{Ar} /{ }^{39} \mathrm{Ar}$ & KEH302 & phlogopite & 48.6 & $0.21 \sigma$ & isochron & \\
\hline KEH (pegmatite pod in gabbro xenolith) & ${ }^{40} \mathrm{Ar} /{ }^{39} \mathrm{Ar}$ & - KEH306A & phlogopite & 48.6 & $0.21 \sigma$ & isochron & \\
\hline KEH (pegmatite pod in gabbro xenolith) & ${ }^{40} \mathrm{Ar} /{ }^{39} \mathrm{Ar}$ & $\mathrm{K} 3 \mathrm{E}$ & hornblende & 42.1 & $0.51 \sigma$ & isochron & \\
\hline KEH (syenite) & ${ }^{40} \mathrm{Ar} /{ }^{39} \mathrm{Ar}$ & $\mathrm{KEH} 200$ & edenite & 44.3 & $0.91 \sigma$ & isochron & \\
\hline Nordre Aputitêq, miarolitic cavity in gabbro & ${ }^{40} \mathrm{Ar} /{ }^{39} \mathrm{Ar}$ & $\mathrm{A} 14 \mathrm{~A}$ & phlogopite & 48.1 & $0.21 \sigma$ & isochron & \\
\hline
\end{tabular}

